\title{
Technical Support Document: $50 \%$ Energy Savings for Quick-Service Restaurants
}

\author{
J Zhang \\ DA Zabrowski \\ DW Schrock \\ MD Lane \\ DR Fisher \\ A Livchak \\ RA Athalye \\ B Liu
}

September 2010

\section{Pacific Northwest}

NATIONAL LABORATORY

Proudly Operated by Battelle Since 1965 


\title{
DISCLAIMER
}

This report was prepared as an account of work sponsored by an agency of the United States Government. Neither the United States Government nor any agency thereof, nor Battelle Memorial Institute, nor any of their employees, makes any warranty, express or implied, or assumes any legal liability or responsibility for the accuracy, completeness, or usefulness of any information, apparatus, product, or process diselosed, or represents that its use would not infringe privately owned rights. Reference herein to any specific commercial product, process, or service by trade name, trademark, manufacturer, or otherwise does not necessarily constitute or imply its endorsement, recommendation, or favoring by the United States Government or any agency thereof, or Battelle Memorial Institute. The views and opinions of authors expressed herein do not necessarily state or reflect those of the United States Government or any agency thereof.

\author{
PACIFIC NORTHWEST NATIONAL LABORATORY \\ operated by \\ BATTELLE \\ for the \\ UNITED STATES DEPARTMENT OF ENERGY \\ under Contract DE-AC05-76RL01830
}

Printed in the United States of America

Available to DOE and DOE contractors from the

Office of Scientific and Technical Information,

P.O. Box 62, Oak Ridge, TN 37831-0062;

ph: (865) 576-8401

fax: (865) 576-5728

email: reports@adonis.osti.gov

\begin{abstract}
Available to the public from the National Technical Information Service, U.S. Department of Commerce, 5285 Port Royal Rd., Springfield, VA 22161 ph: (800) 553-6847$$
\text { fax: (703) 605-6900 }
$$

email: orders@ntis.fedworld.gov

online ordering: http://www.ntis.gov/ordering.htm
\end{abstract}

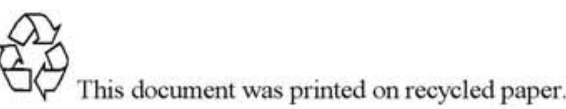

$(9 / 2003)$ 


\title{
Technical Support Document: 50\% Energy Savings for Quick-Service Restaurants
}

\author{
J Zhang \\ DA Zabrowski ${ }^{3}$ \\ DW Schrock ${ }^{1}$ \\ MD Lane ${ }^{2}$ \\ DR Fisher ${ }^{3}$ \\ RA Athalye \\ A Livchak ${ }^{1}$ \\ B Liu, Project Manager
}

September 2010

Prepared for

the U.S. Department of Energy

under Contract DE-AC05-76RL01830

Pacific Northwest National Laboratory

Richland, Washington 99352

\footnotetext{
${ }^{1}$ Mr. Derek Schrock and Dr. Andrey Livchak work for Halton Company in Scottsville, Kentucky.

${ }^{2}$ Mr. Michael Lane works for Seattle Lighting Design Lab in Seattle, Washington.

${ }^{3}$ Mr. Don Fisher and Mr. David Zabrowski work for Fisher-Nickel, inc., operator of Pacific Gas and Electric's Food Service Technology Center in San Ramon, California.
} 


\section{Executive Summary}

The work documented in this report was conducted by Pacific Northwest National Laboratory (PNNL) for the U.S. Department of Energy's Building Technologies Program (DOE/BTP). According to DOE, buildings account for over $40 \%$ of total energy use and over $70 \%$ of electricity use in the United States. To reduce building energy usage, DOE/BTP established a strategic goal to significantly improve the energy efficiency of new and existing commercial buildings across the nation.

In direct support of DOE's goal, the objective of this work is to develop a package of energy efficiency measures (EEMs) that demonstrates the feasibility of achieving at least $50 \%$ energy savings for quick-service restaurants (QSRs) with a simple payback of five years or less. As defined, the 50\% goal involves reducing site energy usage in all eight U.S. climate zones, relative to buildings constructed to just meet minimal code-compliant requirements of ANSI/ASHRAE/IESNA Standard 90.1-2004, Energy Standard for Buildings Except Low-Rise Residential Buildings, before renewable energy is used.

PNNL, with input from many contributors and other sources of information, performed the research, analysis, and documentation summarized in this Technical Support Document (TSD). This project was conducted in collaboration with two industrial partners that specialize in commercial kitchen energy efficiency: the Halton Company and the Pacific Gas and Electric (PG\&E) Food Service Technology Center (FSTC) operated by Fisher-Nickel, Inc. For this analysis, PNNL developed a $2500 \mathrm{ft}^{2}\left(232 \mathrm{~m}^{2}\right)$ QSR building model that was based on actual floor plans in prototypical QSR design drawings. PNNL used EnergyPlus, a state-of-art energy simulation program, to determine the energy savings provided by the EEM package. The prototype building was analyzed in all eight U.S. climate zones that were further divided into moist, dry, and marine regions in which 16 representative climate cities were identified. The TSD establishes the baseline energy use by end-use category in a typical QSR, and provides the site energy and energy cost savings from implementation of the recommended EEMs. Finally, this TSD provides an estimate of the incremental first costs and simple payback years for an energy-efficient QSR in various climate locations.

Table ES.1 summarizes the recommended EEMs for QSRs. Implementation of these EEMs can achieve a weighted-average energy savings of $45 \%$ across the nation, ranging from $41 \%$ to $52 \%$ by climate zone. Cost-effectiveness analysis to implement the EEMs shows a payback period ranging from 1.5 years to 3.5 years, depending on the climate location. These results are summarized for the 16 representative cities in Table ES.2.

The project goal was to enable QSRs to achieve whole-building energy savings of at least $50 \%$ across all eight U.S. climate zones. Although we found that a national-weighted-average energy savings of $45 \%$ can be achieved, only the two coldest climates were able to reach the $50 \%$ energy-saving target. The key reason is that QSR is a special building type in which energy use is driven by very intensive process loads (i.e., the energy used for food preparation and storage). Process loads constitute $45 \%$ to $65 \%$ of wholebuilding energy consumption in a typical QSR. We have achieved significant energy savings in this area with optimized kitchen ventilation system and innovative food preparation/storage technologies (Figure ES.1), but technologies are not yet available (from multiple vendors) to allow us to attain the 50\% energy savings goal in all climate zones. If the process loads are removed from Figure ES.1, the energy savings from the building-related components are well beyond the 50\% energy saving goal, ranging from 55\% in warm climates to $65 \%$ in cold climates. 
Table ES.1. Summary of Recommended EEMs for the QSR

\begin{tabular}{ll}
\hline ENVELOPE & \\
\hline Enhanced building opaque insulation & $\begin{array}{l}\text { Exterior walls: R-13 to R-13 plus R-18.8 continuous insulation in various } \\
\text { climates } \\
\text { Roofs: R-20 to R-35 in various climates } \\
\text { Floors: up to R-20 vertical insulation }\end{array}$ \\
High-performance window glazing & $\begin{array}{l}\text { Double pane windows with low-emissivity film and high visible } \\
\text { transmittance for daylight harvesting } \\
\text { Cool roofs in climate zones 1 through 3 }\end{array}$ \\
Cool roofs & $\begin{array}{l}\text { Efficient lamps and ballasts to reduce lighting power density to 0.83 W/ft } \\
\text { OIGHTING }\end{array}$ \\
\hline Interior Lighting & $\begin{array}{l}\text { Reduced lighting power allowance } \\
\text { Bi-level switching and photocell-controlled exterior lights } \\
\text { Daylight dimming controls in dining area }\end{array}$ \\
Daylerior Lighting & Ultra-efficient cooling appliances \\
\hline KITCHEN APPLIANCES & $\begin{array}{l}\text { ECM motor in walk-in cooler/freezer, additional insulation, waste heat } \\
\text { recovery from refrigerant to preheat hot water etc. }\end{array}$ \\
\hline Commercial kitchen appliances & \\
Refrigeration & Air conditioners with premium cooling efficiency \\
HVAC SYSTEMS & $\begin{array}{l}\text { Reduced exhaust flow rate for ultra-efficient cooking appliances and } \\
\text { efficient exhaust hoods } \\
\text { Demand-controlled exhaust based on cooking appliance schedule }\end{array}$ \\
\hline System efficiency & $\begin{array}{l}\text { Runaround coil heat recovery to preheat outdoor air with waste heat from } \\
\text { kitchen exhaust hood } \\
\text { Broader use of airside economizer across climate zones and extended } \\
\text { cooling capacity to cover 5-ton air units }\end{array}$ \\
Kitchen exhaust hoods & Gas-fired condensing water heater with 95\% thermal efficiency \\
\hline
\end{tabular}

Table ES.2. Results Summary for Recommended EEM Package

\begin{tabular}{clcc|clcc}
\hline $\begin{array}{c}\text { Climate } \\
\text { Zone }\end{array}$ & \multicolumn{1}{c}{ City } & $\begin{array}{c}\text { Energy } \\
\text { Savings, } \\
(\%)\end{array}$ & $\begin{array}{c}\text { Simple } \\
\text { Payback } \\
\text { (Years) }\end{array}$ & $\begin{array}{l}\text { Climate } \\
\text { Zone }\end{array}$ & \multicolumn{1}{c}{ City } & $\begin{array}{c}\text { Energy } \\
\text { Savings, } \\
(\%)\end{array}$ & $\begin{array}{c}\text { Simple } \\
\text { Payback } \\
\text { (Years) }\end{array}$ \\
\hline 1A & Miami & 43 & 1.5 & 4B & Albuquerque & 43 & 1.6 \\
2A & Houston & 44 & 1.5 & 4C & Seattle & 43 & 2.4 \\
2B & Phoenix & 43 & 1.7 & 5A & Chicago & 47 & 3.3 \\
3A & Atlanta & 44 & 1.5 & 5B & Denver & 44 & 1.9 \\
3B & Los Angeles & 41 & 2.5 & $6 \mathrm{~A}$ & Minneapolis & 49 & 3.0 \\
3B & Las Vegas & 43 & 1.6 & 6B & Helena & 46 & 2.9 \\
3C & San Francisco & 43 & 3.5 & 7 & Duluth & 50 & 2.7 \\
4A & Baltimore & 45 & 1.6 & 8 & Fairbanks & 52 & 2.8 \\
\hline
\end{tabular}




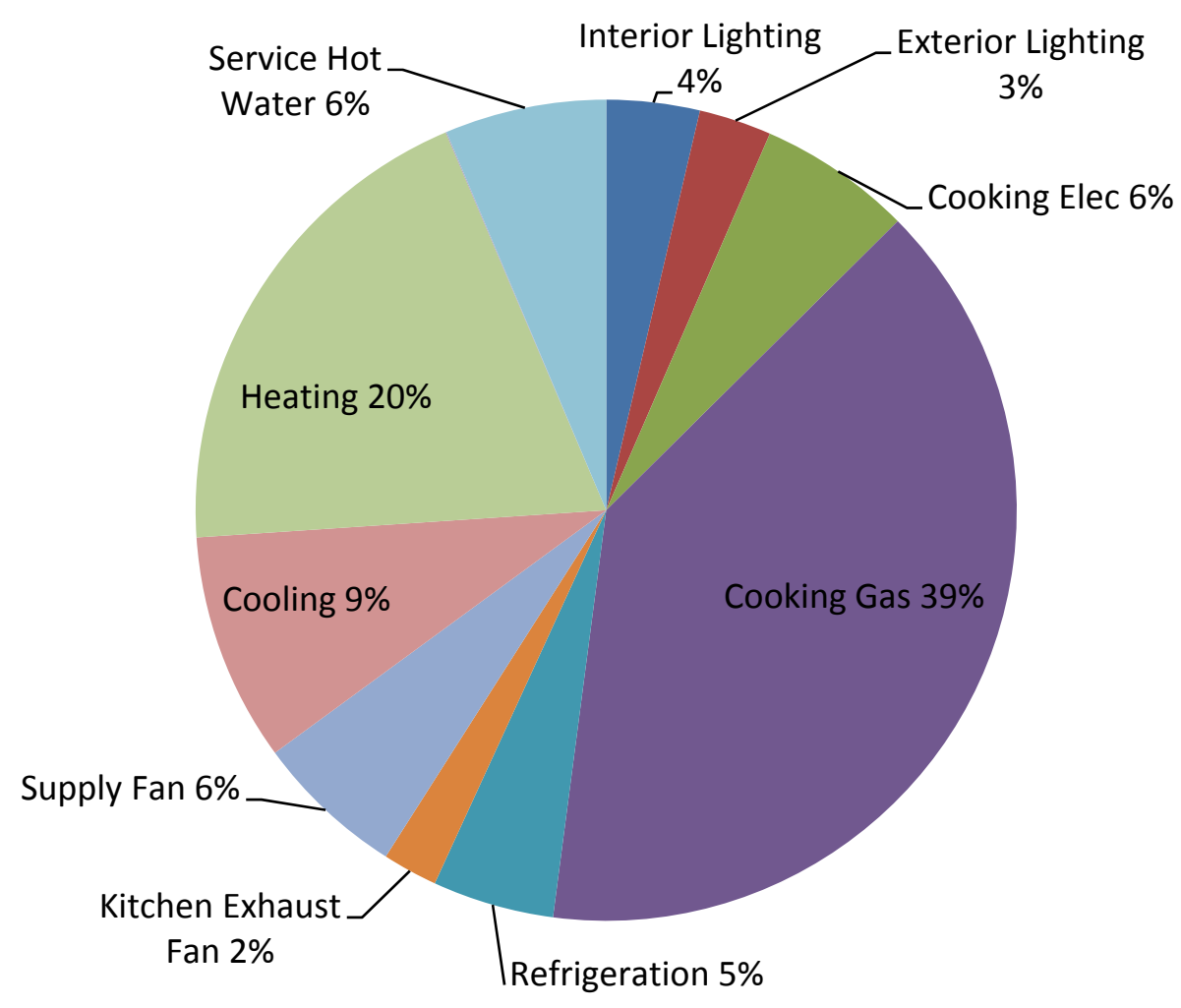

Figure ES.1. Proportion of Energy Savings from Different End-Use Categories

This work is related to other technical support documents sponsored by DOE/BTP. Prior to this report, PNNL has published three TSDs that focused on achieving 50\% energy-savings in small offices, medium offices, and highway lodging, respectively. DOE/BTP also has sponspored the National Renewable Energy Laboratory to develop TSDs for large offices, large hospitals, and general merchandise stores. DOE/BTP plans to use the previously published TSDs to initiate development of the 50\% Advanced Energy Design Guide (AEDG) series, which will be published by ASHRAE and its partner organizations with DOE's support. ${ }^{1}$

This TSD might be used for technical background and as a starting point to support development of a new AEDG for Quick-Service Restaurants, targeting 50\% savings in the future. The QSR TSD also may be used independently to demonstrate the feasibility of achieving $40 \%$ to $50 \%$ whole-building energy savings with very favorable (i.e., short) investments payback periods. In addition, design teams may use this TSD directly to support design of QSRs that feature both exemplary energy performance and quick paybacks on the investment in energy efficiency. Some of the EEMs also are applicable to energyefficient retrofits in restaurants. Design teams that use the information in this report should follow an integrated design process and use additional analysis to evaluate the specific conditions of the individual project.

\footnotetext{
${ }^{1}$ The published 30\% AEDG guides can be downloaded free from http://www.ashrae.org/technology/page/938.
} 



\section{Acknowledgments}

This document was prepared by Pacific Northwest National Laboratory (PNNL) for the DOE's Building Technologies Program. The authors would like to thank Dr. Dru Crawley, former Team Lead of Building Technologies Commercial Buildings Integration Research and Development, for his dedicated support and thoughtful guidance on the early stages of this project and Mr. Jerome Lam for carefully guiding us to project completion.

The authors would like to thank all the external peer reviewers for their tremendous volunteer efforts and insightful reviews of our energy analysis work during the development of this report. Without their expertise in reviewing the energy efficiency measures covering envelope, lighting, kitchen appliances, HVAC systems, and service water heating systems, this document would be considerably less rigorous. Frank Kohout from McDonald's Corporation and Kristin Field from National Renewable Energy Laboratory specifically provided written review comments on an earlier draft of this report. Their insightful review comments and PNNL's responses are documented in Appendix C of this report.

The authors would like to recognize the support of the Pacific Gas and Electric Company (PG\&E) and the company's commitment to the food service industry, through its Food Service Technology Center (FSTC). The FSTC provided the information necessary to assist designers and customers in improving the performance and energy efficiency of kitchen appliances and restaurant HVAC systems.

The authors also would like to recognize Andrew Nicholls, the Program Manager who oversees the Commercial Building Integration and Deployment Program at PNNL, for his strong support of this project. The authors greatly appreciate the assistance of Todd Taylor at PNNL. Todd constructed the cluster simulation structure in EnergyPlus, which allowed us to evaluate the many variations of energy efficiency technologies in a timely fashion to meet the project's compressed schedule. Mark Halverson and Brian Thornton at PNNL provided very detailed reviews on this report. Cary Counts and Mike Parker at PNNL provided the editorial and document production reviews for the report as well.

This project was a true team effort and the authors would like to express their deep appreciation to everyone who contributed to the completion of this work.

Bing Liu, P.E., C.E.M., LEED AP

Project Manager

Pacific Northwest National Laboratory 



\section{Acronyms and Abbreviations}

AEDG

AFO

AFUE

AIA

ANSI

ASHRAE

BSS

BTP

CAV

CBEAs

CBECS

CBPs

CBP

CDD

CEC

CEUS

$\mathrm{CF}$

COP

$\mathrm{CPU}$

DOAS

DOE

DX

ECW

$\mathrm{E}_{\mathrm{C}}$

EEM

EER

EIA

EPDM

EPRI

$\mathrm{E}_{\mathrm{T}}$

EUI

EXF

$\mathrm{F}_{\mathrm{L}}$

$\mathrm{F}_{\mathrm{r}}$

$\mathrm{F}_{\mathrm{s}}$

FSTC

$\mathrm{F}_{\mathrm{u}}$

HDD

HVAC

ICC
Advanced Energy Design Guide

asphalt, fiberglass, other

average fuel utilization efficiency

American Institute of Architects

American National Standards Institute

American Society of Heating, Refrigerating and Air-Conditioning Engineers

brick, stone, stucco

Building Technologies Program

constant air volume

Commercial Building Energy Alliances

Commercial Building Energy Consumption Survey

Commercial Building Partnerships

concrete, block or poured

cooling degree day

California Energy Commission

California Commercial End-Use Survey

compact fluorescent

coefficient of performance

central processing unit

dedicated outdoor air system

U.S. Department of Energy

direct-expansion

Energy Center of Wisconsin

combustion efficiency

energy efficiency measure

energy efficiency ratio

Energy Information Administration

ethylene-propylene-diene-terpolymer membrane

Electric Power Research Institute

thermal efficiency

energy use intensity

exfiltration

latent load factor

sensible radiant factor

sensible convective factor

Food Service Technology Center

usage factor

heating degree day

heating, ventilation, and air conditioning

International Code Council 


\begin{tabular}{|c|c|}
\hline IECC & International Energy Code Council \\
\hline IES & Illuminating Engineering Society \\
\hline INC & incandescent \\
\hline KX & kitchen exhaust \\
\hline LBNL & Lawrence Berkeley National Laboratory \\
\hline LPD & lighting power density \\
\hline MUA & make-up air \\
\hline NC3 & National Commercial Construction Characteristics \\
\hline NREL & National Renewable Energy Laboratory \\
\hline NZEB & net-zero energy building \\
\hline $\mathrm{OA}$ & outdoor air \\
\hline PCCP & pre-cast concrete panels \\
\hline PG\&E & Pacific Gas and Electric \\
\hline PNNL & Pacific Northwest National Laboratory \\
\hline PRS & plastic, rubber, synthetic \\
\hline QSR & quick-service restaurant \\
\hline $\mathrm{R}$ & ratio of supply fan power to total equipment power at the rating condition \\
\hline RA & return air \\
\hline RTU & roof top unit \\
\hline SA & supply air \\
\hline SEER & seasonal energy efficiency ratio \\
\hline SHGC & solar-heat-gain coefficient \\
\hline SL & standby loss \\
\hline SMP & sheet metal panel \\
\hline SSPC & ASHRAE Standing Standard Project Committee \\
\hline SSTS & siding, shingles, tiles, shakes \\
\hline $\mathrm{SWH}$ & service water heating \\
\hline TRA & transfer air \\
\hline TSD & Technical Support Document \\
\hline TX & restroom exhaust \\
\hline UA & standby heat loss coefficient \\
\hline USGBC & U.S. Green Building Council \\
\hline $\mathrm{V}$ & rated storage tank volume \\
\hline VT & visible transmittance \\
\hline w.c. & water column \\
\hline WSSO & wood shingles, shakes, other \\
\hline WWR & window-to-wall ratio \\
\hline
\end{tabular}




\section{Contents}

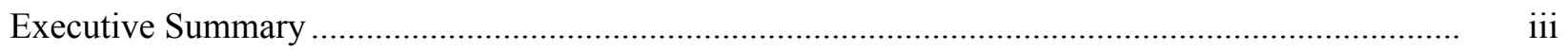

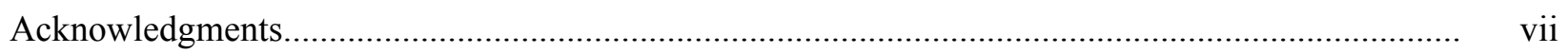

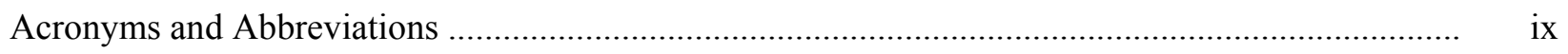

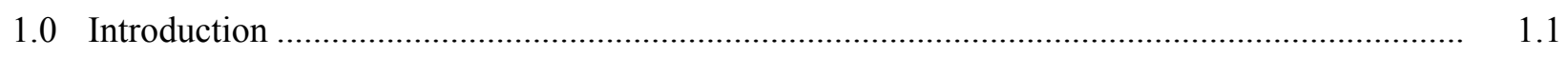

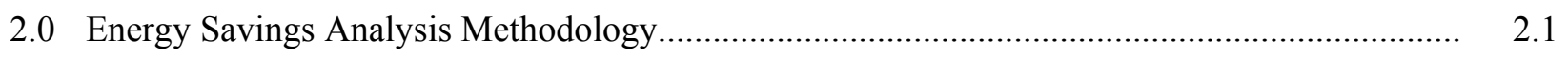

2.1 Energy Savings Evaluation Approach........................................................................ 2.1

2.2 Simulation Tool Description ..................................................................................... 2.2

2.3 Climate Zones and Construction Weighting Factors ................................................... 2.2

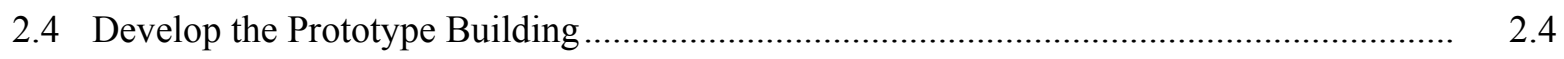

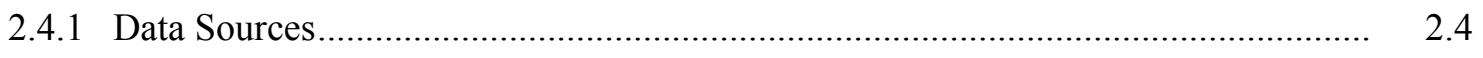

2.4.2 Prototype Building Architectural Features ....................................................... 2.7

2.4.3 Prototype Building Operating Hours............................................................ 2.11

3.0 Quick-Service Restaurant Baseline Models .................................................................... 3.1

3.1 Baseline Building Envelope Characteristics ............................................................... 3.1

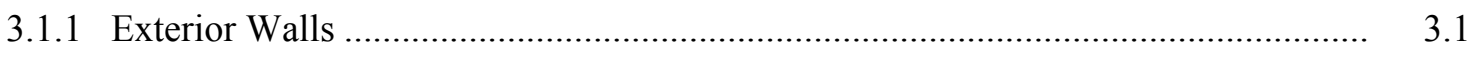

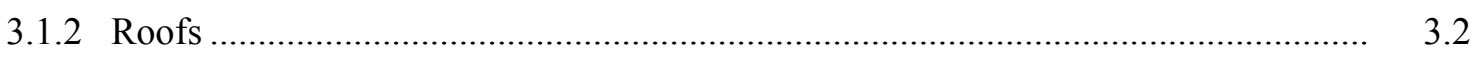

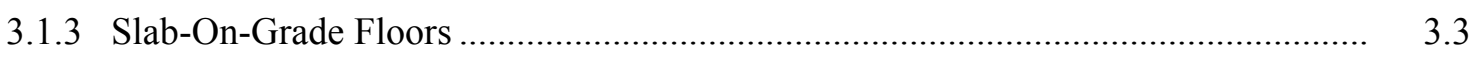

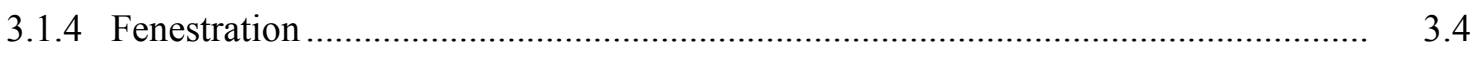

3.1.5 Air Infiltration through Building Envelope Leakage .......................................... 3.5

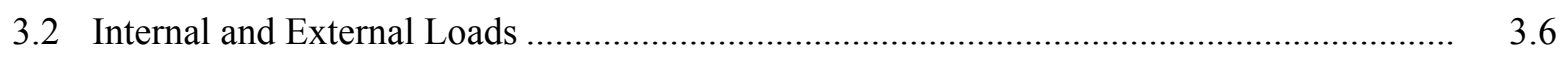

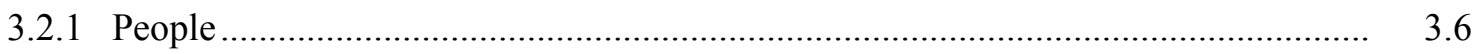

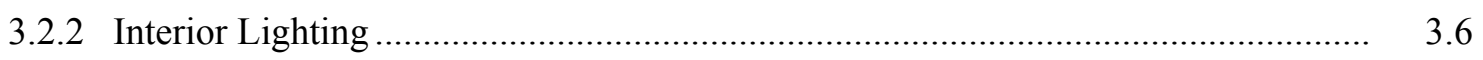

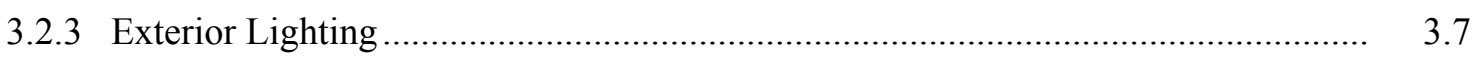

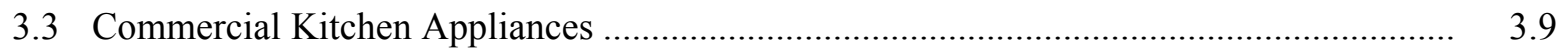

3.3.1 Estimating Cooking Energy Use .................................................................. 3.9

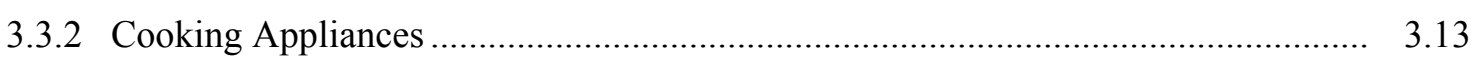

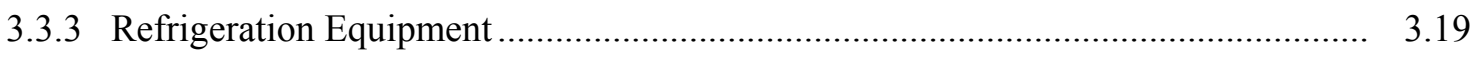

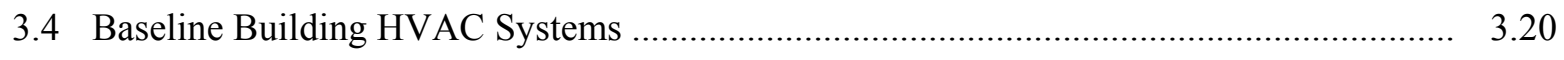

3.4.1 Kitchen Ventilation System ..................................................................... 3.22

3.4.2 Building HVAC Operating Schedules ........................................................... 3.23

3.4.3 Heating and Cooling Thermostat Set Point ....................................................... 3.24

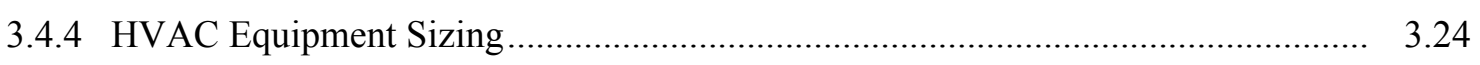

3.4.5 HVAC Equipment Efficiency ….................................................................... 3.24

3.4.6 HVAC System Fan Power........................................................................... 3.25

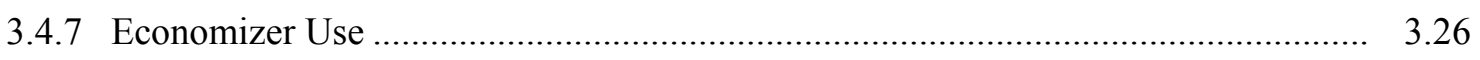

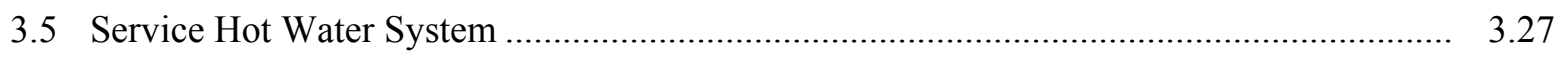


3.5.1 Hot Water Usage and Storage Tank Size ......................................................... 3.27

3.5.2 Heater Input Capacity, Thermal Efficiency, and Standby Heat Loss...................... 3.28

4.0 Advanced Low-Energy Use Building Models.......................................................................

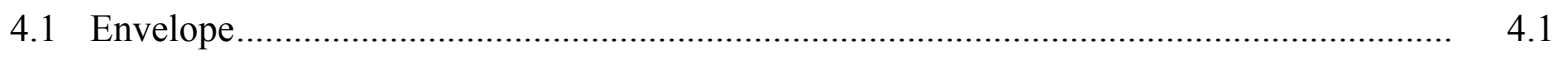

4.1.1 Enhanced Insulation for Opaque Assemblies................................................... 4.1

4.1.2 High-Performance Windows ............................................................................ 4.3

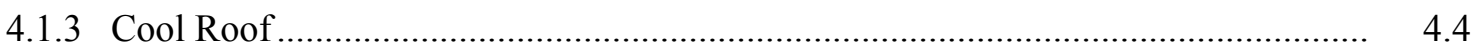

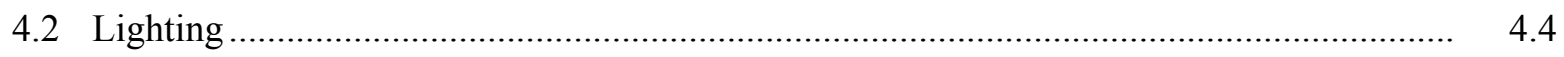

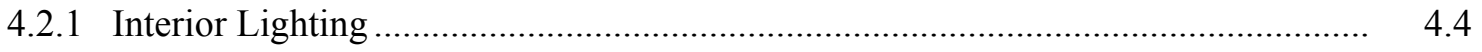

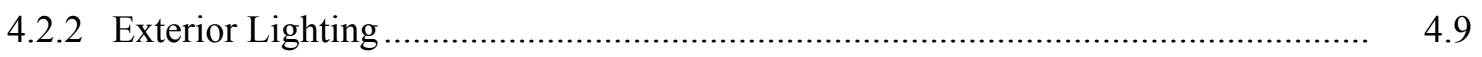

4.3 Commercial Kitchen Appliances ...................................................................... 4.11

4.3.1 Estimating Cooking Energy Use ...................................................................... 4.11

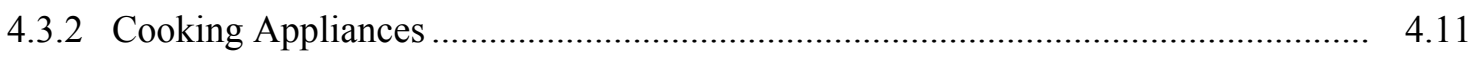

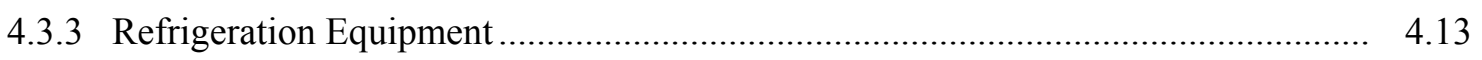

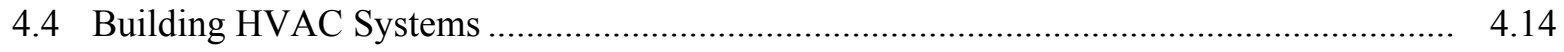

4.4.1 Kitchen Exhaust Hood ............................................................................... 4.14

4.4.2 HVAC System Configuration ......................................................................... 4.15

4.4.3 Heat Recovery from Exhaust Flow with a Runaround Loop .................................. 4.16

4.4.4 HVAC System Efficiency ........................................................................... 4.17

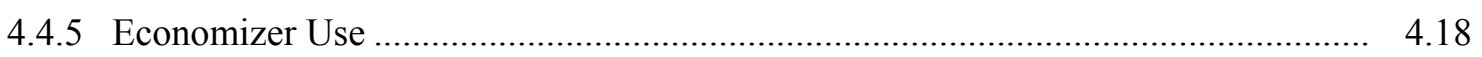

4.5 Service Hot Water System …….............................................................................. 4.19

4.5.1 High Efficient Water Heater........................................................................... 4.19

4.5.2 Preheating Service Hot Water with Refrigerant Heat Recovery ............................ 4.19

5.0 Energy and Energy Cost Savings Results....................................................................... 5.1

5.1 Summary of Recommended Energy Efficiency Measures............................................... 5.1

5.2 Energy Savings Results .......................................................................................... 5.2

5.3 Energy Cost Savings Results................................................................................. 5.12

5.4 Energy and Energy Cost Savings Results of EEM Packages ......................................... 5.12

6.0 Cost-Effectiveness Analysis .................................................................................. 6.1

6.1 Basis for Incremental Energy Efficiency Measure Costs................................................... 6.1

6.2 Cost Analysis - Complete EEM Package ................................................................... 6.2

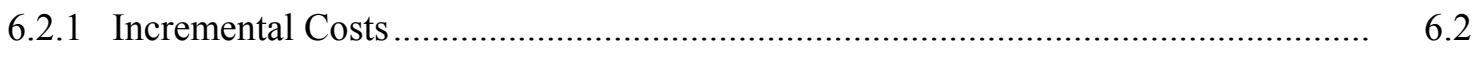

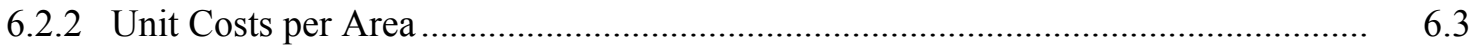

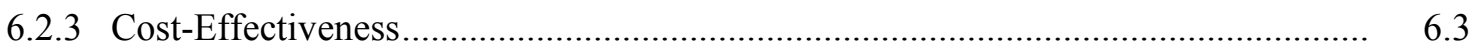

6.3 Cost Analysis - Individual EEM Packages ............................................................... 6.6

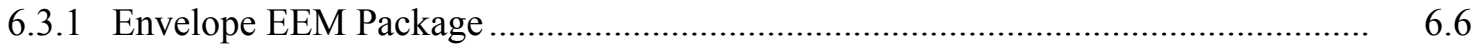

6.3.2 Lighting EEM Package .............................................................................. 6.8

6.3.3 Commercial Kitchen Appliance EEM Package …............................................... 6.9

6.3.4 Mechanical Systems EEM Package …............................................................... 6.9 
6.4 A Perspective on Costs for Advanced Buildings ....................................................... 6.14

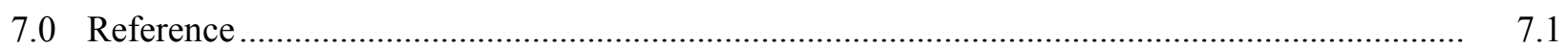

Appendix A - Energy Performance of QSRs with Alternative Baseline HVAC Configurations

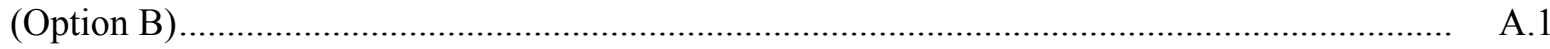

Appendix B - Energy Modeling Inputs …............................................................................ B.1

Appendix C - Review Comments and Responses on the Draft TSD Report ................................. C.1 


\section{Figures}

ES.1 Proportion of Energy Savings from Different End-Use Categories ...................................... v

2.1 DOE-Developed Climate Zone Map ................................................................................ 2.3

2.2 Building Shape Distribution of Post-1980 QSR Buildings ................................................. 2.7

2.3 Example of a QSR Building Floor Plan from the Dodge Drawings ...................................... 2.8

2.4 Thermal Zones of the QSR Prototype Building .................................................................. 2.9

2.5 Window-to-Wall Area Fraction of Post-1980 QSR Buildings............................................... 2.11

2.6 Axonometric View of the Prototype QSR Building.......................................................... 2.11

2.7 Building Weekly Operating Hours of Post-1980 QSR Buildings ........................................... 2.12

2.8 Prototype QSR Occupancy Schedules ........................................................................... 2.12

3.1 Typical Lighting Schedule for Baseline ............................................................................ 3.7

3.2 Annual Cooking EUI Distribution of Post-1980 QSRs........................................................ 3.9

3.3 Relationship Between Building Floor Area and Annual Cooking Energy EUI for Post-1980

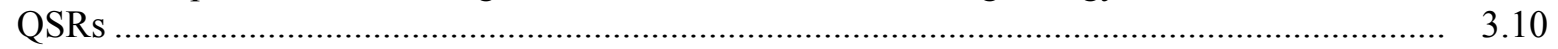

3.4 Total Building EUI Variation with Square Footage for QSRs.............................................. 3.12

3.5 Baseline Fractional Usage Profile for the Hooded Cooking Griddle ...................................... 3.18

3.6 Baseline Fractional Usage Profile for the Hooded Cooking Fryer .......................................... 3.18

3.7 Baseline Fractional Usage Profile for the Unhooded Cooking Equipment that Operates

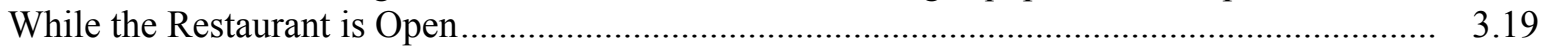

3.8 Baseline Fractional Usage Profile for the Unhooded Cooking Equipment only Used During Breakfast Hours ................................................................................................................ 3.19

3.9 HVAC system configuration for Option A ................................................................. 3.21

3.10 HVAC system configuration for Option B .................................................................. 3.22

3.11 Baseline HVAC System Operating Schedule ................................................................... 3.23

3.12 Hot Water Load Profile for Baseline QSR Model .................................................................. 3.28

4.1 Change of Interior Lighting Schedules from Occupancy Sensors .......................................... 4.6

4.2 The Dining Zone with View Windows in the Baseline Model ............................................. 4.8

4.3 The Dining Zone with Separate Daylighting and View Windows in the Advanced Model ....... 4.8

4.4 Fractional Schedule for the Kitchen Hood Exhaust Rate.......................................................... 4.15

4.5 Efficient HVAC System Configuration …........................................................................ 4.16

5.1 Percentage Energy Savings by Climate Zone ................................................................. 5.4

5.2 Energy Savings Results by Energy End-Use Categories .................................................. 5.6

5.3 Proportion of Energy Savings from Different End-Use Categories ...................................... 5.10

5.4 Energy Savings Results by Energy End-Use Categories Excluding Refrigeration and

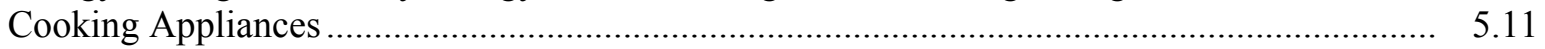

A.1 Comparison of Selected HVAC-Related EUIs, Houston ..................................................... A.1

A.2 Comparison of Selected HVAC-Related EUIs, Atlanta ....................................................... A.2

A.3 Comparison of Selected HVAC-Related EUIs, Los Angles ..................................................... A.2 
A.4 Comparison of Selected HVAC-Related EUIs, Baltimore ..

A.5 Comparison of Selected HVAC-Related EUIs, Chicago

A. 3

A.6 Comparison of Selected HVAC-Related EUIs, Denver..

A. 4 


\section{Tables}

ES.1 Summary of Recommended EEMs for the QSR ................................................................. iv

ES.2 Results Summary for Recommended EEM Package ............................................................ iv

$2.1 \quad$ Representative Climate Cities ................................................................................ 2.4

2.2 Construction Area Weights for All ASHRAE Building Prototypes and Climate Zones ........... 2.6

2.3 Construction Area Weights for Quick-Service Restaurants ................................................... 2.6

2.4 Relationship of CBECS Roof Descriptions and Standard 90.1-2004 Roof Construction.......... 2.10

2.5 Relationship of CBECS Wall Descriptions and Standard 90.1-2004 Wall Construction .......... 2.10

3.1 Baseline Thermal Requirements for Exterior Above-Grade, Wood-Framed Walls ................. 3.2

3.2 Baseline Thermal Requirements for Roofs with Insulation Entirely Above Deck .................. 3.3

3.3 Baseline Thermal Requirements for a Slab-on-Grade Unheated Floor...................................... 3.4

3.4 Baseline Thermal Requirements for Fenestration ............................................................... 3.5

3.5 Baseline Lighting Power Density................................................................................ 3.7

3.6 Baseline Exterior Lighting Power Calculation.................................................................. 3.8

3.7 Historical Food Preparation Energy End Use from Different Sources ................................... 3.11

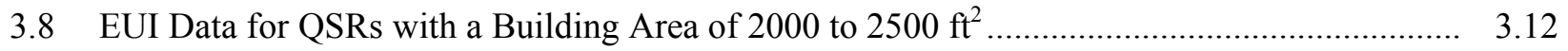

3.9 Variation in Total Building EUI with Building Square Footage for QSRs............................. 3.12

3.10 Major Cooking Equipment Found in Foodservice Establishments Center ............................. 3.13

3.11 Summary of QSR Equipment from the Dodge Database ...................................................... 3.14

3.12 Baseline Griddle Performance Data ............................................................................. 3.15

3.13 Baseline Fryer Performance Data ................................................................................ 3.15

3.14 Baseline Model Appliance Usage Matrix with Percent Occupancy ...................................... 3.15

3.15 Baseline Hooded Equipment ....................................................................................... 3.16

3.16 Baseline Model Equipment Operating During Open Restaurant Hours ................................ 3.17

3.17 Baseline Equipment Operating During Breakfast Hours .................................................... 3.17

3.18 Summary of Reviewed QSR Walk-In Cooler/Freezer from the Dodge Database .................... 3.20

3.19 Baseline Refrigeration Equipment Operating 24 Hours per Day ......................................... 3.20

3.20 Baseline Walk-In Refrigeration Systems ..................................................................... 3.20

3.21 Baseline Kitchen Exhaust Hood Specifications ................................................................ 3.22

3.22 Air Balance for HVAC System - Option A.................................................................... 3.23

3.23 Single Packaged Air Conditioner Baseline Efficiency...................................................... 3.25

3.24 Baseline Exhaust Fan Energy Calculation ....................................................................... 3.26

3.25 Economizer Requirements in Standard 90.1-2004 ............................................................ 3.26

3.26 QSR Service Hot Water Design Capacity Summary .......................................................... 3.28

4.1 Required Thermal Performance for Exterior-Above-Grade, Wood-Framed Walls ................. 4.2

4.2 Required Thermal Performance for Roofs with Insulation Entirely Above Deck .................... 4.2

4.3 Required Thermal Performance for a Slab-On-Grade Unheated Floor..................................... 4.3 
4.4 Required Performance for Fenestration U-factor, SHGC, and VT Values ............................. 4.3

4.5 Interior Lighting Power Reduction .................................................................................

4.6 Lighting Energy Savings from Use of Occupancy Sensors …...............................................

4.7 Exterior Lighting Power Reduction .................................................................................. 4.10

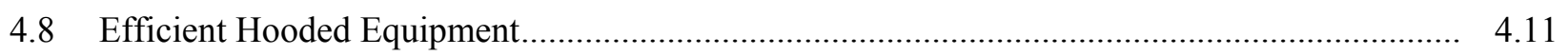

4.9 Efficient Griddle Performance and Production Capacity Information ..................................... 4.11

4.10 Efficient Fryer Performance and Production Capacity Information ........................................ 4.12

4.11 Efficient Hooded Appliance Usage Factors ..................................................................... 4.12

4.12 Unhooded Equipment on During Open Restaurant Hours in Advanced Model ....................... 4.13

4.13 Advanced Equipment Operating During Breakfast Hours.................................................... 4.13

4.14 Efficient Refrigeration Equipment Operating 24 Hours per Day.......................................... 4.14

4.15 Energy-Efficient Walk-In Refrigeration Systems ................................................................. 4.14

4.16 Advanced Exhaust Hood Specifications ...................................................................... 4.15

4.17 Air Balance for Efficient HVAC Configuration .............................................................. 4.16

4.18 Application of Air-to-air Heat Recovery ....................................................................... 4.17

4.19 Higher Efficiency for Packaged Unitary Air Conditioners for the Advanced Case.................. 4.18

4.20 Economizer Requirements in Addendum CY to Standard 90.1-2007 .................................... 4..18

5.1 Energy Use Intensity Weighted by Construction Area ........................................................ 5.5

5.2 Energy Savings Results by Energy End-Use Categories ................................................. 5.7

5.3 Electricity Savings Results by End-Use Category ........................................................ 5.8

5.4 Natural Gas Savings Results by End-Use Category............................................................. 5.9

5.5 Annual Energy Cost Reduction................................................................................... 5.12

5.6 Energy Savings Results for the Building Envelope EEM Package........................................ 5.13

5.7 Energy Cost Savings Results for the Building Envelope EEM Package ................................ 5.14

5.8 Energy Savings Results for the Lighting and Daylighting EEM Package .............................. 5.15

5.9 Energy Cost Savings Results for the Lighting and Daylighting EEM Package........................ 5.16

5.10 Energy Savings Results for the Commercial Kitchen Appliance EEM Package ..................... 5.17

5.11 Energy Cost Savings Results for the Commercial Kitchen Appliance EEM Package............... 5.18

5.12 Energy Savings Results for the Mechanical System EEM Package ...................................... 5.19

5.13 Energy Cost Savings Results for the Mechanical System EEM Package ................................ 5.20

6.1 Cost Calculation Method Summary ….......................................................................... 6.2

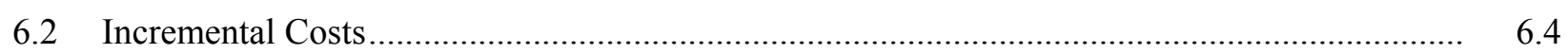

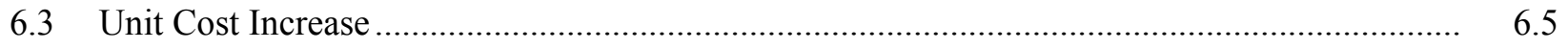

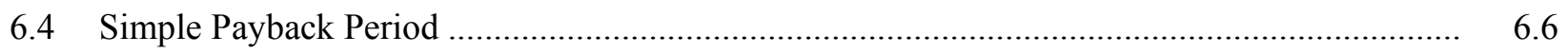

6.5 Incremental Costs for the Envelope EEM Package............................................................. 6.7

6.6 Simple Payback Period for the Envelope EEM Package ..................................................... 6.8

6.7 Incremental Costs for the Kitchen Appliance EEM Package - Minimum Incremental Cost ..... 6.10

6.8 Incremental Costs for the Kitchen Appliance EEM Package - Maximum Incremental Cost.... 6.10

6.9 Simple Payback Period for Kitchen Appliance EEM Package - Minimum Incremental Cost... 6.11 
6.10 Simple Payback Period for Kitchen Appliance EEM Package - Maximum Incremental Cost

6.11

6.11 Incremental Costs for the HVAC EEM Package - Minimum Incremental Cost

6.12 Incremental Costs for the HVAC EEM Package - Maximum Incremental Cost 6.12

6.13 Simple Payback Period for HVAC EEM Package - Minimum Incremental Cost.

6.14 Simple Payback Period for HVAC EEM Package - Maximum Incremental Cost . 6.13

B.1 Baseline and Advanced Model Inputs for QSR IP Units B.1

B.2 Baseline and Advanced Model Inputs for QSR SI Units B.6

B.3 Major Schedules for the Baseline Model B. 11

B.4 Major Schedules for the Advanced Model.

B.5 Performance Curves for the DX Coils Used in the Packaged CAV System B.13 


\subsection{Introduction}

Buildings account for over $40 \%$ of total energy use and over $70 \%$ of electricity use in the United States (DOE 2009). To reduce building energy usage, the U.S. Department of Energy (DOE) has, through its Building Technologies Program (BTP), established a strategic goal to significantly improve the energy efficiency of new and existing commercial buildings across the nation at both speed and scale.

DOE/BTP has implemented a strategy to develop information packages and tools to support realization of $30 \%$ and 50\%, more efficient buildings, relative to ANSI/ASHRAE/IESNA Standard 90.12004: Energy Standard for Buildings Except Low-Rise Residential Buildings (ANSI/ASHRAE/IESNA 2004) . Beginning in FY 2004, DOE has provided financial and technical support for the development of the Advanced Energy Design Guides (AEDG) and Technical Support Documents (TSD) in conjunction with its partnering organizations: the American Society of Heating, Refrigerating and Air-Conditioning Engineers (ASHRAE), the American Institute of Architects (AIA), the Illuminating Engineering Society (IES), and the U.S. Green Building Council (USGBC). ${ }^{1}$

There are two distinct but related products under this element. A TSD is a background report that documents the assumptions and methodologies used to evaluate particular levels of achieved energy performance. An AEDG is a publication targeted at architects and other practitioners that provides specific guidance on how to achieve certain levels of high energy performance in buildings.

With significant financial and technical support from DOE, ASHRAE and its partners have, to date, published six AEDGs focused on new construction in small commercial buildings. The building types covered include small office, small retail, K-12 school, small warehouse and self-storage, highway lodging, and small hospitals and healthcare facilities. ${ }^{2}$ The purpose of these AEDGs is to provide recommendations for achieving at least 30\% energy savings over the minimum code requirements documented in ANSI/ASHRAE/IESNA Standard 90.1-1999 (ANSI/ASHRAE/IESNA 1999).

Having proven the feasibility of $30 \%$ energy savings across a variety of building types, DOE now focuses entirely on informational products to realize $50 \%$ whole-building energy savings levels for a variety of climate zones, building types, energy intensities, and sizes.

The purpose of this TSD is to investigate the feasibility of developing an energy efficiency measure (EEM) package that would enable 50\% whole-building energy savings relative to ANSI/ASHRAE/IESNA Standard 90.1-2004 for quick-service restaurant (QSR) buildings. Prior to development of this TSD, the initial 30\% series guides were developed by a project committee administered under ASHRAE's Special Project procedures. The AEDG project committee included membership from each of the partner organizations. Two of DOE's national laboratories, Pacific Northwest National Laboratory (PNNL) and National Renewable Energy Laboratory (NREL), have provided leadership and energy analysis support to the various AEDG project committees in the past. Proceeding to the 50\% savings level, DOE decided to develop the TSDs first to significantly expedite the speed at which the final guides are provided by ASHRAE to the market to impact actual design decisions in new commercial buildings.

\footnotetext{
${ }^{1}$ In addition, the New Buildings Institute participated in the development of the AEDG for Small Office Buildings.

${ }^{2}$ The published AEDG guides are available for free download at http://www.ashrae.org/technology/page/938.
} 
During FY 2009, PNNL initiated efforts for 50\% energy savings with the medium office and highway lodging TSDs and published two reports in September 2009 (Jiang et al. 2009; Thornton et al. 2009). In FY 2010, PNNL has focused on developing 50\% energy savings paths for quick-service restaurants (this TSD) and small offices (Thornton et al. 2010). In consultation with DOE, PNNL selected these building types for two reasons. First, DOE has launched the Commercial Building Energy Alliances (CBEAs) and the Commercial Building Partnerships (CBPs) that include both QSRs and small office buildings. The goal of the CBEAs and CBPs is ultimately 50\% energy savings for new construction and $30 \%$ energy savings for retrofit. The TSDs will directly support this effort to realize energy efficiency at scale through CBPs portfolio replication for new constructions. In addition, the energy-efficient measures developed in this report may inform the decisions of the energy-efficiency retrofit projects of CBPs and CBEAs. AEDGs and accompanying TSDs also influence retrofit practice, according to the market impact evaluation prepared by the Energy Center of Wisconsin (ECW 2010). Second, with regard to the office subsector, PNNL possesses technical expertise in the area of office buildings, as evidenced by development of the 30\% AEDG for Small Offices and the 50\% Design Technology Packages for Medium Offices.

Publication and use of the two new TSDs for small office buildings and QSRs will lead to additional energy efficiency design improvements that exceed those called for in ASHRAE Standard 90.1-2004,. For reference, office and food services buildings are ranked as the first and sixth largest primary energy consumers in the commercial building sector, respectively. According to Table 3.2.2 of the 2009 Buildings Energy Data Book (DOE 2009), when combined, the office and food service sectors account for $25 \%$ of the primary energy consumption in existing commercial buildings and represent $19 \%$ of the total square footage in the commercial building stock. The recommended package of EEMs will provide a sensible, hands-on approach to design through the use of "off-the-shelf" technologies and products that are practical and commercially-available from major manufacturers. 


\subsection{Energy Savings Analysis Methodology}

For the past decade, industry and academia have accepted whole building energy simulation as a valid design and research tool for modeling and predicting building energy usage. This chapter describes the analysis approach, simulation program, and methodology to evaluate the energy saving impacts of various energy-efficiency measures across all eight U.S. climate zones. To evaluate the energy saving impacts at the national level, PNNL further developed the construction weighting factors and assigned to each climate cities.

The energy savings for this work is based on site energy usage at a typical quick-service restaurant building. Source energy and emissions at the power plant are not provided because such information is specific to the local utility and the mix of fuels and generation technologies used. These factors are outside the scope of this project. For readers who are interested, information for determining source energy and emissions is available in the publication Source Energy and Emission Factors for Energy Use in Buildings (Deru and Torcellini 2007).

\subsection{Energy Savings Evaluation Approach}

This project adopts an energy saving evaluation approach that is similar to the one used for the development of the recently completed 50\% TSDs for highway lodging, medium office, and small office building (Jiang et al. 2009; Thornton et al. 2009; Thornton et al. 2010), and to the technical analysis performed for the earlier 30\% AEDG series. The 30\% AEDG series used 15 climate locations to represent the eight climate zones defined in the Standard 90.1-2004 (Jarnagin et al. 2006; Liu et al. 2006; Liu et al. 2007; Pless et al. 2007; Jiang et al. 2008; Bonnema et al. 2010). In this report, 16 representative cities were selected (Table 2.1 in Section 2.3). Section 2.3 describes the reason to select slightly different climate cities for this work. The $2500 \mathrm{ft}^{2}\left(232 \mathrm{~m}^{2}\right)$ QSR building described in DOE Commercial Reference Buildings was used as the starting point of the prototype QSR model development in this project (DOE 2010a). During the course of this project, modifications were made to the reference building model and they are described in Section 2.4.

The energy savings are evaluated based on the difference between the onsite energy usage of the minimally-code-compliant (baseline) QSRs and the advanced low-energy buildings with various EEMs evaluated in this project. For the baseline buildings, for those components, system configurations, and operations that are not regulated by Standard 90.1-2004, PNNL based the model inputs on common design practices, metering data, and professional judgments. The purpose of the building energy simulation analysis is to assess and quantify the energy savings potential of the TSD's final recommendations. The following steps are taken to reach this goal:

- Develop a prototypical QSR building description. Section 2.4 describes the development of the prototypical building.

- Create baseline models from the prototype building to meet the requirements of ASHRAE Standard 90.1-2004 in all 16 climate cities. Chapter 3.0 documents the model inputs and assumptions for the baseline models.

- Identify and select EEMs to evaluate. The goal is to develop an integrated package of EEMs that can reach the $50 \%$ energy savings target while also providing a five-year or less payback. The integrated 
package should reduce loads by modifying the envelope and lowering lighting and plug load usage, and then meeting those reduced loads with more efficient HVAC strategies. The EEMs PNNL selected always had to be available in the market from at least two vendors and to meet the simple payback test. The starting point for identifying potential technologies include the work of the ASHRAE Standing Standard Project Committee (SSPC) 90.1, which is engaged in developing the next generation of Standard 90.1, and the previously published TSDs and ADEGs. Chapter 4.0 documents the model inputs and assumptions for the advanced models when incorporating these measures.

- Evaluate site energy impacts and energy cost savings of the EEMs. Chapter 5.0 summarizes the site energy and energy cost saving results for all locations and the final EEM recommendations by climate zone.

- Develop incremental first costs of the EEMs. The cost effectiveness of the recommended EEMs is presented in Chapter 6.0.

\subsection{Simulation Tool Description}

EnergyPlus version 5.0 (released in April 2010) was used to assess the energy savings potential of the EEMs in this project. EnergyPlus, which has been under continuous development by DOE since 1996 (DOE 2010b), is a complex building energy simulation program for modeling building heating, cooling, lighting, ventilation, and other energy flows in buildings. While it is based on the most popular features and capabilities of BLAST and DOE-2, EnergyPlus includes many innovative simulation capabilities, such as time steps of less than 1 hour, modular systems and plants integrated with heat balance-based zone simulation, multizone air flow, thermal comfort, and renewable energy systems. EnergyPlus is an extensively tested program with formal validation efforts repeated for every release. ${ }^{1}$

All energy simulations are completed within a PNNL Linux simulation infrastructure, which manages massive input and output of the EnergyPlus simulations. This infrastructure includes creating EnergyPlus input files by a PNNL-developed program known as GPARM, submitting input files to a computing cluster with over 80 central processing units (CPUs) for batch simulation, and extracting energy end-use results automatically.

\subsection{Climate Zones and Construction Weighting Factors}

The 30\% AEDG series published to date used standardized climate zones that have been adopted by International Energy Code Council (IECC) and ASHRAE for both residential and commercial applications. This results in a common set of eight climate zones covering the United States for use in codes and standards (see Figure 2.1) (Briggs et al. 2003). The climate zones are designated Zones 1 to 8, with heating degree days (HDDs) increasing and cooling degree days (CDDs) decreasing as the zone number increases. The climate zones are further divided into moist, dry, and marine regions. Based on the same criteria, these climate zones may be mapped to other climate locations for international use as well.

\footnotetext{
${ }^{1}$ For the details of the test and validations of EnergyPlus program, go to http://apps1.eere.energy.gov/buildings/EnergyPlus/testing.cfm. Last accessed on July 8, 2010.
} 


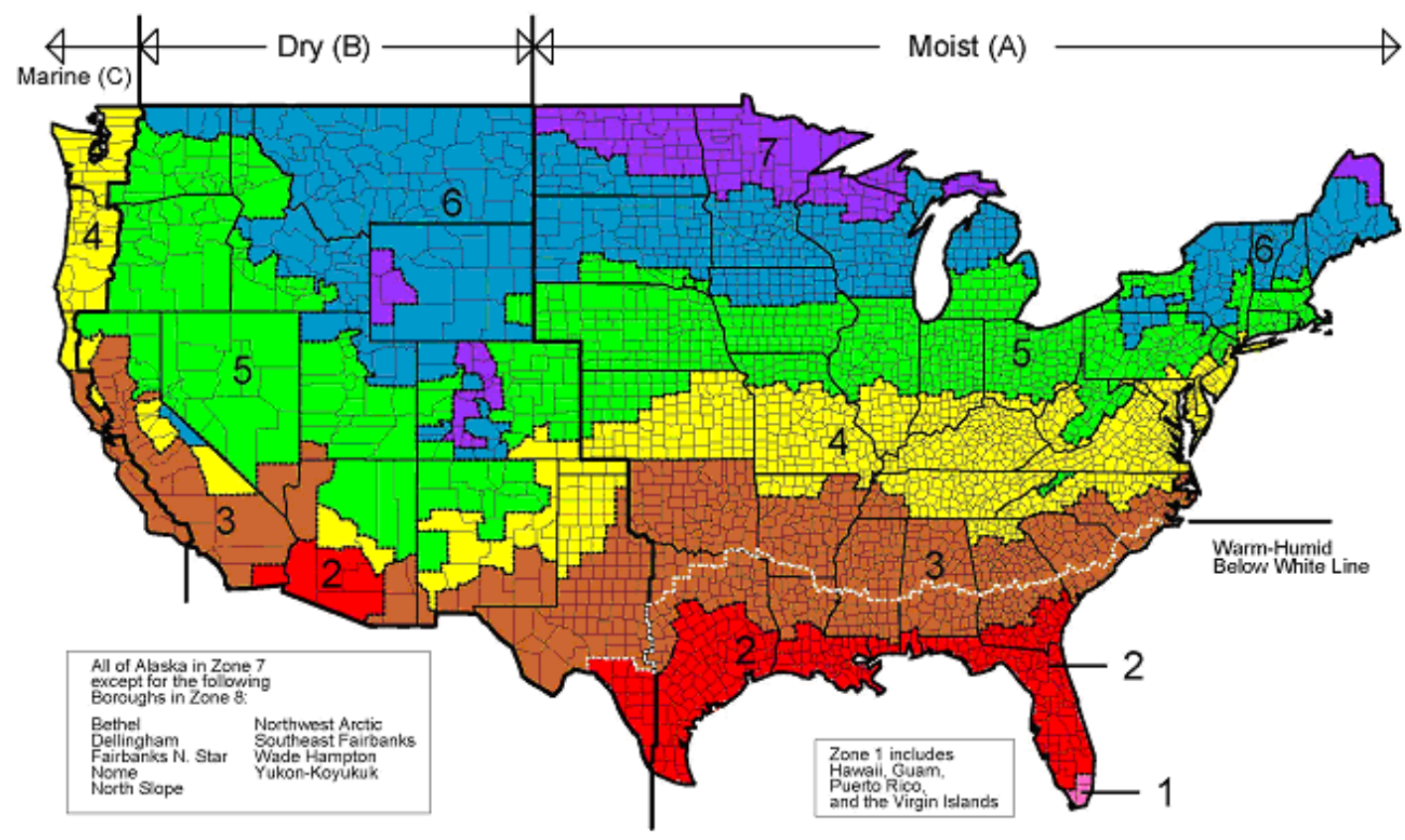

Figure 2.1. DOE-Developed Climate Zone Map

For this report, a specific climate location (city) is selected as a representative for each climate zone. The 30\% AEDG series selected 15 cities as the representative climate locations. As shown in Table 2.1, a revised set of 16 cities was used in this study. Use of 16 cities balances the representation of the climate zones and the number of buildings in the climate zones. Two locations, Los Angeles, California, and Las Vegas, Nevada, were selected for climate zone 3B because they are two important locations with very different climates, which is evident from the results of the energy simulations of the DOE's Commercial Reference Building Models (DOE 2010a). We have designated the two 3B climate zones as "3B-CA" for the California coast in climate zone $3 \mathrm{~B}$ and "3B-other".

The representative climate locations are assigned weighting factors that are based on the new construction floor areas from 2003 to 2007, as presented in a PNNL study using the McGraw-Hill Construction Projects Starts Database (Jarnagin and Bandyopadhyay 2010). This study presents weighting factors for all 16 ASHRAE prototype buildings that PNNL developed to support the development of ASHRAE Standard 90.1-2010, as shown in Table 2.2, with QSRs shown in bold. Table 2.3 shows just the QSR weighting factors normalized to total $100 \%$ and labeled according to the representative cities shown above. The weights for QSRs by climate locations were used to calculate weighted average energy savings results for the whole country. These results are presented in Chapter 5.0. 
Table 2.1. Representative Climate Cities

\begin{tabular}{lll}
\hline Climate Zone & Representative City & Climate Characteristics \\
\hline 1A & Miami, Florida & very hot, humid \\
2A & Houston, Texas & hot, humid \\
2B & Phoenix, Arizona & hot, dry \\
3A & Atlanta, Georgia & warm, humid \\
3B-CA & Los Angeles, California & warm, coastal \\
3B-other & Las Vegas, Nevada & warm, dry \\
3C & San Francisco, California & marine \\
4A & Baltimore, Maryland & mixed, humid \\
4B & Albuquerque, New Mexico & mixed, dry \\
4C & Seattle, Washington & mixed, marine \\
5A & Chicago, Illinois & cool, humid \\
5B & Denver, Colorado & cool, dry \\
6A & Minneapolis, Minnesota & cold, humid \\
6B & Helena, Montana & cold, dry \\
7 & Duluth, Minnesota & very cold \\
8 & Fairbanks, Alaska & subarctic \\
\hline
\end{tabular}

\subsection{Develop the Prototype Building}

The first step of the energy savings analysis is to develop a QSR prototype building and determine its basic building characteristics, such as size, form, envelope type, operation schedule, etc. The prototype building model should represent the typical design of QSR buildings so that the energy analysis on such a building would be a reasonable reference when evaluating the energy saving potential. The characteristics defined in this section remain unchanged in both the baseline and advanced models.

\subsubsection{Data Sources}

The QSR prototype building was not developed from scratch. The following information sources were used for the prototype development:

- The $2500 \mathrm{ft}^{2}\left(232 \mathrm{~m}^{2}\right.$ ) QSR building model (referred as the DOE Reference Building in this report) from the DOE's Commercial Reference Building series (DOE 2010a)

- The 2003 Commercial Building Energy Consumption Survey (CBECS 2003)

- The National Commercial Construction Characteristics (NC3) Database (Richman et al. 2008) ${ }^{1}$

- The McGraw Hill/F.W. Dodge building plans from the F.W. Dodge database ${ }^{2}$

- Input from industry experts.

The DOE Reference Building was the starting point for QSR prototype development in this project. DOE's Building Technologies Program, in conjunction with three of its national laboratories including PNNL, NREL, and Lawrence Berkeley National Laboratory (LBNL), developed the Commercial Reference Buildings, formerly known as commercial building benchmark models. These reference

\footnotetext{
${ }^{1} \mathrm{NC} 3$ is an internal database developed by PNNL with DOE/BTP support to represent nationwide commercial construction energy-related characteristics. The database was derived from F.W. Dodge drawings.

${ }^{2}$ The F.W. Dodge database is available at http://dodge.construction.com/analytics/MarketMeasurement/BuildingStockDatabase.asp.
} 
buildings provide complete descriptions for whole building energy analysis using EnergyPlus simulation software. There are 16 building types in DOE Reference Buildings that represent approximately $70 \%$ of the commercial buildings in the U.S. In this project, some basic building characteristics in the DOE's Reference QSR Buildings were directly used in the prototype QSR.

The CBECS (2003) data sets are publicly available and provide statistical results from periodic national surveys of existing commercial buildings and their energy suppliers performed by the Energy Information Administration (EIA). While the energy savings analysis in this TSD is intended for new construction, PNNL assumes that basic building characteristics in new construction would be similar to recent construction covered by the CBECS. The statistical results in the CBECS also provide very useful information about the common features of QSR buildings. In the 2003 CBECS, a total of 54 buildings were reported with food service as their principal building activity and with fast food as their specific building activity. Among these building, 38 buildings constructed after 1980 are selected as the references for the current project.

NC3 is an internal PNNL database of nationwide commercial construction energy-related characteristics based on building information from the McGraw Hill/F.W. Dodge commercial building plans submitted for construction bids (Richman et al. 2008). The building plans were developed between 1996 and 2007. The NC3 database includes 11 QSR buildings (a drive-through type of QSR was excluded) with floor areas ranging from $2313 \mathrm{ft}^{2}\left(215 \mathrm{~m}^{2}\right)$ to $4669 \mathrm{ft}^{2}\left(434 \mathrm{~m}^{2}\right)$.

In addition to using the NC3 database, we also reviewed the construction plans of the 11 QSR buildings from the McGraw Hill/F.W. Dodge database. They are referred to as the Dodge drawings in this report. 
Table 2.2. Construction Area Weights for All ASHRAE Building Prototypes and Climate Zones

\begin{tabular}{|c|c|c|c|c|c|c|c|c|c|c|c|c|c|c|c|c|c|c|}
\hline No. & Prototype & $\begin{array}{c}1 \mathrm{~A} \\
\text { moist }\end{array}$ & $\begin{array}{c}2 \mathrm{~A} \\
\text { moist }\end{array}$ & $\begin{array}{l}\text { 2B } \\
\text { dry }\end{array}$ & $\begin{array}{c}3 \mathrm{~A} \\
\text { moist }\end{array}$ & $\begin{array}{l}\text { 3B-CA } \\
\text { coastal }\end{array}$ & $\begin{array}{l}3 \mathrm{~B} \\
\text { dry }\end{array}$ & $\begin{array}{c}3 \mathrm{C} \\
\text { marine }\end{array}$ & $\begin{array}{c}4 \mathrm{~A} \\
\text { moist }\end{array}$ & $\begin{array}{l}\text { 4B } \\
\text { dry }\end{array}$ & $\begin{array}{c}4 \mathrm{C} \\
\text { marine }\end{array}$ & $\begin{array}{c}5 \mathrm{~A} \\
\text { moist }\end{array}$ & $\begin{array}{l}\text { 5B } \\
\text { dry }\end{array}$ & $\begin{array}{c}6 \mathrm{~A} \\
\text { moist }\end{array}$ & $\begin{array}{l}6 \mathrm{~B} \\
\text { dry }\end{array}$ & 7 & 8 & National \\
\hline 1 & Large Office & $0.10 \%$ & $0.33 \%$ & $0.06 \%$ & $0.45 \%$ & $0.17 \%$ & $0.11 \%$ & $0.12 \%$ & $1.14 \%$ & $0.00 \%$ & $0.15 \%$ & $0.45 \%$ & $0.12 \%$ & $0.13 \%$ & $0.00 \%$ & $0.01 \%$ & $0.00 \%$ & $3.35 \%$ \\
\hline 2 & $\begin{array}{l}\text { Medium } \\
\text { Office }\end{array}$ & $0.13 \%$ & $0.82 \%$ & $0.29 \%$ & $0.77 \%$ & $0.30 \%$ & $0.42 \%$ & $0.14 \%$ & $1.20 \%$ & $0.04 \%$ & $0.20 \%$ & $1.07 \%$ & $0.34 \%$ & $0.30 \%$ & $0.04 \%$ & $0.03 \%$ & $0.01 \%$ & $6.09 \%$ \\
\hline 3 & Small Office & $0.08 \%$ & $1.07 \%$ & $0.29 \%$ & $0.97 \%$ & $0.08 \%$ & $0.40 \%$ & $0.08 \%$ & $0.94 \%$ & $0.05 \%$ & $0.12 \%$ & $0.93 \%$ & $0.32 \%$ & $0.24 \%$ & $0.03 \%$ & $0.03 \%$ & $0.00 \%$ & $5.64 \%$ \\
\hline 4 & $\begin{array}{c}\text { Standalone } \\
\text { Retail }\end{array}$ & $0.23 \%$ & $2.23 \%$ & $0.51 \%$ & $2.40 \%$ & $0.33 \%$ & $0.93 \%$ & $0.19 \%$ & $2.56 \%$ & $0.12 \%$ & $0.43 \%$ & $3.45 \%$ & $0.80 \%$ & $0.95 \%$ & $0.09 \%$ & $0.11 \%$ & $0.01 \%$ & $15.35 \%$ \\
\hline 5 & Strip Mall & $0.14 \%$ & $1.00 \%$ & $0.26 \%$ & $1.03 \%$ & $0.17 \%$ & $0.46 \%$ & $0.10 \%$ & $1.01 \%$ & $0.02 \%$ & $0.11 \%$ & $1.03 \%$ & $0.20 \%$ & $0.15 \%$ & $0.02 \%$ & $0.01 \%$ & $0.00 \%$ & $5.71 \%$ \\
\hline 6 & $\begin{array}{l}\text { Primary } \\
\text { School }\end{array}$ & $0.06 \%$ & $0.94 \%$ & $0.17 \%$ & $0.95 \%$ & $0.12 \%$ & $0.33 \%$ & $0.05 \%$ & $0.90 \%$ & $0.03 \%$ & $0.09 \%$ & $0.93 \%$ & $0.23 \%$ & $0.17 \%$ & $0.04 \%$ & $0.02 \%$ & $0.00 \%$ & $5.03 \%$ \\
\hline 7 & $\begin{array}{l}\text { Secondary } \\
\text { School }\end{array}$ & $0.16 \%$ & $1.53 \%$ & $0.23 \%$ & $1.91 \%$ & $0.31 \%$ & $0.52 \%$ & $0.11 \%$ & $2.03 \%$ & $0.06 \%$ & $0.24 \%$ & $2.30 \%$ & $0.44 \%$ & $0.42 \%$ & $0.09 \%$ & $0.08 \%$ & $0.01 \%$ & $10.43 \%$ \\
\hline 8 & Hospital & $0.04 \%$ & $0.48 \%$ & $0.10 \%$ & $0.47 \%$ & $0.14 \%$ & $0.14 \%$ & $0.04 \%$ & $0.62 \%$ & $0.02 \%$ & $0.11 \%$ & $0.82 \%$ & $0.22 \%$ & $0.22 \%$ & $0.02 \%$ & $0.03 \%$ & $0.00 \%$ & $3.47 \%$ \\
\hline 9 & $\begin{array}{l}\text { Outpatient } \\
\text { Health Care }\end{array}$ & $0.04 \%$ & $0.57 \%$ & $0.14 \%$ & $0.58 \%$ & $0.10 \%$ & $0.18 \%$ & $0.06 \%$ & $0.82 \%$ & $0.02 \%$ & $0.18 \%$ & $1.07 \%$ & $0.22 \%$ & $0.34 \%$ & $0.03 \%$ & $0.04 \%$ & $0.00 \%$ & $4.40 \%$ \\
\hline 10 & $\begin{array}{l}\text { Full service } \\
\text { Restaurant }\end{array}$ & $0.01 \%$ & $0.11 \%$ & $0.02 \%$ & $0.11 \%$ & $0.01 \%$ & $0.04 \%$ & $0.01 \%$ & $0.13 \%$ & $0.01 \%$ & $0.01 \%$ & $0.14 \%$ & $0.03 \%$ & $0.03 \%$ & $0.00 \%$ & $0.00 \%$ & $0.00 \%$ & $0.66 \%$ \\
\hline 11 & $\begin{array}{c}\text { Quick- } \\
\text { Service } \\
\text { Restaurant }\end{array}$ & $0.01 \%$ & $0.09 \%$ & $0.02 \%$ & $0.10 \%$ & $0.01 \%$ & $0.05 \%$ & $0.01 \%$ & $0.09 \%$ & $0.01 \%$ & $0.01 \%$ & $0.13 \%$ & $0.03 \%$ & $0.03 \%$ & $0.00 \%$ & $0.00 \%$ & $0.00 \%$ & $0.59 \%$ \\
\hline 12 & Large Hotel & $0.11 \%$ & $0.62 \%$ & $0.13 \%$ & $0.64 \%$ & $0.18 \%$ & $0.61 \%$ & $0.11 \%$ & $0.96 \%$ & $0.04 \%$ & $0.12 \%$ & $0.93 \%$ & $0.20 \%$ & $0.23 \%$ & $0.06 \%$ & $0.04 \%$ & $0.00 \%$ & $4.98 \%$ \\
\hline 13 & $\begin{array}{c}\text { Small } \\
\text { hotel/motel }\end{array}$ & $0.01 \%$ & $0.29 \%$ & $0.03 \%$ & $0.27 \%$ & $0.02 \%$ & $0.09 \%$ & $0.02 \%$ & $0.32 \%$ & $0.02 \%$ & $0.04 \%$ & $0.37 \%$ & $0.09 \%$ & $0.11 \%$ & $0.03 \%$ & $0.02 \%$ & $0.00 \%$ & $1.73 \%$ \\
\hline 14 & Warehouse & $0.33 \%$ & $2.50 \%$ & $0.58 \%$ & $2.91 \%$ & $0.54 \%$ & $1.75 \%$ & $0.15 \%$ & $2.36 \%$ & $0.06 \%$ & $0.42 \%$ & $3.40 \%$ & $0.66 \%$ & $0.42 \%$ & $0.04 \%$ & $0.04 \%$ & $0.00 \%$ & $16.17 \%$ \\
\hline 15 & $\begin{array}{l}\text { High-rise } \\
\text { apartment }\end{array}$ & $1.53 \%$ & $1.52 \%$ & $0.08 \%$ & $0.66 \%$ & $0.37 \%$ & $0.37 \%$ & $0.17 \%$ & $2.52 \%$ & $0.00 \%$ & $0.36 \%$ & $1.17 \%$ & $0.12 \%$ & $0.13 \%$ & $0.02 \%$ & $0.01 \%$ & $0.00 \%$ & $9.02 \%$ \\
\hline \multirow[t]{2}{*}{16} & $\begin{array}{l}\text { Mid-rise } \\
\text { apartment }\end{array}$ & $0.26 \%$ & $1.10 \%$ & $0.09 \%$ & $0.83 \%$ & $0.70 \%$ & $0.17 \%$ & $0.26 \%$ & $1.70 \%$ & $0.02 \%$ & $0.37 \%$ & $1.13 \%$ & $0.32 \%$ & $0.32 \%$ & $0.06 \%$ & $0.03 \%$ & $0.00 \%$ & $7.37 \%$ \\
\hline & Totals & $3.25 \%$ & $15.21 \%$ & $2.99 \%$ & $15.05 \%$ & $3.56 \%$ & $6.56 \%$ & $1.61 \%$ & $19.31 \%$ & $0.52 \%$ & $2.99 \%$ & $19.28 \%$ & $4.34 \%$ & $4.19 \%$ & $0.56 \%$ & $0.52 \%$ & $0.06 \%$ & $100 \%$ \\
\hline
\end{tabular}

Table 2.3. Construction Area Weights for Quick-Service Restaurants

\begin{tabular}{|c|c|c|c|c|c|c|c|c|c|c|c|c|c|c|c|c|}
\hline $\begin{array}{c}\text { 1A } \\
\text { Miami }\end{array}$ & $\begin{array}{c}2 \mathrm{~A} \\
\text { Houston }\end{array}$ & $\begin{array}{c}\text { 2B } \\
\text { Phoenix }\end{array}$ & $\begin{array}{c}3 \mathrm{~A} \\
\text { Atlanta } \\
\end{array}$ & $\begin{array}{c}\text { 3B-CA } \\
\text { Los } \\
\text { Angeles }\end{array}$ & $\begin{array}{c}\text { 3B-other } \\
\text { Las } \\
\text { Vegas }\end{array}$ & $\begin{array}{c}3 \mathrm{C} \\
\text { San } \\
\text { Francisco }\end{array}$ & $\begin{array}{c}4 \mathrm{~A} \\
\text { Baltimore }\end{array}$ & $\begin{array}{c}4 \mathrm{~B} \\
\text { Albuquerque }\end{array}$ & $\begin{array}{c}4 \mathrm{C} \\
\text { Seattle }\end{array}$ & $\begin{array}{c}5 \mathrm{~A} \\
\text { Chicago } \\
\end{array}$ & $\begin{array}{c}5 \mathrm{~B} \\
\text { Denver }\end{array}$ & $\begin{array}{c}6 \mathrm{~A} \\
\text { Minneapolis }\end{array}$ & $\begin{array}{c}\text { 6B } \\
\text { Helena } \\
\end{array}$ & $\begin{array}{c}7 \\
\text { Duluth }\end{array}$ & $\begin{array}{c}8 \\
\text { Fairbanks }\end{array}$ & Total \\
\hline $1.37 \%$ & $15.70 \%$ & $3.41 \%$ & $17.41 \%$ & $5.38 \%$ & $5.38 \%$ & $1.19 \%$ & $15.19 \%$ & $2.39 \%$ & $0.85 \%$ & $21.84 \%$ & $4.44 \%$ & $4.27 \%$ & $0.51 \%$ & $0.68 \%$ & $0.00 \%$ & $100 \%$ \\
\hline
\end{tabular}




\subsubsection{Prototype Building Architectural Features}

The prototype building is defined to have two thermal zones: the kitchen and the dining area. The authors assumed that other spaces such as restrooms, offices, and storage spaces do not have separate air temperature set points and HVAC system; therefore, they are included in the two modeled zones. The floor areas of the 38 post-1980 QSRs in the CBECS range from $1100 \mathrm{ft}^{2}\left(102 \mathrm{~m}^{2}\right)$ to $12,000 \mathrm{ft}^{2}\left(1115 \mathrm{~m}^{2}\right)$; and those of the 11 buildings in the NC3 database range from $2313 \mathrm{ft}^{2}\left(215 \mathrm{~m}^{2}\right)$ to $4669 \mathrm{ft}^{2}\left(434 \mathrm{~m}^{2}\right)$. The authors decide to adopt the size of the single-story DOE Reference QSR Building (i.e., $2500 \mathrm{ft}^{2}\left[232 \mathrm{~m}^{2}\right]$ ) for this study. This size is regarded as representative of the buildings housing large-volume, burger-based QSRs.

According to the CBECS data, a rectangular footprint is very common design for QSRs (see Figure 2.2). The average building footprint aspect ratio of QSRs from the NC3 database is 2.3; and one of building floor plans is shown in Figure 2.3. The design experience of the authors who have worked with different QSRs also confirm that it is very common to design a QSR building with an aspect ratio of 2 and with roughly equal spaces for the dining and food-preparation areas. Therefore, rather than adopting the DOE Reference QSR design, we selected the prototype building floor plan shown in Figure 2.4.

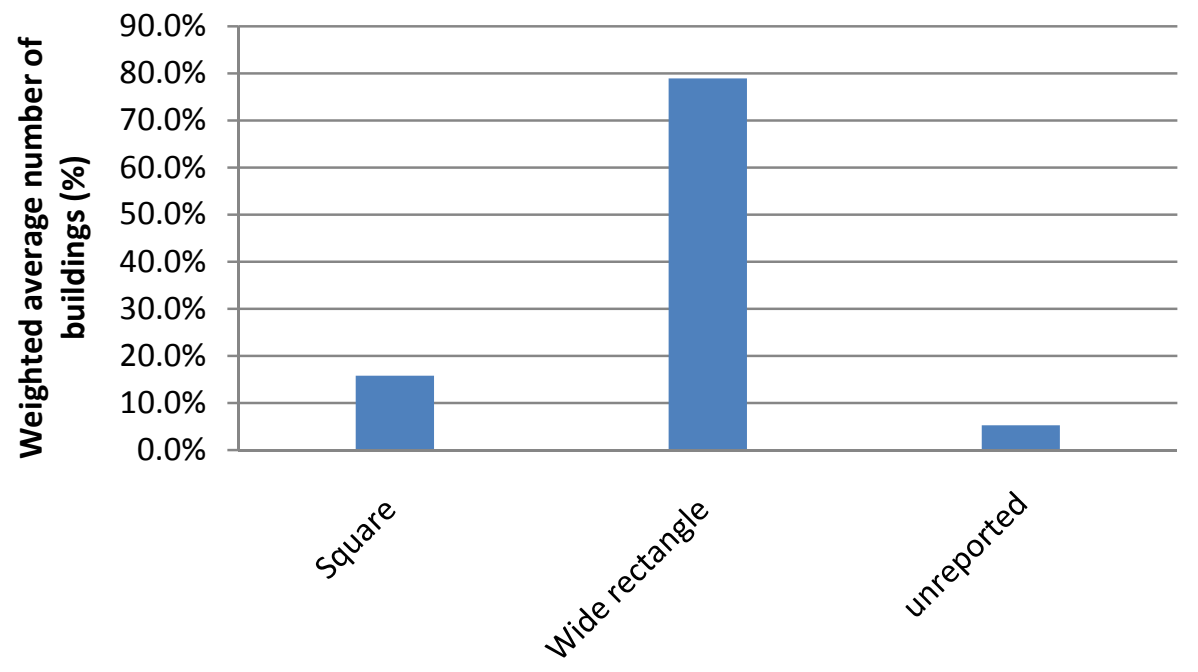

Figure 2.2. Building Shape Distribution of Post-1980 QSR Buildings (CBECS 2003) 


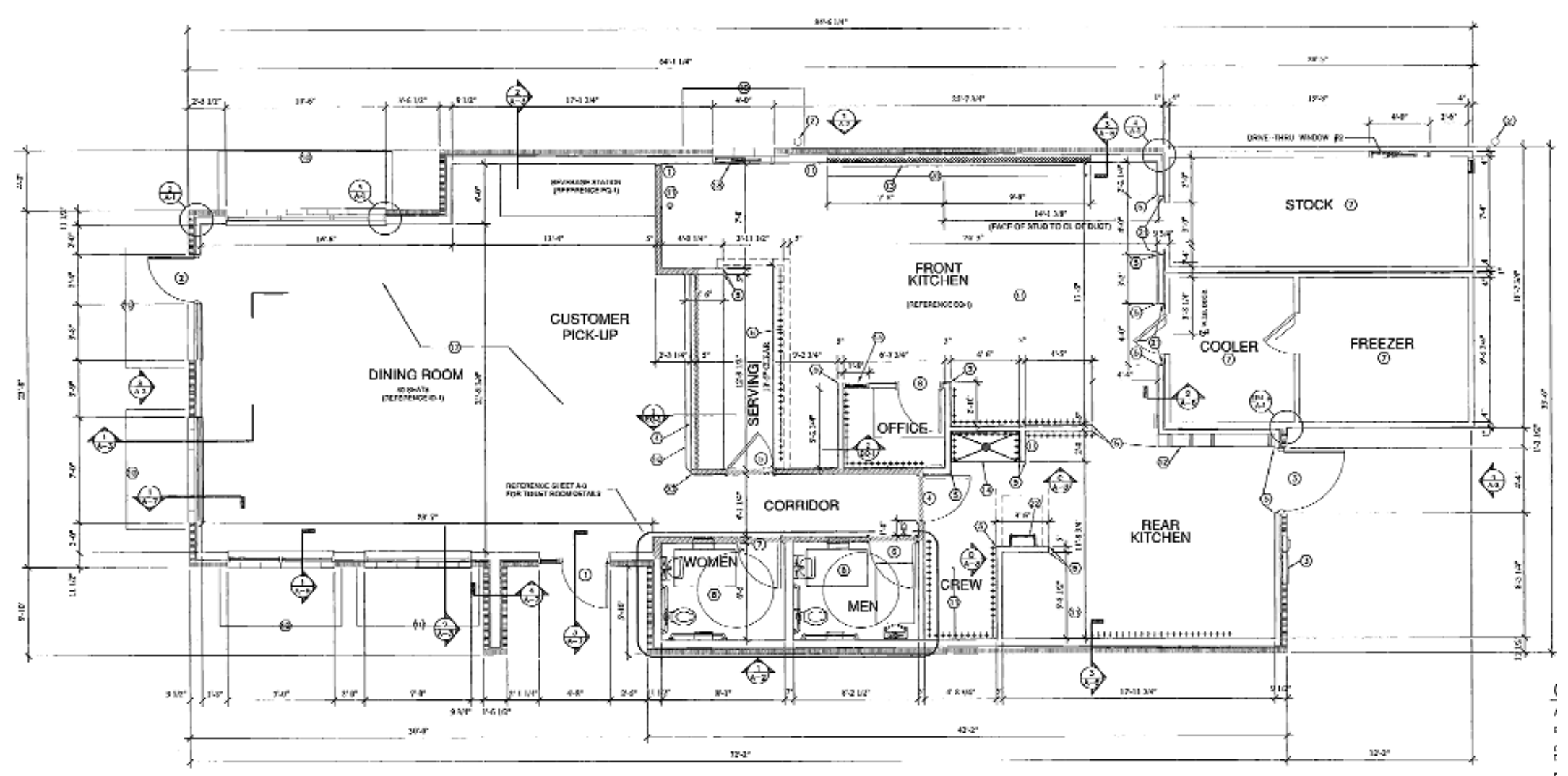

Figure 2.3. Example of a QSR Building Floor Plan from the Dodge Drawings 


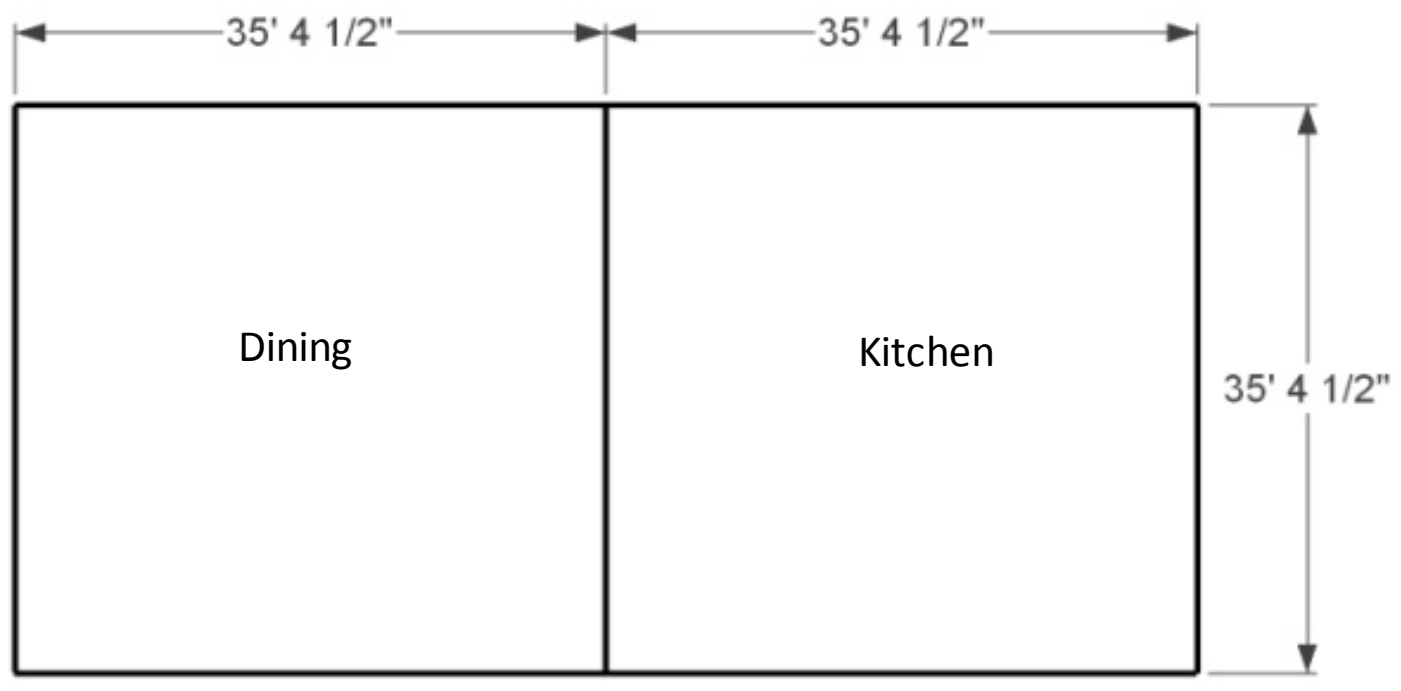

Figure 2.4. Thermal Zones of the QSR Prototype Building

The CBECS has nine types of building roofs and nine types of exterior building walls, which are different from those defined in Standard 90.1-2004. When developing the DOE Reference Buildings, PNNL developed a mapping method between the two classifications (Winiarski et al. 2007). The results of this effort are shown in Table 2.4 and Table 2.5. Because the tables still do not clearly indicate a typical envelope for QSRs in the CBECS in terms of the classifications defined in Standard 90.1-2004, we conducted further reviews of the Dodge drawings and the NC3 Database. Because all 11 QSRs in the Dodge database have flat roofs, the authors decided to use a flat roof with a plenum for the prototype building in this project. According to Standard 90.1-2004, the roof is defined as insulation entirely above deck. In addition, all 11 QSR buildings in the NC3 Database were designed with wood-framed wall structures and slab-on-grade floors. Therefore, we used the same wall and floor construction types in the DOE Reference QSR Building and in this study.

Fenestration is another important component of the building envelope in terms of energy consumption. According to the CBECS, QSRs have a wide range of window-to-wall area fractions as shown in Figure 2.5. In the NC3 database, the average window-to-wall ratio (WWR) of the 11 QSR buildings is $12 \%$. After taking both data sources into account, we chose the WWR of $14 \%$ - used in the DOE's Reference QSR Building - as a reasonable assumption.

According to the Dodge drawings, most QSRs use manufactured windows in punch style. The drawings also indicate that the average height of the windows is about $6 \mathrm{ft} 8 \mathrm{in}$. $(2.03 \mathrm{~m})$ and the average location of the sill as $1.5 \mathrm{ft}(0.46 \mathrm{~m})$ above the building floor. Although most quick-service restaurants provide drive-through services, the glazing areas of the drive-through windows in the kitchen zone are normally small compared to the view windows in the dining area. To simplify the model, we assumed the kitchen zone has no windows. Therefore four windows, each with a size of $6 \mathrm{ft} 8 \mathrm{in}$. by $6 \mathrm{ft}(2.03 \mathrm{~m}$ by $1.83 \mathrm{~m}$ ), are evenly distributed on the south façade and three windows of the same size are placed on the east and west façades of the dining zone. Figure 2.6 shows the 3-D rendering of the developed prototype QSR building. 
Table 2.4. Relationship of CBECS Roof Descriptions and Standard 90.1-2004 Roof Construction

\begin{tabular}{|c|c|c|c|c|}
\hline \multirow[b]{2}{*}{ CBECS Roof Descriptions } & \multirow[b]{2}{*}{$\begin{array}{c}\text { Percentage } \\
\text { (CBECS 2003) }\end{array}$} & \multicolumn{3}{|c|}{$\begin{array}{l}\text { ASHRAE Standard 90.1-2004 } \\
\text { Roof Construction }\end{array}$} \\
\hline & & $\begin{array}{c}\text { Insulation } \\
\text { Entirely Above } \\
\text { Deck }\end{array}$ & $\begin{array}{c}\text { Metal } \\
\text { Building }\end{array}$ & $\begin{array}{l}\text { Attic and } \\
\text { Other }\end{array}$ \\
\hline Asphalt, Fiberglass, Other (AFO) & $23.70 \%$ & $\mathrm{x}$ & & $\mathrm{x}$ \\
\hline Built-Up & $15.80 \%$ & $\mathrm{x}$ & & \\
\hline Concrete & $5.30 \%$ & & & $\mathrm{x}$ \\
\hline Metal Surfacing & $10.50 \%$ & & $\mathrm{x}$ & $\mathrm{x}$ \\
\hline No One Major Type & $0.00 \%$ & & & \\
\hline Other & $0.00 \%$ & & & \\
\hline Plastic, Rubber, Synthetic (PRS) & $42.10 \%$ & $\mathrm{x}$ & & $\mathrm{x}$ \\
\hline Slate, Tile Shingles (STS) & $2.60 \%$ & & & $\mathrm{x}$ \\
\hline Wood Shingles, Shakes, Other (WSSO) & $0.00 \%$ & & & $\mathrm{x}$ \\
\hline
\end{tabular}

Table 2.5. Relationship of CBECS Wall Descriptions and Standard 90.1-2004 Wall Construction

\begin{tabular}{|c|c|c|c|c|c|}
\hline \multirow[b]{2}{*}{ CBECS Wall Descriptions } & \multirow[b]{2}{*}{$\begin{array}{c}\text { Percentage } \\
\text { (CBECS 2003) }\end{array}$} & \multicolumn{4}{|c|}{ ASHRAE Standard 90.1-2004 Wall Construction } \\
\hline & & Mass & $\begin{array}{c}\text { Metal } \\
\text { Building }\end{array}$ & $\begin{array}{l}\text { Steel- } \\
\text { Framed }\end{array}$ & $\begin{array}{l}\text { Wood } \\
\text { Framed and } \\
\text { Other }\end{array}$ \\
\hline Brick, Stone, Stucco (BSS) & $63.2 \%$ & $\mathrm{x}$ & $\mathrm{x}$ & $\mathrm{x}$ & $\mathrm{x}$ \\
\hline Concrete, Block or Poured (CBP) & $15.8 \%$ & $\mathrm{x}$ & & & \\
\hline Pre-Cast Concrete Panels (PCCP) & $2.6 \%$ & $\mathrm{x}$ & & & \\
\hline Sheet metal panels (SMP) & $0.0 \%$ & & $\mathrm{x}$ & & \\
\hline Siding, Shingles, Tiles, Shakes (SSTS) & $13.2 \%$ & & & $\mathrm{x}$ & $\mathrm{x}$ \\
\hline Decorative or Construction Glass & $0.0 \%$ & & & $\mathrm{x}$ & \\
\hline Window or Vision Glass & $2.6 \%$ & & & $\mathrm{x}$ & \\
\hline No one major type & $0.0 \%$ & Unknown & Unknown & Unknown & Unknown \\
\hline Other & $2.6 \%$ & Unknown & Unknown & Unknown & Unknown \\
\hline
\end{tabular}




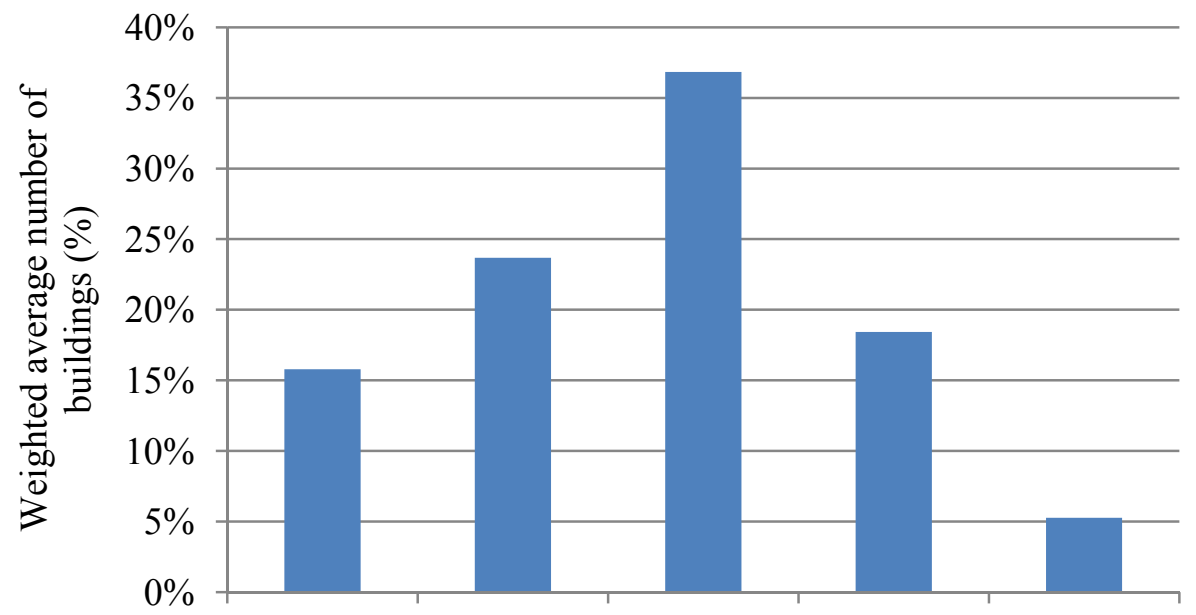

$10 \%$ or less 11 to $25 \% 26$ to $50 \% 51$ to $75 \%$ unreported

Figure 2.5. Window-to-Wall Area Fraction of Post-1980 QSR Buildings (CBECS 2003)

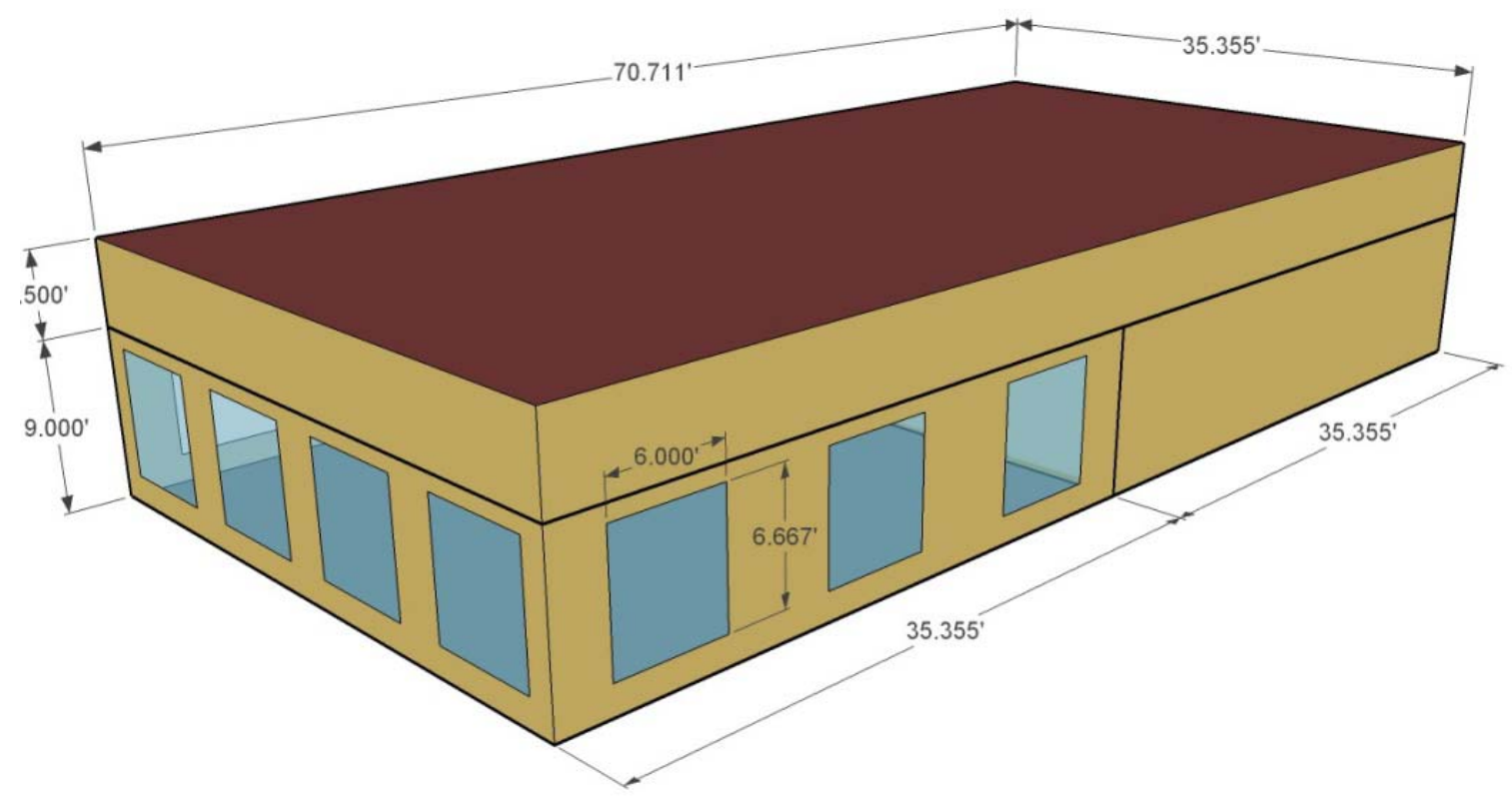

Figure 2.6. Axonometric View of the Prototype QSR Building

\subsubsection{Prototype Building Operating Hours}

CBECS survey data provides a range of business open hours in QSRs (Figure 2.7), showing over 60\% surveyed QSRs operates between 85 to 167 hours weekly. Using CBECS data and feedback from members of the Retail Energy Alliance Restaurant Subcommittee (DOE 2010a), the prototype building has the business hours from 6 a.m. to midnight Monday through Friday and from 7 a.m. to midnight Saturday and Sunday, resulting in a total of 128 business open hours per week. The extended hours for staff members for preparation and cleaning are one hour before and one hour after the business open hours. Figure 2.8 illustrates the weekly schedules of the building occupancy. 


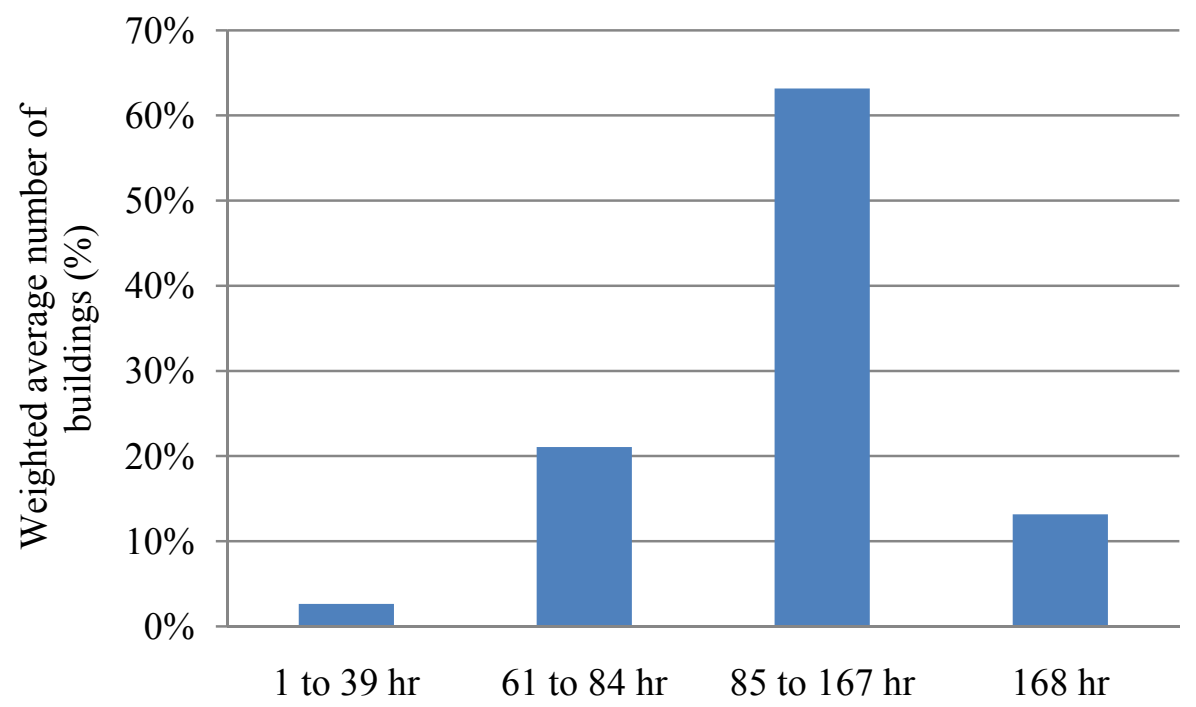

Figure 2.7. Building Weekly Operating Hours of Post-1980 QSR Buildings (CBECS 2003)

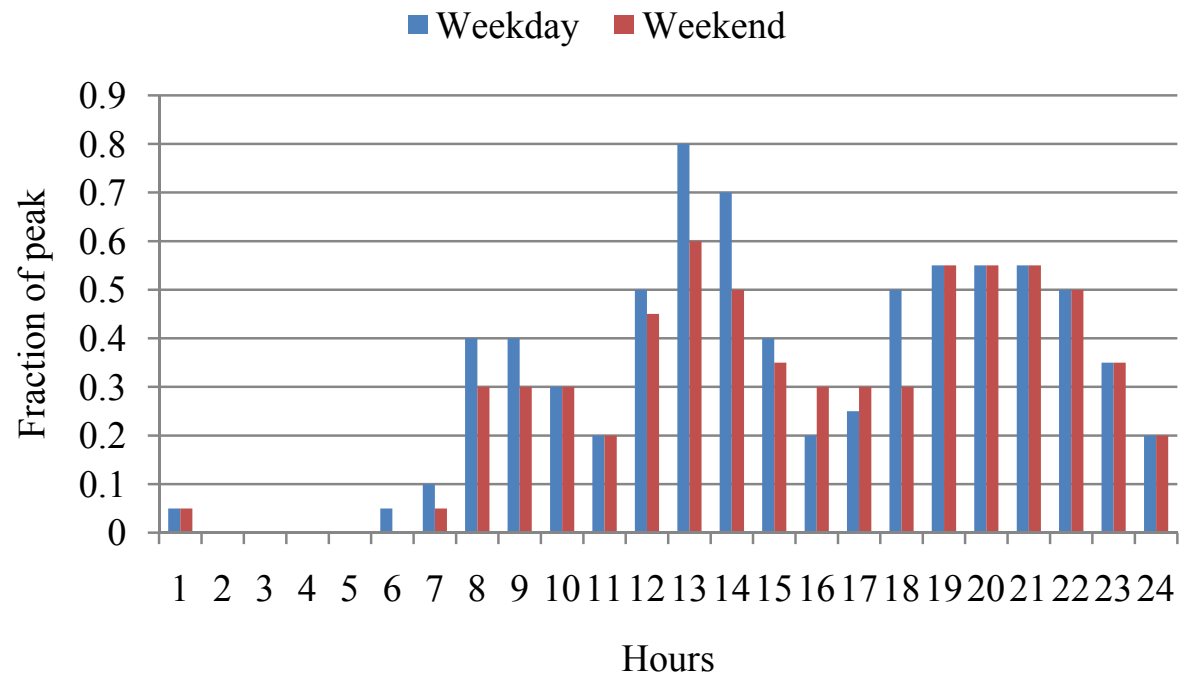

Figure 2.8. Prototype QSR Occupancy Schedules 


\subsection{Quick-Service Restaurant Baseline Models}

The basic building characteristics of the QSR buildings are defined in Chapter 2.0. Those characteristics do not change with the climate locations, and the same characteristics are used in both baseline and the energy efficient building models. This chapter presents the baseline QSR building models in terms of their envelope, air infiltration, internal and external loads, commercial kitchen appliances, HVAC system and equipment, and service water heating. These characteristics are usually climate-specific, and they also may change for the baseline model and the energy efficient models. The baseline building components regulated by Standard 90.1-2004 are assumed to "just meet" the minimum prescriptive requirements of the standard. Components not regulated by the standard are assumed to follow typical design practice.

\subsection{Baseline Building Envelope Characteristics}

The opaque envelope components of the QSR prototype building were identified in Section 2.4.2 as a slab-on-grade floor, wood-framed exterior walls, and roof type of insulation entirely above the deck. The type, location, and size of the fenestration components were defined also. The baseline building envelope characteristics were developed to meet the minimum prescriptive requirements of Standard 90.1-2004 Section 5.3, "Prescriptive Building Envelope Option" (ANSI/ASHRAE/IESNA 2004). Values shown for the non-residential category and conditioned spaces in Standard 90.1-2004 are used. The EnergyPlus program calculates the U-factor of opaque assemblies by defining the material properties of each layer of the construction. This method also is used in this report to properly prepare the model input for the baseline envelope construction. Sections 3.1.1 through 3.1.5 describe the assumptions used for modeling the baseline building envelope components, including the exterior walls, roofs, slab-on-grade floors, fenestration, air infiltration, and roof absorptance.

\subsubsection{Exterior Walls}

The exterior walls of the QSR baseline building are wood-framed with exterior stucco cladding. Fiberglass batt insulation is placed within the stud cavity and additional rigid insulation may be used to meet climate zone specific requirements. The exterior wall includes the following layers:

- Exterior air film, R-0.17 $\mathrm{ft}^{2} \cdot \mathrm{F} \cdot \mathrm{h} / \mathrm{Btu}\left(0.03 \mathrm{~K} \cdot \mathrm{m}^{2} / \mathrm{W}\right)$

- 0.75-in. (19-mm) thick stucco, R-0.08 $\mathrm{ft}^{2} \cdot \mathrm{F} \cdot \mathrm{h} / \mathrm{Btu}\left(0.01 \mathrm{~K} \cdot \mathrm{m}^{2} / \mathrm{W}\right)$

- 0.625-in. (16-mm) thick gypsum board, R-0.56 $\mathrm{ft}^{2} \cdot \mathrm{F} \cdot \mathrm{h} / \mathrm{Btu}\left(0.10 \mathrm{~K} \cdot \mathrm{m}^{2} / \mathrm{W}\right)$

- 2-in by 4 -in. (50-mm x 100-mm) wood studs at 16 in. (400 mm) on center with R-13 $\mathrm{ft}^{2} \cdot \mathrm{F} \cdot \mathrm{h} / \mathrm{Btu}$ $\left(2.3 \mathrm{~K} \cdot \mathrm{m}^{2} / \mathrm{W}\right)$ fiberglass batt insulation in the stud cavity

- Additional board insulation (thickness and R-value vary by climate)

- 0.625-in. (16-mm) thick gypsum board, R-0.56 $\mathrm{ft}^{2} \cdot \mathrm{F} \cdot \mathrm{h} / \mathrm{Btu}\left(0.10 \mathrm{~K} \cdot \mathrm{m}^{2} / \mathrm{W}\right)$

- Interior air film, R-0.68 $\mathrm{ft}^{2} \cdot \mathrm{F} \cdot \mathrm{h} / \mathrm{Btu}\left(0.12 \mathrm{~K} \cdot \mathrm{m}^{2} / \mathrm{W}\right)$.

The baseline R-values for insulated assemblies are from Standard 90.1-2004 Appendix A (Rated RValue of Insulation and Assembly U-Factor, C-Factor, And F-Factor Determination) 
(ANSI/ASHRAE/IESNA 2004). The insulation R-values from Table A3.4 in Appendix A of Standard 90.1-2004 are used to select a wall assembly that just meets the maximum U-factor required in Tables 5.5.1 through 5.5.8 of the standard for different climate zones. The required insulation R-values and assembly U-factors are summarized in Table 3.1 .

Table 3.1. Baseline Thermal Requirements for Exterior Above-Grade, Wood-Framed Walls

\begin{tabular}{ccccc}
\hline \multirow{2}{*}{$\begin{array}{c}\text { Climate } \\
\text { Zone }\end{array}$} & \multicolumn{2}{c}{$\begin{array}{c}\text { Assembly maximum } \\
\text { U-factor }\end{array}$} & \multicolumn{2}{c}{$\begin{array}{c}\text { Insulation minimum } \\
\mathrm{R} \text {-value }\end{array}$} \\
\cline { 2 - 5 } & $\mathrm{Btu} / \mathrm{h} \cdot \mathrm{ft}^{2} \cdot{ }^{\circ} \mathrm{F}$ & $\mathrm{W} / \mathrm{m}^{2} \bullet \mathrm{K}$ & $\mathrm{h} \cdot \mathrm{ft}^{2} \cdot \mathrm{F} / \mathrm{Btu}$ & $\mathrm{m}^{2} \bullet \mathrm{K} / \mathrm{W}$ \\
\hline 1 & 0.089 & 0.50 & 13 & 2.3 \\
2 & 0.089 & 0.50 & 13 & 2.3 \\
3 & 0.089 & 0.50 & 13 & 2.3 \\
4 & 0.089 & 0.50 & 13 & 2.3 \\
5 & 0.089 & 0.50 & 13 & 2.3 \\
6 & 0.089 & 0.50 & 13 & 2.3 \\
7 & 0.089 & 0.50 & 13 & 2.3 \\
8 & 0.051 & 0.29 & $13+7.5$ c.i. & $2.3+1.3$ c.i. \\
\hline c.i. = continuous insulation & \multicolumn{3}{c}{} \\
\hline
\end{tabular}

\subsubsection{Roofs}

The baseline QSR building has a flat roof that consists of a roof membrane over rigid insulation, uninterrupted by framing, over a structural metal deck. The roof construction is defined with the following layers:

- Exterior air film, R-0.17 h. $\cdot \mathrm{ft}^{2} \cdot{ }^{\circ} \mathrm{F} / \mathrm{Btu}\left(0.03 \mathrm{~K} \cdot \mathrm{m}^{2} / \mathrm{W}\right)$

- Continuous rigid insulation (thickness and R-value vary by climate)

- Metal deck, R-0.00 h. $\mathrm{ft}^{2} \cdot{ }^{\circ} \mathrm{F} / \mathrm{Btu}\left(0.00 \mathrm{~K} \cdot \mathrm{m}^{2} / \mathrm{W}\right)$

- Interior air film heat flow up, R-0.61 h/ $\mathrm{ft}^{2} \cdot{ }^{\circ} \mathrm{F} / \mathrm{Btu}\left(0.11 \mathrm{~K} \cdot \mathrm{m}^{2} / \mathrm{W}\right)$.

Roof insulation R-values are set to match the maximum roof $\mathrm{U}$-factor requirements in Tables 5.5.1 through 5.5.8 of Standard 90.1-2004 for different climate zones. The baseline insulation R-values and assembly U-factors are shown in Table 3.2. Standard 90.1-2004 does not specify either roof reflectivity or emittance. In the prototype QSR building, the roof exterior finish was chosen to be a single-ply membrane of ethylene-propylene-diene-terpolymer membrane (EPDM). A grey EPDM is used in the baseline, and it has a solar reflectance of 0.23 and a thermal emittance of 0.87 (LBNL 2010a). 
Table 3.2. Baseline Thermal Requirements for Roofs with Insulation Entirely Above Deck

\begin{tabular}{|c|c|c|c|c|}
\hline \multirow{2}{*}{$\begin{array}{c}\text { Climate } \\
\text { Zone }\end{array}$} & \multicolumn{2}{|c|}{$\begin{array}{c}\text { Assembly maximum } \\
\text { U-factor }\end{array}$} & \multicolumn{2}{|c|}{$\begin{array}{c}\text { Insulation minimum } \\
\text { R-value } \\
\text { (continuous insulation) }\end{array}$} \\
\hline & $\mathrm{Btu} / \mathrm{h} \cdot \mathrm{ft}^{2} \cdot{ }^{\circ} \mathrm{F}$ & $\mathrm{W} / \mathrm{m}^{2} \cdot \mathrm{K}$ & $\mathrm{h} \cdot \mathrm{ft}^{2} \cdot \mathrm{F} / \mathrm{Btu}$ & $\mathrm{m}^{2} \cdot \mathrm{K} / \mathrm{W}$ \\
\hline 1 & 0.063 & 0.36 & 15 & 2.6 \\
\hline 2 & 0.063 & 0.36 & 15 & 2.6 \\
\hline 3 & 0.063 & 0.36 & 15 & 2.6 \\
\hline 4 & 0.063 & 0.36 & 15 & 2.6 \\
\hline 5 & 0.063 & 0.36 & 15 & 2.6 \\
\hline 6 & 0.063 & 0.36 & 15 & 2.6 \\
\hline 7 & 0.063 & 0.36 & 15 & 2.6 \\
\hline 8 & 0.048 & 0.27 & 20 & 3.5 \\
\hline
\end{tabular}

\subsubsection{Slab-On-Grade Floors}

The assembly for the ground floor in the baseline QSRs is a single layer of 6-in. (150-mm) concrete slab floor poured directly onto prepared ground (i.e., slab-on-grade construction). Modeled below the slab is $12 \mathrm{in}$. $(300 \mathrm{~mm})$ of soil with a conductivity of $0.75 \mathrm{Btu} / \mathrm{h} \cdot \mathrm{ft}^{2} \cdot{ }^{\circ} \mathrm{F}\left(4.25 \mathrm{~W} / \mathrm{m}^{2} \cdot \mathrm{K}\right)$. In contrast to the $\mathrm{U}$-factor for other envelope assemblies, the F-factor is set to match the minimum requirements for unheated slab-on-grade floors in Tables 5.5.1 through 5.5.8 of Standard 90.1 2004, based on climate. The F-factor is expressed as the conductance of the surface per unit length of building perimeter. Chapter 5 of the standard also provides the corresponding R-values of the vertical insulation when required (e.g., in Climate Zone 8 as shown in Table 3.3). This continuous insulation is typically applied directly to the slab exterior, extending downward from the top of the slab for the distance specified in the tables.

One of the advanced features of the EnergyPlus program is that the calculations of the ground conductive heat transfer through ground-contact surfaces (i.e., slab-on-grade floors) are three-dimensional rather than the simplified one-dimensional calculations used in other simulation programs (DOE-2). To use this method, the appropriate ground temperature is determined by the Slab program, which is one of the preprocessors under Auxiliary EnergyPlus Programs. Then, the calculated custom monthly average ground temperatures are manually transferred directly into EnergyPlus for each of 16 climate locations.

The Slab program requires the following key inputs to calculate ground temperatures:

- Slab material and soil density

- Building height

- Indoor average temperature set point

- R-value and depth of vertical insulation (if presented)

- Thickness of slab-on-grade

- The floor area to perimeter length ratio for this slab

- Distance from edge of slab to domain edge. 
Table 3.3. Baseline Thermal Requirements for a Slab-on-Grade Unheated Floor

\begin{tabular}{ccccc}
\hline \multirow{2}{*}{$\begin{array}{c}\text { Climate } \\
\text { Zone }\end{array}$} & \multicolumn{3}{c}{ Assembly Maximum F-factor } & \multicolumn{2}{c}{ Insulation R-value for } \\
\cline { 2 - 5 } & $\mathrm{Btu} / \mathrm{h} \cdot \mathrm{ft} \cdot{ }^{\circ} \mathrm{F}$ & $\mathrm{W} / \mathrm{m} \cdot \mathrm{K}$ & $\mathrm{h} \bullet \mathrm{ft}^{2} \bullet \mathrm{F} / \mathrm{Btu}$ & $\mathrm{m}^{2} \bullet \mathrm{K} / \mathrm{W}$ \\
\hline 1 & 0.73 & 1.26 & $\mathrm{NR}$ & $\mathrm{NR}$ \\
2 & 0.73 & 1.26 & $\mathrm{NR}$ & $\mathrm{NR}$ \\
3 & 0.73 & 1.26 & $\mathrm{NR}$ & $\mathrm{NR}$ \\
4 & 0.73 & 1.26 & $\mathrm{NR}$ & $\mathrm{NR}$ \\
5 & 0.73 & 1.26 & $\mathrm{NR}$ & $\mathrm{NR}$ \\
6 & 0.73 & 1.26 & $\mathrm{NR}$ & $\mathrm{NR}$ \\
7 & 0.73 & 1.26 & $\mathrm{NR}$ & $\mathrm{NR}$ \\
8 & 0.54 & 0.94 & 10 & 1.76 \\
\hline $\mathrm{NR}=$ no requirement & \multicolumn{5}{c}{} \\
\hline \multicolumn{7}{c}{} \\
\hline
\end{tabular}

\subsubsection{Fenestration}

The size and style of the fenestration component of the prototype building was determined in Section 2.4.2. Although the window requirements in Standard 90.1-2004 are defined by the overall properties of U-factor and solar-heat-gain coefficient (SHGC), EnergyPlus requires the thermal/optical properties to be defined layer by layer for the window assembly. It is challenging to manually find a window construction that matches given $\mathrm{U}$-factor and SHGC values exactly. To address this challenge, NREL developed a hypothetical glass library for EnergyPlus by creating glazing options to represent windows that match Standard 90.1-2004 performance requirements. These glazing options allow the baseline values to fall within 0.01 of the required U-factor and SHGC for all climate zones.

Chapter 5 of Standard 90.1- 2004 lists the U-factor and SHGC requirements based on climate zone, WWR, and window operator type (fixed or operable). Based on an estimated weighting of $1.6 \%$ operable and $98.4 \%$ fixed windows, ${ }^{1}$ baseline window U-factors and SHGCs are determined to match the fenestration performance criteria outlined in Tables 5.5.1 through 5.5.8 of Standard 90.1- 2004 (ANSI/ASHRAE/IESNA 2004) for different climate zones. These required performance values are shown in Table 3.4. These values are from the $10.1 \%$ to $20.0 \%$ WWR category. The effects of window frame and dividers are not modeled explicitly, rather the frames and dividers are included in the overall U-factor baseline values.

Visible transmittance (VT) is an additional quality of the fenestration. VT has no direct impact on building loads or energy consumption, but it impacts the performance of daylighting control systems where present. The baseline buildings do not have daylighting dimming controls so VT has no impact on the simulation results for the baseline. There is no prescriptive requirement for VT in Standard 90.12004. For the baseline fenestration, VT values are from window constructions in the hypothetical glass window library that meet the desired U-factor and SHGC. The VT values are approximately the same as the SHGC values.

\footnotetext{
${ }^{1}$ The ASHRAE SSPC 90.1 Envelope Subcommittee provided the estimated weighting factor based on the Ducker Fenestration Market Data.
} 
Table 3.4. Baseline Thermal Requirements for Fenestration

\begin{tabular}{|c|c|c|c|}
\hline \multirow{2}{*}{$\begin{array}{l}\text { Climate } \\
\text { Zone }\end{array}$} & \multicolumn{2}{|c|}{$\begin{array}{c}\text { Assembly maximum } \\
\text { U-factor }\end{array}$} & \multirow[b]{2}{*}{ SHGC } \\
\hline & $\mathrm{Btu} / \mathrm{h} \cdot \mathrm{ft}^{2} \cdot{ }^{\circ} \mathrm{F}$ & $\mathrm{W} / \mathrm{m}^{2} \cdot \mathrm{K}$ & \\
\hline 1 & 1.22 & 6.93 & 0.25 \\
\hline 2 & 1.22 & 6.93 & 0.25 \\
\hline $3 \mathrm{~A}, 3 \mathrm{~B}$ & 0.57 & 3.24 & 0.25 \\
\hline $3 \mathrm{C}$ & 1.22 & 6.93 & 0.39 \\
\hline 4 & 0.57 & 3.24 & 0.39 \\
\hline 5 & 0.57 & 3.24 & 0.39 \\
\hline 6 & 0.57 & 3.24 & 0.39 \\
\hline 7 & 0.57 & 3.24 & 0.49 \\
\hline 8 & 0.46 & 2.61 & 0.45 \\
\hline
\end{tabular}

\subsubsection{Air Infiltration through Building Envelope Leakage}

Standard 90.1-2004 does not specify a requirement for maximum air infiltration rate. Building air infiltration is addressed only indirectly in the standard through the requirements for building envelope sealing, fenestration and door air leakage, etc. For this analysis, the infiltration rate was assumed to be $1.8 \mathrm{cfm} / \mathrm{ft}^{2}\left(9.14 \mathrm{E}-3 \mathrm{~m} / \mathrm{s} \cdot \mathrm{m}^{2}\right)$ of above-grade envelope surface area at $0.3 \mathrm{in}$. water column (w.c.) (75 Pa) based on the study by the National Institute of Standards and Technologies (Emmerich et al. 2005).

The EnergyPlus program offers three methods for addressing infiltration: the constant infiltration method (the EnergyPlus default); the DOE-2 methodology, which accounts for wind-driven pressure differences; and the BLAST methodology, which accounts for both wind-driven and stack-driven pressure differences. Based on the results of PNNL's study on infiltration modeling methodology, the $D O E-2$ method was used in this project.

PNNL has developed the following methodology to convert the infiltration rate at 0.3 in. w.c. (75 Pa) to a corresponding wind-driven design infiltration rate input in EnergyPlus:

Step 1: Calculate the average wind-driven building pressure on all walls of a building with a wind velocity calculated at the roof line and normal to one wall of the building using existing wind pressure formulations (Swami and Chandra 1987).

Step 2: Integrate the positive wind-driven building pressure for all angles of wind to get an average positive wind pressure across all wall surfaces as a function of wind velocity. This step is necessary because the wind speed correlations in EnergyPlus are independent of direction.

Step 3: Calculate the infiltration in the building at an average surface pressure from Step 2 and a reference wind speed at the roof line (e.g., $10 \mathrm{mph}$ ) by multiplying the infiltration at $0.3 \mathrm{in}$. w.c. (75 Pa) whole building pressure difference by the ratio of the average wind pressure from Step 2 to 0.3 in. w.c. $(75 \mathrm{~Pa})$, as modified using a flow exponent 0.65 . This step provides the average infiltration rate across the wall surfaces based on the wind speed measured at the roof line. 
Step 4: Adjust the calculated infiltration rate from Step 3 so that it can be correctly used as EnergyPlus input by multiplying it by the ratio of the wind speed at the roof line to the average wind speed impinging on a building wall with outward surface normal anti-parallel to the wind direction. This ratio can be calculated using a power-law wind profile based on the same site terrain as in the EnergyPlus model. This step is necessary because the infiltration calculations in EnergyPlus use the wind speed at the center height of each exterior wall above ground.

Following the above methodology, the EnergyPlus input design infiltration is calculated as $0.20 \mathrm{cfm} / \mathrm{ft}^{2}\left(1.02 \mathrm{E}-3 \mathrm{~m}^{3} / \mathrm{s}-\mathrm{m}^{2}\right)$ of above-grade exterior wall surface area, equivalent to the base infiltration rate of $1.8 \mathrm{cfm} / \mathrm{ft}^{2}\left(9.14 \mathrm{E}-3 \mathrm{~m}^{3} / \mathrm{s}-\mathrm{m}^{2}\right)$ of above-grade envelope surface area at $0.3 \mathrm{in}$. w.c. $(75 \mathrm{~Pa})$. In addition, an infiltration schedule is input in EnergyPlus to vary the peak infiltration rate calculated above with HVAC fan on/off operation. The schedule assumes full infiltration when the HVAC system is switched "off" and 25\% infiltration when the HVAC system is switched "on".

\subsection{Internal and External Loads}

Internal loads include heat generated from occupants, lights, cooking appliances, and other process loads, such as beverage machines, refrigeration, office equipment, etc.. In this study, external loads refer to the exterior lighting energy use only. Modeling the energy impacts of the building internal loads using EnergyPlus requires assumptions about the building internal load intensity and operation schedules. For occupancy loads, the load intensity refers to the peak occupancy for a typical day. For interior lighting loads, the load intensity refers to the peak power density. Because cooking-related equipment loads account for a crucial share of the total building energy use, they are separately addressed in Section 3.3.

\subsubsection{People}

To define the minimum ventilation rate for acceptable indoor air quality, ASHRAE Standard 62.12004, Table 6-1, "Minimum Ventilation Rates in Breathing Zone," provides default occupant densities for various occupancy categories. The default occupancy for the restaurant dining category is 70 people per $1000 \mathrm{ft}^{2}$ of floor area or approximately one person per $100 \mathrm{~m}^{2}$. This results in peak occupant number of 88 in the dining zone. Standard 62.1-2004 does not provide default occupancy for commercial kitchens, thus, based on common practice, we assume six people are in the kitchen zone. The occupancy schedule profiles for a typical Monday through Friday workday and weekend workday are shown in Figure 2.8. These profiles are based on DOE's Reference QSR Building with minor modifications to match the business open hour of the prototype QSR.

\subsubsection{Interior Lighting}

The baseline lighting system is assumed to be a system that meets the maximum allowed lighting power density (LPD) requirements in Standard 90.1- 2004, Table 9.5.1, "Lighting Power Densities Using the Building Area Method." Ambient LPD for the entire building is input at an average of $1.44 \mathrm{~W} / \mathrm{ft}^{2}$ $\left(15.5 \mathrm{~W} / \mathrm{m}^{2}\right)$ for all areas as shown in Table 3.5. It is derived based on lighting fixture types, lamp types, and number of lights used in each building space type covered by Table 9.6.1 in Standard 90.1-2004. The space types represented in the QSR prototype come from the NC3 database specifically identified for QSRs (Richman et al. 2008). The mix of spaces is used to determine the lighting power for the whole building, which is then applied evenly with the same LPD value. The standard also includes various 
mandatory interior lighting control requirements such as building-wide automatic shut off for buildings with floor areas greater than $5000 \mathrm{ft}^{2}\left(465 \mathrm{~m}^{2}\right)$. However, the QSR prototype falls below the floor-area criteria. Mandatory controls are not simulated explicitly because the lighting diversity schedule is assumed to have considered these controls. Figure 3.1 shows the typical weekday and weekend lighting schedule with $15 \%$ of the lights energized during unoccupied hours.

Table 3.5. Baseline Lighting Power Density

\begin{tabular}{|c|c|c|c|}
\hline \multirow[b]{2}{*}{ Space Type } & \multirow{2}{*}{$\begin{array}{l}\text { Percentage of } \\
\text { Floor Area }^{(a)}\end{array}$} & \multicolumn{2}{|c|}{ Baseline LPD } \\
\hline & & $\mathrm{W} / \mathrm{ft}^{2}$ & $\mathrm{~W} / \mathrm{m}^{2}$ \\
\hline Dining & $36 \%$ & 2.08 & 22.39 \\
\hline Food Preparation & $36 \%$ & 1.20 & 12.92 \\
\hline Office - Private & $2 \%$ & 1.20 & 12.92 \\
\hline Active storage & $12 \%$ & 0.80 & 8.61 \\
\hline Restrooms & $7 \%$ & 0.74 & 7.97 \\
\hline Lobby & $2 \%$ & 1.32 & 14.21 \\
\hline Corridor/Transition & $1 \%$ & 1.36 & 14.64 \\
\hline Other & $4 \%$ & 1.20 & 12.92 \\
\hline Weighted LPD for the whole building & & 1.44 & 15.49 \\
\hline
\end{tabular}

(a) The floor area percentage for each space type is from the NC3 database developed by PNNL (Richman et al. 2008).

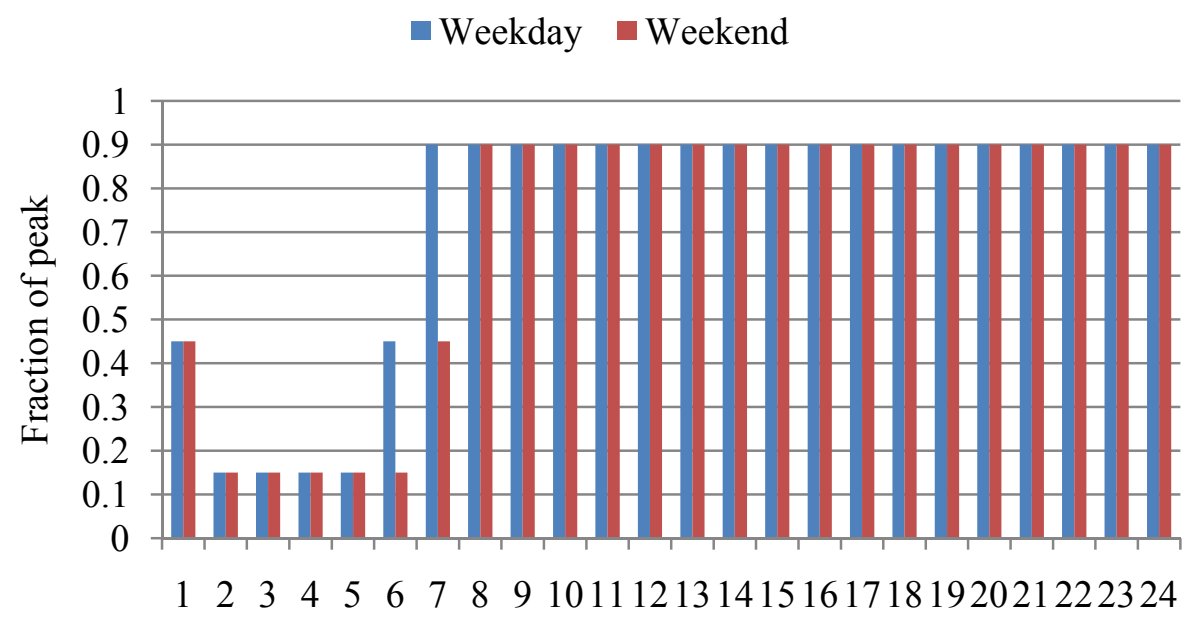

Hours

Figure 3.1. Typical Lighting Schedule for Baseline

\subsubsection{Exterior Lighting}

The building model assumes exterior lighting on the building façade, at entrances and exits, and in the parking area. Standard 90.1-2004 provides maximum lighting power allowances for each of these areas. The lighting power is based on Watts per lineal foot or Watts per square foot depending on the area type. There also is an additional allowance of $5 \%$ of the total exterior connected load to be used anywhere on 
the exterior. As shown in Table 3.6, the total connected exterior lighting load is calculated as $4333 \mathrm{~W}$ for the QSR baseline. The calculation is shown in Table 3.6 based on inputs from Standard 90.1-2004, Table 9.4.5.

Table 3.6. Baseline Exterior Lighting Power Calculation

\begin{tabular}{|c|c|c|}
\hline \multirow[b]{2}{*}{ Items } & \multicolumn{2}{|c|}{ Baseline } \\
\hline & (IP units) & (SI units) \\
\hline \multicolumn{3}{|l|}{ Parking } \\
\hline parking area, $\mathrm{ft}^{2}\left(\mathrm{~m}^{2}\right)^{(\mathrm{a})}$ & 19,553 & 1,817 \\
\hline lighting power allowance for parking $\mathrm{W} / \mathrm{ft}^{2}\left(\mathrm{~W} / \mathrm{m}^{2}\right)$ & 0.15 & 2 \\
\hline total lighting power for parking, $\mathrm{W}$ (W) & 2,933 & 2,933 \\
\hline \multicolumn{3}{|l|}{ Walkways } \\
\hline walkway area, $\mathrm{ft}^{2}\left(\mathrm{~m}^{2}\right)^{(\mathrm{a})}$ & 1108 & 103 \\
\hline lighting power allowance for walkway area $\mathrm{W} / \mathrm{ft}^{2}\left(\mathrm{~W} / \mathrm{m}^{2}\right)$ & 0.2 & 2 \\
\hline total lighting power for walkway area $\mathrm{W}(\mathrm{W})$ & 222 & 222 \\
\hline \multicolumn{3}{|l|}{ Building entrance and exits ${ }^{(a, b)}$} \\
\hline \multicolumn{3}{|l|}{ main entries } \\
\hline linear foot of door width for main entries, $\mathrm{ft}(\mathrm{m})$ & 6 & 2 \\
\hline lighting power allowance for main entries $\mathrm{W} / \mathrm{ft}(\mathrm{W} / \mathrm{m})$ & 30 & 98 \\
\hline canopy over entry, $\mathrm{ft}^{2}\left(\mathrm{~m}^{2}\right)$ & 30 & 3 \\
\hline lighting power allowance for canopy $\mathrm{W} / \mathrm{ft}^{2}\left(\mathrm{~W} / \mathrm{m}^{2}\right)$ & 1.25 & 13 \\
\hline total lighting power for main entries $\mathrm{W}(\mathrm{W})$ & 218 & 218 \\
\hline \multicolumn{3}{|l|}{ other doors } \\
\hline linear foot of door width for other doors, $\mathrm{ft}(\mathrm{m})$ & 6 & 2 \\
\hline lighting power allowance for other doors $\mathrm{W} / \mathrm{ft}(\mathrm{W} / \mathrm{m})$ & 20 & 66 \\
\hline canopy over entry $\mathrm{ft}^{2}\left(\mathrm{~m}^{2}\right)$ & 42 & 4 \\
\hline lighting power allowance for canopy $\mathrm{W} / \mathrm{ft}^{2}\left(\mathrm{~W} / \mathrm{m}^{2}\right)$ & 1.25 & 14 \\
\hline total lighting power for other doors $\mathrm{W}(\mathrm{W})$ & 173 & 173 \\
\hline total lighting power for building entrance and exits $\mathrm{W}(\mathrm{W})$ & 391 & 391 \\
\hline \multicolumn{3}{|l|}{ Building facades } \\
\hline façade area lighted $\mathrm{ft}^{2}\left(\mathrm{~m}^{2}\right)$ & 1000 & 93 \\
\hline lighting power allowance for building facades $\mathrm{W} / \mathrm{ft}^{2}\left(\mathrm{~W} / \mathrm{m}^{2}\right)$ & 0.2 & 2 \\
\hline total lighting power for building facades $\mathrm{W}(\mathrm{W})$ & 200 & 200 \\
\hline Sum of lighting power for parking, building entrance and facades $\mathrm{W}(\mathrm{W})$ & 3,746 & 3,746 \\
\hline $5 \%$ additional allowance $\mathrm{W}(\mathrm{W})$ & 187 & 187 \\
\hline \multicolumn{3}{|l|}{ Non-tradable surface allowance } \\
\hline Drive-up windows at fast food restaurants W (W) & 400 & 400 \\
\hline Total exterior lighting power $\mathrm{W}(\mathrm{W})$ & 4,333 & 4,333 \\
\hline \multicolumn{3}{|c|}{$\begin{array}{l}\text { (a) Parking and drive area, walkways, and building entrance and exits are from Standard 90.1-2004, averaged from } \\
\text { QSR site plans. } \\
\text { (b) All doors have a width of } 3 \mathrm{ft}(0.29 \mathrm{~m}) \text {. }\end{array}$} \\
\hline
\end{tabular}

Standard 90.1-2004 requires that exterior lighting have automatic controls capable of turning exterior lighting off when sufficient daylight is available or when lighting is not required. Use of astronomical 
time switches or photo sensors is required for all exterior lighting. The EnergyPlus model simulates the use of an astronomical time switch, which illuminates the exterior lights when they are scheduled on and when it is expected to be dark outside.

\subsection{Commercial Kitchen Appliances}

Food preparation processes in QSRs vary considerably depending on the type and quantity of food served. Food preparation usually consumes the most energy when compared to other energy end uses in QSRs. It is a challenging task to define a representative load density for the baseline QSR. In this study, a number of publications were reviewed. In CBECS (2003), building energy use is classified to the nine end-use types. Among the end-use types, cooking, refrigeration, and water heating are related to the food preparation process. EnergyPlus is capable of modeling the dynamic performance of service water heating, therefore, that end-use is separately discussed in Section 3.5.

\subsubsection{Estimating Cooking Energy Use}

Figure 3.2 shows the CBECS survey results for annual cooking energy use intensity (EUI) of the 36 QSRs. The values vary over a wide range. Figure 3.3 shows the results of analysis performed to determine the relationship between the EUI and restaurant versus square footage.

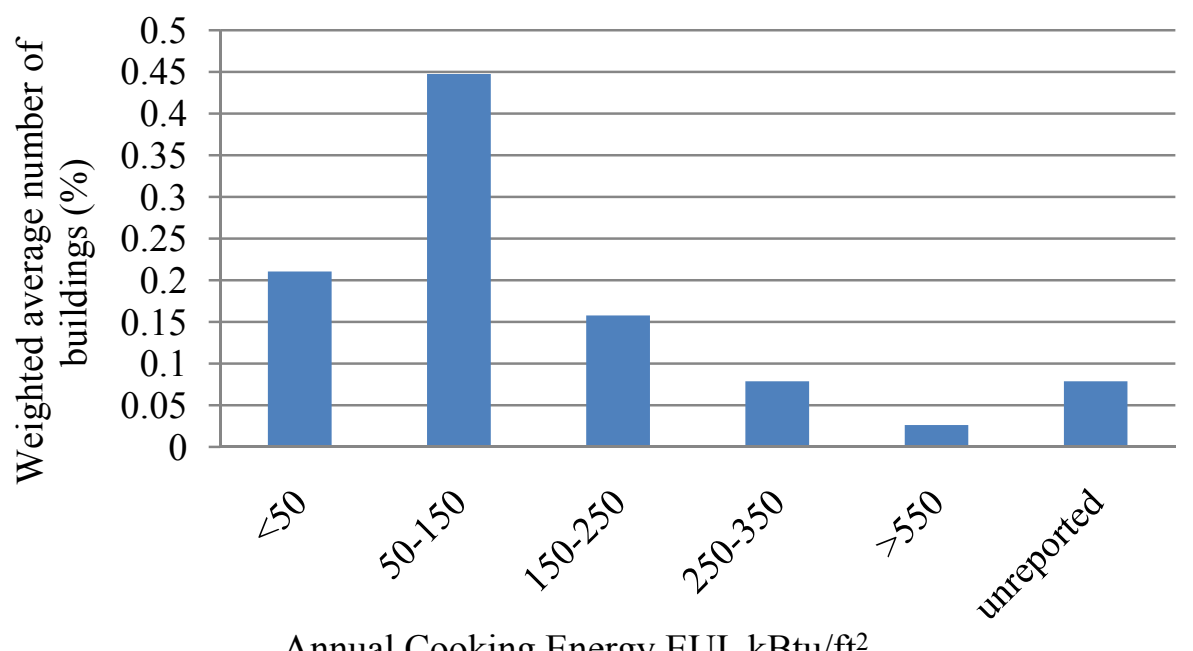

Annual Cooking Energy EUI, kBtu/ft²

Figure 3.2. Annual Cooking EUI Distribution of Post-1980 QSRs (CBECS 2003) 


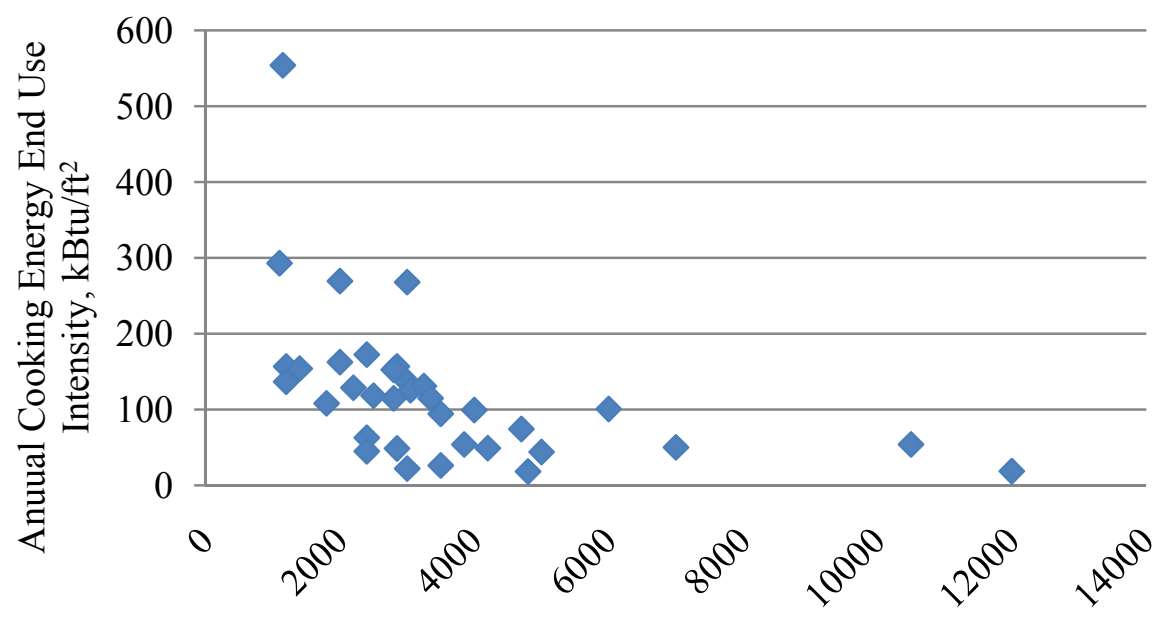

Floor Area, $\mathrm{ft}^{2}$

Figure 3.3. Relationship Between Building Floor Area and Annual Cooking Energy EUI for Post-1980 QSRs (CBECS 2003)

Although Figure 3.3 does not indicate a linear dependence between cooking energy and building size, intuitional trends can still be found: the smaller the building floor area, the larger cooking energy EUI. The second information source is the California Commercial End-Use Survey (CEUS) by California Energy Commission (CEC 2006), which reports the average annual food preparation energy EUI for California restaurants to be $213.6 \mathrm{kBtu} / \mathrm{ft}^{2}\left(673.9 \mathrm{kWh} / \mathrm{m}^{2}\right)$. The CEUS buildings include both quickservice and full-service restaurants. It should be noted that CEUS and CBECS only collected total building energy consumption data from their utility bills. The food preparation energy EUI data is estimated through data post-processing (CBECS 2003; CEC 2006). Actual metered energy end-use data in restaurants is scarce in the literature. Claar et al. (1985) selected seven facilities as the most common representative types of restaurants to conduct a one-year monitoring study. Among the facilities, the QSRs are Burger King (fast food limited menu) and Roy Rogers (fast food expanded menu). With installed sub-meters, five energy end uses (i.e., food preparation, sanitation, refrigeration, lighting, and HVAC) were measured. Akbari et al. (1993) reported the whole-building electricity end use in 4 QSRs, and they developed an End-Use Disaggregation Algorithm to estimate five types of end uses, i.e., HVAC, lighting, cooking, exhaust fan, and refrigeration. The cooking energy use data reported in those literatures is summarized in Table 3.7. 
Table 3.7. Historical Food Preparation Energy End Use from Different Sources

\begin{tabular}{|c|c|c|c|c|c|c|c|c|c|c|}
\hline Reference & \multicolumn{4}{|c|}{ Claar et al. (1985) } & \multicolumn{2}{|c|}{ Akbari et al. (1993) } & \multicolumn{2}{|c|}{$\operatorname{CBECS}^{(a)}(2003)$} & \multicolumn{2}{|c|}{ CEC (2006) } \\
\hline $\begin{array}{l}\text { Cooking Energy Data } \\
\text { source }\end{array}$ & \multicolumn{2}{|l|}{ Metering } & \multicolumn{2}{|c|}{ Metering } & \multicolumn{2}{|c|}{$\begin{array}{l}\text { Metering of } 4 \\
\text { restaurants }\end{array}$} & \multicolumn{2}{|c|}{$\begin{array}{l}\text { Post processed } \\
\text { from utility data }\end{array}$} & \multicolumn{2}{|c|}{$\begin{array}{l}\text { Post processed } \\
\text { from utility data }\end{array}$} \\
\hline Floor area $\mathrm{ft}^{2}$ & \multicolumn{2}{|l|}{3093} & \multicolumn{2}{|l|}{2758} & \multicolumn{2}{|c|}{$3650-5780$} & \multicolumn{2}{|c|}{$1100-12000$} & \multicolumn{2}{|l|}{$\mathrm{N} / \mathrm{A}$} \\
\hline Building Description & \multicolumn{2}{|c|}{$\begin{array}{l}\text { Fast food } \\
\text { limited menu }\end{array}$} & \multicolumn{2}{|c|}{$\begin{array}{l}\text { Fast food } \\
\text { expanded menu }\end{array}$} & \multicolumn{2}{|c|}{ Fast food restaurant } & \multicolumn{2}{|c|}{$\begin{array}{l}\text { Fast food } \\
\text { restaurant }\end{array}$} & \multicolumn{2}{|c|}{$\begin{array}{l}\text { Various } \\
\text { restaurants }\end{array}$} \\
\hline $\begin{array}{l}\text { Annual food } \\
\text { preparation EUI } \\
\mathrm{kBtu} / \mathrm{ft}^{2}\end{array}$ & \multicolumn{2}{|l|}{324} & \multicolumn{2}{|l|}{216} & \multicolumn{2}{|l|}{ N/A } & \multicolumn{2}{|l|}{123} & \multicolumn{2}{|l|}{213} \\
\hline Fuel source & electric & gas & electric & gas & electric & gas & electric & gas & electric & gas \\
\hline $\mathrm{kBtu} / \mathrm{ft}^{2}$ per fuel source & 63 & 258 & 100 & 115 & 36 & N/A & 21 & 102 & 35.5 & 178 \\
\hline Percentage of source & $19.6 \%$ & $80.4 \%$ & $46.5 \%$ & $53.5 \%$ & N/A & N/A & $17.0 \%$ & $83.0 \%$ & $16.6 \%$ & $83.4 \%$ \\
\hline
\end{tabular}

(a) Buildings with zero cooking EUI are excluded from the CBECS 2003 results.

However, the EUI data also needs to be evaluated from a historical perspective. There are three key factors that have been driving the EUIs significantly higher in recent years: the first factor is the heavy emphasis on drive-through windows and the fact that most QSRs have been working on increasing their service speed (e.g., serving more vehicles in the same amount of time); the second factor is the expansion of menu items and associated cooking appliances. Consider how many QSRs now serve products such as high-end coffee, which were not available a few years ago. The third factor is that as construction costs have increased, the square footage allocated to both the kitchen and dining areas have decreased even while the quantity of foodservice equipment has increased in the restaurants (Scarpa 2010).

More recent data for the annual energy use (total building and break down by end-use category) for three different QSRs are shown in Table 3.8 and their locations are also indicated. It is important to note that these restaurants rank at the top in regards to energy efficiency for this building sector. The square footage of these three facilities ranges from 2000 to $2500 \mathrm{ft}^{2}\left(186\right.$ to $\left.232 \mathrm{~m}^{2}\right)$ and are consistent with the size of the baseline model building in this study. It can be observed from Table 3.8 that for highly efficient QSRs the EUI for the total building can be as high as $1,154 \mathrm{kBtu} / \mathrm{ft}^{2}\left(3,640 \mathrm{kWh} / \mathrm{m}^{2}\right)$ with an average of $969 \mathrm{kBtu} / \mathrm{ft}^{2}\left(3057 \mathrm{kWh} / \mathrm{m}^{2}\right)$. The other key piece of information that can be obtained from the data in Table 3.8 is that the percentage of energy that can be attributed to the food preparation process, including both food preparation and refrigeration, is as high as 47\% in QSR 3. The breakdown for QSR 2 and QSR3 were estimated from on-site data collection but the annual EUI's are based on actual billing history data. From these restaurants, the annual EUI value for cooking is approximately $407 \mathrm{kBtu} / \mathrm{ft}^{2}$ $\left(1,284 \mathrm{kWh} / \mathrm{m}^{2}\right)$. 
Table 3.8. EUI Data for QSRs with a Building Area of 2000 to $2500 \mathrm{ft}^{2}$ (186 to $232 \mathrm{~m}^{2}$ )

\begin{tabular}{lccc}
\hline & \multicolumn{3}{c}{ Annual EUIs $\left(\mathrm{kBtu} / \mathrm{ft}^{2}\right)$} \\
\cline { 2 - 4 } \multicolumn{1}{c}{ End-Use } & $\begin{array}{c}\text { QSR 1 } \\
\text { (Tennessee, U.S.) }\end{array}$ & $\begin{array}{c}\text { QSR 2 } \\
\text { (Alberta, Canada) }\end{array}$ & $\begin{array}{c}\text { QSR 3 } \\
(\text { British Columbia, Canada) }\end{array}$ \\
\hline Lighting & -- & 139.9 & 139.9 \\
Food Preparation & -- & 407.4 & 407.4 \\
HVAC & -- & 536.8 & 298.0 \\
Refrigeration & -- & 23.9 & 23.9 \\
Water Heating & -- & 46.8 & 46.9 \\
TOTAL & 837.0 & 1154.8 & 916.1 \\
\hline
\end{tabular}

Proprietary data collected by authors over 650 QSRs was evaluated with regard to the facility square footage, and the results are presented in Table 3.9 as well as graphically in Figure 3.4. As can be seen from the data, the total building EUI varies greatly with the floor area of the building. It is expected that the cooking EUIs also will vary with the floor area because most QSRs have a standardized cooking platform that does not significantly vary from store to store even when the overall building floor area varies.

Table 3.9. Variation in Total Building EUI with Building Square Footage for QSRs

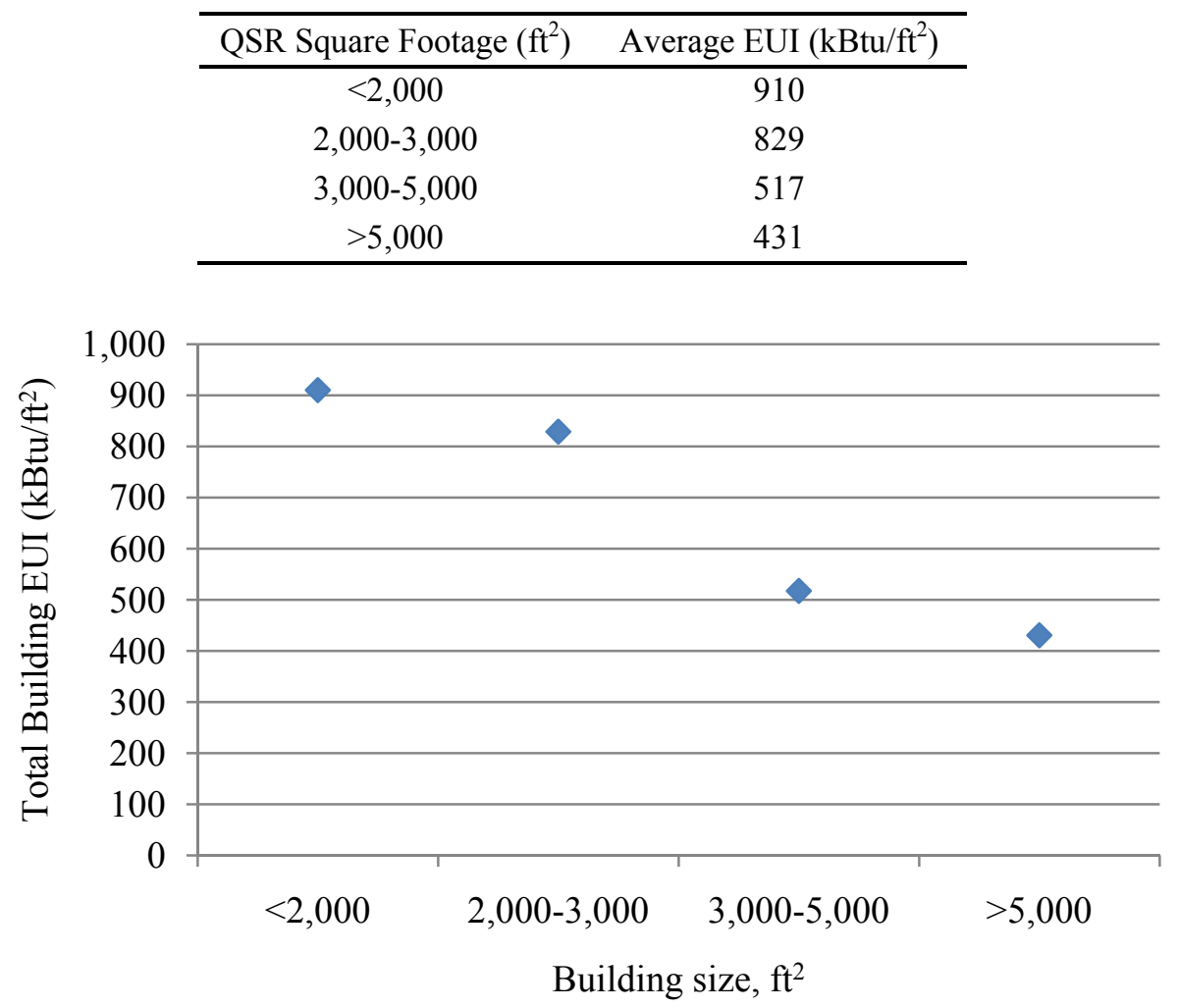

Figure 3.4. Total Building EUI Variation with Square Footage for QSRs

In conclusion, the total building EUI for a high-volume, "hamburger-based" QSR with typical food preparation equipment and ventilation systems can exceed $1,000 \mathrm{kBtu} / \mathrm{ft}^{2}\left(3,155 \mathrm{kWh} / \mathrm{m}^{2}\right)$, with a cooking 
EUI in the range of 400 to $450 \mathrm{kBtu} / \mathrm{ft}^{2}\left(1262\right.$ to $\left.1419 \mathrm{kWh} / \mathrm{m}^{2}\right)$ being a reasonable representation for the energy use by food preparation equipment. The cooking EUI data from Claar (1985), Akbari (1993), CBECS (2003), and CEC (2006) may not represent the square footage of typical QSR restaurants, or they may not represent the variety of cooking equipment commonly utilized today. Another issue with the CBECS data is that it contains a mixture of older and newer construction, which also adds to inconsistencies when trying to benchmark a cooking EUI value for QSRs that reflects current practices.

\subsubsection{Cooking Appliances}

The analysis discussed in Section 3.3.1 is used to refine the duty level of the equipment in the restaurant as described later in this section; however, it is still necessary to define the actual cooking appliances that will be used in the QSR baseline model. EPRI (1995) published a Foodservice Equipment Applications Handbook that identifies six most-common types of major cooking appliances with the likelihood of their applications in various foodservice establishments as shown in Table 3.10. To get more insight on typical QSR cooking appliances, a review of the QSR drawings from the Dodge Database was conducted and the results are summarized in Table 3.11. Other information resources on the energy use of different cooking appliances were also reviewed - for example, a research paper by Smith and Fisher (2001), the ENERGY STAR website, ${ }^{1}$ and the Food Service Technology Center website. ${ }^{2}$

Table 3.10. Major Cooking Equipment Found in Foodservice Establishments Center (EPRI 1995)

\begin{tabular}{|c|c|c|c|c|c|c|}
\hline & Griddles & Fryers & Broilers & Ovens & Ranges & Kettles \\
\hline \multicolumn{7}{|l|}{ Restaurants } \\
\hline Fast Food & $\mathbf{0}$ & 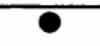 & $\square$ & $\square$ & $\square$ & $\mathrm{O}$ \\
\hline \multicolumn{7}{|l|}{ Full Menu } \\
\hline Pizza & $\mathrm{O}$ & $\mathrm{O}$ & $\mathrm{O}$ & C & $\mathrm{O}$ & $\mathrm{O}$ \\
\hline Cafeteria & D & & $\mathbf{O}$ & & & \\
\hline \multicolumn{7}{|l|}{ Hotels } \\
\hline \multicolumn{7}{|l|}{ Schools } \\
\hline \multicolumn{7}{|l|}{ Colleges } \\
\hline \multicolumn{7}{|l|}{ Hospitals } \\
\hline \multicolumn{7}{|l|}{ Nursing Homes } \\
\hline \multicolumn{7}{|l|}{ Corporate Cafeterias } \\
\hline Grocery Stores & $\bar{a}$ & $\square$ & $\mathrm{O}$ & O & $\mathrm{O}$ & $\mathrm{O}$ \\
\hline Convenience Stores & $\square$ & $\bar{\square}$ & $\mathrm{O}$ & $\square$ & $\mathrm{O}$ & $\mathrm{O}$ \\
\hline Delicatessens & $\mathrm{O}$ & $\mathrm{O}$ & $\mathrm{O}$ & D & 口 & $\mathrm{O}$ \\
\hline Drinking Places & (9 & 8 & $\overline{0}$ & O & $\mathrm{O}$ & $\mathrm{O}$ \\
\hline $\begin{array}{l}\text { Very likely } \\
\text { Somewhat likely } \\
\text { Not likely }\end{array}$ & 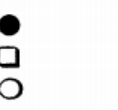 & & & & & \\
\hline
\end{tabular}

\footnotetext{
${ }^{1}$ ENERGY STAR is a joint program of the U.S. Environmental Protection Agency and DOE. It provides information on various cooking equipment products and practices. Information retrieved September 2010 from http://www.energystar.gov/index.cfm?c=bulk_purchasing.bus purchasing\#food.

${ }^{2}$ Food Service Technology Center is funded by Pacific Gas and Electric. It provides information on commercial kitchen energy efficiency and appliance performance testing. Information retrieved September 2010 from http://www.fishnick.com/equipment/techassessment/.
} 
While Table 3.10 and Table 3.11 both contain valuable information on the equipment being used by various QSRs, a philosophical decision needed to be made on how to define the cooking-equipment mix in the baseline QSR. Specifically, should the baseline restaurant have a mix of appliances (as shown in the tables) or should a typical restaurant with an actual cooking process be represented? Table 3.10 shows a general overview of what is being used by QSRs, with griddles and fryers being highly likely followed by broilers, ovens, and ranges being somewhat likely in the fast food restaurant segment.

Table 3.11 shows what equipment types are used across a variety of QSRs. Because QSRs tend to take a focused approach when designing their cooking process, we decided to define the baseline and advanced restaurant as a "hamburger" style of restaurant. For this style of restaurant, the cooking equipment selected for use under ventilation hoods were griddles and deep-fat fryers, which also are shown to be the most likely types of appliances for "Fast Food" restaurants listed in Table 3.10.

Table 3.11. Summary of QSR Equipment from the Dodge Database

\begin{tabular}{|c|c|c|c|c|c|c|c|c|c|c|c|}
\hline & $\begin{array}{c}\text { Fuel } \\
\text { source }\end{array}$ & $\begin{array}{c}\text { Brand } \\
1 \mathrm{~A}\end{array}$ & $\begin{array}{c}\text { Brand } \\
1 \mathrm{~B}\end{array}$ & $\begin{array}{c}\text { Brand } \\
2\end{array}$ & $\begin{array}{c}\text { Brand } \\
3\end{array}$ & $\begin{array}{c}\text { Brand } \\
4\end{array}$ & $\begin{array}{c}\text { Brand } \\
5 \mathrm{~A}\end{array}$ & $\begin{array}{c}\text { Brand } \\
5 \mathrm{~B}\end{array}$ & $\begin{array}{c}\text { Brand } \\
6\end{array}$ & $\begin{array}{c}\text { Brand } \\
7\end{array}$ & $\begin{array}{c}\text { Brand } \\
8\end{array}$ \\
\hline \multirow[t]{2}{*}{ Griddle } & Elec & 2 & 2 & 1 & 0 & 1 & 0 & 0 & 0 & 1 & 0 \\
\hline & Gas & 0 & 0 & 0 & 1 & 0 & 0 & 0 & 0 & 1 & 0 \\
\hline \multirow[t]{2}{*}{ Fryer } & Elec & 0 & 0 & 1 & 0 & 2 & 0 & 0 & 0 & 3 & 0 \\
\hline & Gas & 2 & 2 & 0 & 0 & 0 & 1 & 1 & 1 & 0 & 1 \\
\hline Broiler & Gas & 0 & 0 & 1 & 0 & 0 & 1 & 1 & 0 & 0 & 0 \\
\hline \multirow[t]{2}{*}{ Oven } & Elec & 1 & 0 & 1 & 0 & 0 & 3 & 3 & 2 & 4 & 0 \\
\hline & Gas & 0 & 1 & 0 & 0 & 0 & 0 & 0 & 2 & 0 & 0 \\
\hline \multirow[t]{2}{*}{ Range } & Elec & 0 & 0 & 0 & 0 & 1 & 0 & 0 & 0 & 0 & 0 \\
\hline & gas & 0 & 0 & 0 & 0 & 0 & 0 & 0 & 0 & 0 & 0 \\
\hline \multirow[t]{2}{*}{ Steam cooker } & Elec & 1 & 0 & 0 & 0 & 0 & 0 & 0 & 0 & 0 & 0 \\
\hline & Gas & 0 & 0 & 1 & 2 & 0 & 0 & 0 & 0 & 0 & 0 \\
\hline Hot food holding cabinets & Elec & 0 & 0 & 0 & 0 & 0 & 0 & 3 & 1 & 0 & 2 \\
\hline Dish machines & Elec & 1 & 1 & 0 & 0 & 0 & 0 & 0 & 0 & 0 & 0 \\
\hline Toaster & Elec & 0 & 0 & 0 & 1 & 1 & 2 & 2 & 2 & 1 & 2 \\
\hline Cooled beverage machine & Elec & 6 & 5 & 1 & 5 & 2 & 4 & 1 & 0 & 3 & 3 \\
\hline Coffee brewer & Elec & 5 & 5 & 1 & 1 & 2 & 0 & 2 & 2 & 3 & 0 \\
\hline Blender & Elec & 1 & 2 & 1 & 1 & 0 & 0 & 0 & 0 & 0 & 0 \\
\hline Dispensers & Elec & 4 & 1 & 3 & 1 & 1 & 0 & 3 & 3 & 0 & 0 \\
\hline $\begin{array}{l}\text { Reach-in refrigerator/ } \\
\text { freezer }\end{array}$ & Elec & 7 & 4 & 5 & 2 & 3 & 3 & 3 & 1 & 4 & 1 \\
\hline Ice machine & Elec & 4 & 1 & 1 & 2 & 1 & 0 & 0 & 3 & 2 & 2 \\
\hline Washer/dryer & Elec & 1 & 1 & 0 & 0 & 0 & 0 & 0 & 0 & 0 & 0 \\
\hline
\end{tabular}

With regard to the specific cooking appliances for the baseline restaurant, our selection was based on typical equipment that is currently used in the industry. Two gas-fired griddles were selected and modeled as being 36-in. (914-mm) wide, each with a nameplate input of 90,000 Btu/h (26,377 W). The performance data for the griddles are summarized in Table 3.12, based on a publically available report for the U.S. range model RGTSA griddle (FSTC 2003; FSTC 2010a). The deep-fat fryers selected for the baseline restaurant have been a workhorse of the restaurant industry for several years and are still used often by QSRs. For the baseline QSR, four gas-fired, 15-in. (381-mm) wide fryers were selected (FSTC 2010a). The corresponding performance data are shown in Table 3.13. The data are based on proprietary testing performed for these fryers. 
Table 3.12. Baseline Griddle Performance Data

\begin{tabular}{lcc}
\hline Appliance State & Energy Input (\% of Nameplate) & Production Capacity, $\mathrm{lb} / \mathrm{h}(\mathrm{kg} / \mathrm{h})$ \\
\hline Idle & $24 \%$ & $0.0(0.0)$ \\
Light & $34 \%$ & $6.9(3.1)$ \\
Medium & $46 \%$ & $16.2(7.3)$ \\
Heavy & $65 \%$ & $33.0(15.0)$ \\
\hline
\end{tabular}

Table 3.13. Baseline Fryer Performance Data

\begin{tabular}{lcc}
\hline Appliance State & Energy Input (\% of Nameplate) & Production Capacity, $\mathrm{lb} / \mathrm{h},(\mathrm{kg} / \mathrm{h})$ \\
\hline Idle & $11 \%$ & $0.0(0.0)$ \\
Light & $39 \%$ & $19.6(8.9)$ \\
Medium & $58 \%$ & $36.7(16.6)$ \\
Heavy & $94 \%$ & $69.2(31.4)$ \\
\hline
\end{tabular}

Additionally for modeling purposes it was necessary to define the appliance state for each of the griddles and fryers as a function of the building occupancy (from Figure 2.8). The operational state (e.g., idle, light-load, medium-load, etc.) was defined for each appliance as a function of the number of customers being served (whether that was in-store or drive-through customers) with the general trend being that more appliances were used to cook food when more customers were being served. The appliance operational state matrix is shown in Table 3.14.

Table 3.14. Baseline Model Appliance Usage Matrix with Percent Occupancy

\begin{tabular}{ccccccccc}
\hline & \multicolumn{4}{c}{ Griddle Duty/Quantity } & \multicolumn{4}{c}{ Fryer Duty/Quantity } \\
\cline { 2 - 8 } \% Occupancy & Idle & Light & Medium & Heavy & Idle & Light & Medium & Heavy \\
\hline $0-29 \%$ & 2 & 0 & 0 & 0 & 4 & 0 & 0 & 0 \\
$30-39 \%$ & 1 & 1 & 0 & 0 & 3 & 1 & 0 & 0 \\
$40-59 \%$ & 1 & 0.4 & 0.6 & 0 & 2 & 2 & 0 & 0 \\
$60-100 \%$ & 0 & 1.2 & 0.8 & 0 & 0.9 & 2.6 & 0.5 & 0 \\
\hline
\end{tabular}

Applying the usage matrix from Table 3.14 with the griddles and fryers for the baseline restaurant, a calculated annual cooking appliance EUI of $423 \mathrm{kBtu} / \mathrm{ft}^{2}\left(1,334 \mathrm{kWh} / \mathrm{m}^{2}\right)$ is obtained, which agrees with the recommendations from Section 3.3.1 on cooking EUIs.

The equipment located under the ventilation hoods is summarized in Table 3.15. The two gas griddles are beneath one hood and the four fryers and dump station are beneath a second hood. For equipment that is hooded, only sensible heat gain from appliance radiation should contribute to the heating loads in the kitchen space. The sensible radiation load to the space is calculated as the product of the nameplate input multiplied times the usage factor $\left(F_{u}\right)$ and the sensible radiant factor $\left(F_{r}\right)$ as shown in the equation below. The radiation factors were taken from the results of the ASHRAE research project RP-1362 (Fisher et al. 2008).

$$
\text { Sensible Heat Gain }=\text { Nameplate Input } \times \mathrm{F}_{\mathrm{u}} \times \mathrm{F}_{\mathrm{r}}
$$


Table 3.15. Baseline Hooded Equipment

\begin{tabular}{cccccc}
\hline & & & & & \\
Quantity & Type & Fuel Source & Width (in.) & Nameplate Input (kBtu/h) & (ASHRAE RP-1362) \\
\hline 2 & Griddle & Gas & 36 & 90 & 0.44 \\
4 & Fryers & Gas & 15 & 122 & 0.28 \\
1 & Dump Station & -- & 15 & -- & -- \\
Total & & & & 668 & \\
\hline
\end{tabular}

The unhooded equipment was sorted into the following three categories:

1. Equipment that operates while the restaurant is open

2. Equipment used only during the breakfast hours of 6:00 a.m. to 10:30 a.m.

3. Refrigeration equipment that is operated 24 hours per day.

The third category (refrigeration equipment) is discussed in Section 3.3.3. The equipment used during the open restaurant hours are shown in Table 3.16, which includes the quantity of each equipment type, the usage factor during idle and cooking times, and the thermal load added to the space due to radiation. Table 3.17 shows similar data for the convection oven, which is modeled as being used for breakfast only.

For the unhooded equipment, the sensible load to the space is calculated as the product of multiplying the nameplate input times the usage factor $\left(\mathrm{F}_{\mathrm{u}}\right)$ and times sum of the sensible radiant factor $\left(\mathrm{F}_{\mathrm{r}}\right)$ and sensible convective factor $\left(\mathrm{F}_{\mathrm{s}}\right)$ as shown in the following equation:

$$
\text { Sensible Heat Gain }=\text { Nameplate Input } \times F_{u} \times\left(F_{r}+F_{s}\right)
$$

In addition, for the unhooded equipment, there may be a latent heat load to the space (such as was assumed with the coffee brewers, coffee warmers, and food holding cabinets), which is calculated as the product of the nameplate input, usage factor $\left(\mathrm{F}_{\mathrm{u}}\right)$ and latent load factor $\left(\mathrm{F}_{\mathrm{L}}\right)$ as shown in the following equation:

$$
\text { Latent Heat Gain }=\text { Nameplate Input } \times \mathrm{F}_{\mathrm{u}} \times \mathrm{F}_{\mathrm{L}}
$$

The usage $\left(\mathrm{F}_{\mathrm{u}}\right)$, sensible radiant $\left(\mathrm{F}_{\mathrm{r}}\right)$, sensible convective $\left(\mathrm{F}_{\mathrm{s}}\right)$, and latent load $\left(\mathrm{F}_{\mathrm{L}}\right)$ factors were taken either from the published results in Chapter 18 (Nonresidential Cooling and Heating Load Calculations) of the ASHRAE Fundamentals (ASHRAE 2009) or directly from the results of the ASHRAE RP-1362 research project (Fisher et al. 2008). 
Table 3.16. Baseline Model Equipment Operating During Open Restaurant Hours

\begin{tabular}{clccccccc}
\hline \multirow{2}{*}{ Quantity } & \multicolumn{1}{c}{ Type } & $\begin{array}{c}\text { Nameplate Input, } \\
\text { each }(\mathrm{kW})\end{array}$ & $\mathrm{F}_{\mathrm{u}, \mathrm{idle}}$ & $\mathrm{F}_{\mathrm{u}, \mathrm{cook}}$ & $\mathrm{F}_{\mathrm{r}}$ & $\mathrm{F}_{\mathrm{s}}$ & $\mathrm{F}_{\mathrm{L}}$ & Sources \\
\hline 1 & Coffee brewer & 3.9 & 0.09 & -- & 0.17 & 0.25 & 0.58 & (a) \\
1 & Juice dispenser & 0.6 & 0.4 & -- & 0.25 & 0.75 & 0 & (a) \\
1 & Milk-shake dispenser & 3.9 & 0.15 & -- & 0.25 & 0.75 & 0 & (a) \\
1 & Ice-cream dispenser & 3.9 & 0.15 & -- & 0.25 & 0.75 & 0 & (a) \\
1 & Heat lamp & 2.9 & 1 & -- & 0.5 & 0.5 & 0 & (a) \\
3 & Holding cabinets & 2.5 & 0.35 & -- & 0.27 & 0.54 & 0.18 & (b) \\
2 & Microwaves & 6.8 & & 0.25 & 0.25 & 0.75 & 0 & (b) \\
2 & Conveyor toasters & 3.8 & 0.47 & -- & 0.11 & 0.89 & 0 & (a) \\
1 & Coffee warmer & 1 & 0.09 & -- & 0.17 & 0.25 & 0.58 & (a) \\
\hline
\end{tabular}

(a) Smith and Fisher (2001)

(b) Data from proprietary QSR study

Table 3.17. Baseline Equipment Operating During Breakfast Hours

\begin{tabular}{ccccccccc}
\hline \multirow{2}{*}{ Quantity } & Type & $\begin{array}{c}\text { Name Plate Input, } \\
\text { each }(\mathrm{kW})\end{array}$ & $\mathrm{F}_{\mathrm{u} \text {,idle }}$ & $\mathrm{F}_{\mathrm{u}, \mathrm{cook}}$ & $\mathrm{F}_{\mathrm{r}}$ & $\mathrm{F}_{\mathrm{s}}$ & $\mathrm{F}_{\mathrm{L}}$ & Sources \\
\hline 2 & Half-size convection ovens & 5.5 & 0.2 & -- & 0.17 & 0.83 & 0 & $(\mathrm{a})$ \\
\hline
\end{tabular}

(a) Data from proprietary QSR study

For the equipment beneath the ventilation hoods, the average hourly energy use at any time of the day was calculated as the sum, for all the appliances (a total count of $n$ ), of the product of the nameplate input times the usage factor $\left(\mathrm{F}_{\mathrm{u}}\right)$ as shown in the following equation:

$$
\text { Energy Use }=\sum_{i=0}^{n} \text { Nameplate Input } \times \mathrm{F}_{\mathrm{u}}
$$

The usage factors were based on the appliance operating schedule from Table 3.14, which is based on the occupancy of the restaurant during any given hour. The fractional usage profiles for the hooded and unhooded appliances are shown in Figure 3.5 through Figure 3.8. 


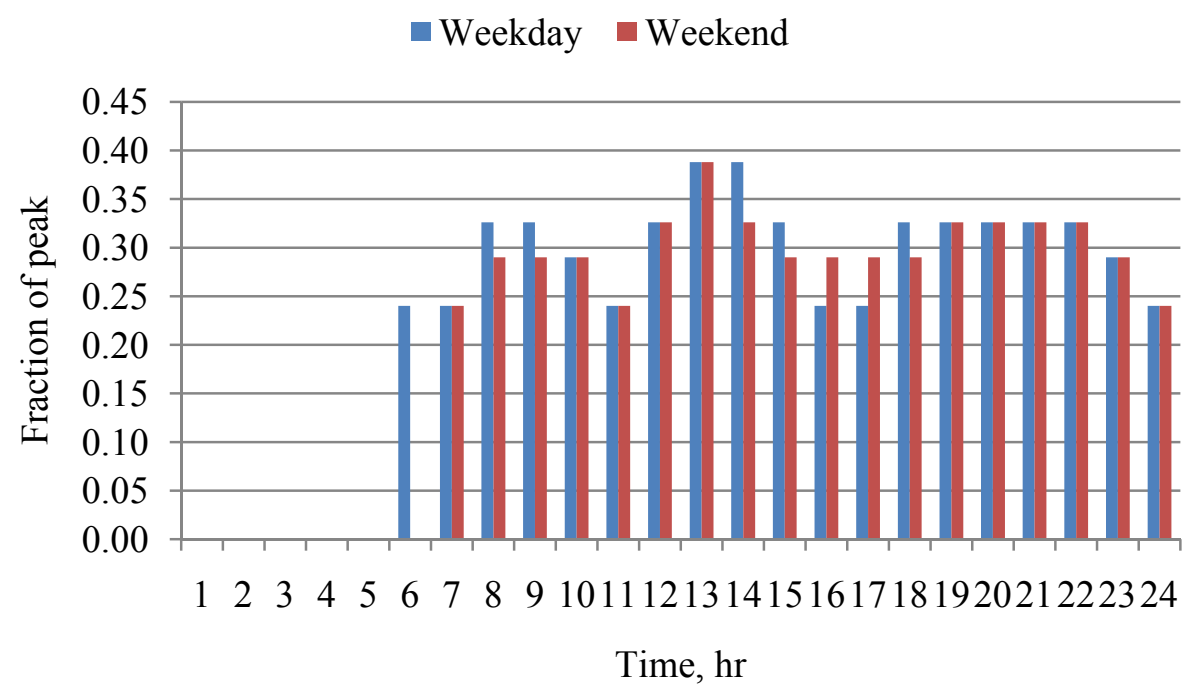

Figure 3.5. Baseline Fractional Usage Profile for the Hooded Cooking Griddle

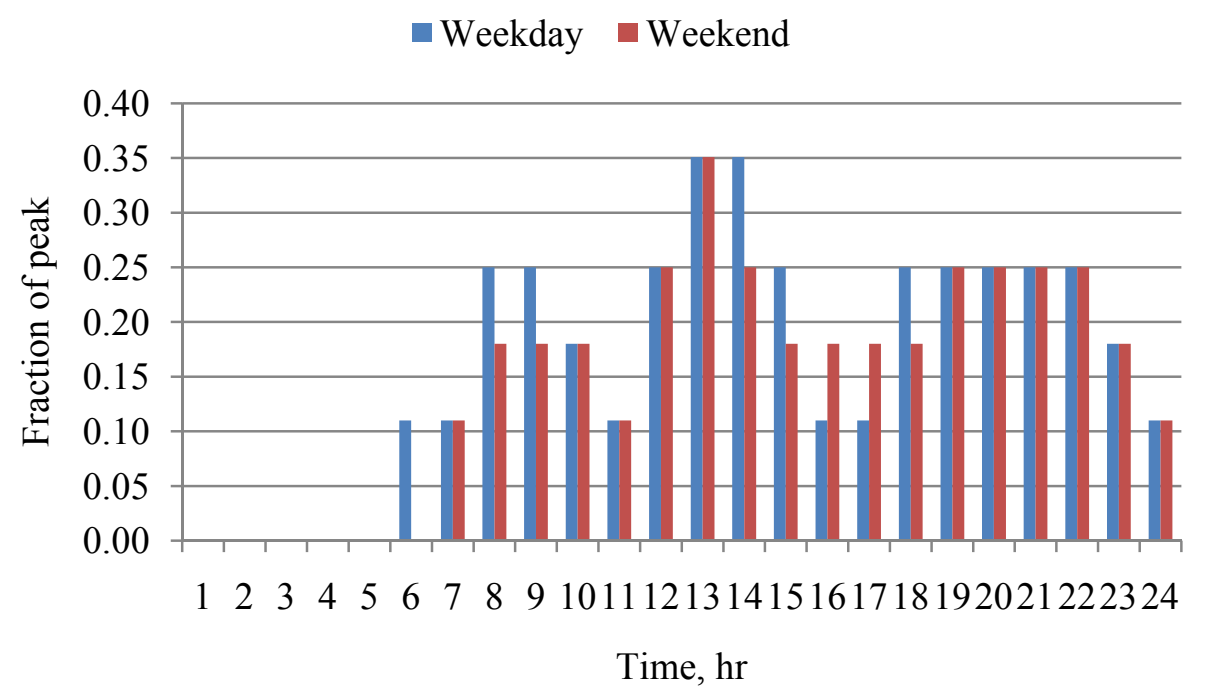

Figure 3.6. Baseline Fractional Usage Profile for the Hooded Cooking Fryer 


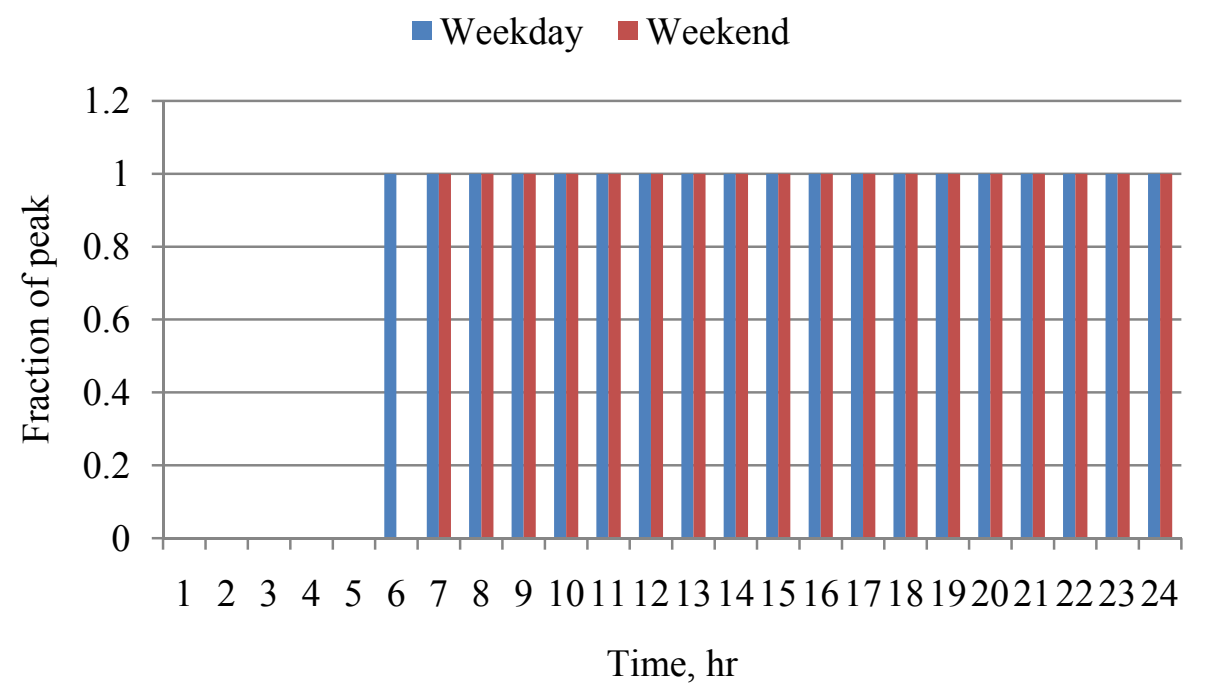

Figure 3.7. Baseline Fractional Usage Profile for the Unhooded Cooking Equipment that Operates While the Restaurant is Open

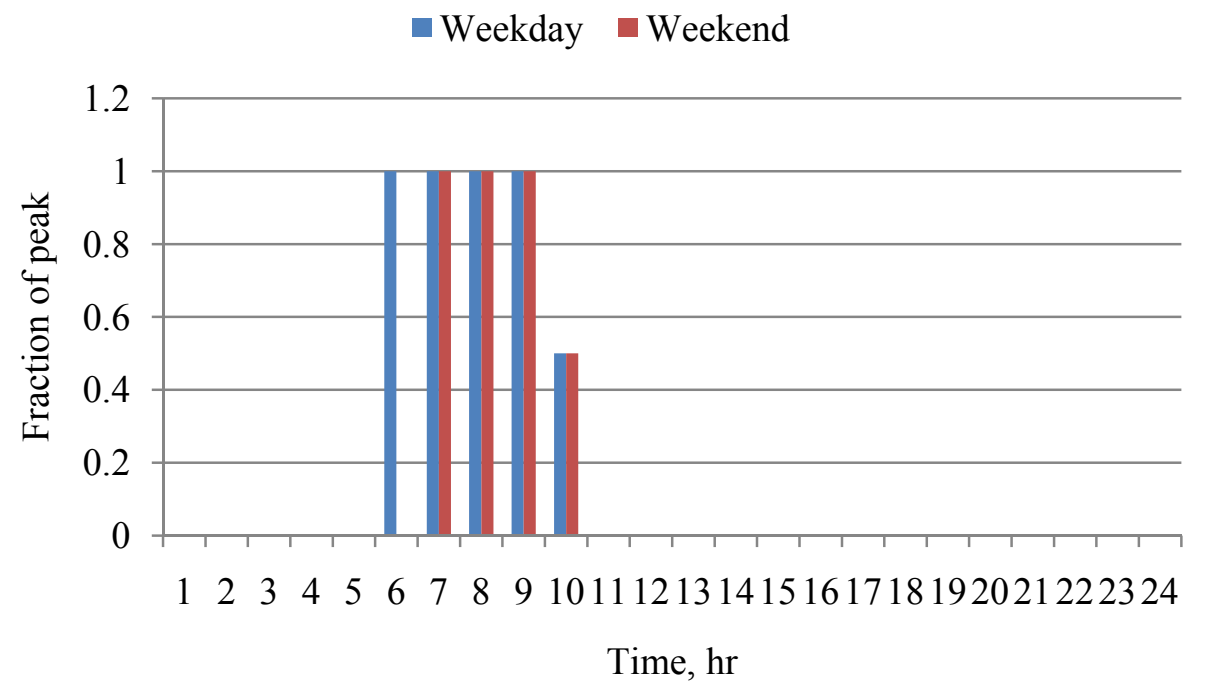

Figure 3.8. Baseline Fractional Usage Profile for the Unhooded Cooking Equipment only Used During Breakfast Hours

\subsubsection{Refrigeration Equipment}

Refrigeration equipment such as reach-in and walk-in freezers and coolers are commonly used in QSRs as confirmed by the drawing review results shown in Table 3.11 and Table 3.18. Therefore, they also are included in the prototype EnergyPlus building model. Although EnergyPlus has a refrigeration system simulation function, it has not been well tested. In addition, the program requires several inputs that are very challenging to define. The authors have decided to model the refrigeration systems as a plug load, and they are assumed to operate constantly 24 hours per day. Table 3.19 shows the corresponding information for the refrigeration equipment. The baseline walk-in refrigeration systems are assumed to be 
industry standard designs: 3.5 -in. $(88-\mathrm{mm})$ thick urethane insulation for the wall and ceiling panels, shaded-pole motors powering the evaporator fans, incandescent lighting, no additional infiltration barriers on the outer doors, and a standard refrigeration system with a fixed expansion valve and a manually-set defrost schedule. Other assumptions for the walk-in systems are shown in Table 3.20.

Table 3.18. Summary of Reviewed QSR Walk-In Cooler/Freezer from the Dodge Database

\begin{tabular}{ccccccccccc}
\hline & Fuel & Brand & Brand & Brand & Brand & Brand & Brand & Brand & Brand & Brand \\
Type & source & $1 \mathrm{~A}$ & 1B & 2 & 3 & 4 & 5A & 5B & 6 & 7 \\
\hline Walk-in cooler/freezer & Elec & 1 & 1 & 0 & 1 & 0 & 1 & 0 & 2 & 3 \\
\hline
\end{tabular}

Table 3.19. Baseline Refrigeration Equipment Operating 24 Hours per Day

\begin{tabular}{clcccccc}
\hline Quantity & \multicolumn{1}{c}{$\begin{array}{c}\text { Name plate } \\
\text { Input, each } \\
(\mathrm{kW})\end{array}$} & $\mathrm{F}_{\mathrm{u}}$ & $\mathrm{F}_{\mathrm{r}}$ & $\mathrm{F}_{\mathrm{s}}$ & $\mathrm{F}_{\mathrm{L}}$ & Sources \\
\hline 1 & Reach-In Refrigerator (2-door) & 1.1 & 0.25 & 0.25 & 0.75 & 0 & (b) \\
1 & Reach-in Freezer (1-door) & 1.2 & 0.41 & 0.25 & 0.75 & 0 & (b) \\
2 & Undercounter Refrigerator & 0.5 & 0.25 & 0.25 & 0.75 & 0 & (b) \\
1 & Undercounter Freezer & 0.8 & 0.41 & 0.25 & 0.75 & 0 & (b) \\
2 & Refrigerated Prep Table & 0.9 & 0.45 & 0.67 & 0.33 & 0 & (b) \\
2 & Ice Machine, 1000 lb/day & 3 & 0.5 & 0.25 & 0.75 & 0 & (a) \\
1 & Walk-in Cooler & 1.2 & 0.54 & 0.25 & 0.75 & 0 & (b) \\
1 & Walk-in Freezer & 3.8 & 0.39 & 0.25 & 0.75 & 0 & (b) \\
\hline
\end{tabular}

(a) Smith and Fisher, 2001.

(b) Data from proprietary QSR studies.

Table 3.20. Baseline Walk-In Refrigeration Systems

\begin{tabular}{lccccccc}
\hline & $\begin{array}{c}\text { Area, } \\
\mathrm{ft}^{2}\end{array}$ & $\begin{array}{c}\text { Length, } \\
\mathrm{ft}\end{array}$ & $\begin{array}{c}\text { Cooling } \\
\text { capacity } \\
\mathrm{kBtu} / \mathrm{h}\end{array}$ & $\begin{array}{c}\text { Case } \\
\text { Temperature, } \\
{ }^{\circ} \mathrm{F}\end{array}$ & $\begin{array}{c}\text { Condenser } \\
\text { Location }\end{array}$ & $\begin{array}{c}\text { Average Energy } \\
\text { Consumption } \\
\text { Rate, } \mathrm{W}\end{array}$ & $\begin{array}{c}\text { Daily Energy } \\
\text { Consumption, } \\
\mathrm{kWh}\end{array}$ \\
\hline Walk-in Cooler & 100 & 10 & 7.7 & 35 & Outdoor & 650 & 15.6 \\
Walk-in Freezer & 80 & 8 & 5.7 & -10 & Outdoor & 1,480 & 36 \\
\hline
\end{tabular}

\subsection{Baseline Building HVAC Systems}

QSRs are unique spaces with regard to the HVAC system design in that they generally have two distinct thermal zones: the dining and the kitchen zones that typically are conditioned by constant air volume (CAV) systems. The dining zone typically is driven by occupancy in the space, which dictates how much outdoor air is required. However, in the kitchen zone, the dominant use of outdoor air is to replace the air exhausted by the hood vents, thus maintaining a positive pressure in the kitchen.

Two approaches typically are used to bring replacement ventilation air into the kitchen zone of QSR buildings - Option A in which packaged rooftop units are used or Option B in which untempered air is used to supply the replacement air. Option A, the packaged rooftop solution, is shown in Figure 3.9, and Option B, the untempered scenario, is shown in Figure 3.10. With either Option A or B, the dining zone 
is served by a package roof top unit (RTU) that typically provides both cooling and heating to the dining area. Additionally, transfer air is used to provide some of the replacement air for the kitchen zone.

Option A takes the strategy of providing $100 \%$ air conditioned (heated or cooled) replacement air to the kitchen space. This has the advantage of providing uniform conditions inside the kitchen regardless of where the restaurant is located geographically in the country. By controlling the comfort in the kitchen zone, productivity and indoor air quality are improved in the kitchen. In this report, Option A is selected as the baseline. In both the baseline and low-energy advanced cases, the systems are simulated using a constant-air-volume (CAV) supply fan, a constant-speed compressor, a direct-expansion (DX) cooling coil, and a gas-fired furnace.

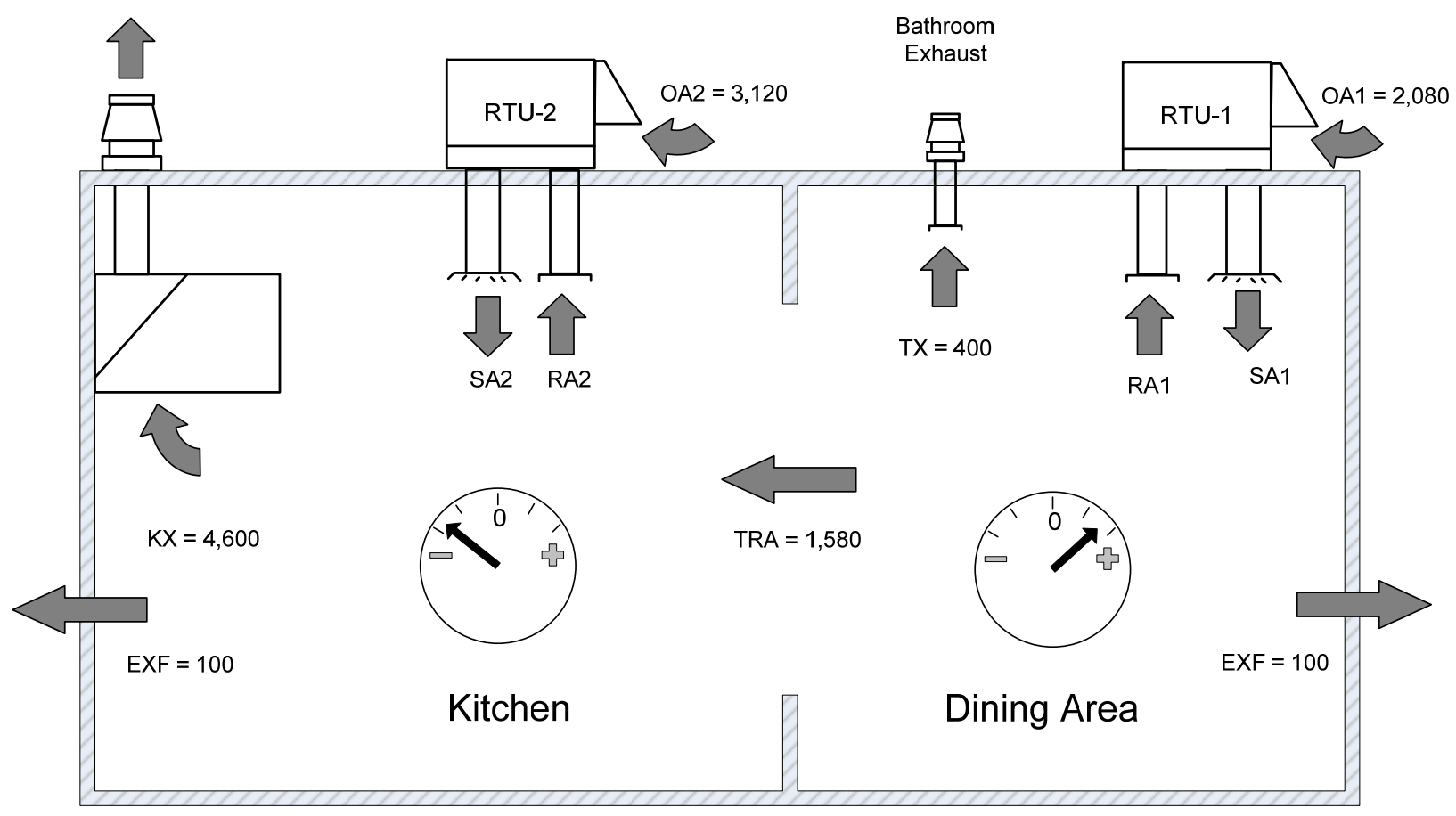

Figure 3.9. HVAC system configuration for Option A (used as the baseline in this report)

With Option B, the replacement air for the exhaust hoods is untempered, which means that the makeup air served the make-up air (MUA) unit is not cooled during the summer months and is heated to $55^{\circ} \mathrm{F}$ to $70^{\circ} \mathrm{F}\left(13\right.$ to $\left.21^{\circ} \mathrm{C}\right)$ during the winter months. This option works in some mild climates in the United States. However, for many regions of the country, this scenario may result in poor indoor air quality with regard to temperature and humidity in the space. Other factors that should be considered if selecting such a system are the potential for mold growth and condensation on surfaces in the kitchen, which can lead to potential for slips and falls. Also, from an operating cost perspective, if the latent and/or sensible loads are high, this could cause the compressor of the roof-top unit in the kitchen to run for longer periods of time. Because of the limited applicability of Option B and its potential problems, the authors decided not to use it as the baseline to evaluate its energy saving potential. However, because some readers might be interested in knowing the performance of Option B, EnergyPlus simulations were conducted for this option and the results are presented in 7.0Appendix A. 


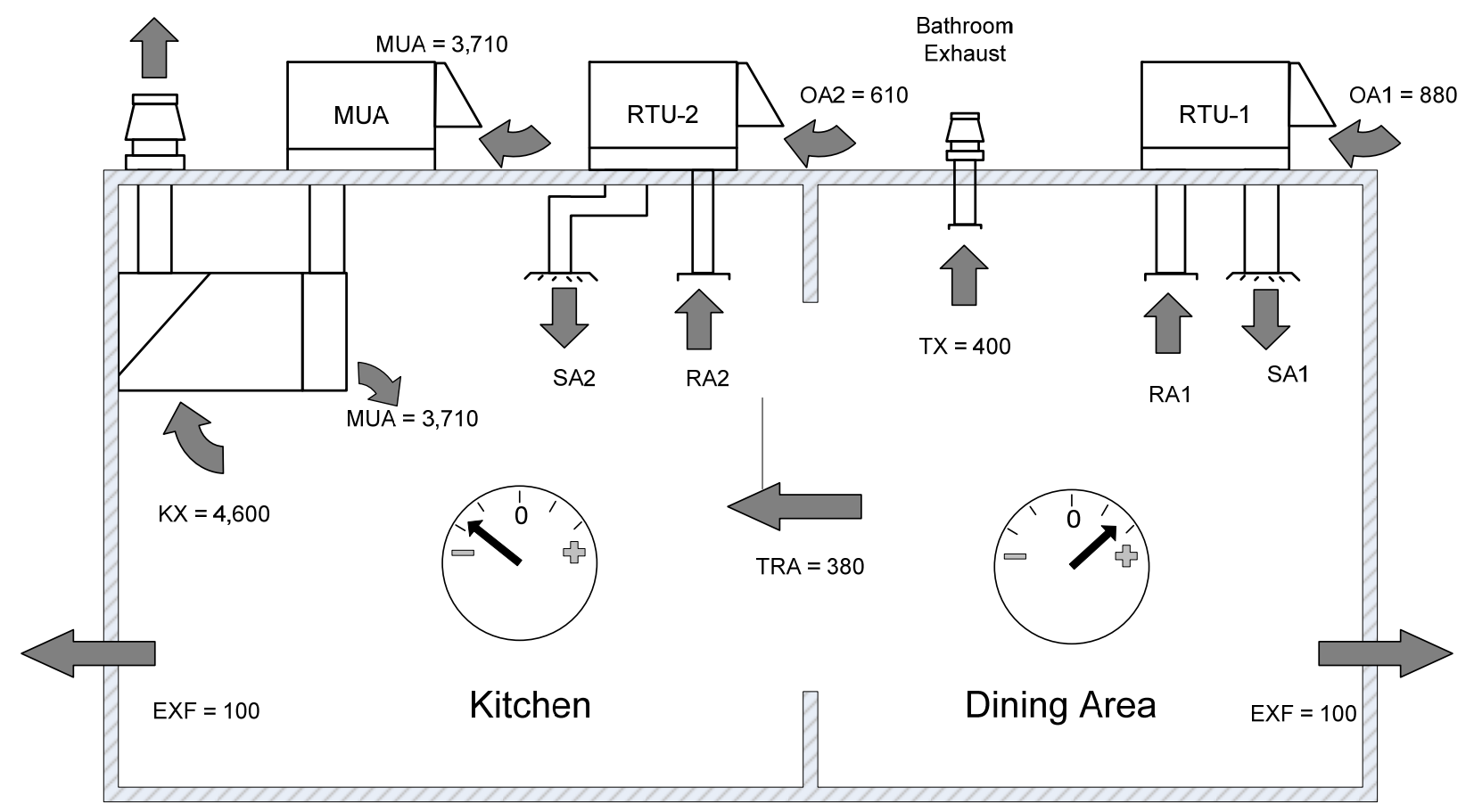

Figure 3.10. HVAC system configuration for Option B (simulation results are shown in 7.0Appendix A)

\subsubsection{Kitchen Ventilation System}

Selection of kitchen exhaust hoods for the baseline QSRs was based on the equipment selected in Section 3.3.2. The style of hoods selected were wall-mounted canopy hoods with one hood for use over the two griddles and a second hood being used over the four deep-fat fryers and a dump station where the food is stored after cooking. Table 3.21 shows the overall length, depth, height, and airflows of the hoods. The airflow per foot is based on the requirements of the International Mechanical Code (ICC 2009). The total exhaust airflow for the hoods is $4600 \mathrm{cfm}\left(2.17 \mathrm{~m}^{3} / \mathrm{s}\right)$.

Table 3.21. Baseline Kitchen Exhaust Hood Specifications

\begin{tabular}{cccccc}
\hline Hood & Style & $\begin{array}{c}\text { Length } \\
\text { in. }(\mathrm{m})\end{array}$ & $\begin{array}{c}\text { Depth } \\
\text { in. }(\mathrm{m})\end{array}$ & $\begin{array}{c}\text { Airflow } \\
\mathrm{cfm} / \mathrm{ft},\left(\mathrm{m}^{3} / \mathrm{s} / \mathrm{m}\right)\end{array}$ & $\begin{array}{c}\text { Airflow } \\
\mathrm{cfm}^{3}\left(\mathrm{~m}^{3} / \mathrm{s}\right)\end{array}$ \\
\hline Griddle & Canopy & $92(2.34)$ & $48(1.22)$ & $300(0.14)$ & $2300(1.09)$ \\
Fryer & Canopy & $92(2.34)$ & $48(1.22)$ & $300(0.14)$ & $2300(1.09)$ \\
Total & & & & & $4600(2.17)$ \\
\hline
\end{tabular}

A review on the Dodge Drawings for QSRs indicates it is a common design practice to transfer air from the dining zone to the kitchen as part of the replacement air of the exhaust hoods. The amount of transfer air is dependent on how much outdoor ventilation air is available in the dining zone.

As illustrated in Figure 3.9 and summarized in Table 3.22, the total amount of air flowing out of the baseline building is $5200 \mathrm{cfm}\left(0.45 \mathrm{~m}^{3} / \mathrm{s}\right)$ through the kitchen hoods, bathroom exhaust fans, and exfiltration. By taking advantage of the transfer air, the same amount of required replacement air can be shared reasonably by the dining and kitchen RTUs with a ratio of 2:3. In the EnergyPlus model, a ZoneMixing object is used to define the air transferred from the dining zone to the kitchen zone. 
Table 3.22. Air Balance for HVAC System - Option A (used as the baseline in this report)

\begin{tabular}{llcc}
\hline & & Airflow $(\mathrm{cfm})$ & Airflow $\left(\mathrm{m}^{3} / \mathrm{s}\right)$ \\
\hline Exhaust Air & Kitchen Exhaust Hoods & 4600 & 2.17 \\
& Bathroom & 400 & 1.89 \\
& Kitchen Exfiltration & 100 & 0.05 \\
& Dining Exfiltration & 100 & 0.05 \\
& Total & 5200 & 2.45 \\
\hline Outdoor Intake Air & Dining (RTU-1) & 2080 & 0.98 \\
& Kitchen (RTU-2) & 3120 & 1.47 \\
& Total & 5200 & 2.45 \\
\hline
\end{tabular}

ANSI/ASHRAE Standard 62.1-2004 (ANSI/ASHRAE 2004) also imposes a minimum outdoor air ventilation for acceptable indoor air quality. According to Standard 62.1, the outdoor air in the dining zone should be at least $0.18 \mathrm{cfm} / \mathrm{ft}^{2}\left(0.00091 \mathrm{~m}^{3} / \mathrm{s}-\mathrm{m}^{2}\right)$ of floor area plus $7.5 \mathrm{cfm}$ per person $\left(0.0035 \mathrm{~m}^{3} / \mathrm{s}\right.$-person). Assuming typical restaurant dining room occupancy rates of 70 people per 1000 gross square feet, the minimum ventilation rate for the baseline dining zone would be $880 \mathrm{cfm}$ $\left(0.42 \mathrm{~m}^{3} / \mathrm{s}\right)$. It is confirmed that the selected dining outdoor air of $2080 \mathrm{cfm}$ in Table 3.22 is more than the minimum requirement from Standard 62.1.

\subsubsection{Building HVAC Operating Schedules}

The HVAC system operating schedules are based on the building occupancy. The system is scheduled "on" one hour prior to occupancy to precondition the space, and the system is scheduled "off" one hour after most occupants leave. When the system is "on," the fan runs continuously to supply the required ventilation air, while the compressor and furnace cycle on and off to meet the building's cooling and heating loads. During off hours, the system will shut off and only cycle "on" when the setback thermostat control calls for heating or cooling to maintain the setback temperature. A single HVAC system schedule is used for all the packaged units in the building as shown in Figure 3.11.

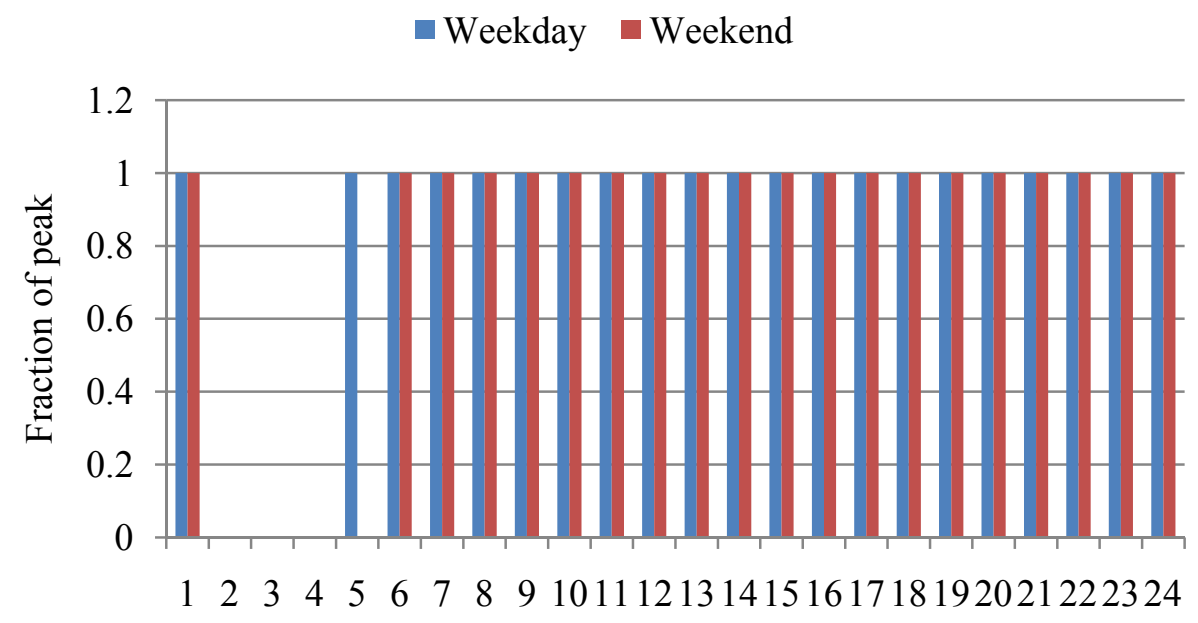

Hours

Figure 3.11. Baseline HVAC System Operating Schedule (1 means the system is "on;" 0 means the system is "off") 


\subsubsection{Heating and Cooling Thermostat Set Point}

The HVAC systems maintain a $70^{\circ} \mathrm{F}\left(21^{\circ} \mathrm{C}\right)$ heating set point and a $75^{\circ} \mathrm{F}\left(24^{\circ} \mathrm{C}\right)$ cooling set point for both the dining and kitchen zones during occupied hours. During off hours, a thermostat setback control strategy also is applied in the baseline prototypes, assuming a $60^{\circ} \mathrm{F}\left(16^{\circ} \mathrm{C}\right)$ heating set point and an $86^{\circ} \mathrm{F}$ $\left(30^{\circ} \mathrm{C}\right)$ cooling set point for both the dining and kitchen zones. A one-hour optimal start control is used in the baseline model for both the heating and cooling seasons. It is implemented in EnergyPlus model by setting a $65^{\circ} \mathrm{F}\left(18^{\circ} \mathrm{C}\right)$ heating set point and an $80^{\circ} \mathrm{F}\left(27^{\circ} \mathrm{C}\right)$ cooling set point for both zones at one hour before the occupied hours.

\subsubsection{HVAC Equipment Sizing}

HVAC equipment sizing refers to the method used to determine the design capacity of the DX cooling coil, furnace, and supply fan airflow in the packaged rooftop units. EnergyPlus allows users to use a "design-day" simulation method for sizing equipment. When using the design-day simulation method, two separate design-day inputs are specified - one for heating and one for cooling. The program determines the design peak loads by simulating the buildings for a 24-hour period on each of the design days. The design peak loads are then used by the subprogram for sizing HVAC equipment. This analysis uses the design-day sizing method primarily for two reasons: 1) it is common practice for designers to choose the design-day method for sizing the HVAC equipment, and 2) using the design-day method will prevent equipment oversizing to meet the extreme peak weather conditions occurring for a very short period of time during a year.

The design-day data for all 16 climate locations were developed based on the "weather data" contained in the accompanying CD-ROM of ASHRAE 2009 Handbook of Fundamentals (ASHRAE 2009). In this data set, the heating design-day condition is based on the 99.6 annual percentile frequency of occurrence. The 99.6 annual percentile means that the dry-bulb temperature equals or is below the heating design condition for 35 hours per year in cold conditions. Similarly, the annual cooling design condition is based on dry-bulb temperature corresponding to $1 \%$ annual cumulative frequency of occurrence in warm conditions. A $1 \%$ value of occurrence means that the dry-bulb temperature equals or exceeds the cooling design condition for 88 hours per year. Additionally, the range of the dry-bulb temperature for summer is in compliance with ASHRAE Standard 90.1-2004. In EnergyPlus simulations, design day schedules also can be specified. To be consistent with the general design practice for HVAC equipment sizing, the internal loads (i.e., occupancy, lights, and plug loads) were scheduled as zero on the heating design day, and as maximum level on the cooling design day.

\subsubsection{HVAC Equipment Efficiency}

Standard 90.1-2004 specifies HVAC equipment efficiency based on heating and cooling capacities. For single packaged equipment with cooling capacities less than $65,000 \mathrm{Btu} / \mathrm{hr}(19 \mathrm{~kW})$, efficiency is rated by seasonal energy efficiency ratio (SEER), which represents an average efficiency throughout the year. SEER is defined as the total cooling output of an air conditioner during its normal annual usage period for cooling (in Btu) divided by the total electric energy during the same period (in Wh). Larger cooling equipment with cooling capacities greater than $65,000 \mathrm{Btu} / \mathrm{hr}(19 \mathrm{~kW})$ is rated by energy efficiency ratio (EER), which represents efficiency at a particular design condition, and is defined as the ratio of net cooling capacity in Btu/hr to total rate of electric input in Watts at rated conditions. 
When determining efficiency requirements, the standard allows air conditioning units with a heating section other than electric resistance to take a credit of 0.2 , which is subtracted from the required EER. In EnergyPlus, the efficiency of air conditioners is indicated by entering a coefficient of performance (COP), which is defined as the cooling power output in Watts divided by the electrical power input in Watts determined at the same environmental conditions as the EER. However, unlike EER, the COP input in EnergyPlus does not include the rated power consumption of the supply air fan, so an adjustment to the EER is needed to remove the effect of the indoor fan energy. In addition, for equipment rated by SEER, a conversion from SEER is also required (Wassmer and Brandemuehl 2006). The COP input in EnergyPlus is determined by the following equations.

$$
\begin{gathered}
\mathrm{EER}=-0.0182 \times \mathrm{SEER}^{2}+1.1088 \times \mathrm{SEER} \\
\mathrm{COP}=(\mathrm{EER} / 3.413+\mathrm{R}) /(1-\mathrm{R})
\end{gathered}
$$

where $\mathrm{R}$ is the ratio of supply fan power to total equipment power at the rating condition.

Typical values of fan power ratio $\mathrm{R}$ for a commercial rooftop unit vary from about 0.05 to 0.17 depending on specific product design choices. For this analysis, we assume a ratio of about 0.12 as being representative of the broad class of products (PNNL 2004). Table 3.23 shows the cooling efficiency requirements for the HVAC equipment in the QSR building and the calculated COP for input in the EnergyPlus model.

Table 3.23. Single Packaged Air Conditioner Baseline Efficiency

\begin{tabular}{lcc}
\hline \multicolumn{1}{c}{ Size Category } & $\begin{array}{c}\text { Minimum Efficiency from } \\
\text { Standard } 90.1-2004\end{array}$ & $\begin{array}{c}\text { Efficiency as Input } \\
\text { in EnergyPlus }\end{array}$ \\
\hline$<65,000 \mathrm{Btu} / \mathrm{h}(<19 \mathrm{~kW})$ & 13.0 SEER & $3.91 \mathrm{COP}$ \\
$65,000 \sim 135,000 \mathrm{Btu} / \mathrm{h}(19 \sim 40 \mathrm{~kW})$ & 10.1 EER & $3.50 \mathrm{COP}$ \\
$135,000 \sim 240,000 \mathrm{Btu} / \mathrm{h}(40 \sim 70 \mathrm{~kW})$ & 9.5 EER & $3.30 \mathrm{COP}$ \\
$240,000 \sim 760,000 \mathrm{Btu} / \mathrm{h}(70 \sim 223 \mathrm{~kW})$ & 9.3 EER & $3.23 \mathrm{COP}$ \\
$\geq 760,000 \mathrm{Btu} / \mathrm{h}(\geq 223 \mathrm{~kW})^{(\mathrm{a})}$ & 9.0 EER & $3.13 \mathrm{COP}$ \\
\hline
\end{tabular}

(a) This size category is not applicable for QSR prototype.

Gas furnaces less than $225,000 \mathrm{Btu} / \mathrm{hr}(66 \mathrm{~kW})$ are rated by average fuel utilization efficiency (AFUE), which, like SEER, represents average annual efficiency. The efficiency requirement for these units is $78 \%$ AFUE. Furnaces larger than $225,000 \mathrm{Btu} / \mathrm{hr}(66 \mathrm{~kW})$ must meet an $80 \%$ combustion efficiency $\left(\mathrm{E}_{\mathrm{c}}\right)$.

\subsubsection{HVAC System Fan Power}

EnergyPlus uses total static pressure, fan efficiency, fan motor efficiency and fan flow rate to calculate supply fan power. One way to estimate the total static pressure is to use the maximum fan power allowance for fans with motor exceeding $5 \mathrm{hp}(3.73 \mathrm{~kW})$, which is specified in ASHRAE Standard 90.1-2004. However, this method was not used in this study because the calculated static pressure was excessive for typical QSRs. Based on data from the Dodge Drawings, a common design pressure drop of a 2.5-in. w.c. (623 Pa), was used for supply fans in the baseline buildings. The baseline buildings used 
the fan efficiency of 55\% as an input which is also used by the ASHREA 90.1 SSPC while developing fan power requirements for the Standard. The last required input, motor efficiency, is taken directly from Table 10.8 of Standard 90.1- 2004, based on motor nameplate size, assuming enclosed motors operating at $1,800 \mathrm{rpm}$.

As discussed in Section 3.4.1, an EnergyPlus object, ZoneMixing, is used to model the transfer air from dining zone to kitchen, which is to partially replace the exhausted air through kitchen hoods in reality. However, the ZoneMixing object only affects the energy balance of the receiving zone (kitchen) and it does not affect on the source zone (dining). The flow within the two zones has to be balanced by adding a zero-energy virtual exhaust fan in the dining and by reducing the designed exhaust flow in the receiving zone by the amount of transfer air. In order to properly account for the energy from the three actual exhaust fans, they are all simulated as plug load equipment and their power is calculated as shown in Table 3.24.

Table 3.24. Baseline Exhaust Fan Energy Calculation

\begin{tabular}{lcccc}
\hline Exhaust Fan Name & $\begin{array}{c}\text { Total Static Pressure, } \\
\text { in. w.c. }(\mathrm{Pa})\end{array}$ & $\begin{array}{c}\text { Flow Rate, } \\
\mathrm{cfm}\left(\mathrm{m}^{3} / \mathrm{s}\right)\end{array}$ & $\begin{array}{c}\text { Total Fan } \\
\text { Efficiency }\end{array}$ & $\begin{array}{c}\text { Power, } \\
\text { W }\end{array}$ \\
\hline Restroom exhaust fan & $0.5(125)$ & $400(0.19)$ & $30 \%$ & 78 \\
Kitchen exhaust fan 1 & $1.25(311)$ & $2300(1.09)$ & $60 \%$ & 562 \\
Kitchen exhaust fan 2 & $1.25(311)$ & $2300(1.09)$ & $60 \%$ & 562 \\
\hline
\end{tabular}

\subsubsection{Economizer Use}

Standard 90.1- 2004 does not require economizers if the system cooling capacity is less than $65,000 \mathrm{Btu} / \mathrm{hr}(19 \mathrm{~kW})$ regardless of climate zone. For cooling capacities greater than $65,000 \mathrm{Btu} / \mathrm{hr}$ $(19 \mathrm{~kW})$, economizers are required depending on the climate zone and the capacity. Table 3.25 shows the economizer requirements of Standard 90.1-2004 for the 16 representative cities. For those baseline buildings in which the air systems have cooling capacity large enough to trigger the use of an air economizer, the applicable systems are modeled with economizer controlled by differential dry-bulb temperature. Under this control scenario, when the outdoor air temperature is below the return air temperature, the economizer is enabled. Gravity dampers are simulated as being open to minimum position whenever the supply fan is running, even when the building is unoccupied.

Table 3.25. Economizer Requirements in Standard 90.1-2004

\begin{tabular}{llcc}
\hline $\begin{array}{c}\text { Climate } \\
\text { Zone }\end{array}$ & Representative City & $\begin{array}{c}\text { Economizer Required if Cooling } \\
\text { Capacity } \geq 65,000 \mathrm{Btu} / \mathrm{h}(19 \mathrm{~kW}) \text { and } \\
<135,000 \mathrm{Btu} / \mathrm{h}(40 \mathrm{~kW})\end{array}$ & $\begin{array}{c}\text { Economizer Required if Cooling } \\
\text { Capacity } \geq 135,000 \mathrm{Btu} / \mathrm{h}(40 \mathrm{~kW})\end{array}$ \\
\hline 1A & Miami & No & No \\
$2 \mathrm{~A}$ & Houston & No & No \\
2B & Phoenix & No & Yes \\
3A & Atlanta & No & No \\
3B-CA & Los Angeles & Yes & Yes \\
3B-other & Las Vegas & Yes & Yes \\
3C & San Francisco & Yes & Yes \\
\hline
\end{tabular}


Table 3.25. (cont'd)

\begin{tabular}{llcc}
\hline $\begin{array}{c}\text { Climate } \\
\text { Zone }\end{array}$ & Representative City & $\begin{array}{c}\text { Economizer Required if Cooling } \\
\text { Capacity } \geq 65,000 \mathrm{Btu} / \mathrm{h}(19 \mathrm{~kW}) \text { and } \\
<135,000 \mathrm{Btu} / \mathrm{h}(40 \mathrm{~kW})\end{array}$ & $\begin{array}{c}\text { Economizer Required if Cooling } \\
\text { Capacity } \geq 135,000 \mathrm{Btu} / \mathrm{h}(40 \mathrm{~kW})\end{array}$ \\
\hline 4A & Baltimore & No & No \\
4B & Albuquerque & Yes & Yes \\
4C & Seattle & Yes & Yes \\
5A & Chicago & No & Yes \\
5B & Denver & Yes & Yes \\
6A & Minneapolis & No & Yes \\
6B & Helena & Yes & Yes \\
7 & Duluth & No & Yes \\
8 & Fairbanks & No & Yes \\
\hline
\end{tabular}

\subsection{Service Hot Water System}

In QSRs, the hot water usages are primarily for dish sanitation, store cleanup, and hand washing in the kitchen and restrooms. QSRs normally use disposable containers; therefore, dish washing is not as significant of a load.

In EnergyPlus, the "WaterHeater:Mixed" object was used to estimate the service hot water energy consumption. To estimate the energy performance of a water heater with a storage tank, the EnergyPlus program requires the user to define the following key input variables as the operating parameters:

- Storage tank size

- Peak hot water flow rate and load profile (schedule)

- Hot water setpoint temperature

- Heater input capacity and thermal efficiency

- Standby heat loss coefficient (UA).

\subsubsection{Hot Water Usage and Storage Tank Size}

Average hot water consumption varies significantly among individual QSRs, ranging from 250 to 1200 gallon per day (Delagah and Fisher 2010). Based on field monitoring, the average "burger-based" QSR is estimated to use 500 gallon per day (FSTC 2007). The peak hourly hot water demand is $82 \mathrm{gal} / \mathrm{h}$ $(5.17 \mathrm{~L} / \mathrm{s})$. This is based on field-monitored data using a typical hot water load profile on an average weekday (see Figure 3.12). 


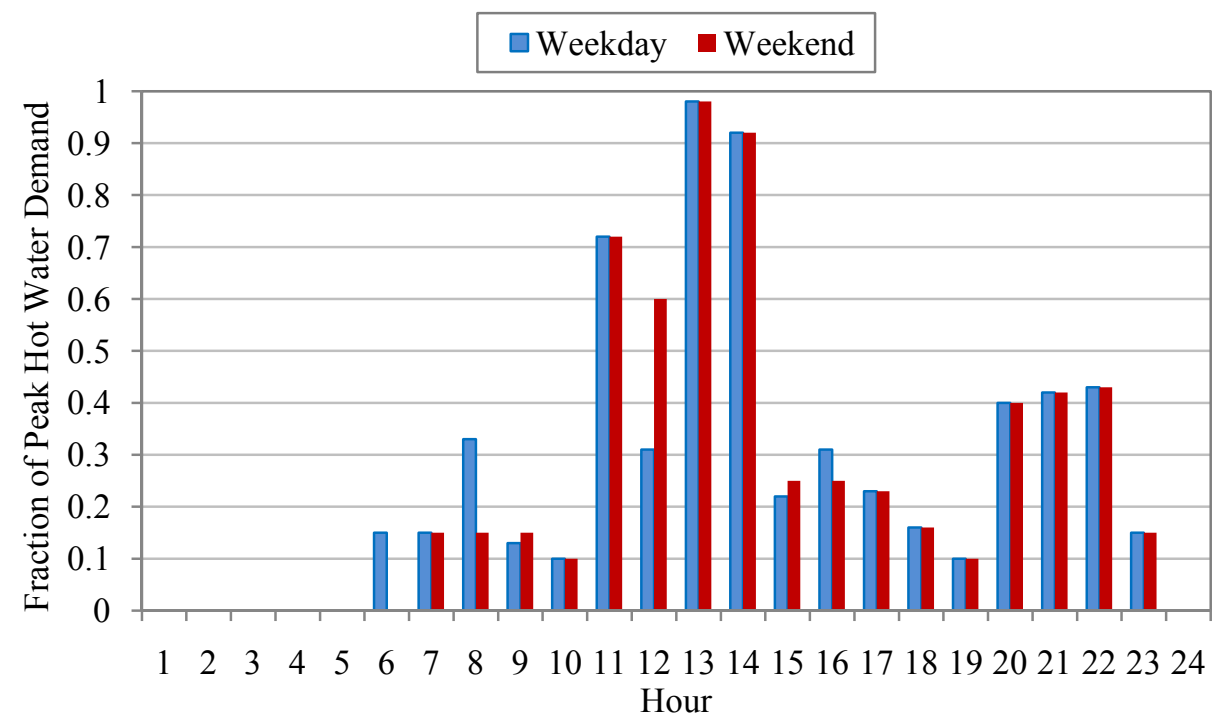

Figure 3.12. Hot Water Load Profile for Baseline QSR Model

Eight of the 10 restaurants listed in Table 3.26 specify storage water heaters, and the capacity of most of these units is close to $100 \mathrm{gal}(379 \mathrm{~L})$. As a result, a 100-gal storage tank is selected for the QSR prototype model. The hot water supply temperature is set to $140^{\circ} \mathrm{F}\left(60^{\circ} \mathrm{C}\right)$.

Table 3.26. QSR Service Hot Water Design Capacity Summary

\begin{tabular}{lcccccccc}
\hline \multicolumn{1}{c}{ QSR Name } & $\begin{array}{c}\text { Water } \\
\text { Heater } \\
\text { Type }\end{array}$ & $\begin{array}{c}\text { Fuel } \\
\text { source }\end{array}$ & $\begin{array}{c}\text { Storage } \\
\text { QTY }\end{array}$ & $\begin{array}{c}\text { Rated } \\
(\mathrm{gal})\end{array}$ & $\begin{array}{c}\text { Recovery } \\
(\mathrm{kBtu} / \mathrm{h})\end{array}$ & $\begin{array}{c}\text { Temp. } \\
\text { Capacity } \\
(\mathrm{gph})\end{array}$ & $\begin{array}{c}\text { Hot Water } \\
\text { Rise } \\
\left({ }^{\circ} \mathrm{F}\right)\end{array}$ & $\begin{array}{c}\text { Setting } \\
\left({ }^{\circ} \mathrm{F}\right)\end{array}$ \\
\hline Brand 1A & Storage & Gas & 1 & 100 & 150 & 180 & 100 & $110 / 140$ \\
Brand 1B, Tank A & Storage & Gas & 1 & 75 & 160 & 155 & 100 & NA \\
Brand 1B, Tank B & Storage & Electric & 1 & 12 & 5.1 & 6 & 100 & NA \\
Brand 2 & Storage & Gas & 1 & 100 & 199 & 214 & 90 & 140 \\
Brand 3 & Tankless & Gas & 1 & NA & 179 & 116 & 100 & NA \\
Brand 4 & Storage & Gas & 1 & 50 & 100 & 112 & 100 & NA \\
Brand 5A & Storage & Gas & 1 & 100 & 150 & 171 & 100 & 140 \\
Brand 6 & Storage & Gas & 1 & 90 & 150 & 149 & 100 & 140 \\
Brand 7 & Storage & Gas & 1 & 80 & 198 & 226 & 100 & $110 / 140$ \\
Brand 5B & Tankless & Gas & 1 & NA & 160 & 360 & 40 & $120 / 140$ \\
Brand 8 & Storage & Gas & 1 & 100 & 200 & 239 & 100 & NA \\
\hline
\end{tabular}

\subsubsection{Heater Input Capacity, Thermal Efficiency, and Standby Heat Loss}

For commercial gas storage water heaters, the minimum performance required is expressed as two values, thermal efficiency $\left(E_{t}\right)$ and the standby loss $(\mathrm{SL})$. As shown in Table 3.26 the rated power input of the heaters ranges from 100 to $200 \mathrm{kBtu} / \mathrm{h}(29.3$ to $58.6 \mathrm{~kW})$. For a water heater with rated input larger than $75 \mathrm{kBtu} / \mathrm{h}(22.0 \mathrm{~kW})$, the minimum $\mathrm{E}_{\mathrm{t}}$ required is $80 \%$ as defined by Standard $90.1-2004$. The maximum standby loss SL is $1288 \mathrm{Btu} / \mathrm{hr}(0.38 \mathrm{~kW})$ using following equation required in the standard: 


$$
S L=\frac{Q}{800}+110 \sqrt{V}
$$

where: $\quad$ SL $\quad=$ standby heat loss $(\mathrm{Btu} / \mathrm{h})$

$\mathrm{Q}=$ rated input power $(\mathrm{Btu} / \mathrm{h})$

$\mathrm{V}=$ rated storage tank volume $(\mathrm{gal})$

Based on equipment specifications from commercial water heater manufacturers and reviews of AHRI's Directory of Certified Product Performance database, ${ }^{1}$ the average standby heat loss rating of a $100 \mathrm{gal}(379 \mathrm{~L})$ gas water heater with an input rating of $150,000 \mathrm{Btu} / \mathrm{h}(44.0 \mathrm{~kW})$ is $1200 \mathrm{Btu} / \mathrm{h}$. Thus, the standby heat loss coefficient (UA) of this commercial heater was determined using the following equation:

$$
U A=\frac{S L \times R E}{70}
$$

where $\quad \mathrm{UA}=$ standby heat loss coefficient $\left(\mathrm{Btu} / \mathrm{h} \cdot{ }^{\circ} \mathrm{F}\right)$

$\mathrm{SL}=$ standby heat loss $(\mathrm{Btu} / \mathrm{h})$

$\mathrm{RE} \quad=$ recovery efficiency/thermal efficiency

$70=$ difference in temperature between stored water thermostat set point and ambient air temperature at the test condition $\left({ }^{\circ} \mathrm{F}\right)$

Inserting the appropriate values for $\mathrm{SL}$ and $\mathrm{RE}$, results in a $\mathrm{UA}$ of $13.7 \mathrm{Btu} / \mathrm{h}-{ }^{\circ} \mathrm{F}(7.23 \mathrm{~W} / \mathrm{K})$, as one of the input variables for the QSR model in the EnergyPlus program. The EnergyPlus program can automatically calculate the rated input capacity of the water heaters based on the peak design conditions. The calculated capacity is $150 \mathrm{kBtu} / \mathrm{h}(44.0 \mathrm{~kW})$. The service hot water system model has been calibrated to accurately reflect the daily hot water load profile, daily hot water consumption, and the peak usage.

\footnotetext{
${ }^{1}$ Directory of Certified Product Performance. Retrieved September 2010, from http://www.ahridirectory.org/ahriDirectory/pages/home.aspx
} 


\subsection{Advanced Low-Energy Use Building Models}

The advanced building models are developed by simulating the effects of various energy EEMs on the annual energy performance of the QSR building models. Because the 16 baseline QSR models cover a wide range of climates, the EEMs are location specific. The EEM concepts are developed based on a number of resources including the approved and proposed addenda to ASHRAE Standard 90.1-2007, the previously published TSDs and ADEGs such as Jiang et al. (2009), Thornton et al. (2009), and Thornton et al. (2010), the authors' professional experience, and input from industry experts. The following three factors were considered fully when developing the EEMs. First, the EEMs should be based on technologies that are commercially available from multiple sources. Second, the EEMs can be modeled directly or via a work-around approach by the current version (v5.0) of EnergyPlus. Third, the EEM packages should result in a simple payback within 5 years. It should be noted that the cost analysis mainly focused on the whole EEM package rather than individual EEMs. In other words, an individual EEM not meeting the 5 year simple payback criteria may still be included in the final EEM package. All proposed EEMs can be grouped into the following categories:

- Building envelope measures such as an enhanced building opaque envelope insulation, highperformance windows, a cool roof, etc.

- Lighting measures that reduce connected lighting load and use advanced automatic lighting controls such as daylight harvesting and occupancy based controls

- Commercial kitchen measures that use efficient cooking appliances and refrigeration equipment

- HVAC measures such as dedicated outdoor air conditioning system (DOAS), efficient exhaust hoods for the main cook line, demand-controlled ventilation for kitchen exhaust hoods, high-efficiency cooling and heating systems, and air-to-air heat recovery through coil energy recovery (runaround) loop

- Service water heating measures such as higher-efficiency equipment and heat recovery from the refrigeration system.

\subsection{Envelope}

Advanced building models incorporate various EEMs while maintaining the same building form, orientation, total window area, and wall and roof construction types as those used in the baseline cases. In comparison with the baseline, the advanced models incorporate the following building envelope related energy efficiency measures: enhanced insulation for opaque assemblies, high-performance windows, and a reflecting cool roof.

\subsubsection{Enhanced Insulation for Opaque Assemblies}

The advanced insulation requirements for exterior walls, roof, and slab floor are based on the second public review draft of Addendum BB to ASHRAE Standard 90.1-2007. Baseline values are the nonresidential values from Standard 90.1-2004. Exterior walls are the same wood-framed wall construction type as those in the baseline (see Section 3.1), but more continuous rigid board insulation is added to improve the overall thermal performance. Table 4.1 shows the required wall assembly U-factors and the corresponding insulation R-values for both baseline and advanced models. Roofs have insulation entirely 
above metal deck construction type with enhanced insulation. Table 4.2 shows the required roof assembly U-factors and the corresponding rigid insulation R-values. Table 4.3 shows the required slabon-grade insulation F-factors and the corresponding rigid insulation R-values.

Table 4.1. Required Thermal Performance for Exterior-Above-Grade, Wood-Framed Walls

\begin{tabular}{|c|c|c|c|c|c|c|c|c|}
\hline \multirow{3}{*}{$\begin{array}{l}\text { Climate } \\
\text { Zone }\end{array}$} & \multicolumn{4}{|c|}{ Baseline } & \multicolumn{4}{|c|}{ Advanced } \\
\hline & \multicolumn{2}{|c|}{$\begin{array}{l}\text { Assembly maximum } \\
\text { U-factor }\end{array}$} & \multicolumn{2}{|c|}{$\begin{array}{l}\text { Insulation minimum } \\
\text { R-value }\end{array}$} & \multicolumn{2}{|c|}{$\begin{array}{l}\text { Assembly maximum } \\
\text { U-factor }\end{array}$} & \multicolumn{2}{|c|}{$\begin{array}{l}\text { Insulation minimum } \\
\text { R-value }\end{array}$} \\
\hline & $\mathrm{Btu} / \mathrm{h} \bullet \mathrm{ft}^{2} \cdot{ }^{\circ} \mathrm{F}$ & $\mathrm{W} / \mathrm{m}^{2} \cdot{ }^{\circ} \mathrm{C}$ & $\mathrm{h} \cdot \mathrm{ft}^{2} \cdot \mathrm{F} / \mathrm{Btu}$ & $\mathrm{m}^{2} \cdot{ }^{\circ} \mathrm{C} / \mathrm{W}$ & $\mathrm{Btu} / \mathrm{h} \cdot \mathrm{ft}^{2} \cdot{ }^{\circ} \mathrm{F}$ & $\mathrm{W} / \mathrm{m}^{2} \cdot{ }^{\circ} \mathrm{C}$ & $\mathrm{h} \cdot \mathrm{ft}^{2} \cdot \mathrm{F} / \mathrm{Btu}$ & $\mathrm{m}^{2} \cdot{ }^{\circ} \mathrm{C} / \mathrm{W}$ \\
\hline 1 & 0.089 & 0.50 & 13 & 2.3 & 0.089 & 0.50 & 13 & 2.3 \\
\hline 2 & 0.089 & 0.50 & 13 & 2.3 & 0.064 & 0.37 & $13+3.8$ c.i. & $2.3+0.7$ c.i. \\
\hline 3 & 0.089 & 0.50 & 13 & 2.3 & 0.064 & 0.37 & $13+3.8$ c.i. & $2.3+0.7$ c.i. \\
\hline 4 & 0.089 & 0.50 & 13 & 2.3 & 0.051 & 0.29 & $13+7.5$ c.i. & $2.3+1.3$ c.i. \\
\hline 5 & 0.089 & 0.50 & 13 & 2.3 & 0.045 & 0.26 & $13+10$ c.i. & $2.3+1.8$ c.i. \\
\hline 6 & 0.089 & 0.50 & 13 & 2.3 & 0.040 & 0.23 & $13+12.5$ c.i. & $2.3+2.2$ c.i. \\
\hline 7 & 0.089 & 0.50 & 13 & 2.3 & 0.037 & 0.21 & $13+15$ c.i. & $2.3+2.6$ c.i. \\
\hline 8 & 0.051 & 0.29 & $13+7.5$ c.i. & $2.3+1.3$ c.i. & 0.032 & 0.18 & $13+18.8$ c.i. & $2.3+3.3$ c.i. \\
\hline
\end{tabular}

c.i. $=$ continuous insulation

Table 4.2. Required Thermal Performance for Roofs with Insulation Entirely Above Deck

\begin{tabular}{|c|c|c|c|c|c|c|c|c|}
\hline \multirow{3}{*}{$\begin{array}{l}\text { Climate } \\
\text { Zone }\end{array}$} & \multicolumn{4}{|c|}{ Baseline } & \multicolumn{4}{|c|}{ Advanced } \\
\hline & \multicolumn{2}{|c|}{$\begin{array}{c}\text { Assembly maximum } \\
\text { U-factor }\end{array}$} & \multicolumn{2}{|c|}{$\begin{array}{l}\text { Insulation minimum } \\
\text { R-value } \\
\text { (continuous insulation) }\end{array}$} & \multicolumn{2}{|c|}{$\begin{array}{l}\text { Assembly maximum } \\
\text { U-factor }\end{array}$} & \multicolumn{2}{|c|}{$\begin{array}{c}\text { Insulation minimum } \\
\text { R-value } \\
\text { (continuous insulation) }\end{array}$} \\
\hline & $\mathrm{Btu} / \mathrm{h} \cdot \mathrm{ft}^{2} \bullet{ }^{\circ} \mathrm{F}$ & $\mathrm{W} / \mathrm{m}^{2} \cdot{ }^{\circ} \mathrm{C}$ & $\mathrm{h} \cdot \mathrm{ft}^{2} \cdot \mathrm{F} / \mathrm{Btu}$ & $\mathrm{m}^{2} \cdot{ }^{\circ} \mathrm{C} / \mathrm{W}$ & $\mathrm{Btu} / \mathrm{h} \cdot \mathrm{ft}^{2} \cdot{ }^{\circ} \mathrm{F}$ & $\mathrm{W} / \mathrm{m}^{2} \cdot{ }^{\circ} \mathrm{C}$ & $\mathrm{h} \cdot \mathrm{ft}^{2} \cdot \mathrm{F} / \mathrm{Btu}$ & $\mathrm{m}^{2} \cdot{ }^{\circ} \mathrm{C} / \mathrm{W}$ \\
\hline 1 & 0.063 & 0.36 & 15 & 2.6 & 0.048 & 0.27 & 20 & 3.5 \\
\hline 2 & 0.063 & 0.36 & 15 & 2.6 & 0.039 & 0.22 & 25 & 4.4 \\
\hline 3 & 0.063 & 0.36 & 15 & 2.6 & 0.039 & 0.22 & 25 & 4.4 \\
\hline 4 & 0.063 & 0.36 & 15 & 2.6 & 0.032 & 0.18 & 30 & 5.3 \\
\hline 5 & 0.063 & 0.36 & 15 & 2.6 & 0.032 & 0.18 & 30 & 5.3 \\
\hline 6 & 0.063 & 0.36 & 15 & 2.6 & 0.032 & 0.18 & 30 & 5.3 \\
\hline 7 & 0.063 & 0.36 & 15 & 2.6 & 0.028 & 0.16 & 35 & 6.2 \\
\hline 8 & 0.048 & 0.27 & 20 & 3.5 & 0.028 & 0.16 & 35 & 6.2 \\
\hline
\end{tabular}


Table 4.3. Required Thermal Performance for a Slab-On-Grade Unheated Floor

\begin{tabular}{|c|c|c|c|c|c|c|c|c|}
\hline \multirow{3}{*}{$\begin{array}{l}\text { Climate } \\
\text { Zone }\end{array}$} & \multicolumn{4}{|c|}{ Baseline } & \multicolumn{4}{|c|}{ Advanced } \\
\hline & \multicolumn{2}{|c|}{$\begin{array}{c}\text { Assembly Maximum } \\
\text { F-factor }\end{array}$} & \multicolumn{2}{|c|}{$\begin{array}{c}\text { Insulation R-value for } \\
24 \text { in. }(600 \mathrm{~mm}) \\
\text { vertical }\end{array}$} & \multicolumn{2}{|c|}{$\begin{array}{c}\text { Assembly Maximum } \\
\text { F-factor }\end{array}$} & \multicolumn{2}{|c|}{$\begin{array}{c}\text { Insulation R-value for } \\
24 \text { in. }(600 \mathrm{~mm}) \\
\text { vertical }\end{array}$} \\
\hline & $\mathrm{Btu} / \mathrm{h} \cdot \mathrm{ft} \cdot{ }^{\circ} \mathrm{F}$ & $\mathrm{W} / \mathrm{m}^{2} \cdot \mathrm{K}$ & $\mathrm{h} \cdot \mathrm{ft}^{2} \cdot \mathrm{F} / \mathrm{Btu}$ & $\mathrm{m}^{2} \cdot \mathrm{K} / \mathrm{W}$ & $\mathrm{Btu} / \mathrm{h} \cdot \mathrm{ft} \cdot{ }^{\circ} \mathrm{F}$ & $\mathrm{W} / \mathrm{m}^{2} \cdot \mathrm{K}$ & $\mathrm{h} \bullet \mathrm{ft}^{2} \cdot \mathrm{F} / \mathrm{Btu}$ & $\mathrm{m}^{2} \cdot \mathrm{K} / \mathrm{W}$ \\
\hline 1 & 0.73 & 1.264 & NR & NR & 0.73 & 1.26 & NR & NR \\
\hline 2 & 0.73 & 1.264 & NR & NR & 0.73 & 1.26 & NR & NR \\
\hline 3 & 0.73 & 1.264 & NR & NR & 0.73 & 1.26 & NR & NR \\
\hline 4 & 0.73 & 1.264 & NR & NR & 0.52 & 0.90 & 15 & 2.6 \\
\hline 5 & 0.73 & 1.264 & NR & NR & 0.52 & 0.90 & 15 & 2.6 \\
\hline 6 & 0.73 & 1.264 & NR & NR & 0.51 & 0.88 & 20 & 3.5 \\
\hline 7 & 0.73 & 1.264 & NR & NR & 0.51 & 0.88 & 20 & 3.5 \\
\hline 8 & 0.54 & 0.935 & 10 & 1.76 & 0.434 & 0.75 & $20 *$ & $3.5^{1}$ \\
\hline
\end{tabular}

\subsubsection{High-Performance Windows}

The advanced models maintain the same window area as the baseline model, but change the window construction and physical layout to have improved performance in terms of the U-factor and the SHGC value as well as a reduction in lighting energy through daylight harvesting. After the change of window layout, two types of windows are used in the advanced model - view windows and daylight windows. The targeted U-factor and SHGC values of the view and daylight windows are from the public review draft of Addendum BB to Standard 90.1-2007. As noted under the baseline, the analysis is based on the understanding that typical QSR fenestration use manufactured windows in punch style openings. Section 4.2.1.4 describes the changes made to the physical layout of windows and glazing type to harvest daylighting potential. In Table 4.4, the baseline U-factor and SHGC values are presented along with the advanced values to facilitate comparison. Addendum BB to Standard 90.1-2007 has separate values for different framing types, and the advanced values shown are based on an estimated weighting of $9.9 \%$ non-metal framing, $88.7 \%$ fixed-metal framing, and 1.4\% operatable-metal framing. ${ }^{1}$

Table 4.4. Required Performance for Fenestration U-factor, SHGC, and VT Values

\begin{tabular}{|c|c|c|c|c|c|c|c|c|}
\hline \multirow{3}{*}{$\begin{array}{l}\text { Climate } \\
\text { Zone }\end{array}$} & \multicolumn{4}{|c|}{ Baseline } & \multicolumn{4}{|c|}{ Advanced } \\
\hline & \multicolumn{2}{|c|}{$\begin{array}{c}\text { Assembly maximum } \\
\text { U-factor }\end{array}$} & \multirow[b]{2}{*}{ SHGC } & \multirow[b]{2}{*}{ VT/SHGC } & \multicolumn{2}{|c|}{$\begin{array}{c}\text { Assembly maximum } \\
\text { U-factor }\end{array}$} & \multirow[b]{2}{*}{ SHGC } & \multirow[b]{2}{*}{ VT/SHGC } \\
\hline & $\mathrm{Btu} / \mathrm{h} \cdot \mathrm{ft}^{2} \cdot{ }^{\circ} \mathrm{F}$ & $\mathrm{W} / \mathrm{m}^{2} \cdot \mathrm{K}$ & & & $\mathrm{Btu} / \mathrm{h} \cdot \mathrm{ft}^{2} \bullet^{\circ} \mathrm{F}$ & $\mathrm{W} / \mathrm{m}^{2} \cdot \mathrm{K}$ & & \\
\hline 1 & 1.22 & 6.93 & 0.25 & NR & 0.71 & 4.03 & 0.25 & 1.1 \\
\hline 2 & 1.22 & 6.93 & 0.25 & NR & 0.49 & 2.78 & 0.25 & 1.1 \\
\hline $3 \mathrm{~A}, 3 \mathrm{~B}$ & 0.57 & 3.24 & 0.25 & NR & 0.45 & 2.55 & 0.25 & 1.1 \\
\hline $3 \mathrm{C}$ & 1.22 & 6.93 & 0.39 & NR & 0.45 & 2.55 & 0.30 & 1.1 \\
\hline 4 & 0.57 & 3.24 & 0.39 & NR & 0.38 & 2.16 & 0.30 & 1.1 \\
\hline 5 & 0.57 & 3.24 & 0.39 & NR & 0.38 & 2.16 & 0.30 & 1.1 \\
\hline 6 & 0.57 & 3.24 & 0.39 & NR & 0.36 & 2.04 & 0.35 & 1.1 \\
\hline 7 & 0.57 & 3.24 & 0.49 & NR & 0.29 & 1.65 & 0.40 & 1.1 \\
\hline 8 & 0.46 & 2.61 & 0.45 & NR & 0.29 & 1.65 & 0.40 & 1.1 \\
\hline
\end{tabular}

\footnotetext{
${ }^{1}$ The ASHRAE SSPC 90.1 Envelope Subcommittee provided the estimated weighting factor based on Ducker Fenestration Market Data.
} 
As described in Section 3.1.4, in the current version of EnergyPlus, a window's performance, including the U-factor and SHGC values, are derived from the solar-optical properties of the glazing layers. The windows for the advanced case are modeled using the hypothetical glass library as described in Section 3.1.4, and they match or very nearly match the performance values in the table above. The effects of window frame and dividers are not modeled explicitly.

\subsubsection{Cool Roof}

A cool roof that reflects solar energy can be an effective EEM in hot climates (Konopacki and Akbari 2001; Jarnagin et al. 2006). Therefore, in the advanced models, the exterior layer of the roof system is modeled as a light colored, reflective roofing membrane (such as white EDPM), which has a solar reflectance of 0.69 and a thermal emittance of 0.87 (LBNL 2010a). In contrast, the exterior roof layer in the baseline models is a gray EPDM, with a solar reflectance of 0.23 and a thermal emittance of 0.87 . Following the AEDG series (Jarnagin et al. 2006; Liu et al. 2007; Jiang et al. 2008; Thornton et al. 2010), a cool roof is included only in climate Zones 1 through 3.

\subsection{Lighting}

The implemented EEMs that address interior lighting include reduced interior LPD, occupancy sensor control, improved lighting power management, and daylighting with dimming control. The EEMs that address exterior lighting include reduced exterior lighting power and exterior lighting control.

\subsubsection{Interior Lighting}

\subsubsection{Reduced Interior Lighting Power Density}

LPD can be reduced via the use of energy-efficient lighting systems and the suitable integration and layout of ambient lighting. In this work, the space-by-space method is followed to determine the interior lighting power allowance. The LPD for the whole building is derived from the percentage of each space type and the designed LPD for each space. For the advanced case, different lighting systems may be used for a given space type. In this case, the designed LPD for each lighting system is estimated also. The information for the LPD calculation is presented in Table 4.5, where the baseline LPD calculation is also provided for comparison. It shows that the LPD can be reduced from $1.44 \mathrm{~W} / \mathrm{ft}^{2}\left(15.49 \mathrm{~W} / \mathrm{m}^{2}\right)$ in the baseline to $0.83 \mathrm{~W} / \mathrm{ft}^{2}\left(8.96 \mathrm{~W} / \mathrm{m}^{2}\right)$ in the advanced case.

\subsubsection{Occupancy Sensor Control of Interior Lighting during Occupied Periods}

Occupancy sensor control is included in the simulation for the private office, active storage, and restroom spaces in the advanced building models. In this study, a detailed analysis was made to quantify the potential of energy savings as a result of occupancy sensor control. Table 4.6 presents the breakdown of the lighting control strategies for each space category, the percentage of lights controlled by occupancy sensors, and the percentage of energy saving potential from occupancy sensors. After calculation, we found that, because of the use of occupancy sensors, the lighting energy use was about $7.16 \%$ less for the advanced case than for the baseline. Thus, in the EnergyPlus simulations for advanced cases, the peak LPD is reduced by $7.16 \%$. Figure 4.1 shows how this $7.16 \%$ reduction is applied during the occupied hours in the lighting schedules between the baseline without occupancy sensors and the advanced case with occupancy sensors. 
Table 4.5. Interior Lighting Power Reduction

\begin{tabular}{|c|c|c|c|c|c|c|c|c|c|}
\hline \multirow[b]{2}{*}{$\begin{array}{l}\text { Space } \\
\text { Type }\end{array}$} & \multirow[b]{2}{*}{$\begin{array}{l}\text { Percent } \\
\text { age of } \\
\text { Floor } \\
\text { Area }^{(a)}\end{array}$} & \multicolumn{4}{|c|}{ Baseline } & \multicolumn{4}{|c|}{ Advance } \\
\hline & & Lighting Systems & $\begin{array}{c}\text { LPD } \\
\text { per } \\
\text { lighting } \\
\text { system } \\
\left(\mathrm{W} / \mathrm{ft}^{2}\right)\end{array}$ & $\begin{array}{c}\text { LPD, } \\
\text { total } \\
\left(\mathrm{W} / \mathrm{ft}^{2}\right)\end{array}$ & $\begin{array}{c}\text { LPD, } \\
\text { total } \\
\left(\mathrm{W} / \mathrm{m}^{2}\right)\end{array}$ & Lighting Systems & $\begin{array}{c}\text { LPD } \\
\text { per } \\
\text { lighting } \\
\text { system } \\
\left(\mathrm{W} / \mathrm{ft}^{2}\right)\end{array}$ & $\begin{array}{c}\text { LPD, } \\
\text { total } \\
\left(\mathrm{W} / \mathrm{ft}^{2}\right)\end{array}$ & $\begin{array}{c}\text { LPD, } \\
\text { total } \\
\left(\mathrm{W} / \mathrm{m}^{2}\right)\end{array}$ \\
\hline \multirow[t]{3}{*}{ Dining } & \multirow[t]{3}{*}{$36 \%$} & CF downlight $(60 \%)$ & 0.76 & \multirow[t]{3}{*}{2.08} & \multirow[t]{3}{*}{22.3} & Linear Direct Lensed $(100 \%)$ & 0.24 & \multirow[t]{3}{*}{0.81} & \multirow[t]{3}{*}{8.7} \\
\hline & & Incandescent Pendant (10\%) & 0.72 & & & $\begin{array}{l}\text { Linear Direct Lensed (100\%) } \\
\text { Dimmed }\end{array}$ & 0.39 & & \\
\hline & & CF Sconce $(30 \%)$ & 0.60 & & & CF Pendant & 0.18 & & \\
\hline Food Prep & $36 \%$ & Linear Direct Lensed (100\%) & 1.20 & 1.20 & 12.9 & Linear Direct Lensed (100\%) & 0.84 & 0.84 & 9.0 \\
\hline Office & $2 \%$ & $\begin{array}{l}\text { Linear Dir/Indir (75\%) } \\
\text { Task (15\%) } \\
\text { Wall Wash }(10 \%)\end{array}$ & 1.20 & 1.20 & 12.9 & Linear Direct Lensed (100\%) & 0.80 & 0.80 & 8.6 \\
\hline $\begin{array}{l}\text { Active } \\
\text { storage }\end{array}$ & $12 \%$ & Linear Direct Lensed (100\%) & 0.80 & 0.80 & 8.6 & Linear Direct Lensed (100\%) & 0.64 & 0.64 & 6.9 \\
\hline $\begin{array}{l}\text { Rest- } \\
\text { rooms }\end{array}$ & $7 \%$ & $\begin{array}{l}\text { CF Down Light (50\%) } \\
\text { Wall Wash }(40 \%) \\
\text { CF Sconce }(10 \%)\end{array}$ & $\begin{array}{l}0.41 \\
0.33\end{array}$ & 0.74 & 8.0 & Linear Direct Lensed (100\%) & 1.10 & 1.10 & 11.8 \\
\hline Lobby & $2 \%$ & $\begin{array}{l}\text { Linear Cove }(20 \%) \\
\text { CF Pendant }(70 \%) \\
\text { CF Down Light }(10 \%)\end{array}$ & 1.32 & 1.32 & 14.2 & Linear Direct Lensed (100\%) & 1.08 & 1.08 & 11.6 \\
\hline $\begin{array}{l}\text { Corridor/ } \\
\text { Transition }\end{array}$ & $1 \%$ & $\begin{array}{l}\text { Linear Direct lensed }(70 \%) \\
\text { CF Down Light }(10 \%)\end{array}$ & 1.36 & 1.36 & 14.6 & CF Downlight (100\%) & 1.08 & 0.50 & 5.4 \\
\hline Other & $4 \%$ & 1-lamp Linear Direct Lensed & 1.20 & 1.20 & 12.9 & 1-lamp Linear Direct Lensed & 1.08 & 1.08 & 11.6 \\
\hline Total & $100 \%$ & & & 1.44 & 15.5 & & & 0.83 & 9.0 \\
\hline & & $\begin{array}{l}\text { The floor area percentage fo } \\
\text { et al. 2008) }\end{array}$ & ace & deriv & $\mathrm{m} \mathrm{a} \mathrm{Na}$ & al Commercial Construction & teristi & atabas & ichman \\
\hline
\end{tabular}


Table 4.6. Lighting Energy Savings from Use of Occupancy Sensors

\begin{tabular}{|c|c|c|c|c|c|c|c|}
\hline \multirow[b]{2}{*}{ Space Type } & \multirow{2}{*}{$\begin{array}{c}\text { Area } \\
(\%)\end{array}$} & \multirow{2}{*}{$\begin{array}{l}\text { Lighting } \\
\text { Systems }\end{array}$} & \multicolumn{2}{|c|}{ Lighting Control Strategy } & \multirow[t]{2}{*}{$\begin{array}{c}\text { Lighting } \\
\text { power } \\
\text { controlled by } \\
\text { occupancy } \\
\text { sensors } \\
(\%)\end{array}$} & \multirow[t]{2}{*}{$\begin{array}{l}\text { Lighting } \\
\text { energy } \\
\text { savings due to } \\
\text { occupancy } \\
\text { sensor } \\
(\%)\end{array}$} & \multirow[b]{2}{*}{ Remarks } \\
\hline & & & Baseline & Advanced & & & \\
\hline Office- private & 2 & ambient & time sweep & $\begin{array}{l}\text { occupancy } \\
\text { sensor }\end{array}$ & 100 & 33 & $(\mathrm{a}, \mathrm{b})$ \\
\hline Active storage & 12 & $\begin{array}{l}\text { standard } \\
\text { design }\end{array}$ & time sweep & $\begin{array}{l}\text { occupancy } \\
\text { sensor }\end{array}$ & 100 & 40 & (c) \\
\hline Restrooms & 7 & $\begin{array}{l}\text { standard } \\
\text { design }\end{array}$ & time sweep & $\begin{array}{l}\text { occupancy } \\
\text { sensor }\end{array}$ & 100 & 26 & (a) \\
\hline \multicolumn{5}{|c|}{ Total lighting energy savings from occupancy sensor control } & & $7.16 \%$ & (d) \\
\hline \multicolumn{8}{|c|}{$\begin{array}{l}\text { (a) Data from VonNeida et al. (2001) } \\
\text { (b) DiLouie (2009) } \\
\text { (c) Data from LRC (2004) } \\
\text { (d) Total energy savings calculated by weighting each lighting type savings by the proportion of the space type in } \\
\text { the building served }\end{array}$} \\
\hline
\end{tabular}

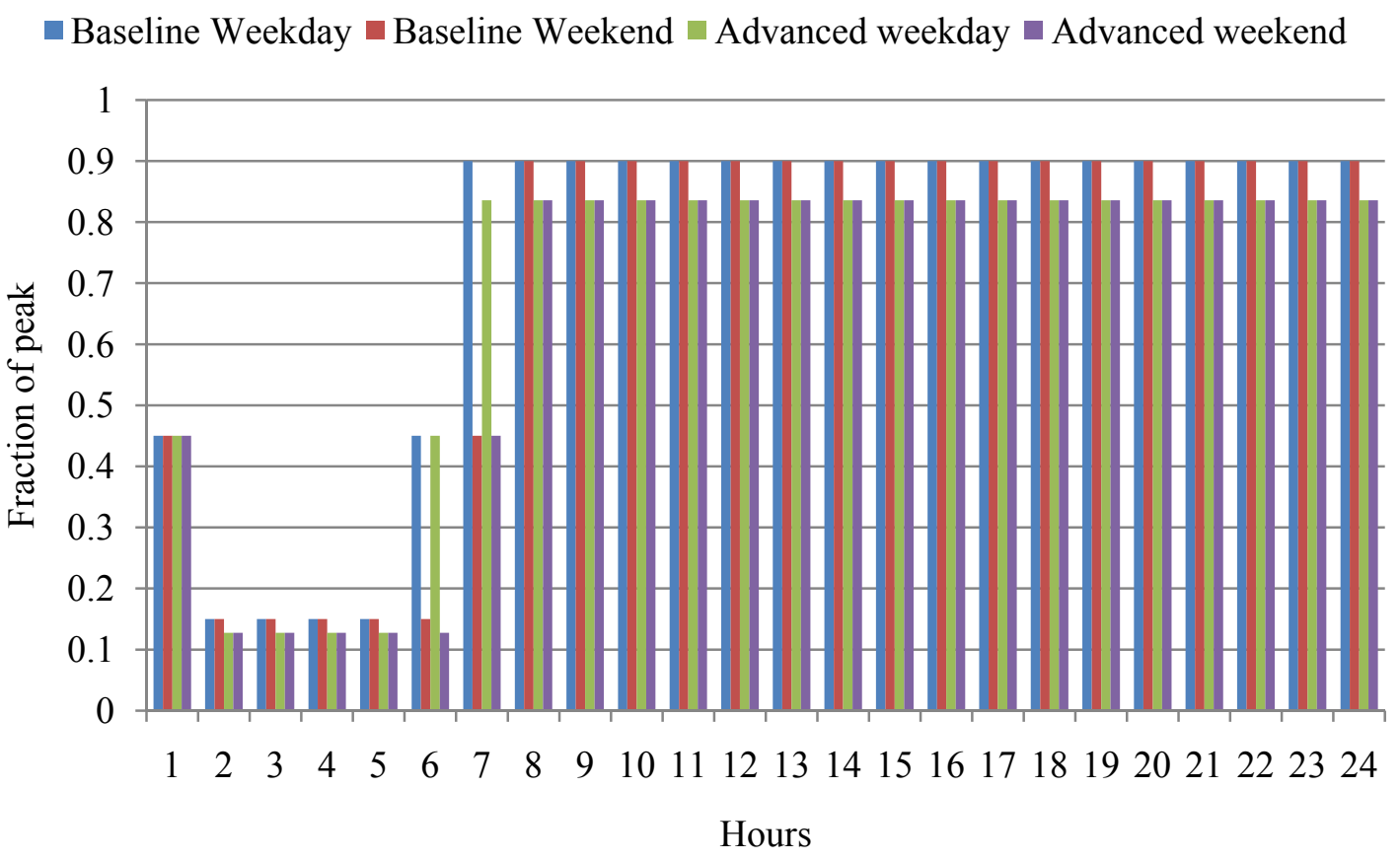

Figure 4.1. Change of Interior Lighting Schedules from Occupancy Sensors 


\subsubsection{Improved Interior Lighting Power Management}

Minimizing egress lighting and locking out all use of egress lighting once a security system identifies a building is unoccupied also will reduce lighting during unoccupied hours. Adoption of occupancy sensors and for some buildings reduced egress lighting and/or security lock-out leads to the interior lighting fraction being reduced from $15 \%$ to $10 \%$ for unoccupied hours for the advanced case (Figure 4.1).

\subsubsection{Daylight Harvesting - Side Lighting}

Daylight harvesting takes advantage of the available daylight to reduce electrical lighting energy consumption while maintaining desired levels of illumination. In the dining zone, daylight access is available through perimeter facades, and high clerestory windows are used to provide side lighting in the space. The daylight modeling for this report does not include the effect of dynamic shading devices, such as interior blinds, or devices that improve the distribution of daylight in the space, such as light shelves and louvers. The placement of windows has been chosen to optimize for daylight availability and quality.

- Strategy: While maintaining the same overall glazing area, the south-facing view windows from the baseline building are broken into upper daylighting windows and lower view windows in the advanced case. High south-facing glazing is used to bring natural light into the dining space. The intent behind separating daylighting windows from view windows is to allow a view window to have interior blinds while leaving the top daylighting window unobstructed. Both the windows use the same glazing type (same U-factor, SHGC, VT) in a given climate location. Thus, in the actual building, the daylighting window and the view window can be one continuous glazing as long as the proper areas are provided and interior blinds are kept clear of the top daylight glazing.

- Daylighting Windows: The total glazing area required to meet the 35 foot candle (375 lux) target in the dining space is $72 \mathrm{ft}^{2}\left(6.7 \mathrm{~m}^{2}\right)$. The top $3 \mathrm{ft}(0.91 \mathrm{~m})$ from the four south-facing view windows is used as daylighting glazing. Each of the four daylight windows measures $6 \mathrm{ft}(1.82 \mathrm{~m})$ by $3 \mathrm{ft}$ $(0.91 \mathrm{~m})$. Figure 4.2 illustrates the view windows in the baseline and Figure 4.3 shows the new daylighting windows and their layout on the south-façade. The glazing for all the windows is chosen according the requirements of public review draft of Addendum BB to Standard 90.1-2007. The low VT requirements imposed by Addendum BB allows glazing to be used on the south face without the aid of exterior window treatments, such as overhangs, to control glare. For Zones 7 and 8, a diffusing film is recommended to control glare because of the higher VT requirements. U-value and SHGC of the daylighting window can be found in Table 4.4.

- Daylight Modeling: An initial study was performed using the Daysim software (Reinhart 2010) program to determine an optimum amount of glazing for Baltimore (zone 4A). Daysim is based upon Radiance (LBNL 2010b), a physically based, backward-raytracing program. Daysim outputs annual illuminance profiles for a grid of user-specified sensors at an hourly time step. The annual illuminance profiles were compared against a 35-foot-candle (375-lux) target exceeding IES's recommendation for dining zones. The glazing area was chosen such that the illuminance target is met for more than $80 \%$ of the time between 8 a.m. and 5 p.m. for the entire year. 


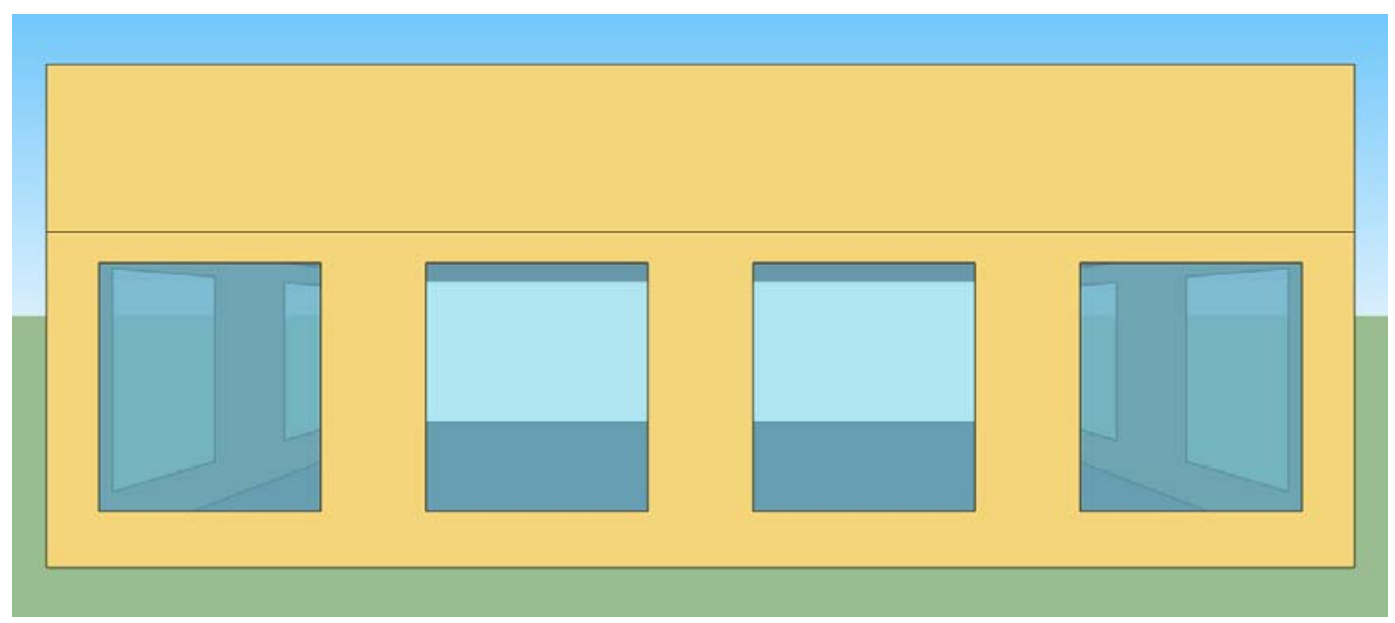

Figure 4.2. The Dining Zone with View Windows in the Baseline Model

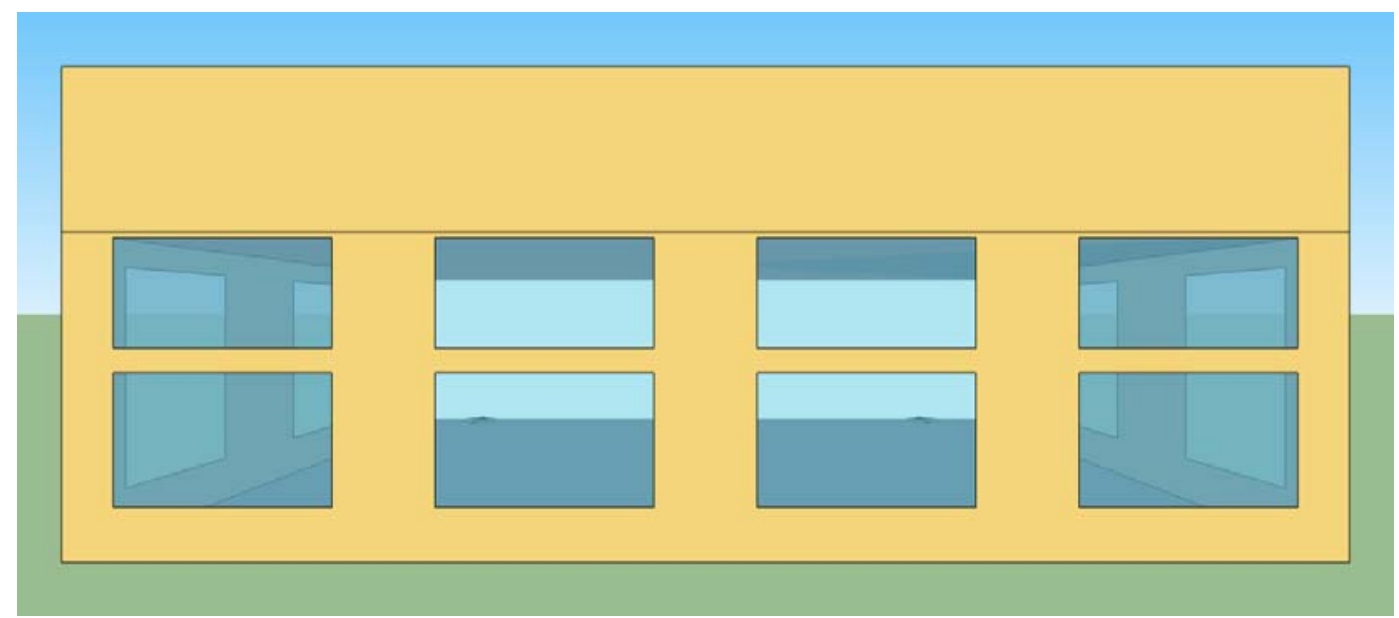

Figure 4.3. The Dining Zone with Separate Daylighting and View Windows in the Advanced Model

- Energy Modeling: The new glazing geometry consisting of separate daylighting and view windows derived from the Daysim study was then ported to the EnergyPlus model to be included in the advanced case energy analysis.

The side-lighting dimming control is modeled in EnergyPlus with the following assumptions:

- Daylit Area: The daylit zone is assumed to be up to a depth of $25 \mathrm{ft}(7.6 \mathrm{~m})$ from the south façade and all the way across the dining zone, resulting in an area of close to $900 \mathrm{ft}^{2}\left(83 \mathrm{~m}^{2}\right)$, which is equal to the dining area in the model.

- Sensor Setup: To account for the savings from daylighting, two sensors are set up in the dining zone. The sensors are located at $12.5 \mathrm{ft}(3.8 \mathrm{~m})$ from the south facade and $8.5 \mathrm{ft}(2.6 \mathrm{~m})$ each from the east and west walls of the dining zone. The sensors are $2.5 \mathrm{ft}(0.76 \mathrm{~m})$ above the floor or approximately at desk height. Each sensor controls $50 \%$ of the lights subject to dimming. The location of these sensors is specific to the simulation in order to account for variance in illuminance distribution across the space, and does not represent actual light sensor placement. Light sensors placed in other locations in an actual QSR can be calibrated to provide correct dimming control. 
- Dimmable Fraction: Spaces such as the office, the lobby, and corridors are considered to be part of the dining zone floor area. These spaces as well as the dining space have some ambient and accent lighting. As a result, the fraction of artificial lights that can be dimmed to account for daylighting is only $33 \%$ of the total input LPD in the model dining zone. Thus, the daylighting control is set to reduce the lighting power level to a $66 \%$ minimum only.

- Illuminance Target: The dimming control system has an illuminance set point of 35 foot candles (375 lux). The dimming controls are continuous. Thus, when daylighting is providing 35 foot candles (375 lux), the total lighting power in the dining zone is reduced to about $66 \%$.

\subsubsection{Exterior Lighting}

\subsubsection{Reduced Exterior Lighting Power Allowances}

The building model assumes exterior lighting on the building façade, at entrances and exits, and for the parking area. Addendum I to Standard 90.1-2007 provides maximum lighting power allowances for each of these areas depending on the Exterior Lighting Zone. From Addendum I, Exterior Lighting Zone 2 was chosen (i.e., "Areas predominantly consisting of residential zoning, neighborhood business districts, light industrial with limited nighttime use and residential mixed use areas"). The lighting power is based on Watts per lineal foot or Watts per square foot depending on the area type.

Addendum I created a Base Site Allowance instead of the 5\% additional allowance of the total exterior connected load. The Base Site Allowance was intended to help small sites as may be found at a QSR. In this advanced case, the Base Site Allowance provides six times higher wattage allowance than the 5\% additional allowance would have provided. As shown in Table 4.7, the total connected exterior lighting load is reduced from baseline $4333 \mathrm{~W}$ to $2687 \mathrm{~W}$.

\subsubsection{Exterior Lighting Control}

Parking lot lighting is assumed to have bi-level switching ballasts that will reduce its power between 12 p.m. and 6 a.m. Façade lighting also is controlled to turn off between midnight and 6 a.m. Therefore, in the advanced models, exterior lighting is assumed to be controlled by a combination of photocells and timers. Timers set the exterior lighting power at $50 \%$ of the design level when no occupants are present between 12 p.m. and 6 a.m. The photocell plays the role of turning off the exterior lights during daylight hours even if the scheduled lighting power is not zero. In contrast, for the base case, exterior lights are fully energized whenever it is dark outside. 
Table 4.7. Exterior Lighting Power Reduction

\begin{tabular}{|c|c|c|c|c|}
\hline \multirow[b]{2}{*}{ Items } & \multicolumn{2}{|c|}{ Baseline } & \multicolumn{2}{|c|}{ Advanced } \\
\hline & (IP units) & (SI units) & (IP units) & (SI units) \\
\hline \multicolumn{5}{|l|}{ Parking } \\
\hline parking area, $\mathrm{ft}^{2}\left(\mathrm{~m}^{2}\right)^{(\mathrm{a})}$ & 19,553 & 1,817 & 19,553 & 1,817 \\
\hline lighting power allowance for parking $\mathrm{W} / \mathrm{ft}^{2}\left(\mathrm{~W} / \mathrm{m}^{2}\right)$ & 0.15 & 2 & 0.06 & 1 \\
\hline total lighting power for parking, $\mathrm{W}(\mathrm{W})$ & 2,933 & 2,933 & 1,173 & 1,173 \\
\hline \multicolumn{5}{|l|}{ Walkways } \\
\hline walkway area, $\mathrm{ft}^{2}\left(\mathrm{~m}^{2}\right)^{(\mathrm{a})}$ & 1108 & 103 & 1108 & 103 \\
\hline lighting power allowance for walkway area $\mathrm{W} / \mathrm{ft}^{2}\left(\mathrm{~W} / \mathrm{m}^{2}\right)$ & 0.2 & 2 & 0.14 & 2 \\
\hline total lighting power for walkway area W (W) & 222 & 222 & 155 & 155 \\
\hline \multicolumn{5}{|l|}{ Building entrance and exits ${ }^{(\mathrm{a}, \mathrm{b})}$} \\
\hline \multicolumn{5}{|l|}{ main entries } \\
\hline linear foot of door width for main entries, $\mathrm{ft}(\mathrm{m})$ & 6 & 2 & 6 & 2 \\
\hline lighting power allowance for main entries $\mathrm{W} / \mathrm{ft}(\mathrm{W} / \mathrm{m})$ & 30 & 98 & 20 & 66 \\
\hline canopy over entry, $\mathrm{ft}^{2}\left(\mathrm{~m}^{2}\right)$ & 30 & 3 & 30 & 3 \\
\hline lighting power allowance for canopy $\mathrm{W} / \mathrm{ft}^{2}\left(\mathrm{~W} / \mathrm{m}^{2}\right)$ & 1.25 & 13 & 0.25 & 3 \\
\hline total lighting power for main entries W (W) & 218 & 218 & 128 & 128 \\
\hline \multicolumn{5}{|l|}{ other doors } \\
\hline linear foot of door width for other doors, $\mathrm{ft}(\mathrm{m})$ & 6 & 2 & 6 & 2 \\
\hline lighting power allowance for other doors W/ft (W/m) & 20 & 66 & 20 & 66 \\
\hline canopy over entry $\mathrm{ft}^{2}\left(\mathrm{~m}^{2}\right)$ & 42 & 4 & 42 & 4 \\
\hline lighting power allowance for canopy $\mathrm{W} / \mathrm{ft}^{2}\left(\mathrm{~W} / \mathrm{m}^{2}\right)$ & 1.25 & 14 & 0.25 & 14 \\
\hline total lighting power for other doors $\mathrm{W}(\mathrm{W})$ & 173 & 173 & 131 & 131 \\
\hline total lighting power for building entrance and exits W (W) & 391 & 391 & 259 & 259 \\
\hline \multicolumn{5}{|l|}{ Building facades } \\
\hline façade area lighted $\mathrm{ft}^{2}\left(\mathrm{~m}^{2}\right)$ & 1000 & 93 & 1000 & 93 \\
\hline lighting power allowance for building facades $\mathrm{W} / \mathrm{ft}^{2}\left(\mathrm{~W} / \mathrm{m}^{2}\right)$ & 0.2 & 2 & 0.1 & 1 \\
\hline total lighting power for building facades $\mathrm{W}(\mathrm{W})$ & 200 & 200 & 100 & 100 \\
\hline $\begin{array}{l}\text { Sum of lighting power for parking, building entrance and facades } \mathrm{W} \\
\text { (W) }\end{array}$ & 3,746 & 3,746 & 1,687 & 1,687 \\
\hline Zone 3 base site allowance W (W) & 187 & 187 & 600 & 600 \\
\hline \multicolumn{5}{|l|}{ Non-Tradable Surface allowance } \\
\hline Drive-up windows at fast food restaurants $\mathrm{W}(\mathrm{W})$ & 400 & 400 & 400 & 400 \\
\hline Total exterior lighting power $\mathrm{W}(\mathrm{W})$ & 4,333 & 4,333 & 2,687 & 2,687 \\
\hline \multicolumn{5}{|c|}{$\begin{array}{l}\text { (a) Parking \& Drive area, Walkways, and Building entrance \& exits are from Standard 90.1-2004 (baseline) and } \\
\text { Zone } 2 \text { of 90.1-2007 addenda I (advanced model), 4-zone LPD development } \\
\text { (b) All doors have a width of } 3 \mathrm{ft}(0.29 \mathrm{~m}) .\end{array}$} \\
\hline
\end{tabular}




\subsection{Commercial Kitchen Appliances}

Various types of EEMs were incorporated that deal directly or indirectly with the energy use in a commercial kitchen. The purpose of the EEMs is to reduce the energy consumption of the appliances and reduce their heat contributions to the space. The measures discussed in this section include using higher efficiency appliances on the main cook line and upgrading the unhooded appliances. Reduction of kitchen hood exhaust flow and its control will be discussed in Section 4.4.1.

\subsubsection{Estimating Cooking Energy Use}

For the baseline building, the annual EUI for the cooking equipment was estimated at $423 \mathrm{kBtu} / \mathrm{ft}^{2}$ $\left(1334 \mathrm{kWh} / \mathrm{m}^{2}\right)$ for the gas appliances on the main cook line and $171 \mathrm{kBtu} / \mathrm{ft}^{2}\left(539 \mathrm{kWh} / \mathrm{m}^{2}\right)$ for the unhooded electrical appliances. After all of the equipment substitutions and changes discussed in this section were implemented, the annual EUI for the main cook line was reduced to an annual energy usage of $246 \mathrm{kBtu} / \mathrm{ft}^{2}\left(770 \mathrm{kWh} / \mathrm{m}^{2}\right)$, and for the unhooded equipment, the annual energy consumption was reduced to $131 \mathrm{kBtu} / \mathrm{ft}^{2}\left(413 \mathrm{kWh} / \mathrm{m}^{2}\right)$.

\subsubsection{Cooking Appliances}

For the cooking appliances, it was decided that the best-in-class ENERGY STAR qualified appliances and California utility rebate qualified appliances would substitutes for the ones used in the baseline (EnergyStar 2010; FSTC 2010b). Specifically, the two 40-in wide (102-cm), gas-fired grills (which were single-sided) were replaced with two double-sided grills. The four deep-fat fryers were replaced with a total of three high efficiency fryers as shown in Table 4.8. The performance data and production capacities for the double-sided grills are shown in Table 4.9 and those for the fryers are shown in Table 4.10 .

Table 4.8. Efficient Hooded Equipment

\begin{tabular}{cccccc}
\hline & & & \multicolumn{3}{c}{ Nameplate } \\
Quantity & Type & Fuel Source & $\begin{array}{c}\text { Width, } \\
\text { in. }(\mathrm{cm})\end{array}$ & $\begin{array}{c}\text { Input, } \\
\mathrm{kBtu} / \mathrm{h}(\mathrm{kW})\end{array}$ & $\mathrm{F}_{\mathrm{u}, \text { idle }}$ \\
\hline 1 & Double-sided griddle, model A & Gas and Electric & $28.25(28)$ & $96(28)$ & $14 \%$ \\
1 & Double-sided griddle, model B & Gas and Electric & $40.25(102)$ & $143(42)$ & $11 \%$ \\
1 & Fryers, model A & Gas & $24.25(62)$ & $120(35)$ & $4 \%$ \\
2 & Fryers, model B & Gas & $15.75(40)$ & $120(35)$ & $3 \%$ \\
Total & & & & $599(175)$ & \\
\hline
\end{tabular}

Table 4.9. Efficient Griddle Performance and Production Capacity Information

\begin{tabular}{lcccc}
\hline \multirow{2}{*}{ Appliance State } & \multicolumn{2}{c}{ Griddle, Model A } & \multicolumn{2}{c}{ Griddle, Model B } \\
\cline { 2 - 5 } & $\begin{array}{c}\text { Energy Input } \\
\text { (\% of Nameplate) }\end{array}$ & $\begin{array}{c}\text { Production Capacity, } \\
\text { lb/h }(\mathrm{kg} / \mathrm{h})\end{array}$ & $\begin{array}{c}\text { Energy Input } \\
\text { (\% of Nameplate) }\end{array}$ & $\begin{array}{c}\text { Production Capacity, } \\
\mathrm{lb} / \mathrm{h}(\mathrm{kg} / \mathrm{h})\end{array}$ \\
\hline Idle & $14 \%$ & $0(0)$ & $11 \%$ & $0(0)$ \\
Light & $28 \%$ & $18.4(8.3)$ & $27 \%$ & $19.6(8.9)$ \\
Medium & $42 \%$ & $38.3(17.4)$ & $38 \%$ & $45.5(20.6)$ \\
Heavy & $57 \%$ & $58.1(26.5)$ & $48 \%$ & $71.4(32.4)$ \\
\hline
\end{tabular}


Table 4.10. Efficient Fryer Performance and Production Capacity Information

\begin{tabular}{lcccc}
\hline \multirow{2}{*}{ Appliance State } & \multicolumn{2}{c}{ Fryer, Model A } & \multicolumn{2}{c}{ Fryer, Model B } \\
\cline { 2 - 5 } & $\begin{array}{c}\text { Energy Input } \\
\text { \% of Nameplate) }\end{array}$ & $\begin{array}{c}\text { Production Capacity, } \\
\mathrm{lb} / \mathrm{h}(\mathrm{kg} / \mathrm{h})\end{array}$ & $\begin{array}{c}\text { Energy Input } \\
\text { \% of Nameplate) }\end{array}$ & $\begin{array}{c}\text { Production Capacity, } \\
\mathrm{lb} / \mathrm{h}(\mathrm{kg} / \mathrm{h})\end{array}$ \\
\hline Idle & $4 \%$ & $0(0)$ & $3 \%$ & $0(0)$ \\
Light & $16 \%$ & $18.6(8.4)$ & $16 \%$ & $18.4(8.3)$ \\
Medium & $47 \%$ & $67.1(30.4)$ & $31 \%$ & $41.0(18.6)$ \\
Heavy & $91 \%$ & $134.2(60.9)$ & $59 \%$ & $81.9(37.1)$ \\
\hline
\end{tabular}

Because the cooking equipment is being switched from the baseline to the efficiency cases, it is important to keep the amount of food cooked the same in both cases. The production capacity for the baseline case was determined using the following formula in conjunction with the appliance usage factors from Table 3.14:

$$
P C_{T O T, d}=\sum_{i=1}^{n}\left(A_{U F} \cdot P C_{i, d}\right)
$$

$P C_{T O T, d}$ is the production capacity for duty-level d, $A_{U F}$ is the usage factor (number of appliances) for the appliance at duty-level $\mathrm{d}$, and $P C_{i, d}$ is the production capacity at duty level $\mathrm{d}$. Next, the appliance usage factors were adjusted so the efficient equipment achieved the same overall production capacity as the baseline equipment. The final usage factors for the efficient appliances are shown in Table 4.11.

Table 4.11. Efficient Hooded Appliance Usage Factors

\begin{tabular}{ccccccccc}
\hline$\%$ & \multicolumn{4}{c}{ Griddle Duty/Quantity } & \multicolumn{4}{c}{ Fryer Duty/Quantity } \\
\cline { 2 - 8 } Occupancy & Idle & Light & Medium & Heavy & Idle & Light & Medium & Heavy \\
\hline $0-29 \%$ & 2 & 0 & 0 & 0 & 3 & 0 & 0 & 0 \\
$30-39 \%$ & 1.5 & 0.5 & 0 & 0 & 1.9 & 1.1 & 0 & 0 \\
$40-59 \%$ & 1.5 & 0.4 & 0.1 & 0 & 1.5 & 1 & 0.5 & 0 \\
$60-100 \%$ & 0.5 & 1.3 & 0.2 & 0 & 0.8 & 1.2 & 1 & 0 \\
\hline
\end{tabular}

The unhooded appliances that operate when the restaurant is open for business are shown in Table 4.12, and the equipment used only when breakfast is being served is presented in Table 4.13.

In Table 4.12, the airpot coffee brewer replaced the coffee brewer and warmer. With the airpot coffee brewer, the coffee pots do not need to be kept hot after the coffee is brewed. Making this change was beneficial in two ways: it resulted in elimination of the coffee warmers, and the airpot coffee brewer is, on average, more energy efficient than the baseline coffee brewer. The generic holding cabinets from the baseline case have been replaced with holding cabinets with solid doors. This change resulted in reductions of the operating power required and the latent and sensible heat gains to the kitchen space. 
Table 4.12. Unhooded Equipment on During Open Restaurant Hours in Advanced Model

\begin{tabular}{clcccccc}
\hline Quantity & \multicolumn{1}{c}{ Type } & $\begin{array}{c}\text { Nameplate } \\
\text { Input, each } \\
(\mathrm{kW})\end{array}$ & $\mathrm{F}_{\mathrm{u}, \mathrm{idle}}$ & $\mathrm{F}_{\mathrm{u}, \mathrm{cook}}$ & $\begin{array}{c}\mathrm{F}_{\mathrm{r}} \\
\text { (sensible } \\
\text { radiant) }\end{array}$ & $\begin{array}{c}\mathrm{F}_{\mathrm{s}} \\
\text { (sensible } \\
\text { convective) }\end{array}$ & $\begin{array}{c}\mathrm{F}_{\mathrm{L}} \\
\text { (latent) }\end{array}$ \\
\hline 1 & Airpot Coffee Brewer & 1.75 & 0.09 & -- & 0.25 & 0.75 & 0 \\
1 & Juice Dispenser & 0.6 & 0.4 & -- & 0.25 & 0.75 & 0 \\
1 & Milk Shake Dispenser & 3.9 & 0.15 & -- & 0.25 & 0.75 & 0 \\
1 & Ice Cream Dispenser & 3.9 & 0.15 & -- & 0.25 & 0.75 & 0 \\
1 & Heat Lamp & 2.9 & 1 & -- & 0.5 & 0.5 & 0 \\
3 & Holding Cabinets & 1.5 & 0.05 & -- & 0.27 & 0.54 & 0.18 \\
2 & Microwave & 6.8 & & 0.25 & 0.25 & 0.75 & 0 \\
2 & Conveyor Toaster & 3.8 & 0.47 & -- & 0.11 & 0.89 & 0 \\
\hline \multicolumn{7}{l}{ Data from proprietary QSR studies and Smith and Fisher (2001) }
\end{tabular}

In Table 4.13, the generic half-size convection oven was replaced with a high efficiency oven, which has a higher nameplate input rating but has a significantly lower usage factor resulting in a lower overall energy consumption during the day.

Table 4.13. Advanced Equipment Operating During Breakfast Hours

\begin{tabular}{|c|c|c|c|c|c|c|c|}
\hline Quantity & Type & $\begin{array}{c}\text { Nameplate } \\
\text { Input, each } \\
(\mathrm{kW})\end{array}$ & $\mathrm{F}_{\mathrm{u}, \mathrm{idle}}$ & $\mathrm{F}_{\mathrm{u}, \mathrm{cook}}$ & $\begin{array}{c}\mathrm{F}_{\mathrm{r}} \\
\text { (sensible } \\
\text { radiant) } \\
\end{array}$ & $\begin{array}{c}\mathrm{F}_{\mathrm{s}} \\
\text { (sensible } \\
\text { convective) }\end{array}$ & $\begin{array}{c}\mathrm{F}_{\mathrm{L}} \\
\text { (latent) }\end{array}$ \\
\hline 2 & Half-size convection oven & 12 & 0.05 & -- & 0.17 & 0.83 & 0 \\
\hline Data fron & proprietary QSR study & & & & & & \\
\hline
\end{tabular}

\subsubsection{Refrigeration Equipment}

Energy efficient refrigeration appliances used 24 hours per day are shown in Table 4.14. Several energy efficiency measures were identified for the walk-in cooler and freezer. The insulation was expanded from the industry-standard 3.5-in. (88-mm) thick urethane panels to 5-in. (125-mm) thick urethane panels. Other measures include electronically-commutated evaporator fan motors, compact fluorescent lighting, strip curtains on the outer doors, advanced refrigeration systems with electronicallycontrolled expansion valves and demand-based defrosting, and a desuperheater to recover waste refrigerant heat. Each of the measures contributes to lowering energy use of the walk-in refrigeration system. The simulation inputs are $1.5 \mathrm{kBtu} / \mathrm{h}(440 \mathrm{~W})$ for the advanced walk-in cooler and $3.5 \mathrm{kBtu} / \mathrm{h}$ $(1020 \mathrm{~W})$ for the advanced walk-in freezer. 
Table 4.14. Efficient Refrigeration Equipment Operating 24 Hours per Day

\begin{tabular}{|c|c|c|c|c|c|c|c|}
\hline Quantity & Type & $\begin{array}{c}\text { Nameplate } \\
\text { Input, each } \\
(\mathrm{kW})\end{array}$ & $F_{u, \text { idle }}$ & $\mathrm{F}_{\mathrm{u}, \mathrm{cook}}$ & $\begin{array}{c}\mathrm{F}_{\mathrm{r}} \text { (sensible } \\
\text { radiant) }\end{array}$ & $\begin{array}{l}\mathrm{F}_{\mathrm{S}} \text { (sensible } \\
\text { convective) }\end{array}$ & $\begin{array}{c}\mathrm{F}_{\mathrm{L}} \\
\text { (latent) }\end{array}$ \\
\hline 1 & $\begin{array}{l}\text { Reach-In Refrigerator } \\
\text { (2-door) }\end{array}$ & 1 & 0.15 & -- & 0.25 & 0.75 & 0 \\
\hline 1 & $\begin{array}{l}\text { Reach-in Freezer } \\
\text { (1-door) }\end{array}$ & 1 & 0.25 & -- & 0.25 & 0.75 & 0 \\
\hline 2 & $\begin{array}{l}\text { Undercounter } \\
\text { Refrigerator }\end{array}$ & 0.7 & 0.1 & -- & 0.25 & 0.75 & 0 \\
\hline 1 & Undercounter Freezer & 1.3 & 0.2 & -- & 0.25 & 0.75 & 0 \\
\hline 2 & Refrigerated Prep Table & 0.5 & 0.25 & -- & 0.67 & 0.33 & 0 \\
\hline 2 & $\begin{array}{l}\text { Ice Machine, } 1000 \\
\text { lb/day }\end{array}$ & 0.6 & 0.5 & -- & 0.25 & 0.75 & 0 \\
\hline 2 & Remote Condenser & 2.4 & 0.5 & -- & 0 & 0 & 0 \\
\hline
\end{tabular}

Table 4.15. Energy-Efficient Walk-In Refrigeration Systems

\begin{tabular}{cccccccc}
\hline & $\begin{array}{c}\text { Area, } \\
\mathrm{ft}^{2}\end{array}$ & $\begin{array}{c}\text { Length, } \\
\mathrm{ft}\end{array}$ & $\begin{array}{c}\text { Cooling } \\
\text { capacity } \\
\mathrm{kBtu} / \mathrm{h}\end{array}$ & $\begin{array}{c}\text { Case } \\
\text { Temperature, } \\
\mathrm{F}\end{array}$ & $\begin{array}{c}\text { Condenser } \\
\text { Location }\end{array}$ & $\begin{array}{c}\text { Average Energy } \\
\text { Consumption } \\
\text { Rate, } \mathrm{W}\end{array}$ & $\begin{array}{c}\text { Daily Energy } \\
\text { Consumption, } \\
\mathrm{kWh}\end{array}$ \\
\hline Walk-in cooler & 100 & 10 & 7.7 & 35 & outdoor & 440 & 10.5 \\
Walk-in freezer & 80 & 8 & 5.7 & -10 & outdoor & 1,020 & 24.5 \\
\hline
\end{tabular}

\subsection{Building HVAC Systems}

The baseline HVAC systems presented in Section 3.4 use two constant air volume packaged rooftop units, each serving one of kitchen and dining zones. The EEMs for HVAC systems include reduced exhaust flow using efficient hoods, advanced control for the kitchen hoods, dedicated outdoor air systems, high-efficiency cooling and heating systems, and heat recovery with coil runaround loop. They are discussed in the following sections.

\subsubsection{Kitchen Exhaust Hood}

The exhaust hoods (i.e., two proximity hoods) selected for the advanced model are based on the efficient equipment selected in Table 4.8. Table 4.16 shows the overall length, depth, and airflows of the hoods. The airflow per foot is based on the requirements of the International Mechanical Code (ICC 2009). The total exhaust airflow for the hoods is reduced from $4600 \mathrm{cfm}\left(2.17 \mathrm{~m}^{3} / \mathrm{s}\right)$ in the baseline to about $1830 \mathrm{cfm}\left(0.86 \mathrm{~m}^{3} / \mathrm{s}\right)$ in the low-energy case.

Not only can the exhaust fan flow rate be reduced in the advance model, but a demand-controlled exhaust fan flow rate based on hooded appliance use also can improve the energy efficiency of the advanced QSR building. Based on the operating schedules for the hooded cooking appliances, a fractional schedule of the kitchen exhaust flow rate was developed as shown in Figure 4.4. 
Table 4.16. Advanced Exhaust Hood Specifications

\begin{tabular}{cccccc}
\hline Hood & Style & $\begin{array}{c}\text { Length } \\
\text { in. }(\mathrm{m})\end{array}$ & $\begin{array}{c}\text { Depth } \\
\text { in. }(\mathrm{m})\end{array}$ & $\begin{array}{c}\text { Airflow } \\
\mathrm{cfm} / \mathrm{ft}\left(\mathrm{m}^{3} / \mathrm{s}-\mathrm{m}\right)\end{array}$ & $\begin{array}{c}\text { Airflow } \\
\mathrm{cfm}\left(\mathrm{m}^{3} / \mathrm{s}\right)\end{array}$ \\
\hline Griddle & Proximity & $72.5(1.84)$ & $32(0.81)$ & $180(0.279)$ & $1,088(0.51)$ \\
Fryer & Proximity & $59.75(1.52)$ & $32(0.81)$ & $150(0.232)$ & $747(0.35)$ \\
\hline Total & \multicolumn{4}{c}{ Weekday } & vWeekend
\end{tabular}

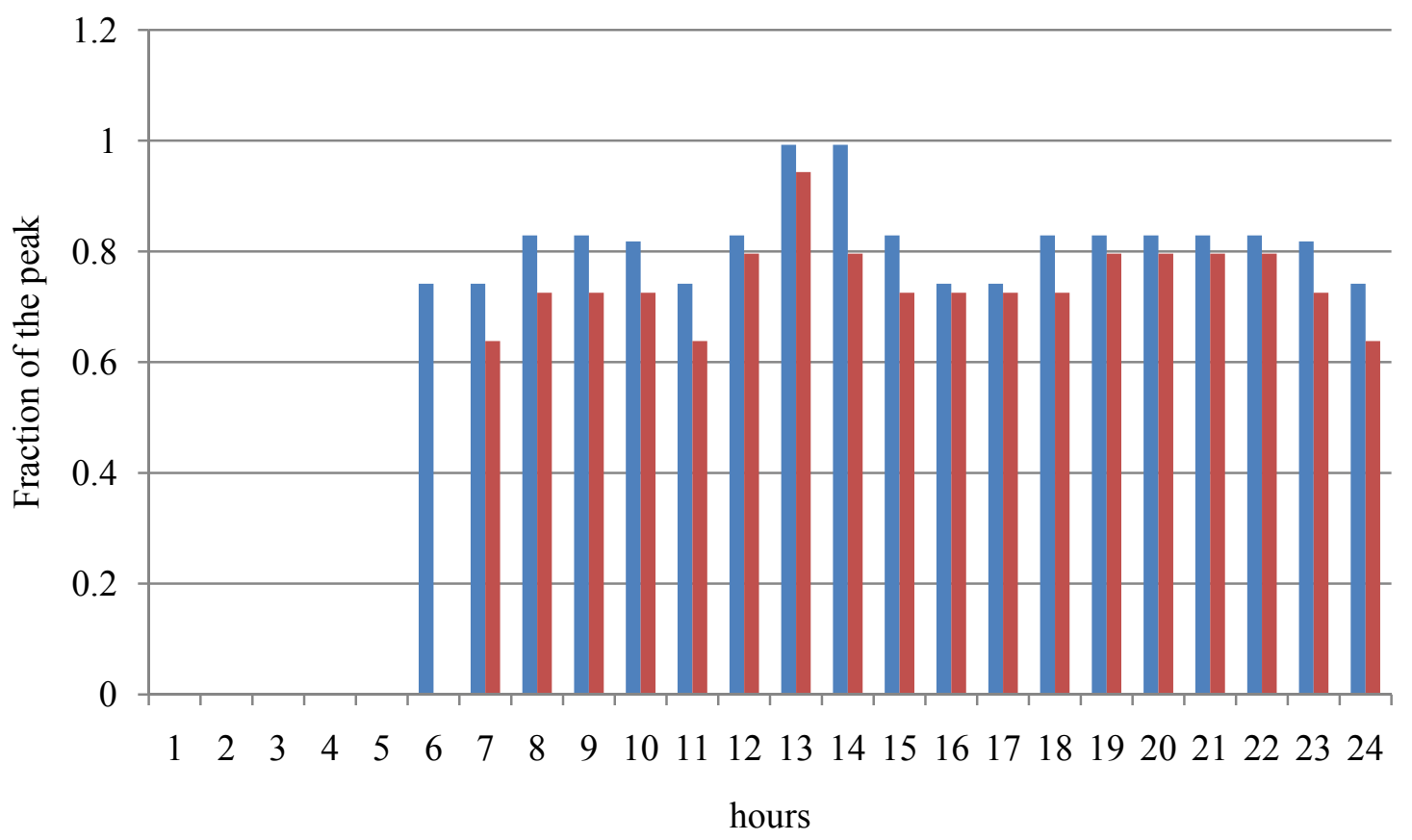

Figure 4.4. Fractional Schedule for the Kitchen Hood Exhaust Rate

\subsubsection{HVAC System Configuration}

The energy-efficient HVAC system configuration retains the design features of having separate rooftop units for the kitchen and dining zones. It also uses a DOAS, which can handle up to $100 \%$ of the latent and sensible loads associated with the outdoor air. As shown in Figure 4.5, the conditioned outdoor air from the DOAS is supplied directly to the RTUs serving the kitchen and dining zones. The introduction of outdoor air for the whole building through DOAS unit allows air-to-air heat recovery from kitchen exhaust to be a reasonable and cost-effective EEM as discussed in Section 4.4.3.

Because the exhaust airflows through the hoods have been reduced from $4600 \mathrm{cfm}\left(2.17 \mathrm{~m}^{3} / \mathrm{s}\right)$ to $1830 \mathrm{cfm}\left(0.86 \mathrm{~m}^{3} / \mathrm{s}\right)$, the total amount of air flowing out of the building, through the kitchen hoods, air exfiltration, and bathroom exhaust fans, was reduced from the baseline of $5200 \mathrm{cfm}\left(2.45 \mathrm{~m}^{3} / \mathrm{s}\right)$ to 2430 $\operatorname{cfm}\left(1.15 \mathrm{~m}^{3} / \mathrm{s}\right)$. If the $2430 \mathrm{cfm}\left(1.15 \mathrm{~m}^{3} / \mathrm{s}\right)$ outdoor air from the DOAS is split to the dining and kitchen with the same ratio of 2:3 as that used in the baseline, the outdoor airflow to the dining would have been around $970 \mathrm{cfm}$. The calculated minimum outdoor air in the dining zone required by the Standard 62.12004 is $880 \mathrm{cfm}\left(0.42 \mathrm{~m}^{3} / \mathrm{s}\right)$. Because the $970 \mathrm{cfm}\left(0.46 \mathrm{~m}^{3} / \mathrm{s}\right)$ airflow is close to the airflow required by 
Standard $62.1,880 \mathrm{cfm}\left(0.42 \mathrm{~m}^{3} / \mathrm{s}\right)$ was used as the outdoor air amount supplied to dining zone, and the whole building air balance is shown in Table 4.17.

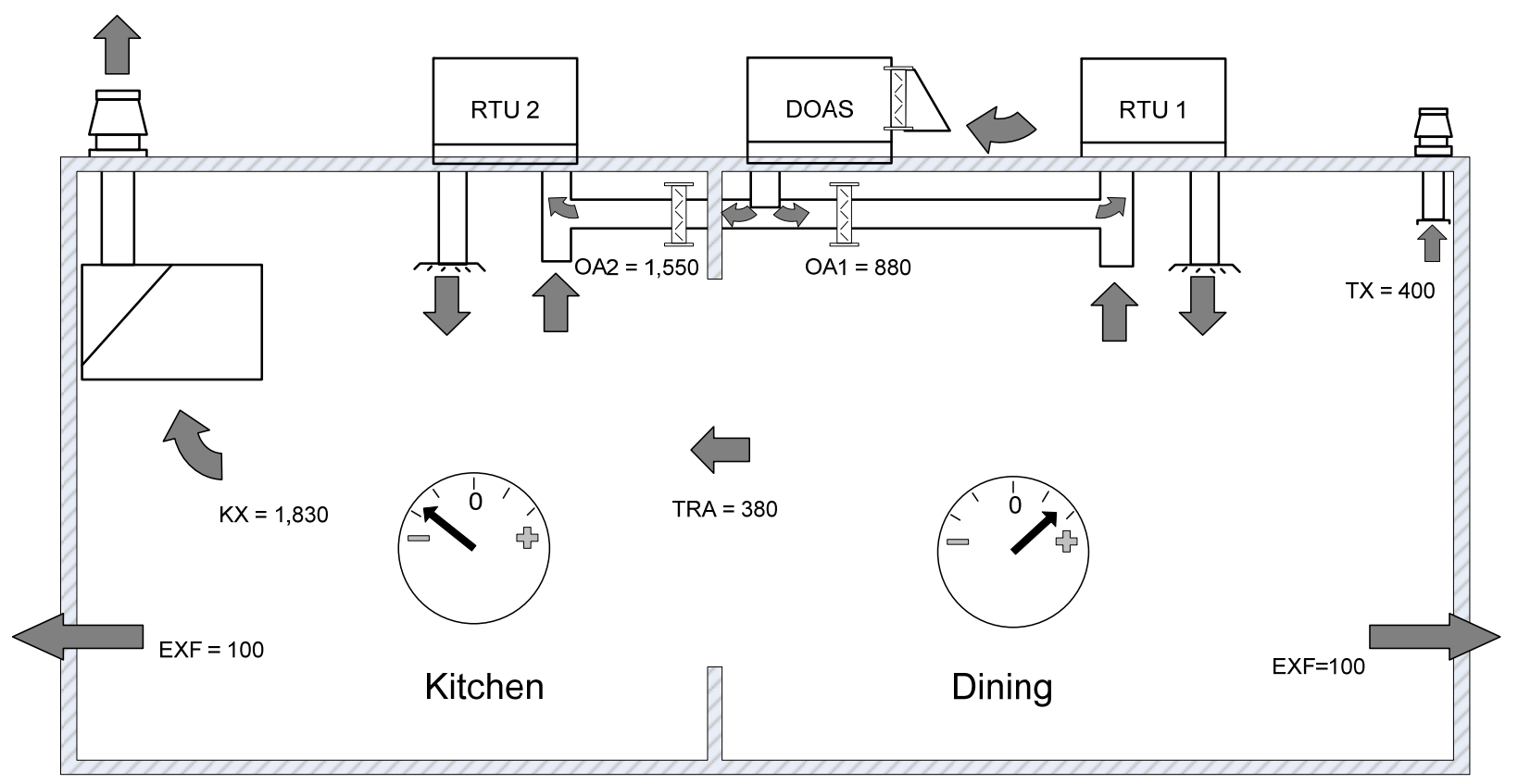

Figure 4.5. Efficient HVAC System Configuration

Table 4.17. Air Balance for Efficient HVAC Configuration

\begin{tabular}{llcc}
\hline & & Airflow $(\mathrm{cfm})$ & Airflow $\left(\mathrm{m}^{3} / \mathrm{s}\right)$ \\
\hline Exhaust Air & Kitchen Exhaust Hoods & 1830 & 0.86 \\
& Bathroom & 400 & 0.19 \\
& Kitchen Exfiltration & 100 & 0.05 \\
& Dining Exfiltration & 100 & 0.05 \\
& Total & 2430 & 1.15 \\
\hline Outdoor Intake Air & Dining (thru DOAS) & 2080 & 0.98 \\
& Kitchen (thru DOAS) & 1550 & 0.73 \\
& Total & 2430 & 1.15 \\
\hline
\end{tabular}

\subsubsection{Heat Recovery from Exhaust Flow with a Runaround Loop}

QSRs exhaust large amounts of heat generated by cooking appliances to the outdoor environment through their exhaust hoods. Air-to-air heat recovery through a runaround loop coil is an EEM to recover the waste heat to the outdoor air intake. EnergyPlus requires sensible effectiveness of the heat exchanger as well as the power inputs of the accessory equipment in the heat recovery systems.

According to the ASHRAE Handbook Heating, Ventilating, and Air-Conditioning Systems and Equipment (ASHRAE 2008), the sensible effectiveness of runaround loop heat recovery is between $55 \%$ and $65 \%$ for balanced flow. The runaround loop system does not recover latent heat. Considering the unbalanced flow of the heat recovery air supply $\left(2430 \mathrm{cfm}\left[1.15 \mathrm{~m}^{3} / \mathrm{s}\right]\right)$ and exhaust $(1170 \mathrm{cfm}$ to $1830 \mathrm{cfm}$ [ 0.55 to $\left.0.86 \mathrm{~m}^{3} / \mathrm{s}\right]$; the variation is due to the demand control ventilation) in the advanced HVAC configuration, we assumed a sensible effectiveness of $45 \%$ to be conservative in terms of energy 
saving estimate. This assumption is based on the authors' practical design experiences. The increased pressure drop associated with runaround loop coils is estimated to be 1 in. w.c. ( $250 \mathrm{~Pa}$ ) for both the supply and exhaust sides. This pressure drop is added to the supply fan pressure drop input in the EnergyPlus model. The pump energy required for circulating the water or antifreeze solution in the loop is assumed to be $40 \mathrm{~W}$, which is input as accessory equipment power. Because of the energy penalty resulting from the increased fan pressure and additional pump, the runaround coil heat recovery in QSRs is only beneficial in some cold climate zones represented by Chicago, Minneapolis, Helena, Duluth, and Fairbanks (see Table 4.18).

Table 4.18. Application of Air-to-air Heat Recovery

\begin{tabular}{ccc}
\hline Climate Zone & Representative City & Air-to-air Heat Recovery \\
\hline 1A & Miami & No \\
2A & Houston & No \\
2B & Phoenix & No \\
3A & Atlanta & No \\
3B-CA & Los Angeles & No \\
3B-other & Las Vegas & No \\
3C & San Francisco & No \\
4A & Baltimore & No \\
4B & Albuquerque & No \\
4C & Seattle & No \\
5A & Chicago & Yes \\
5B & Denver & No \\
6A & Minneapolis & Yes \\
6B & Helena & Yes \\
7 & Duluth & Yes \\
8 & Fairbanks & Yes \\
\hline
\end{tabular}

\subsubsection{HVAC System Efficiency}

The advanced models cover the premium HVAC equipment for DX coils and fan motors. The premium air conditioner is selected from the updated product engineering catalog databases maintained by California Energy Commission (CEC 2010). In the selection process, we made sure that the selected efficiency represents products from at least two manufacturers. Table 4.19 lists the selected higher cooling efficiency in terms of SEER or EER. Because COP is required input in EnergyPlus, the corresponding COP values also are presented in this Table 4.19, and they are calculated using the method described in Section 3.4.5. The mechanical efficiency of fans in the advanced model is improved from $55 \%$ to $65 \%$. The efficiency of the gas furnace in the packaged units is not improved in this work. Packaged units with higher gas furnace efficiency may be explored in future work. 
Table 4.19. Higher Efficiency for Packaged Unitary Air Conditioners for the Advanced Case

\begin{tabular}{lcc}
\hline \multicolumn{1}{c}{ Size Category } & $\begin{array}{c}\text { Efficiency } \\
\text { (SEER/EER) }\end{array}$ & $\begin{array}{c}\text { EnergyPlus } \\
\text { Input (COP) }\end{array}$ \\
\hline$<65,000 \mathrm{Btu} / \mathrm{h}(<19 \mathrm{~kW})^{\left({ }^{(a)}\right.}$ & 15 SEER & 4.31 \\
$65,000 \sim 135,000 \mathrm{Btu} / \mathrm{h}(19 \sim 40 \mathrm{~kW})^{(\text {a) }}$ & 11.5 EER & 3.97 \\
$135,000 \sim 240,000 \mathrm{Btu} / \mathrm{h}(40 \sim 70 \mathrm{~kW})^{(\text {a) }}$ & $11.3 \mathrm{EER}$ & 3.90 \\
$240,000 \sim 300,000 \mathrm{Btu} / \mathrm{h}(70 \sim 88 \mathrm{~kW})$ & $10.5 \mathrm{EER}$ & 3.63 \\
$300,000 \sim 760,000 \mathrm{Btu} / \mathrm{h}(88 \sim 223 \mathrm{~kW})$ & $10.2 \mathrm{EER}$ & 3.53 \\
$\geq 760,000 \mathrm{Btu} / \mathrm{h}(\geq 223 \mathrm{~kW})$ & $9.5 \mathrm{EER}$ & 3.30 \\
\hline (a) The size range applies to this work & & \\
\hline
\end{tabular}

\subsubsection{Economizer Use}

In advanced QSRs, the threshold limit on the size of a unit above which economizers are required was reduced from $65,000 \mathrm{Btu} / \mathrm{hr}$ in the baseline buildings to $54,000 \mathrm{Btu} / \mathrm{hr}$ according to Addendum $\mathrm{CY}$ to Standard 90.1-2007. This reduction allows for more use of airside economizers instead of mechanical cooling. In Table 4.20, the baseline economizer requirements are presented along with the requirements for advanced models to facilitate comparison. Other than the threshold values, in the advanced QSRs the use of economizers is expanded to climate zone $2 \mathrm{~A}, 3 \mathrm{~A}$, and $4 \mathrm{~A}$.

Table 4.20. Economizer Requirements in Addendum CY to Standard 90.1-2007

\begin{tabular}{|c|c|c|c|c|}
\hline \multirow[b]{2}{*}{$\begin{array}{l}\text { Climate } \\
\text { Zone }\end{array}$} & \multirow[b]{2}{*}{$\begin{array}{l}\text { Representative } \\
\text { City }\end{array}$} & \multicolumn{2}{|c|}{ Baseline models } & \multirow{2}{*}{$\begin{array}{c}\text { Advanced models } \\
\text { Economizer Required if } \\
\text { Cooling Capacity } \geq 54 \\
\mathrm{kBtu} / \mathrm{h}(16 \mathrm{~kW})\end{array}$} \\
\hline & & $\begin{array}{c}\text { Economizer Required if } \\
\text { Cooling Capacity } \geq 65 \\
\mathrm{kBtu} / \mathrm{h}(19 \mathrm{~kW}) \text { and } \\
<135 \mathrm{kBtu} / \mathrm{h}(40 \mathrm{~kW})\end{array}$ & $\begin{array}{c}\text { Economizer Required } \\
\text { if Cooling Capacity } \geq \\
135 \mathrm{kBtu} / \mathrm{h}(40 \mathrm{~kW})\end{array}$ & \\
\hline $1 \mathrm{~A}$ & Miami & No & No & No \\
\hline $2 \mathrm{~A}$ & Houston & No & No & Yes \\
\hline $2 \mathrm{~B}$ & Phoenix & No & Yes & Yes \\
\hline $3 \mathrm{~A}$ & Atlanta & No & No & Yes \\
\hline $3 \mathrm{~B}-\mathrm{CA}$ & Los Angeles & Yes & Yes & Yes \\
\hline 3B-other & Las Vegas & Yes & Yes & Yes \\
\hline $3 \mathrm{C}$ & San Francisco & Yes & Yes & Yes \\
\hline $4 \mathrm{~A}$ & Baltimore & No & No & Yes \\
\hline $4 \mathrm{~B}$ & Albuquerque & Yes & Yes & Yes \\
\hline $4 \mathrm{C}$ & Seattle & Yes & Yes & Yes \\
\hline $5 \mathrm{~A}$ & Chicago & No & Yes & Yes \\
\hline $5 \mathrm{~B}$ & Denver & Yes & Yes & Yes \\
\hline $6 \mathrm{~A}$ & Minneapolis & No & Yes & Yes \\
\hline $6 \mathrm{~B}$ & Helena & Yes & Yes & Yes \\
\hline 7 & Duluth & No & Yes & Yes \\
\hline 8 & Fairbanks & No & Yes & Yes \\
\hline
\end{tabular}




\subsection{Service Hot Water System}

\subsubsection{High Efficient Water Heater}

The use of service hot water in QSRs was analyzed in Section 3.5. The baseline model uses a standard gas-fired water heater with storage tank size of 100 gal $(379 \mathrm{~L})$, and the minimum required thermal efficiency established by Standard 90.12004 is $80 \%$. In the advanced model, a single gas-fired condensing water heater, with $95 \%$ thermal efficiency and typical storage, is recommended. The simulation is calibrated against field-measured data from similar "burger-based" QSR (FSTC 2007).

\subsubsection{Preheating Service Hot Water with Refrigerant Heat Recovery}

The refrigerant heat recovery system includes a 50-gal (189-L) storage tank with a passive heat exchanger and an insulated jacket. The refrigerant lines are routed from the evaporator through the heat recovery tank in route to the condensing unit. This approach maximizes heat extraction from the hot refrigerant before it reaches the condenser, thus saving compressor energy. The recovered waste refrigerant heat is used to preheat incoming city water before it is heated in the service hot water heater. In addition to lowering compressor energy use for the walk-in units, the heat recovery system is expected to provide an average of $3250 \mathrm{Btu} / \mathrm{h}(952 \mathrm{~W})$ of preheating to the domestic hot water system. EnergyPlus simulates water heaters with a cold water supply from the city main water line. The temperature of the water is assumed to be the monthly average temperatures of the outdoor air. Because the weekly hotwater use rate is known, i.e., $3557 \mathrm{gal} /$ week $(13,464 \mathrm{~L} /$ week), the preheating effects from the refrigerant recovery system on the domestic hot water system is equivalent to elevating the cold water supply temperature by $18.4^{\circ} \mathrm{F}\left(10.2^{\circ} \mathrm{C}\right)$. 


\subsection{Energy and Energy Cost Savings Results}

This chapter contains a summary of the EEMs, the estimated energy and energy cost savings results that are achieved by applying the EEMs described in Chapter 4.0. The combination of all the EEMs can achieve an aggregated energy saving of $45 \%$ across the nation, ranging from $41 \%$ to $52 \%$ by climates. The energy cost savings range from $40 \%$ to $48 \%$ in various climates and the national weighted-average energy cost savings is $43 \%$.

The project goal was to enable QSRs to achieve whole-building energy savings of at least $50 \%$ in all eight U.S. climate zones, but only the two coldest climates were able to reach the $50 \%$ energy-saving target. The key reason is that QSR is a special building type in which energy use is driven by very intensive process loads (i.e., the energy used for food preparation and storage). We have achieved significant energy savings in this area with optimized kitchen ventilation system and innovative food preparation/storage technologies, but technologies are not yet available (from multiple vendors) to allow us to attain the $50 \%$ energy savings goal in all climate zones. Not only the direct energy consumption of the food preparation process is a challenge to the $50 \%$ energy savings goal, but the space heat gain due to the equipment also has a great impact on the space cooling loads. Therefore, higher energy savings percentage is achieved in the cold climate zones than in the warm climate zones.

When excluding kitchen appliances and refrigeration, the energy savings from the building-related components are well beyond the 50\% energy saving goal, ranging from $55 \%$ in warm climates to $65 \%$ in cold climates. See Session 5.2 in this chapter for details.

\subsection{Summary of Recommended Energy Efficiency Measures}

This section summarizes the recommended EEMs in this report, which are grouped into envelope, lighting, commercial kitchen appliances, and building mechanical systems (including HVAC and service hot-water systems).

\section{Building Envelope Measures}

- Enhanced building opaque envelope insulation for exterior walls, roofs, and floor

- High-performance window glazing

- Cool roof in selected cooling dominant climates.

\section{Lighting Measures}

- Advanced indoor electric lighting fixtures to reduce interior connected lighting power

- Occupancy sensors to achieve lighting on-off control

- Minimize egress lighting and lock out all use of egress lighting when a building is unoccupied

- Daylight dimming control for dining zone to reduce electric lighting energy use

- Reduced exterior lighting power allowances

- Clock control to reduce the exterior lighting power when no occupants are present.

\section{Commercial Kitchen Appliance Measures}

- High-efficiency appliances on the main cook line

- Upgrading the unhooded appliances 
- High-efficiency refrigeration equipment

- High-efficiency walk-in refrigeration systems.

\section{Mechanical System Measures}

- High-efficiency proximity exhaust hoods for the main cook line

- Demand-control ventilation on exhaust hoods

- Dedicated outdoor air system (DOAS)

- Air-to-air heat recovery (runaround coil loop) from kitchen exhaust to DOAS

- Premium DX cooling equipment efficiency

- Extended economizer use

- High-efficiency water heater

- Preheating service hot water with refrigerant heat recovery.

\subsection{Energy Savings Results}

The QSR prototype building is simulated in each of the 16 climate locations to determine the energy saving potential of the EEMs described in Chapter 4.0. The whole-building energy savings results for the advanced buildings are described in this section, and the energy cost savings results are shown in Section 5.3. The energy savings are the site energy savings relative to the baseline energy use.

The site energy savings for all of the 16 climate locations are shown in Figure 5.1, ranging from 41\% to $52 \%$ by climate zone. Combining all the EEMs successfully reduced the site energy consumption of QSRs in climate zone 7 and 8 by more than $50 \%$. Table 5.1 shows EUIs in both baseline and advanced cases in all climate zones. Table 5.1 also presents the aggregate baseline EUI of $997 \mathrm{KBtu} / \mathrm{ft}^{2}(3,145$ $\left.\mathrm{kWh} / \mathrm{m}^{2}\right)$ and advanced EUI of $549 \mathrm{kBtu} / \mathrm{ft}^{2}\left(1,732 \mathrm{kWh} / \mathrm{m}^{2}\right)$, resulting in a national weighted-average percentage savings of $45 \%$.

Figure 5.2 shows the EUIs by energy end-use categories for both the baseline and advanced cases. The annual energy usage by end-use categories and total energy units in millions of Btus are shown in Table 5.2. The annual energy usage by fuel type is shown in Table 5.3 and Table 5.4.

Figure 5.3 shows the proportion of energy savings from different energy end uses as the national weighted-average savings. Approximately $50 \%$ of energy savings are from commercial kitchen appliances (i.e., electric and gas-fired appliances); the remaining savings are 37\% HVAC-related savings (i.e., heating, cooling, and fan), 7\% lighting-related savings, and $6 \%$ service water heating-related savings. Hooded cooking appliances on the main cooking line share the largest category with $39 \%$ savings. The reduced heat gain to the space due the efficient appliances is not yet included in this $39 \%$ savings. The graphical view of energy end-use categories shown in Figure 5.2 is a very good way to illustrate how much energy is consumed by various end-use categories. The spectrum is very different for the other prototype buildings previously studied and documented in AEDGs or TSDs.

QSRs are special buildings because the national weighted-average energy used for food preparation is about $62 \%$ of the total building energy consumption in baseline QSRs. Although significant energy savings have been achieved through commercial kitchen appliance EEMs as described in Section 4.3, to ensure the same business operation (i.e., number of customers, food quantity and quality), the food preparation process becomes the most significant barrier for QSRs to achieve the 50\% whole-building 
energy savings goal. As shown in Figure 5.2, the cooking and refrigeration energy uses combined amount to $62 \%$ and $72 \%$ of the total building energy uses in baseline and advanced QSRs, respectively. If these shares are removed from Figure 5.2, the energy savings from the other categories are well beyond the $50 \%$ energy saving goal as shown in Figure 5.4. It should be noted that Figure 5.4 is included only to illustrate the significance of food preparation on the whole building energy use. The effects of heat released to the conditioned space from food preparation are not excluded from Figure 5.4. More details on the energy saving impacts of different EEM packages are discussed in Section 5.4. 


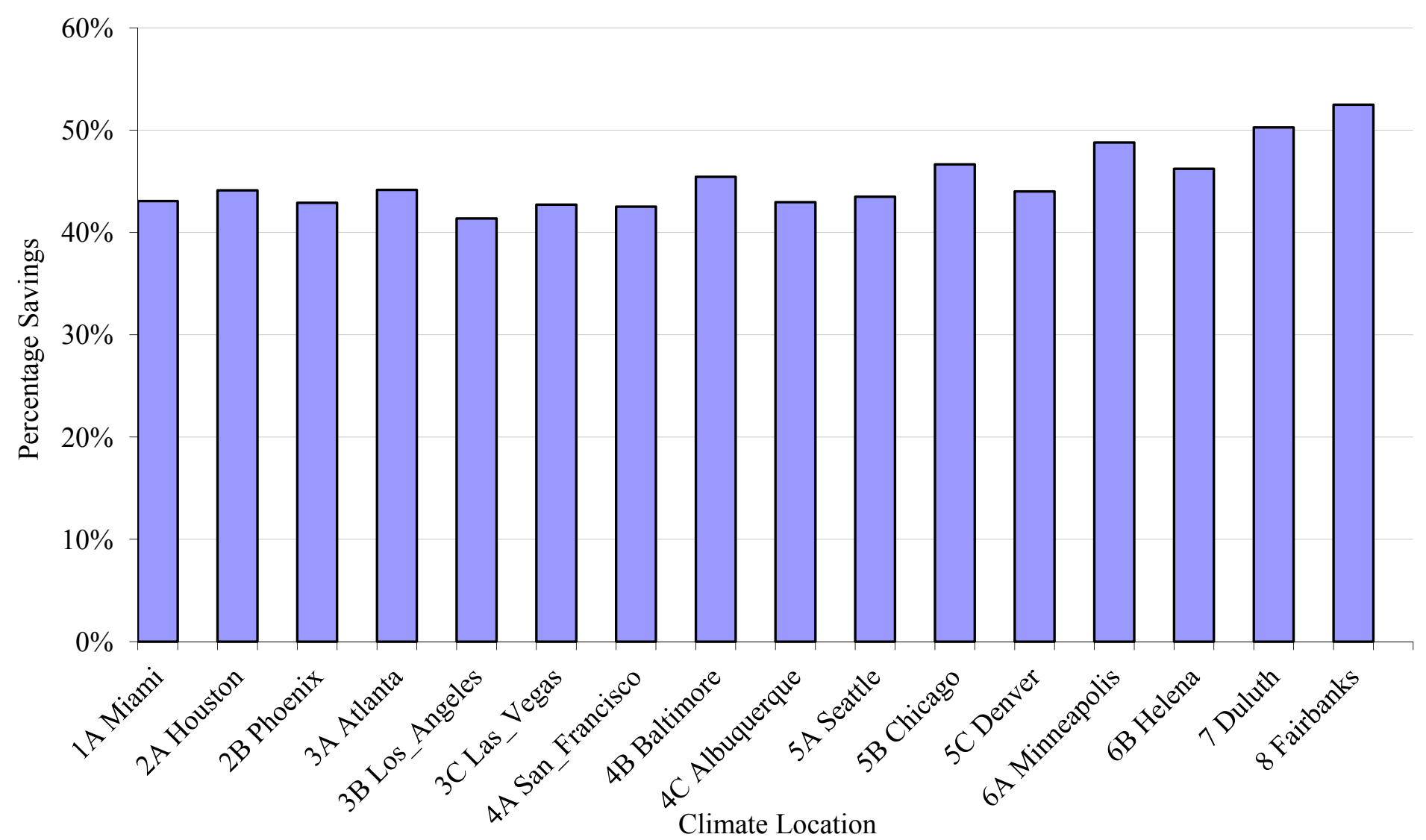

Figure 5.1. Percentage Energy Savings by Climate Zone 
Table 5.1. Energy Use Intensity Weighted by Construction Area

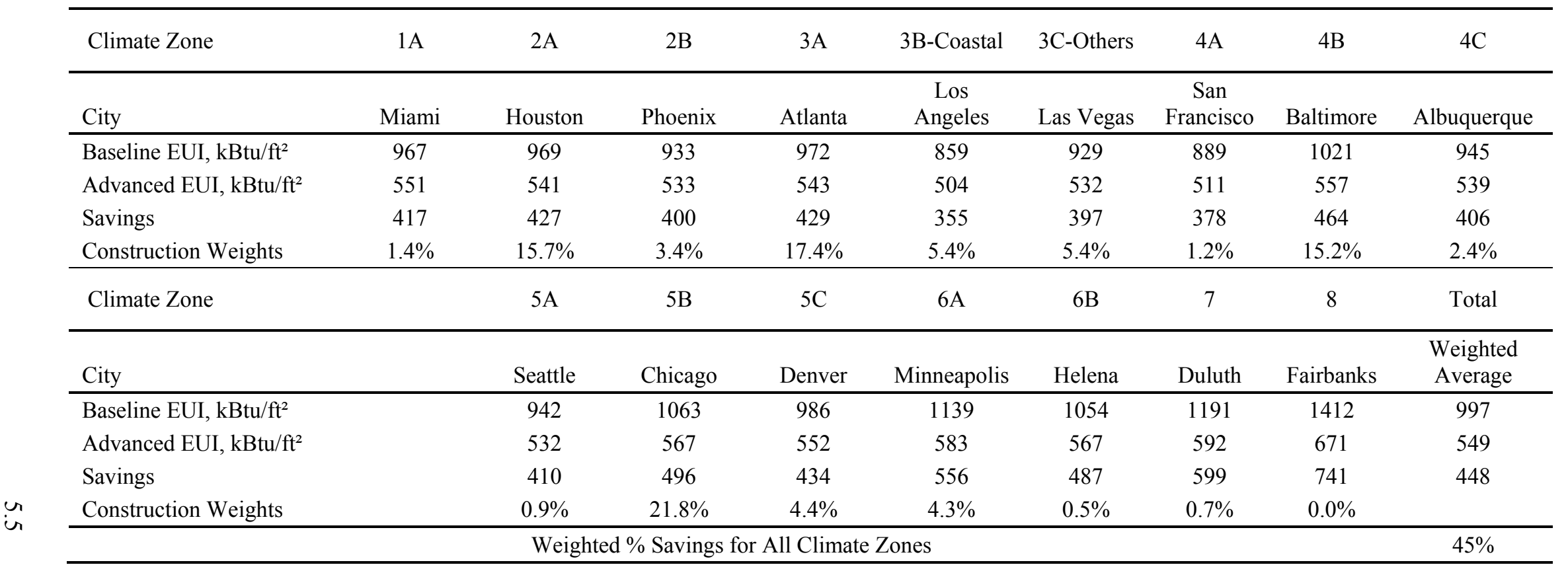




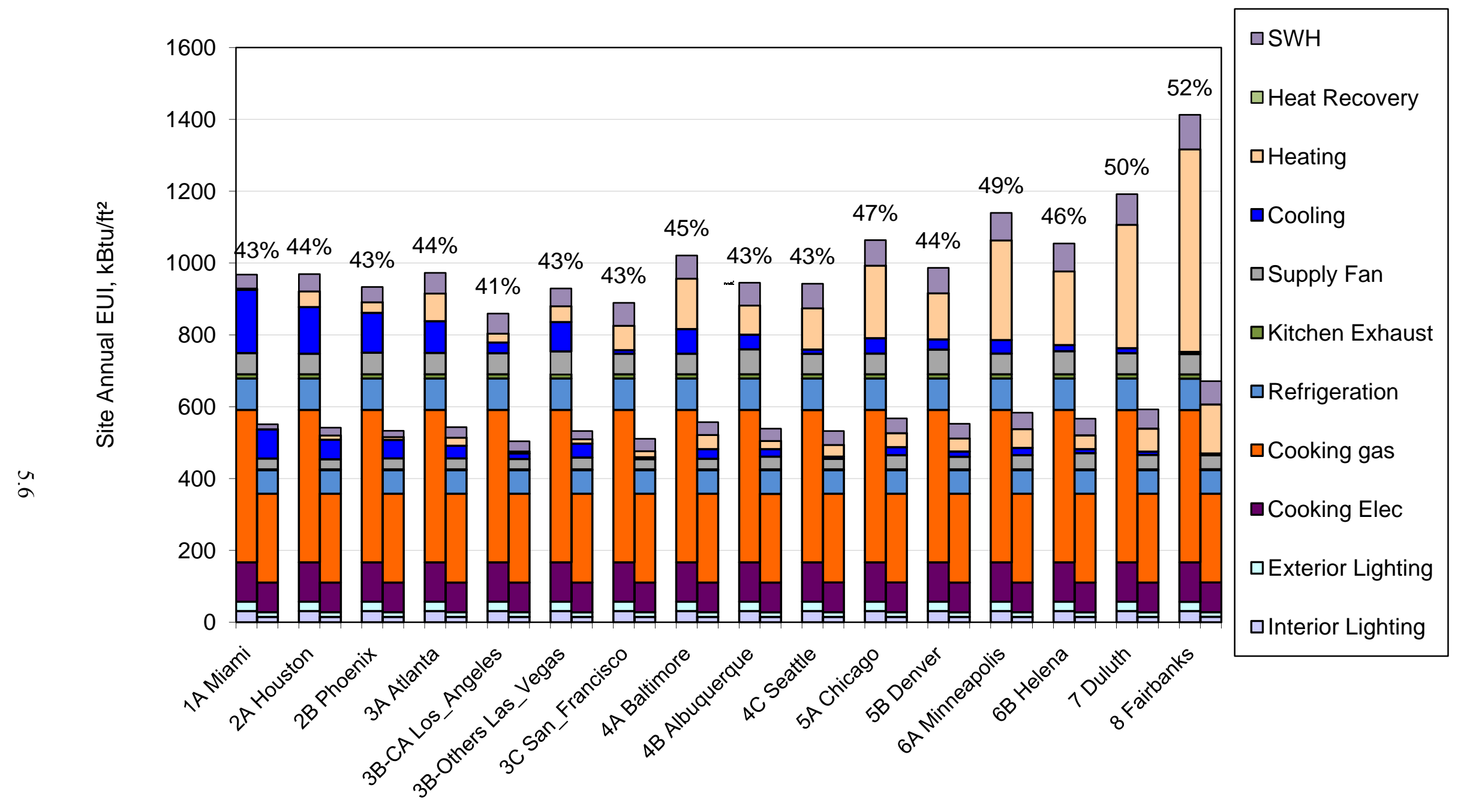

Figure 5.2. Energy Savings Results by Energy End-Use Categories 
Table 5.2. Energy Savings Results by Energy End-Use Categories

\begin{tabular}{|c|c|c|c|c|c|c|c|c|c|c|c|c|c|c|c|c|}
\hline $\begin{array}{l}\text { Climate } \\
\text { Zone }\end{array}$ & City & Model & $\begin{array}{l}\text { Interior } \\
\text { Lighting }\end{array}$ & $\begin{array}{l}\text { Exterior } \\
\text { Lighting }\end{array}$ & $\begin{array}{l}\text { Cooking } \\
\text { Elec }\end{array}$ & $\begin{array}{c}\text { Cooking } \\
\text { gas }\end{array}$ & Refrigeration & $\begin{array}{c}\text { Kitchen } \\
\text { Exhaust } \\
\text { Fan }\end{array}$ & $\begin{array}{l}\text { Supply } \\
\text { Fan }\end{array}$ & Cooling & Heating & $\begin{array}{c}\text { Heat } \\
\text { Recovery }\end{array}$ & SWH & Total & EUI & $\begin{array}{l}\text { Energy } \\
\text { Saving }\end{array}$ \\
\hline & & & MMBtu & MMBtu & MMBtu & MMBtu & MMBtu & MMBtu & MMBtu & MMBtu & MMBtu & MMBtu & MMBtu & MMBtu & $\mathrm{kBtu} / \mathrm{sf}$ & $\%$ \\
\hline \multirow{2}{*}{$1 \mathrm{~A}$} & \multirow{2}{*}{ Miami } & Baseline & 78 & 65 & 275 & 1,060 & 218 & 30 & 148 & 439 & 10 & 0 & 97 & 2,420 & 967 & \multirow{2}{*}{$43 \%$} \\
\hline & & Advanced & 37 & 33 & 207 & 618 & 165 & 5 & 75 & 201 & 3 & 0 & 34 & 1,378 & 551 & \\
\hline \multirow{2}{*}{$2 \mathrm{~A}$} & \multirow{2}{*}{ Houston } & Baseline & 78 & 65 & 275 & 1,060 & 218 & 30 & 144 & 325 & 109 & 0 & 120 & 2,423 & 969 & \multirow{2}{*}{$44 \%$} \\
\hline & & Advanced & 37 & 33 & 207 & 618 & 165 & 5 & 70 & 135 & 31 & 0 & 54 & 1,354 & 541 & \\
\hline \multirow{2}{*}{ 2B } & \multirow{2}{*}{ Phoenix } & Baseline & 78 & 65 & 275 & 1,060 & 218 & 30 & 151 & 277 & 73 & 0 & 106 & 2,334 & 933 & \multirow{2}{*}{$43 \%$} \\
\hline & & Advanced & 37 & 33 & 207 & 618 & 165 & 5 & 76 & 129 & 20 & 0 & 44 & 1,333 & 533 & \\
\hline \multirow{2}{*}{$3 \mathrm{~A}$} & \multirow{2}{*}{ Atlanta } & Baseline & 78 & 65 & 275 & 1,060 & 218 & 30 & 149 & 221 & 193 & 0 & 144 & 2,432 & 972 & \multirow{2}{*}{$44 \%$} \\
\hline & & Advanced & 37 & 33 & 207 & 618 & 165 & 5 & 76 & 88 & 56 & 0 & 73 & 1,358 & 543 & \\
\hline \multirow{2}{*}{ 3B-CA } & \multirow{2}{*}{ Los_Angeles } & Baseline & 78 & 65 & 275 & 1,060 & 218 & 30 & 147 & 74 & 63 & 0 & 139 & 2,148 & 859 & \multirow{2}{*}{$41 \%$} \\
\hline & & Advanced & 37 & 33 & 207 & 618 & 165 & 5 & 72 & 38 & 15 & 0 & 70 & 1,259 & 504 & \\
\hline \multirow{2}{*}{ 3B-other } & \multirow{2}{*}{ Las_Vegas } & Baseline & 78 & 65 & 275 & 1,060 & 218 & 30 & 159 & 205 & 110 & 0 & 123 & 2,323 & 929 & \multirow{2}{*}{$43 \%$} \\
\hline & & Advanced & 37 & 33 & 207 & 618 & 165 & 5 & 83 & 97 & 31 & 0 & 57 & 1,331 & 532 & \\
\hline \multirow{2}{*}{$3 \mathrm{C}$} & \multirow{2}{*}{ San_Francisco } & Baseline & 78 & 65 & 275 & 1,060 & 218 & 30 & 144 & 24 & 171 & 0 & 159 & 2,223 & 889 & \multirow{2}{*}{$43 \%$} \\
\hline & & Advanced & 37 & 33 & 207 & 618 & 165 & 5 & 72 & 13 & 43 & 0 & 86 & 1,278 & 511 & \\
\hline \multirow{2}{*}{$4 \mathrm{~A}$} & \multirow{2}{*}{ Baltimore } & Baseline & 78 & 65 & 275 & 1,060 & 218 & 30 & 144 & 171 & 351 & 0 & 161 & 2,553 & 1,021 & \multirow{2}{*}{$45 \%$} \\
\hline & & Advanced & 37 & 33 & 207 & 618 & 165 & 5 & 74 & 67 & 100 & 0 & 88 & 1,393 & 557 & \\
\hline $4 \mathrm{~B}$ & Albuqueraue & Baseline & 78 & 65 & 275 & 1,060 & 218 & 30 & 174 & 101 & 204 & 0 & 158 & 2,363 & 945 & $43 \%$ \\
\hline $4 \mathrm{D}$ & 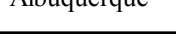 & Advanced & 37 & 33 & 207 & 618 & 165 & 5 & 89 & 53 & 57 & 0 & 86 & 1,348 & 539 & $45 \%$ \\
\hline $4 C$ & & Baseline & 78 & 64 & 275 & 1,060 & 218 & 30 & 143 & 29 & 287 & 0 & 171 & 2,356 & 942 & \\
\hline $4 \mathrm{C}$ & Seattle & Advanced & 37 & 33 & 207 & 618 & 165 & 5 & 73 & 15 & 82 & 0 & 97 & 1,331 & 532 & $43 \%$ \\
\hline & & Baseline & 78 & 65 & 275 & 1,060 & 218 & 30 & 145 & 107 & 505 & 0 & 177 & 2,660 & 1,063 & \\
\hline $5 \mathrm{~A}$ & Chicago & Advanced & 37 & 33 & 207 & 618 & 165 & 5 & 99 & 56 & 97 & 1 & 102 & 1,419 & 567 & $47 \%$ \\
\hline & & Baseline & 78 & 64 & 275 & 1,060 & 218 & 30 & 173 & 70 & 322 & 0 & 177 & 2,467 & 986 & $44 \%$ \\
\hline $5 \mathrm{~B}$ & Denver & Advanced & 37 & 33 & 207 & 618 & 165 & 5 & 88 & 36 & 91 & 0 & 101 & 1,381 & 552 & $44 \%$ \\
\hline & & Baseline & 78 & 64 & 275 & 1,060 & 218 & 30 & 145 & 94 & 694 & 0 & 191 & 2,849 & 1,139 & \\
\hline $6 \mathrm{~A}$ & Minneapolis & Advanced & 37 & 33 & 207 & 618 & 165 & 5 & 100 & 50 & 130 & 1 & 114 & 1,459 & 583 & $49 \%$ \\
\hline $6 \mathrm{~B}$ & Helena & Baseline & 78 & 64 & 275 & 1,060 & 218 & 30 & 161 & 43 & 513 & 0 & 193 & 2,636 & 1,054 & $46 \%$ \\
\hline OB & Helena & Advanced & 37 & 33 & 207 & 618 & 165 & 5 & 113 & 28 & 96 & 1 & 115 & 1,417 & 567 & $40 \%$ \\
\hline 7 & Duluth & Baseline & 78 & 64 & 275 & 1,060 & 218 & 30 & 147 & 34 & 859 & 0 & 213 & 2,980 & 1,191 & $50 \%$ \\
\hline 1 & Duiutn & Advanced & 37 & 33 & 207 & 618 & 165 & 5 & 101 & 23 & 160 & 1 & 132 & 1,482 & 592 & $50 \%$ \\
\hline 8 & Fairhanks & Baseline & 78 & 64 & 275 & 1,060 & 218 & 30 & 141 & 15 & 1,410 & 0 & 241 & 3,532 & 1,412 & $52 \%$ \\
\hline 0 & 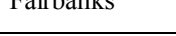 & Advanced & 38 & 33 & 207 & 618 & 165 & 5 & 98 & 12 & 341 & 2 & 161 & 1,678 & 671 & $52 \%$ \\
\hline
\end{tabular}


Table 5.3. Electricity (kWh) Savings Results by End-Use Category

\begin{tabular}{|c|c|c|c|c|c|c|c|c|c|c|}
\hline $\begin{array}{l}\text { Climate } \\
\text { Zone }\end{array}$ & City & Model & $\begin{array}{l}\text { Interior } \\
\text { Lighting }\end{array}$ & $\begin{array}{l}\text { Exterior } \\
\text { Lighting }\end{array}$ & Cooking & Refrigeration & $\begin{array}{c}\text { Kitchen } \\
\text { Exhaust } \\
\text { Fan }\end{array}$ & $\begin{array}{c}\text { Supply } \\
\text { Fan }\end{array}$ & Cooling & Total \\
\hline & & & $\mathrm{kWh}$ & $\mathrm{kWh}$ & $\mathrm{kWh}$ & $\mathrm{kWh}$ & $\mathrm{kWh}$ & $\mathrm{kWh}$ & $\mathrm{kWh}$ & $\mathrm{kWh}$ \\
\hline \multirow{2}{*}{$1 \mathrm{~A}$} & \multirow{2}{*}{ Miami } & Baseline & 22,956 & 18,941 & 80,464 & 64,000 & 8,648 & 43,481 & 128,742 & 367,232 \\
\hline & & Advanced & 10,889 & 9,557 & 60,605 & 48,273 & 1,534 & 22,122 & 59,044 & 212,024 \\
\hline \multirow{2}{*}{$2 \mathrm{~A}$} & \multirow{2}{*}{ Houston } & Baseline & 22,956 & 18,936 & 80,464 & 64,000 & 8,648 & 42,089 & 95,152 & 332,244 \\
\hline & & Advanced & 10,907 & 9,551 & 60,605 & 48,273 & 1,534 & 20,661 & 39,625 & 191,156 \\
\hline \multirow{2}{*}{$2 \mathrm{~B}$} & \multirow{2}{*}{ Phoenix } & Baseline & 22,956 & 18,930 & 80,464 & 64,000 & 8,648 & 44,286 & 81,297 & 320,582 \\
\hline & & Advanced & 10,876 & 9,551 & 60,605 & 48,273 & 1,534 & 22,334 & 37,713 & 190,887 \\
\hline \multirow{2}{*}{$3 \mathrm{~A}$} & \multirow{2}{*}{ Atlanta } & Baseline & 22,956 & 18,928 & 80,464 & 64,000 & 8,648 & 43,756 & 64,698 & 303,449 \\
\hline & & Advanced & 10,888 & 9,548 & 60,605 & 48,273 & 1,534 & 22,397 & 25,726 & 178,971 \\
\hline \multirow{2}{*}{ 3B-CA } & \multirow{2}{*}{ Los_Angeles } & Baseline & 22,956 & 18,914 & 80,464 & 64,000 & 8,648 & 43,142 & 21,586 & 259,710 \\
\hline & & Advanced & 10,896 & 9,546 & 60,605 & 48,273 & 1,534 & 21,203 & 11,168 & 163,225 \\
\hline \multirow{2}{*}{ 3B-other } & \multirow{2}{*}{ Las_Vegas } & Baseline & 22,956 & 18,911 & 80,464 & 64,000 & 8,648 & 46,628 & 59,997 & 301,604 \\
\hline & & Advanced & 10,865 & 9,557 & 60,605 & 48,273 & 1,534 & 24,228 & 28,329 & 183,391 \\
\hline \multirow{2}{*}{$3 \mathrm{C}$} & \multirow{2}{*}{ San_Francisco } & Baseline & 22,956 & 18,919 & 80,464 & 64,000 & 8,648 & 42,172 & 6,998 & 244,158 \\
\hline & & Advanced & 10,899 & 9,546 & 60,605 & 48,273 & 1,534 & 20,994 & 3,673 & 155,524 \\
\hline \multirow{2}{*}{$4 \mathrm{~A}$} & \multirow{2}{*}{ Baltimore } & Baseline & 22,956 & 18,908 & 80,464 & 64,000 & 8,648 & 42,256 & 50,048 & 287,280 \\
\hline & & Advanced & 10,899 & 9,543 & 60,605 & 48,273 & 1,534 & 21,592 & 19,564 & 172,009 \\
\hline \multirow{2}{*}{ 4B } & \multirow{2}{*}{ Albuquerque } & Baseline & 22,956 & 18,916 & 80,464 & 64,000 & 8,648 & 51,118 & 29,648 & 275,751 \\
\hline & & Advanced & 10,865 & 9,543 & 60,605 & 48,273 & 1,534 & 26,015 & 15,405 & 172,240 \\
\hline \multirow{2}{*}{$4 \mathrm{C}$} & \multirow{2}{*}{ Seattle } & Baseline & 22,956 & 18,878 & 80,464 & 64,000 & 8,648 & 41,992 & 8,626 & 245,563 \\
\hline & & Advanced & 10,974 & 9,537 & 60,605 & 48,273 & 1,534 & 21,445 & 4,467 & 156,835 \\
\hline \multirow{2}{*}{$5 \mathrm{~A}$} & \multirow{2}{*}{ Chicago } & Baseline & 22,956 & 18,911 & 80,464 & 64,000 & 8,648 & 42,433 & 31,357 & 268,769 \\
\hline & & Advanced & 10,918 & 9,560 & 60,605 & 48,273 & 1,534 & 28,940 & 16,399 & 176,229 \\
\hline \multirow{2}{*}{$5 \mathrm{~B}$} & \multirow{2}{*}{ Denver } & Baseline & 22,956 & 18,900 & 80,464 & 64,000 & 8,648 & 50,568 & 20,544 & 266,080 \\
\hline & & Advanced & 10,876 & 9,543 & 60,605 & 48,273 & 1,534 & 25,823 & 10,649 & 167,303 \\
\hline \multirow{2}{*}{$6 \mathrm{~A}$} & \multirow{2}{*}{ Minneapolis } & Baseline & 22,956 & 18,900 & 80,464 & 64,000 & 8,648 & 42,350 & 27,504 & 264,821 \\
\hline & & Advanced & 10,885 & 9,543 & 60,605 & 48,273 & 1,534 & 29,173 & 14,791 & 174,804 \\
\hline \multirow{2}{*}{$6 \mathrm{~B}$} & & Baseline & 22,956 & 18,894 & 80,464 & 64,000 & 8,648 & 47,159 & 12,568 & 254,690 \\
\hline & & Advanced & 10,879 & 9,535 & 60,605 & 48,273 & 1,534 & 33,041 & 8,179 & 172,045 \\
\hline 7 & & Baseline & 22,956 & 18,883 & 80,464 & 64,000 & 8,648 & 43,220 & 10,051 & 248,222 \\
\hline 1 & Duilum & Advanced & 10,882 & 9,540 & 60,605 & 48,273 & 1,534 & 29,618 & 6,640 & 167,092 \\
\hline 8 & & Baseline & 22,956 & 18,769 & 80,464 & 64,000 & 8,648 & 41,397 & 4,489 & 240,724 \\
\hline 8 & $\mathrm{~F}$ & Advanced & 10,999 & 9,612 & 60,605 & 48,273 & 1,534 & 28,604 & 3,562 & 163,188 \\
\hline
\end{tabular}


Table 5.4. Natural Gas (therms) Savings Results by End-Use Category

\begin{tabular}{|c|c|c|c|c|c|c|}
\hline \multirow[t]{2}{*}{$\begin{array}{l}\text { Climate } \\
\text { Zone }\end{array}$} & \multirow[t]{2}{*}{ City } & \multirow[t]{2}{*}{ Model } & \multirow{2}{*}{$\begin{array}{l}\text { Cooking } \\
\text { Therms }\end{array}$} & \multirow{2}{*}{$\begin{array}{l}\text { Heating } \\
\text { Therms }\end{array}$} & \multirow{2}{*}{$\begin{array}{c}\text { SWH } \\
\text { Therms }\end{array}$} & \multirow{2}{*}{$\begin{array}{l}\text { Total } \\
\text { Therm }\end{array}$} \\
\hline & & & & & & \\
\hline \multirow{2}{*}{$1 \mathrm{~A}$} & \multirow{2}{*}{ Miami } & Baseline & 10,602 & 97 & 967 & 11,666 \\
\hline & & Advanced & 6,176 & 26 & 340 & 6,542 \\
\hline \multirow{2}{*}{$2 \mathrm{~A}$} & \multirow{2}{*}{ Houston } & Baseline & 10,602 & 1,093 & 1,202 & 12,897 \\
\hline & & Advanced & 6,176 & 305 & 538 & 7,020 \\
\hline \multirow{2}{*}{ 2B } & \multirow{2}{*}{ Phoenix } & Baseline & 10,602 & 735 & 1,065 & 12,402 \\
\hline & & Advanced & 6,176 & 200 & 439 & 6,815 \\
\hline \multirow{2}{*}{$3 \mathrm{~A}$} & \multirow{2}{*}{ Atlanta } & Baseline & 10,602 & 1,929 & 1,435 & 13,966 \\
\hline & & Advanced & 6,176 & 562 & 735 & 7,473 \\
\hline \multirow{2}{*}{ 3B-CA } & \multirow{2}{*}{ Los_Angeles } & Baseline & 10,602 & 627 & 1,391 & 12,620 \\
\hline & & Advanced & 6,176 & 151 & 697 & 7,025 \\
\hline \multirow{2}{*}{ 3B-other } & \multirow{2}{*}{ Las_Vegas } & Baseline & 10,602 & 1,104 & 1,234 & 12,940 \\
\hline & & Advanced & 6,176 & 307 & 565 & 7,049 \\
\hline \multirow{2}{*}{$3 \mathrm{C}$} & \multirow{2}{*}{ San_Francisco } & Baseline & 10,602 & 1,709 & 1,587 & 13,898 \\
\hline & & Advanced & 6,176 & 430 & 862 & 7,468 \\
\hline \multirow{2}{*}{$4 \mathrm{~A}$} & \multirow{2}{*}{ Baltimore } & Baseline & 10,602 & 3,512 & 1,613 & 15,727 \\
\hline & & Advanced & 6,176 & 997 & 884 & 8,058 \\
\hline \multirow{2}{*}{ 4B } & \multirow{2}{*}{ Albuquerque } & Baseline & 10,602 & 2,039 & 1,579 & 14,219 \\
\hline & & Advanced & 6,176 & 567 & 856 & 7,598 \\
\hline \multirow{2}{*}{$4 \mathrm{C}$} & \multirow{2}{*}{ Seattle } & Baseline & 10,602 & 2,874 & 1,710 & 15,186 \\
\hline & & Advanced & 6,176 & 821 & 966 & 7,963 \\
\hline \multirow{2}{*}{$5 \mathrm{~A}$} & \multirow{2}{*}{ Chicago } & Baseline & 10,602 & 5,053 & 1,771 & 17,426 \\
\hline & & Advanced & 6,176 & 967 & 1,017 & 8,160 \\
\hline $5 \mathrm{R}$ & Denyer & Baseline & 10,602 & 3,221 & 1,766 & 15,589 \\
\hline JD & Denver & Advanced & 6,176 & 915 & 1,013 & 8,104 \\
\hline $6 \mathrm{~A}$ & Minneanolis & Baseline & 10,602 & 6,941 & 1,911 & 19,455 \\
\hline & Minneapons & Advanced & 6,176 & 1,298 & 1,136 & 8,609 \\
\hline $6 \mathrm{~B}$ & Helena & Baseline & 10,602 & 5,135 & 1,932 & 17,669 \\
\hline $6 \mathrm{~B}$ & Helena & Advanced & 6,176 & 961 & 1,153 & 8,289 \\
\hline 7 & Duluth & Baseline & 10,602 & 8,592 & 2,133 & 21,328 \\
\hline & Duluth & Advanced & 6,176 & 1,601 & 1,323 & 9,099 \\
\hline 8 & Fairbanks & Baseline & 10,602 & 14,101 & 2,407 & 27,110 \\
\hline 8 & Faurbanks & Advanced & 6,176 & 3,410 & 1,614 & 11,200 \\
\hline
\end{tabular}




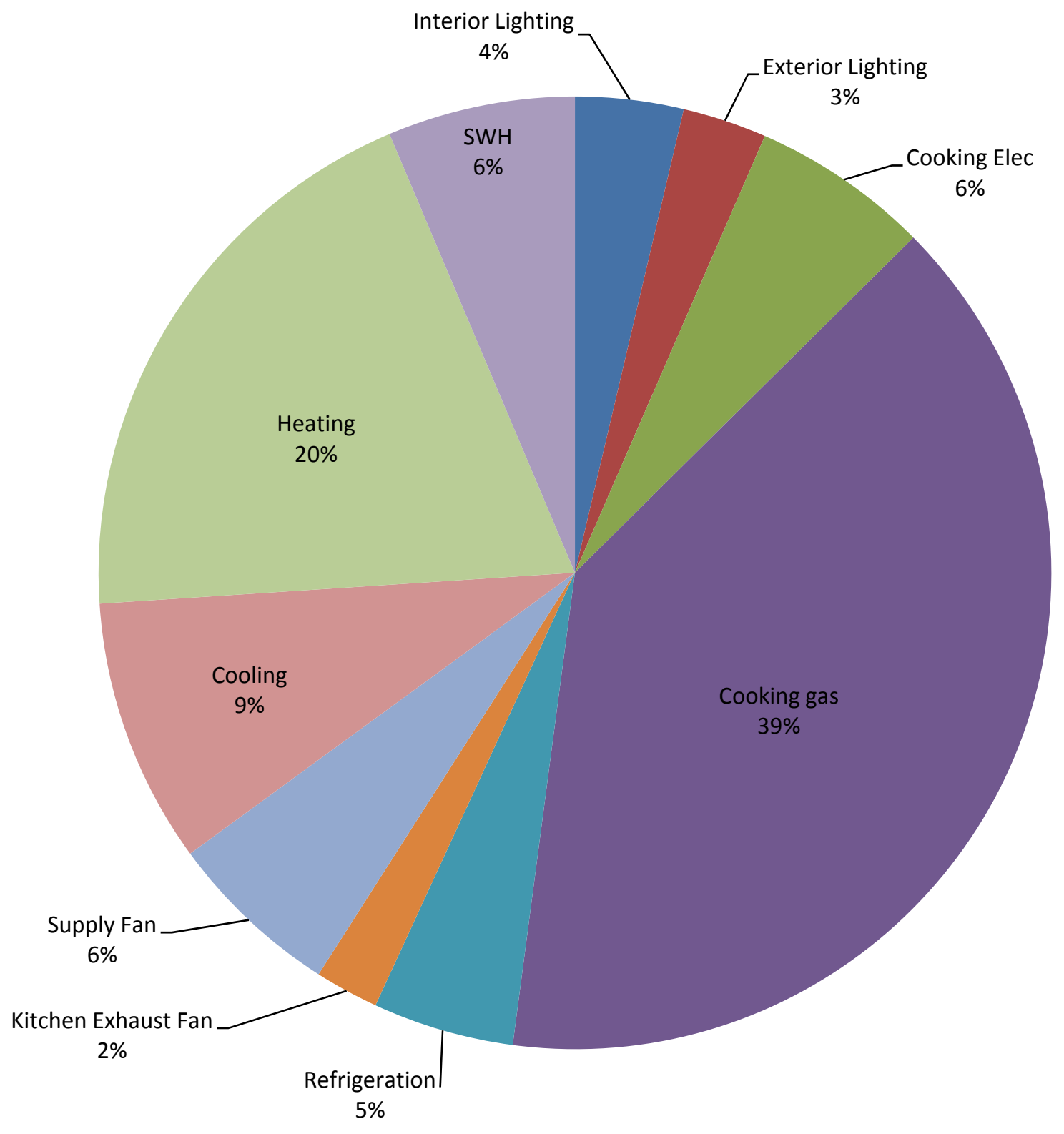

Figure 5.3. Proportion of Energy Savings from Different End-Use Categories 


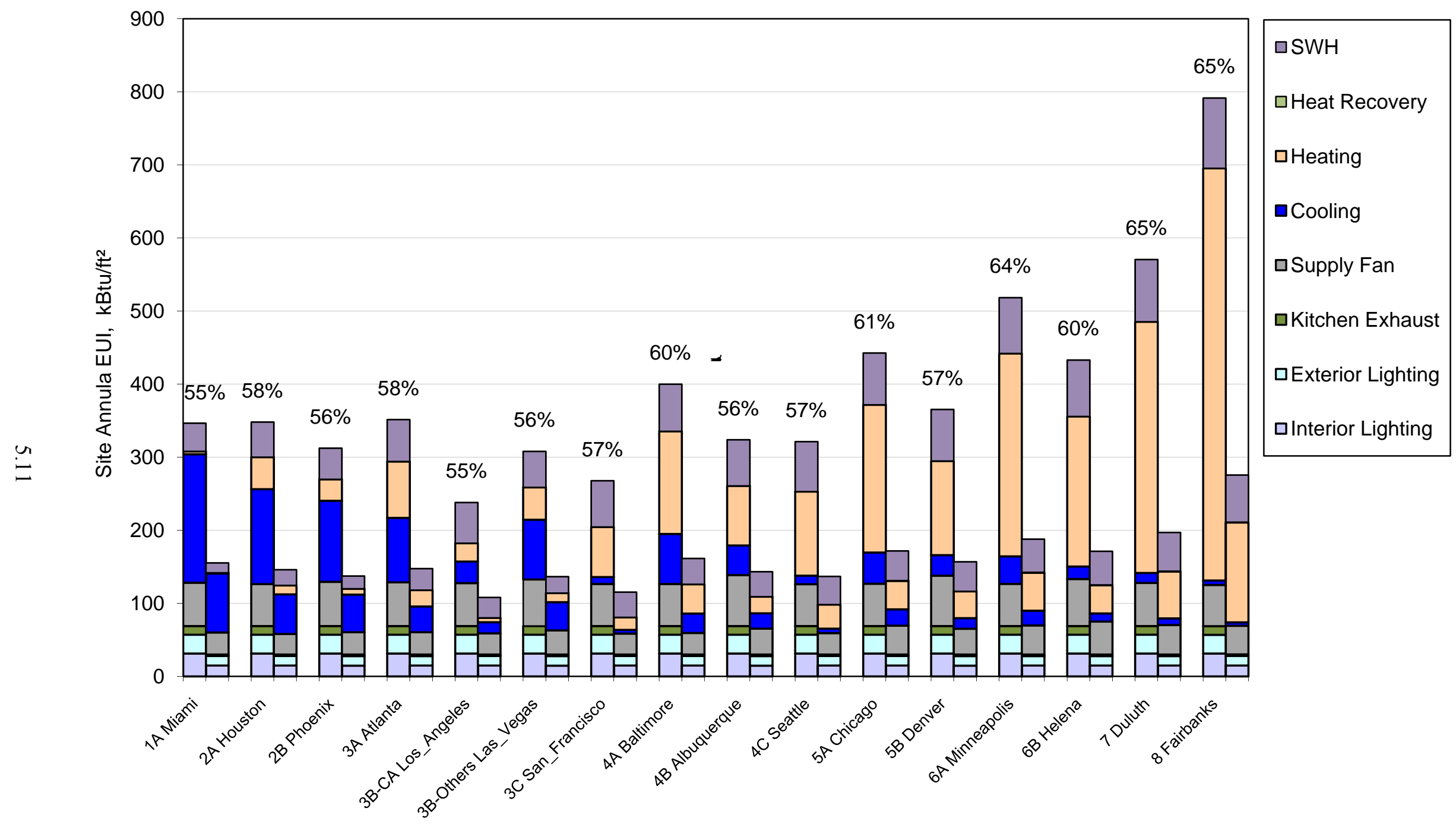

Figure 5.4. Energy Savings Results by Energy End-Use Categories Excluding Refrigeration and Cooking Appliances 


\subsection{Energy Cost Savings Results}

Energy cost savings, as shown in Table 5.5, are calculated using the same energy prices as those adopted by the SSPC 90.1 in developing Standard 90.1-2010. These energy prices, derived from EIA values, are $\$ 1.16 /$ therm $\left(\$ 0.41 / \mathrm{m}^{3}\right)$ for natural gas and $\$ 0.0939 / \mathrm{kWh}$ for electricity (EIA 2007). Energy cost savings range from about $\$ 15,500$ to $\$ 25,700$ annually, ranging from $40 \%$ to $48 \%$. The national weighted-average cost savings is $43 \%$.

Table 5.5. Annual Energy Cost Reduction

\begin{tabular}{|c|c|c|c|c|c|c|c|c|}
\hline $\begin{array}{l}\text { Climate } \\
\text { Zone }\end{array}$ & City & $\begin{array}{l}\text { Electricity } \\
\text { Savings, } \\
\text { (kWh) }\end{array}$ & $\begin{array}{l}\text { Natural } \\
\text { Gas } \\
\text { Savings, } \\
\text { (therms) }\end{array}$ & $\begin{array}{c}\text { Electricity } \\
\text { Cost } \\
\text { Savings }\end{array}$ & $\begin{array}{c}\text { Natural } \\
\text { Gas } \\
\text { Cost } \\
\text { Savings }\end{array}$ & $\begin{array}{c}\text { Total } \\
\text { Cost } \\
\text { Savings }\end{array}$ & $\begin{array}{c}\text { Baseline } \\
\text { Energy } \\
\text { Cost }\end{array}$ & $\begin{array}{l}\text { Energy } \\
\text { Cost \% } \\
\text { Savings }\end{array}$ \\
\hline $1 \mathrm{~A}$ & Miami & 155,212 & 5,124 & $\$ 14,574$ & $\$ 5,944$ & $\$ 20,518$ & $\$ 48,016$ & $43 \%$ \\
\hline $2 \mathrm{~A}$ & Houston & 141,088 & 5,878 & $\$ 13,248$ & $\$ 6,818$ & $\$ 20,066$ & $\$ 46,158$ & $43 \%$ \\
\hline $2 \mathrm{~B}$ & Phoenix & 129,695 & 5,587 & $\$ 12,178$ & $\$ 6,481$ & $\$ 18,659$ & $\$ 44,489$ & $42 \%$ \\
\hline $3 \mathrm{~A}$ & Atlanta & 124,478 & 6,493 & $\$ 11,688$ & $\$ 7,532$ & $\$ 19,220$ & $\$ 44,695$ & $43 \%$ \\
\hline 3B-CA & Los Angeles & 96,485 & 5,595 & $\$ 9,060$ & $\$ 6,490$ & $\$ 15,550$ & $\$ 39,026$ & $40 \%$ \\
\hline 3B-other & Las Vegas & 118,213 & 5,891 & $\$ 11,100$ & $\$ 6,834$ & $\$ 17,934$ & $\$ 43,331$ & $41 \%$ \\
\hline $3 \mathrm{C}$ & San Francisco & 88,634 & 6,429 & $\$ 8,323$ & $\$ 7,458$ & $\$ 15,781$ & $\$ 39,048$ & $40 \%$ \\
\hline $4 \mathrm{~A}$ & Baltimore & 115,271 & 7,669 & $\$ 10,824$ & $\$ 8,896$ & $\$ 19,720$ & $\$ 45,219$ & $44 \%$ \\
\hline 4B & Albuquerque & 103,511 & 6,621 & $\$ 9,720$ & $\$ 7,680$ & $\$ 17,400$ & $\$ 42,387$ & $41 \%$ \\
\hline $4 \mathrm{C}$ & Seattle & 88,729 & 7,223 & $\$ 8,332$ & $\$ 8,378$ & $\$ 16,710$ & $\$ 40,674$ & $41 \%$ \\
\hline $5 \mathrm{~A}$ & Chicago & 92,540 & 9,266 & $\$ 8,690$ & $\$ 10,748$ & $\$ 19,438$ & $\$ 45,451$ & $43 \%$ \\
\hline $5 \mathrm{~B}$ & Denver & 98,777 & 7,485 & $\$ 9,275$ & $\$ 8,683$ & $\$ 17,958$ & $\$ 43,068$ & $42 \%$ \\
\hline $6 \mathrm{~A}$ & Minneapolis & 90,018 & 10,845 & $\$ 8,453$ & $\$ 12,580$ & $\$ 21,033$ & $\$ 47,434$ & $44 \%$ \\
\hline $6 \mathrm{~B}$ & Helena & 82,644 & 9,379 & $\$ 7,760$ & $\$ 10,880$ & $\$ 18,640$ & $\$ 44,411$ & $42 \%$ \\
\hline 7 & Duluth & 81,130 & 12,229 & $\$ 7,618$ & $\$ 14,185$ & $\$ 21,803$ & $\$ 48,048$ & $45 \%$ \\
\hline 8 & Fairbanks & 77,535 & 15,910 & $\$ 7,281$ & $\$ 18,456$ & $\$ 25,737$ & $\$ 54,051$ & $48 \%$ \\
\hline
\end{tabular}

\subsection{Energy and Energy Cost Savings Results of EEM Packages}

The whole building energy savings and energy cost savings results have been shown in the previous sections. When a design team or a business owner prepares the design for a new QSR, the investment budget often is limited, and they may want to know the benefit of implementing various combinations of the EEMs. Therefore, the authors decided to present the energy savings and energy cost savings results of four EEM packages with each covering one category of the EEMs, i.e., building envelope measures, lighting measures, commercial kitchen appliance measures, and mechanical system measures (Table 5.6 through Table 5.13). The results shown in this section will be discussed in Section 6.3 with the cost effectiveness analysis results for the four EEM packages. 
Table 5.6. Energy Savings Results for the Building Envelope EEM Package

\begin{tabular}{|c|c|c|c|c|c|c|c|c|c|c|c|c|c|c|c|c|}
\hline $\begin{array}{l}\text { Climate } \\
\text { Zone }\end{array}$ & City & Model & $\begin{array}{l}\text { Interior } \\
\text { Lighting }\end{array}$ & $\begin{array}{l}\text { Exterior } \\
\text { Lighting }\end{array}$ & $\begin{array}{l}\text { Cooking } \\
\text { Elec }\end{array}$ & $\begin{array}{c}\text { Cooking } \\
\text { gas }\end{array}$ & Refrigeration & $\begin{array}{c}\text { Kitchen } \\
\text { Exhaust } \\
\text { Fan }\end{array}$ & $\begin{array}{l}\text { Supply } \\
\text { Fan }\end{array}$ & Cooling & Heating & $\begin{array}{c}\text { Heat } \\
\text { Recovery }\end{array}$ & SWH & Total & EUI & $\begin{array}{l}\text { Energy } \\
\text { Saving }\end{array}$ \\
\hline & & & MMBtu & MMBtu & MMBtu & MMBtu & MMBtu & MMBtu & MMBtu & MMBtu & MMBtu & MMBtu & MMBtu & MMBtu & $\mathrm{kBtu} / \mathrm{sf}$ & $\%$ \\
\hline \multirow{2}{*}{$1 \mathrm{~A}$} & \multirow{2}{*}{ Miami } & Baseline & 78 & 65 & 275 & 1060 & 218 & 30 & 148 & 439 & 10 & 0 & 97 & 2,420 & 968 & \multirow{2}{*}{$0 \%$} \\
\hline & & Advanced & 78 & 65 & 275 & 1060 & 218 & 30 & 148 & 439 & 9 & 0 & 97 & 2,419 & 967 & \\
\hline \multirow{2}{*}{$2 \mathrm{~A}$} & \multirow{2}{*}{ Houston } & Baseline & 78 & 65 & 275 & 1060 & 218 & 30 & 144 & 325 & 109 & 0 & 120 & 2,423 & 969 & \multirow{2}{*}{$0 \%$} \\
\hline & & Advanced & 78 & 65 & 275 & 1060 & 218 & 30 & 143 & 325 & 100 & 0 & 120 & 2,414 & 966 & \\
\hline \multirow{2}{*}{ 2B } & \multirow{2}{*}{ Phoenix } & Baseline & 78 & 65 & 275 & 1060 & 218 & 30 & 151 & 277 & 73 & 0 & 106 & 2,334 & 934 & \multirow{2}{*}{$0 \%$} \\
\hline & & Advanced & 78 & 65 & 275 & 1060 & 218 & 30 & 149 & 275 & 67 & 0 & 106 & 2,323 & 929 & \\
\hline \multirow{2}{*}{$3 \mathrm{~A}$} & \multirow{2}{*}{ Atlanta } & Baseline & 78 & 65 & 275 & 1060 & 218 & 30 & 149 & 221 & 193 & 0 & 144 & 2,432 & 973 & \multirow{2}{*}{$0 \%$} \\
\hline & & Advanced & 78 & 65 & 275 & 1060 & 218 & 30 & 149 & 221 & 187 & 0 & 144 & 2,426 & 970 & \\
\hline \multirow{2}{*}{ 3B-CA } & \multirow{2}{*}{ Los_Angeles } & Baseline & 78 & 65 & 275 & 1060 & 218 & 30 & 147 & 74 & 63 & 0 & 139 & 2,148 & 859 & \multirow{2}{*}{$0 \%$} \\
\hline & & Advanced & 78 & 65 & 275 & 1060 & 218 & 30 & 146 & 74 & 60 & 0 & 139 & 2,146 & 858 & \\
\hline \multirow{2}{*}{ 3B-other } & \multirow{2}{*}{ Las_Vegas } & Baseline & 78 & 65 & 275 & 1060 & 218 & 30 & 159 & 205 & 110 & 0 & 123 & 2,323 & 929 & \multirow{2}{*}{$0 \%$} \\
\hline & & Advanced & 78 & 65 & 275 & 1060 & 218 & 30 & 157 & 203 & 108 & 0 & 123 & 2,317 & 927 & \\
\hline \multirow{3}{*}{$3 \mathrm{C}$} & \multirow{2}{*}{ San_Francisco } & Baseline & 78 & 65 & 275 & 1060 & 218 & 30 & 144 & 24 & 171 & 0 & 159 & 2,223 & 889 & \multirow{2}{*}{$1 \%$} \\
\hline & & Advanced & 78 & 65 & 275 & 1060 & 218 & 30 & 145 & 24 & 157 & 0 & 159 & 2,210 & 884 & \\
\hline & \multirow{2}{*}{ Baltimore } & Baseline & 78 & 65 & 275 & 1060 & 218 & 30 & 144 & 171 & 351 & 0 & 161 & 2,553 & 1021 & \multirow{2}{*}{$1 \%$} \\
\hline $4 \mathrm{~A}$ & & Advanced & 78 & 65 & 275 & 1060 & 218 & 30 & 143 & 171 & 336 & 0 & 161 & 2,537 & 1015 & \\
\hline $4 \mathrm{~B}$ & Albuguraue & Baseline & 78 & 65 & 275 & 1060 & 218 & 30 & 174 & 101 & 204 & 0 & 158 & 2,363 & 945 & $1 \%$ \\
\hline $4 \mathrm{~B}$ & Alouquerque & Advanced & 78 & 65 & 275 & 1060 & 218 & 30 & 171 & 100 & 196 & 0 & 158 & 2,350 & 940 & $1 \%$ \\
\hline$A C$ & Senttlo & Baseline & 78 & 64 & 275 & 1060 & 218 & 30 & 143 & 29 & 287 & 0 & 171 & 2,356 & 943 & \\
\hline $4 c$ & Seature & Advanced & 78 & 64 & 275 & 1060 & 218 & 30 & 144 & 29 & 273 & 0 & 171 & 2,343 & 937 & $1 \%$ \\
\hline & & Baseline & 78 & 65 & 275 & 1060 & 218 & 30 & 145 & 107 & 505 & 0 & 177 & 2,660 & 1064 & \\
\hline $5 \mathrm{~A}$ & Chicago & Advanced & 78 & 65 & 275 & 1060 & 218 & 30 & 143 & 107 & 483 & 0 & 177 & 2,636 & 1054 & $1 \%$ \\
\hline $5 \mathrm{~B}$ & & Baseline & 78 & 64 & 275 & 1060 & 218 & 30 & 173 & 70 & 322 & 0 & 177 & 2,467 & 987 & $1 \%$ \\
\hline ГВ & Denver & Advanced & 78 & 64 & 275 & 1060 & 218 & 30 & 169 & 69 & 308 & 0 & 177 & 2,448 & 979 & $1 \%$ \\
\hline $6 \mathrm{~A}$ & Minneanolis & Baseline & 78 & 64 & 275 & 1060 & 218 & 30 & 145 & 94 & 694 & 0 & 191 & 2,849 & 1140 & $1 \%$ \\
\hline $\mathrm{OA}$ & Mimmeapois & Advanced & 78 & 64 & 275 & 1060 & 218 & 30 & 144 & 95 & 657 & 0 & 191 & 2,813 & 1125 & 170 \\
\hline $6 \mathrm{~B}$ & Helena & Baseline & 78 & 64 & 275 & 1060 & 218 & 30 & 161 & 43 & 513 & 0 & 193 & 2,636 & 1054 & $1 \%$ \\
\hline OD & netena & Advanced & 78 & 64 & 275 & 1060 & 218 & 30 & 160 & 43 & 482 & 0 & 193 & 2,603 & 1041 & 170 \\
\hline 7 & Duluth & Baseline & 78 & 64 & 275 & 1060 & 218 & 30 & 147 & 34 & 859 & 0 & 213 & 2,980 & 1192 & $2 \%$ \\
\hline 1 & Duiutn & Advanced & 78 & 64 & 275 & 1060 & 218 & 30 & 146 & 35 & 811 & 0 & 213 & 2,930 & 1172 & $2 \%$ \\
\hline 8 & EFirhanks & Baseline & 78 & 64 & 275 & 1060 & 218 & 30 & 141 & 15 & 1410 & 0 & 241 & 3,532 & 1413 & 10 \\
\hline 0 & räroanins & Advanced & 78 & 64 & 275 & 1060 & 218 & 30 & 141 & 15 & 1383 & 0 & 241 & 3,505 & 1402 & $1 \%$ \\
\hline
\end{tabular}


Table 5.7. Energy Cost Savings Results for the Building Envelope EEM Package

\begin{tabular}{|c|c|c|c|c|c|c|c|c|}
\hline Climate Zone & City & $\begin{array}{c}\text { Electricity } \\
\text { Savings, } \\
\text { kWh }\end{array}$ & $\begin{array}{c}\text { Natural Gas } \\
\text { Savings, } \\
\text { therms }\end{array}$ & $\begin{array}{l}\text { Electricity } \\
\text { Cost } \\
\text { Savings }\end{array}$ & $\begin{array}{c}\text { Natural Gas } \\
\text { Cost } \\
\text { Savings }\end{array}$ & $\begin{array}{l}\text { Total Cost } \\
\text { Savings }\end{array}$ & $\begin{array}{c}\text { Baseline } \\
\text { Energy Cost }\end{array}$ & $\begin{array}{l}\text { Energy Cost } \\
\% \text { Savings }\end{array}$ \\
\hline$\overline{1 \mathrm{~A}}$ & Miami & 122 & 6 & $\$ 11$ & $\$ 7$ & $\$ 19$ & $\$ 48,016$ & $0 \%$ \\
\hline $2 \mathrm{~A}$ & Houston & 97 & 90 & $\$ 9$ & $\$ 105$ & $\$ 114$ & $\$ 46,158$ & $0 \%$ \\
\hline $2 \mathrm{~B}$ & Phoenix & 1317 & 69 & $\$ 124$ & $\$ 80$ & $\$ 204$ & $\$ 44,489$ & $0 \%$ \\
\hline $3 \mathrm{~A}$ & Atlanta & 64 & 56 & $\$ 6$ & $\$ 65$ & $\$ 71$ & $\$ 44,695$ & $0 \%$ \\
\hline 3B-CA & Los Angeles & 56 & 24 & $\$ 5$ & $\$ 28$ & $\$ 33$ & $\$ 39,026$ & $0 \%$ \\
\hline 3B-other & Las Vegas & 1075 & 26 & $\$ 101$ & $\$ 30$ & $\$ 131$ & $\$ 43,331$ & $0 \%$ \\
\hline $3 \mathrm{C}$ & San Francisco & -236 & 136 & $(\$ 22)$ & $\$ 158$ & $\$ 136$ & $\$ 39,048$ & $0 \%$ \\
\hline $4 \mathrm{~A}$ & Baltimore & 408 & 148 & $\$ 38$ & $\$ 172$ & $\$ 210$ & $\$ 45,219$ & $0 \%$ \\
\hline $4 \mathrm{~B}$ & Albuquerque & 1564 & 76 & $\$ 147$ & $\$ 89$ & $\$ 235$ & $\$ 42,387$ & $1 \%$ \\
\hline $4 \mathrm{C}$ & Seattle & -81 & 141 & $(\$ 8)$ & $\$ 164$ & $\$ 156$ & $\$ 40,674$ & $0 \%$ \\
\hline $5 \mathrm{~A}$ & Chicago & 575 & 222 & $\$ 54$ & $\$ 257$ & $\$ 311$ & $\$ 45,451$ & $1 \%$ \\
\hline $5 B$ & Denver & 1411 & 141 & $\$ 133$ & $\$ 163$ & $\$ 296$ & $\$ 43,068$ & $1 \%$ \\
\hline $6 \mathrm{~A}$ & Minneapolis & -211 & 367 & $(\$ 20)$ & $\$ 425$ & $\$ 406$ & $\$ 47,434$ & $1 \%$ \\
\hline $6 \mathrm{~B}$ & Helena & 236 & 318 & $\$ 22$ & $\$ 369$ & $\$ 391$ & $\$ 44,411$ & $1 \%$ \\
\hline 7 & Duluth & 414 & 486 & $\$ 39$ & $\$ 564$ & $\$ 603$ & $\$ 48,048$ & $1 \%$ \\
\hline 8 & Fairbanks & 81 & 272 & $\$ 8$ & $\$ 315$ & $\$ 323$ & $\$ 54,051$ & $1 \%$ \\
\hline
\end{tabular}


Table 5.8. Energy Savings Results for the Lighting and Daylighting EEM Package

\begin{tabular}{|c|c|c|c|c|c|c|c|c|c|c|c|c|c|c|c|c|}
\hline $\begin{array}{l}\text { Climate } \\
\text { Zone }\end{array}$ & City & Model & $\begin{array}{l}\text { Interior } \\
\text { Lighting }\end{array}$ & $\begin{array}{l}\text { Exterior } \\
\text { Lighting }\end{array}$ & $\begin{array}{l}\text { Cooking } \\
\text { Elec }\end{array}$ & $\begin{array}{c}\text { Cooking } \\
\text { gas }\end{array}$ & Refrigeration & $\begin{array}{c}\text { Kitchen } \\
\text { Exhaust } \\
\text { Fan }\end{array}$ & $\begin{array}{l}\text { Supply } \\
\text { Fan }\end{array}$ & Cooling & Heating & $\begin{array}{c}\text { Heat } \\
\text { Recovery }\end{array}$ & SWH & Total & EUI & $\begin{array}{l}\text { Energy } \\
\text { Saving }\end{array}$ \\
\hline & & & MMBtu & MMBtu & MMBtu & MMBtu & MMBtu & MMBtu & MMBtu & MMBtu & MMBtu & MMBtu & MMBtu & MMBtu & $\mathrm{kBtu} / \mathrm{sf}$ & $\%$ \\
\hline \multirow{3}{*}{$1 \mathrm{~A}$} & \multirow{2}{*}{ Miami } & Baseline & 78 & 65 & 275 & 1,060 & 218 & 30 & 148 & 439 & 10 & 0 & 97 & 2,420 & 968 & \multirow{2}{*}{$3 \%$} \\
\hline & & Advanced & 37 & 33 & 275 & 1,060 & 218 & 30 & 147 & 430 & 10 & 0 & 97 & 2,336 & 934 & \\
\hline & \multirow{2}{*}{ Houston } & Baseline & 78 & 65 & 275 & 1,060 & 218 & 30 & 144 & 325 & 109 & 0 & 120 & 2,423 & 969 & \multirow{2}{*}{$3 \%$} \\
\hline $2 \mathrm{~A}$ & & Advanced & 37 & 33 & 275 & 1,060 & 218 & 30 & 142 & 317 & 113 & 0 & 120 & 2,344 & 938 & \\
\hline \multirow{2}{*}{$2 \mathrm{~B}$} & \multirow{2}{*}{ Phoenix } & Baseline & 78 & 65 & 275 & 1,060 & 218 & 30 & 151 & 277 & 73 & 0 & 106 & 2,334 & 934 & \multirow{2}{*}{$3 \%$} \\
\hline & & Advanced & 37 & 33 & 275 & 1,060 & 218 & 30 & 148 & 272 & 77 & 0 & 106 & 2,255 & 902 & \\
\hline \multirow{3}{*}{$3 \mathrm{~A}$} & \multirow{2}{*}{ Atlanta } & Baseline & 78 & 65 & 275 & 1,060 & 218 & 30 & 149 & 221 & 193 & 0 & 144 & 2,432 & 973 & \multirow{2}{*}{$3 \%$} \\
\hline & & Advanced & 37 & 33 & 275 & 1,060 & 218 & 30 & 147 & 214 & 201 & 0 & 144 & 2,358 & 943 & \\
\hline & \multirow{2}{*}{ Los_Angeles } & Baseline & 78 & 65 & 275 & 1,060 & 218 & 30 & 147 & 74 & 63 & 0 & 139 & 2,148 & 859 & \multirow{2}{*}{$3 \%$} \\
\hline 3B-CA & & Advanced & 37 & 33 & 275 & 1,060 & 218 & 30 & 145 & 70 & 68 & 0 & 139 & 2,075 & 830 & \\
\hline \multirow{2}{*}{ 3B-other } & \multirow{2}{*}{ Las_Vegas } & Baseline & 78 & 65 & 275 & 1,060 & 218 & 30 & 159 & 205 & 110 & 0 & 123 & 2,323 & 929 & \multirow{2}{*}{$3 \%$} \\
\hline & & Advanced & 37 & 33 & 275 & 1,060 & 218 & 30 & 154 & 200 & 117 & 0 & 123 & 2,247 & 899 & \\
\hline \multirow{3}{*}{$3 \mathrm{C}$} & \multirow{2}{*}{ San_Francisco } & Baseline & 78 & 65 & 275 & 1,060 & 218 & 30 & 144 & 24 & 171 & 0 & 159 & 2,223 & 889 & \multirow{2}{*}{$3 \%$} \\
\hline & & Advanced & 37 & 33 & 275 & 1,060 & 218 & 30 & 141 & 23 & 180 & 0 & 159 & 2,154 & 862 & \\
\hline & \multirow{2}{*}{ Baltimore } & Baseline & 78 & 65 & 275 & 1,060 & 218 & 30 & 144 & 171 & 351 & 0 & 161 & 2,553 & 1,021 & \multirow{2}{*}{$3 \%$} \\
\hline $4 \mathrm{~A}$ & & Advanced & 37 & 33 & 275 & 1,060 & 218 & 30 & 142 & 165 & 364 & 0 & 161 & 2,485 & 994 & \\
\hline & & Baseline & 78 & 65 & 275 & 1,060 & 218 & 30 & 174 & 101 & 204 & 0 & 158 & 2,363 & 945 & \\
\hline 4B & Albuquerque & Advanced & 37 & 33 & 275 & 1,060 & 218 & 30 & 169 & 98 & 215 & 0 & 158 & 2,292 & 917 & $3 \%$ \\
\hline & & Baseline & 78 & 64 & 275 & 1,060 & 218 & 30 & 143 & 29 & 287 & 0 & 171 & 2,356 & 943 & \\
\hline $4 \mathrm{C}$ & Seattle & Advanced & 37 & 33 & 275 & 1,060 & 218 & 30 & 141 & 28 & 301 & 0 & 171 & 2,294 & 917 & $3 \%$ \\
\hline & & Baseline & 78 & 65 & 275 & 1,060 & 218 & 30 & 145 & 107 & 505 & 0 & 177 & 2,660 & 1,064 & \\
\hline $5 \mathrm{~A}$ & Chicago & Advanced & 37 & 33 & 275 & 1,060 & 218 & 30 & 142 & 104 & 521 & 0 & 177 & 2,596 & 1,039 & $2 \%$ \\
\hline & & Baseline & 78 & 64 & 275 & 1,060 & 218 & 30 & 173 & 70 & 322 & 0 & 177 & 2,467 & 987 & \\
\hline $5 \mathrm{~B}$ & Denver & Advanced & 37 & 33 & 275 & 1,060 & 218 & 30 & 167 & 67 & 337 & 0 & 177 & 2,400 & 960 & $3 \%$ \\
\hline & & Baseline & 78 & 64 & 275 & 1,060 & 218 & 30 & 145 & 94 & 694 & 0 & 191 & 2,849 & 1,140 & \\
\hline $6 \mathrm{~A}$ & Minneapolis & Advanced & 37 & 33 & 275 & 1,060 & 218 & 30 & 142 & 91 & 710 & 0 & 191 & 2,787 & 1,115 & $2 \%$ \\
\hline & & Baseline & 78 & 64 & 275 & 1,060 & 218 & 30 & 161 & 43 & 513 & 0 & 193 & 2,636 & 1,054 & $2 \%$ \\
\hline $6 \mathrm{~B}$ & Helena & Advanced & 37 & 33 & 275 & 1,060 & 218 & 30 & 156 & 41 & 532 & 0 & 193 & 2,574 & 1,030 & $2 \%$ \\
\hline & & Baseline & 78 & 64 & 275 & 1,060 & 218 & 30 & 147 & 34 & 859 & 0 & 213 & 2,980 & 1,192 & \\
\hline 7 & Duluth & Advanced & 37 & 33 & 275 & 1,060 & 218 & 30 & 144 & 33 & 880 & 0 & 213 & 2,922 & 1,169 & $2 \%$ \\
\hline 8 & & Baseline & 78 & 64 & 275 & 1,060 & 218 & 30 & 141 & 15 & 1,410 & 0 & 241 & 3,532 & 1,413 & $1 \%$ \\
\hline 8 & Faurbanks & Advanced & 38 & 33 & 275 & 1,060 & 218 & 30 & 139 & 15 & 1,432 & 0 & 241 & 3,480 & 1,392 & $1 \%$ \\
\hline
\end{tabular}


Table 5.9. Energy Cost Savings Results for the Lighting and Daylighting EEM Package

\begin{tabular}{|c|c|c|c|c|c|c|c|c|}
\hline Zone & City & $\begin{array}{c}\text { Electricity } \\
\text { Savings, } \\
\text { kWh }\end{array}$ & $\begin{array}{c}\text { Natural Gas } \\
\text { Savings, } \\
\text { therms }\end{array}$ & $\begin{array}{c}\text { Electricity } \\
\text { Cost } \\
\text { Savings }\end{array}$ & $\begin{array}{c}\text { Natural Gas } \\
\text { Cost } \\
\text { Savings }\end{array}$ & $\begin{array}{c}\text { Total Cost } \\
\text { Savings } \\
\end{array}$ & $\begin{array}{c}\text { Baseline } \\
\text { Energy } \\
\text { Cost }\end{array}$ & $\begin{array}{l}\text { Energy } \\
\text { Cost \% } \\
\text { Savings } \\
\end{array}$ \\
\hline $1 \mathrm{~A}$ & Miami & 24,634 & -6 & $\$ 2,313$ & $(\$ 6)$ & $\$ 2,307$ & $\$ 48,016$ & $5 \%$ \\
\hline $2 \mathrm{~A}$ & Houston & 24,284 & -36 & $\$ 2,280$ & $(\$ 41)$ & $\$ 2,239$ & $\$ 46,158$ & $5 \%$ \\
\hline $2 \mathrm{~B}$ & Phoenix & 24,156 & -31 & $\$ 2,268$ & $(\$ 35)$ & $\$ 2,233$ & $\$ 44,489$ & $5 \%$ \\
\hline $3 \mathrm{~A}$ & Atlanta & 24,000 & -79 & $\$ 2,254$ & $(\$ 92)$ & $\$ 2,162$ & $\$ 44,695$ & $5 \%$ \\
\hline $3 \mathrm{~B}-\mathrm{CA}$ & Los Angeles & 23,039 & -57 & $\$ 2,163$ & $(\$ 66)$ & $\$ 2,097$ & $\$ 39,026$ & $5 \%$ \\
\hline 3B-other & Las Vegas & 24,212 & -64 & $\$ 2,273$ & $(\$ 75)$ & $\$ 2,199$ & $\$ 43,331$ & $5 \%$ \\
\hline $3 \mathrm{C}$ & San Francisco & 22,675 & -87 & $\$ 2,129$ & $(\$ 100)$ & $\$ 2,029$ & $\$ 39,048$ & $5 \%$ \\
\hline $4 \mathrm{~A}$ & Baltimore & 23,700 & -126 & $\$ 2,225$ & $(\$ 146)$ & $\$ 2,080$ & $\$ 45,219$ & $5 \%$ \\
\hline $4 \mathrm{~B}$ & Albuquerque & 24,037 & -113 & $\$ 2,257$ & $(\$ 131)$ & $\$ 2,127$ & $\$ 42,387$ & $5 \%$ \\
\hline $4 \mathrm{C}$ & Seattle & 22,384 & -135 & $\$ 2,102$ & $(\$ 156)$ & $\$ 1,946$ & $\$ 40,674$ & $5 \%$ \\
\hline $5 \mathrm{~A}$ & Chicago & 23,081 & -155 & $\$ 2,167$ & $(\$ 179)$ & $\$ 1,988$ & $\$ 45,451$ & $4 \%$ \\
\hline $5 \mathrm{~B}$ & Denver & 23,870 & -146 & $\$ 2,241$ & $(\$ 170)$ & $\$ 2,072$ & $\$ 43,068$ & $5 \%$ \\
\hline $6 \mathrm{~A}$ & Minneapolis & 22,973 & -163 & $\$ 2,157$ & $(\$ 189)$ & $\$ 1,968$ & $\$ 47,434$ & $4 \%$ \\
\hline $6 \mathrm{~B}$ & Helena & 23,478 & -184 & $\$ 2,205$ & $(\$ 213)$ & $\$ 1,991$ & $\$ 44,411$ & $4 \%$ \\
\hline 7 & Duluth & 22,973 & -207 & $\$ 2,157$ & $(\$ 240)$ & $\$ 1,917$ & $\$ 48,048$ & $4 \%$ \\
\hline 8 & Fairbanks & 21,953 & -221 & $\$ 2,061$ & $(\$ 256)$ & $\$ 1,805$ & $\$ 54,051$ & $3 \%$ \\
\hline
\end{tabular}


Table 5.10. Energy Savings Results for the Commercial Kitchen Appliance EEM Package

\begin{tabular}{|c|c|c|c|c|c|c|c|c|c|c|c|c|c|c|c|c|}
\hline $\begin{array}{l}\text { Climate } \\
\text { Zone }\end{array}$ & City & Model & $\begin{array}{l}\text { Interior } \\
\text { Lighting }\end{array}$ & $\begin{array}{l}\text { Exterior } \\
\text { Lighting }\end{array}$ & $\begin{array}{c}\text { Cooking } \\
\text { Elec }\end{array}$ & $\begin{array}{c}\text { Cooking } \\
\text { Gas }\end{array}$ & Refrigeration & $\begin{array}{c}\text { Kitchen } \\
\text { Exhaust } \\
\text { Fan }\end{array}$ & $\begin{array}{l}\text { Supply } \\
\text { Fan }\end{array}$ & Cooling & Heating & $\begin{array}{c}\text { Heat } \\
\text { Recovery }\end{array}$ & SWH & Total & EUI & $\begin{array}{l}\text { Energy } \\
\text { Saving }\end{array}$ \\
\hline & & & MMBtu & MMBtu & MMBtu & MMBtu & MMBtu & MMBtu & MMBtu & MMBtu & MMBtu & MMBtu & MMBtu & MMBtu & $\mathrm{kBtu} / \mathrm{sf}$ & $\%$ \\
\hline & Miami & Baseline & 78 & 65 & 275 & 1,060 & 218 & 30 & 148 & 439 & 10 & 0 & 97 & 2,420 & 968 & \\
\hline IA & Miamı & Advanced & 78 & 65 & 207 & 618 & 165 & 30 & 99 & 275 & 12 & 0 & 97 & 1,644 & 658 & $32 \%$ \\
\hline & Houston & Baseline & 78 & 65 & 275 & 1,060 & 218 & 30 & 144 & 325 & 109 & 0 & 120 & 2,423 & 969 & \\
\hline $2 \mathrm{~A}$ & Houston & Advanced & 78 & 65 & 207 & 618 & 165 & 30 & 96 & 190 & 154 & 0 & 120 & 1,722 & 689 & $29 \%$ \\
\hline & & Baseline & 78 & 65 & 275 & 1,060 & 218 & 30 & 151 & 277 & 73 & 0 & 106 & 2,334 & 934 & \\
\hline $2 \mathrm{~B}$ & Phoenix & Advanced & 78 & 65 & 207 & 618 & 165 & 30 & 99 & 184 & 102 & 0 & 106 & 1,654 & 661 & $29 \%$ \\
\hline & & Baseline & 78 & 65 & 275 & 1,060 & 218 & 30 & 149 & 221 & 193 & 0 & 144 & 2,432 & 973 & \\
\hline $3 \mathrm{~A}$ & Atlanta & Advanced & 78 & 65 & 207 & 618 & 165 & 30 & 100 & 119 & 274 & 0 & 144 & 1,799 & 719 & $26 \%$ \\
\hline & & Baseline & 78 & 65 & 275 & 1,060 & 218 & 30 & 147 & 74 & 63 & 0 & 139 & 2,148 & 859 & \\
\hline 3B-CA & Los_Angeles & Advanced & 78 & 65 & 207 & 618 & 165 & 30 & 97 & 45 & 82 & 0 & 139 & 1,524 & 610 & $29 \%$ \\
\hline & & Baseline & 78 & 65 & 275 & 1,060 & 218 & 30 & 159 & 205 & 110 & 0 & 123 & 2,323 & 929 & \\
\hline 3B-other & r Las_Vegas & Advanced & 78 & 65 & 207 & 618 & 165 & 30 & 105 & 141 & 161 & 0 & 123 & 1,692 & 677 & $27 \%$ \\
\hline & & Baseline & 78 & 65 & 275 & 1,060 & 218 & 30 & 144 & 24 & 171 & 0 & 159 & 2,223 & 889 & \\
\hline $3 \mathrm{C}$ & San_Francisco & Advanced & 78 & 65 & 207 & 618 & 165 & 30 & 96 & 14 & 235 & 0 & 159 & 1,665 & 666 & $25 \%$ \\
\hline & & Baseline & 78 & 65 & 275 & 1,060 & 218 & 30 & 144 & 171 & 351 & 0 & 161 & 2,553 & 1,021 & \\
\hline $4 \mathrm{~A}$ & Baltimore & Advanced & 78 & 65 & 207 & 618 & 165 & 30 & 98 & 92 & 490 & 0 & 161 & 2,003 & 801 & $22 \%$ \\
\hline i & & Baseline & 78 & 65 & 275 & 1,060 & 218 & 30 & 174 & 101 & 204 & 0 & 158 & 2,363 & 945 & \\
\hline 4B & Albuquerque & Advanced & 78 & 65 & 207 & 618 & 165 & 30 & 116 & 70 & 303 & 0 & 158 & 1,809 & 723 & $23 \%$ \\
\hline & & Baseline & 78 & 64 & 275 & 1,060 & 218 & 30 & 143 & 29 & 287 & 0 & 171 & 2,356 & 943 & \\
\hline $4 \mathrm{C}$ & Seattle & Advanced & 78 & 64 & 207 & 618 & 165 & 30 & 97 & 18 & 432 & 0 & 171 & 1,880 & 752 & $20 \%$ \\
\hline & & Baseline & 78 & 65 & 275 & 1,060 & 218 & 30 & 145 & 107 & 505 & 0 & 177 & 2,660 & 1,064 & \\
\hline $5 \mathrm{~A}$ & Chicago & Advanced & 78 & 65 & 207 & 618 & 165 & 30 & 99 & 65 & 676 & 0 & 177 & 2,179 & 872 & $18 \%$ \\
\hline & & Baseline & 78 & 64 & 275 & 1,060 & 218 & 30 & 173 & 70 & 322 & 0 & 177 & 2,467 & 987 & \\
\hline $5 \mathrm{~B}$ & Denver & Advanced & 78 & 64 & 207 & 618 & 165 & 30 & 115 & 47 & 458 & 0 & 177 & 1,958 & 783 & $21 \%$ \\
\hline & & Baseline & 78 & 64 & 275 & 1,060 & 218 & 30 & 145 & 94 & 694 & 0 & 191 & 2,849 & 1,140 & \\
\hline $6 \mathrm{~A}$ & Minneapolis & Advanced & 78 & 64 & 207 & 618 & 165 & 30 & 99 & 57 & 877 & 0 & 191 & 2,386 & 954 & $16 \%$ \\
\hline & & Baseline & 78 & 64 & 275 & 1,060 & 218 & 30 & 161 & 43 & 513 & 0 & 193 & 2,636 & 1,054 & $17 \%$ \\
\hline $6 \mathrm{~B}$ & Helena & Advanced & 78 & 64 & 207 & 618 & 165 & 30 & 108 & 28 & 695 & 0 & 193 & 2,185 & 874 & $17 \%$ \\
\hline & & Baseline & 78 & 64 & 275 & 1,060 & 218 & 30 & 147 & 34 & 859 & 0 & 213 & 2,980 & 1,192 & \\
\hline & 7 Duluth & Advanced & 78 & 64 & 207 & 618 & 165 & 30 & 100 & 23 & 1,082 & 0 & 213 & 2,580 & 1,032 & $13 \%$ \\
\hline & & Baseline & 78 & 64 & 275 & 1,060 & 218 & 30 & 141 & 15 & 1,410 & 0 & 241 & 3,532 & 1,413 & \\
\hline & 8 Fairbanks & Advanced & 78 & 64 & 207 & 618 & 165 & 30 & 97 & 9 & 1,664 & 0 & 241 & 3,171 & 1,268 & $10 \%$ \\
\hline
\end{tabular}


Table 5.11. Energy Cost Savings Results for the Commercial Kitchen Appliance EEM Package

\begin{tabular}{llcc|ccc|cc}
\hline Zone & City & $\begin{array}{c}\text { Electricity } \\
\text { Savings, } \\
\mathrm{kWh}\end{array}$ & $\begin{array}{c}\text { Natural } \\
\text { Gas } \\
\text { Savings, } \\
\text { therms }\end{array}$ & $\begin{array}{c}\text { Electricity } \\
\text { Cost } \\
\text { Savings }\end{array}$ & $\begin{array}{c}\text { Natural } \\
\text { Gas Cost } \\
\text { Savings }\end{array}$ & $\begin{array}{c}\text { Total Cost } \\
\text { Savings }\end{array}$ & $\begin{array}{c}\text { Baseline } \\
\text { Energy } \\
\text { Cost }\end{array}$ & $\begin{array}{c}\text { Energy } \\
\text { Cost } \% \\
\text { Savings }\end{array}$ \\
\hline 1A & Miami & 98,421 & 4,400 & $\$ 9,242$ & $\$ 5,104$ & $\$ 14,345$ & $\$ 48,016$ & $30 \%$ \\
2A & Houston & 89,045 & 3,978 & $\$ 8,361$ & $\$ 4,614$ & $\$ 12,975$ & $\$ 46,158$ & $28 \%$ \\
2B & Phoenix & 78,163 & 4,137 & $\$ 7,340$ & $\$ 4,798$ & $\$ 12,138$ & $\$ 44,489$ & $27 \%$ \\
3A & Atlanta & 79,791 & 3,611 & $\$ 7,492$ & $\$ 4,189$ & $\$ 11,682$ & $\$ 44,695$ & $26 \%$ \\
3B-CA & Los Angeles & 58,847 & 4,234 & $\$ 5,526$ & $\$ 4,912$ & $\$ 10,438$ & $\$ 39,026$ & $27 \%$ \\
3B-other & Las Vegas & 69,948 & 3,922 & $\$ 6,568$ & $\$ 4,550$ & $\$ 11,118$ & $\$ 43,331$ & $26 \%$ \\
3C & San Francisco & 52,604 & 3,781 & $\$ 4,940$ & $\$ 4,386$ & $\$ 9,325$ & $\$ 39,048$ & $24 \%$ \\
4A & Baltimore & 72,151 & 3,038 & $\$ 6,775$ & $\$ 3,524$ & $\$ 10,299$ & $\$ 45,219$ & $23 \%$ \\
4B & Albuquerque & 61,930 & 3,430 & $\$ 5,815$ & $\$ 3,979$ & $\$ 9,794$ & $\$ 42,387$ & $23 \%$ \\
4C & Seattle & 52,268 & 2,982 & $\$ 4,908$ & $\$ 3,459$ & $\$ 8,367$ & $\$ 40,674$ & $21 \%$ \\
5A & Chicago & 61,228 & 2,716 & $\$ 5,749$ & $\$ 3,150$ & $\$ 8,900$ & $\$ 45,451$ & $20 \%$ \\
5B & Denver & 59,069 & 3,072 & $\$ 5,547$ & $\$ 3,564$ & $\$ 9,110$ & $\$ 43,068$ & $21 \%$ \\
6A & Minneapolis & 59,711 & 2,592 & $\$ 5,607$ & $\$ 3,007$ & $\$ 8,614$ & $\$ 47,434$ & $18 \%$ \\
6B & Helena & 55,582 & 2,611 & $\$ 5,219$ & $\$ 3,029$ & $\$ 8,248$ & $\$ 44,411$ & $19 \%$ \\
7 & Duluth & 52,685 & 2,198 & $\$ 4,947$ & $\$ 2,550$ & $\$ 7,497$ & $\$ 48,048$ & $16 \%$ \\
8 & Fairbanks & 50,504 & 1,889 & $\$ 4,742$ & $\$ 2,191$ & $\$ 6,934$ & $\$ 54,051$ & $13 \%$ \\
\hline
\end{tabular}


Table 5.12. Energy Savings Results for the Mechanical System EEM Package

\begin{tabular}{|c|c|c|c|c|c|c|c|c|c|c|c|c|c|c|c|c|}
\hline $\begin{array}{l}\text { Climate } \\
\text { Zone }\end{array}$ & City & Model & $\begin{array}{l}\text { Interior } \\
\text { Lighting }\end{array}$ & $\begin{array}{l}\text { Exterior } \\
\text { Lighting }\end{array}$ & $\begin{array}{c}\text { Cooking } \\
\text { Elec }\end{array}$ & $\begin{array}{c}\text { Cooking } \\
\text { Gas }\end{array}$ & Refrigeration & $\begin{array}{c}\text { Kitchen } \\
\text { Exhaust } \\
\text { Fan }\end{array}$ & $\begin{array}{l}\text { Supply } \\
\text { Fan }\end{array}$ & Cooling & Heating & $\begin{array}{c}\text { Heat } \\
\text { Recovery }\end{array}$ & SWH & Total & EUI & $\begin{array}{l}\text { Energy } \\
\text { Saving }\end{array}$ \\
\hline & & & MMBtu & MMBtu & MMBtu & MMBtu & MMBtu & MMBtu & MMBtu & MMBtu & MMBtu & MMBtu & MMBtu & MMBtu & $\mathrm{kBtu} / \mathrm{sf}$ & $\%$ \\
\hline $1 \mathrm{~A}$ & Miami & Baseline & 78 & 65 & 275 & 1,060 & 218 & 30 & 148 & 439 & 10 & 0 & 97 & 2,420 & 968 & $10 \%$ \\
\hline IA & Miamı & Advanced & 78 & 65 & 275 & 1,060 & 218 & 5 & 126 & 324 & 2 & 0 & 34 & 2,187 & 875 & $10 \%$ \\
\hline & & Baseline & 78 & 65 & 275 & 1,060 & 218 & 30 & 144 & 325 & 109 & 0 & 120 & 2,423 & 969 & \\
\hline $2 \mathrm{~A}$ & Houston & Advanced & 78 & 65 & 275 & 1,060 & 218 & 5 & 121 & 207 & 29 & 0 & 54 & 2,113 & 845 & $13 \%$ \\
\hline & & Baseline & 78 & 65 & 275 & 1,060 & 218 & 30 & 151 & 277 & 73 & 0 & 106 & 2,334 & 934 & \\
\hline $2 \mathrm{~B}$ & Phoenix & Advanced & 78 & 65 & 275 & 1,060 & 218 & 5 & 131 & 189 & 19 & 0 & 44 & 2,085 & 834 & $11 \%$ \\
\hline & & Baseline & 78 & 65 & 275 & 1,060 & 218 & 30 & 149 & 221 & 193 & 0 & 144 & 2,432 & 973 & \\
\hline $3 \mathrm{~A}$ & Atlanta & Advanced & 78 & 65 & 275 & 1,060 & 218 & 5 & 129 & 133 & 45 & 0 & 73 & 2,081 & 833 & $14 \%$ \\
\hline & & Baseline & 78 & 65 & 275 & 1,060 & 218 & 30 & 147 & 74 & 63 & 0 & 139 & 2,148 & 859 & \\
\hline 3B-CA & Los Angeles & Advanced & 78 & 65 & 275 & 1,060 & 218 & 5 & 124 & 67 & 10 & 0 & 70 & 1,973 & 789 & $8 \%$ \\
\hline & & Baseline & 78 & 65 & 275 & 1,060 & 218 & 30 & 159 & 205 & 110 & 0 & 123 & 2,323 & 929 & \\
\hline 3B-other & Las Vegas & Advanced & 78 & 65 & 275 & 1,060 & 218 & 5 & 138 & 143 & 24 & 0 & 57 & 2,063 & 825 & $11 \%$ \\
\hline & & Baseline & 78 & 65 & 275 & 1,060 & 218 & 30 & 144 & 24 & 171 & 0 & 159 & 2,223 & 889 & \\
\hline $3 \mathrm{C}$ & San Francisco & Advanced & 78 & 65 & 275 & 1,060 & 218 & 5 & 123 & 23 & 38 & 0 & 86 & 1,971 & 788 & $11 \%$ \\
\hline u & & Baseline & 78 & 65 & 275 & 1,060 & 218 & 30 & 144 & 171 & 351 & 0 & 161 & 2,553 & 1,021 & \\
\hline $4 \mathrm{~A}$ & Baltimore & Advanced & 78 & 65 & 275 & 1,060 & 218 & 5 & 125 & 103 & 81 & 0 & 88 & 2,099 & 840 & $18 \%$ \\
\hline & & Baseline & 78 & 65 & 275 & 1,060 & 218 & 30 & 174 & 101 & 204 & 0 & 158 & 2,363 & 945 & \\
\hline 4B & Albuquerque & Advanced & 78 & 65 & 275 & 1,060 & 218 & 5 & 149 & 88 & 48 & 0 & 86 & 2,071 & 828 & $12 \%$ \\
\hline & & Baseline & 78 & 64 & 275 & 1,060 & 218 & 30 & 143 & 29 & 287 & 0 & 171 & 2,356 & 943 & \\
\hline $4 \mathrm{C}$ & Seattle & Advanced & 78 & 64 & 275 & 1,060 & 218 & 5 & 125 & 27 & 69 & 0 & 97 & 2,018 & 807 & $14 \%$ \\
\hline & & Baseline & 78 & 65 & 275 & 1,060 & 218 & 30 & 145 & 107 & 505 & 0 & 177 & 2,660 & 1,064 & \\
\hline $5 \mathrm{~A}$ & Chicago & Advanced & 78 & 65 & 275 & 1,060 & 218 & 5 & 171 & 89 & 82 & 1 & 102 & 2,146 & 859 & $19 \%$ \\
\hline & & Baseline & 78 & 64 & 275 & 1,060 & 218 & 30 & 173 & 70 & 322 & 0 & 177 & 2,467 & 987 & \\
\hline $5 \mathrm{~B}$ & Denver & Advanced & 78 & 64 & 275 & 1,060 & 218 & 5 & 147 & 61 & 76 & 0 & 101 & 2,087 & 835 & $15 \%$ \\
\hline & & Baseline & 78 & 64 & 275 & 1,060 & 218 & 30 & 145 & 94 & 694 & 0 & 191 & 2,849 & 1,140 & \\
\hline $6 \mathrm{~A}$ & Minneapolis & Advanced & 78 & 64 & 275 & 1,060 & 218 & 5 & 169 & 79 & 120 & 1 & 114 & 2,185 & 874 & $23 \%$ \\
\hline & & Baseline & 78 & 64 & 275 & 1,060 & 218 & 30 & 161 & 43 & 513 & 0 & 193 & 2,636 & 1,054 & \\
\hline $6 \mathrm{~B}$ & Helena & Advanced & 78 & 64 & 275 & 1,060 & 218 & 5 & 189 & 47 & 86 & 2 & 115 & 2,139 & 856 & $19 \%$ \\
\hline & & Baseline & 78 & 64 & 275 & 1,060 & 218 & 30 & 147 & 34 & 859 & 0 & 213 & 2,980 & 1,192 & $26 \%$ \\
\hline 7 & Duluth & Advanced & 78 & 64 & 275 & 1,060 & 218 & 5 & 170 & 39 & 151 & 2 & 132 & 2,195 & 878 & $26 \%$ \\
\hline & & Baseline & 78 & 64 & 275 & 1,060 & 218 & 30 & 141 & 15 & 1,410 & 0 & 241 & 3,532 & 1,413 & \\
\hline 8 & Fairbanks & Advanced & 78 & 64 & 275 & 1,060 & 218 & 5 & 164 & 23 & 280 & 2 & 161 & 2,331 & 932 & $34 \%$ \\
\hline
\end{tabular}


Table 5.13. Energy Cost Savings Results for the Mechanical System EEM Package

\begin{tabular}{llcc|ccc|cc}
\hline Zone & City & $\begin{array}{c}\text { Electricity } \\
\text { Savings, } \\
\mathrm{kWh}\end{array}$ & $\begin{array}{c}\text { Natural } \\
\text { Gas } \\
\text { Savings, } \\
\text { therms }\end{array}$ & $\begin{array}{c}\text { Electricity } \\
\text { Cost } \\
\text { Savings }\end{array}$ & $\begin{array}{c}\text { Natural } \\
\text { Gas Cost } \\
\text { Savings }\end{array}$ & $\begin{array}{c}\text { Total Cost } \\
\text { Savings }\end{array}$ & $\begin{array}{c}\text { Baseline } \\
\text { Energy } \\
\text { Cost }\end{array}$ & $\begin{array}{c}\text { Energy } \\
\text { Cost } \% \\
\text { Savings }\end{array}$ \\
\hline 1A & Miami & 47,537 & 702 & $\$ 4,464$ & $\$ 814$ & $\$ 5,278$ & $\$ 48,016$ & $11 \%$ \\
2A & Houston & 48,043 & 1,462 & $\$ 4,511$ & $\$ 1,696$ & $\$ 6,207$ & $\$ 46,158$ & $13 \%$ \\
2B & Phoenix & 38,747 & 1,171 & $\$ 3,638$ & $\$ 1,358$ & $\$ 4,996$ & $\$ 44,489$ & $11 \%$ \\
3A & Atlanta & 38,980 & 2,178 & $\$ 3,660$ & $\$ 2,526$ & $\$ 6,186$ & $\$ 44,695$ & $14 \%$ \\
3B-CA & Los Angeles & 15,785 & 1,216 & $\$ 1,482$ & $\$ 1,411$ & $\$ 2,893$ & $\$ 39,026$ & $7 \%$ \\
3B-other & Las Vegas & 31,401 & 1,531 & $\$ 2,949$ & $\$ 1,777$ & $\$ 4,725$ & $\$ 43,331$ & $11 \%$ \\
3C & San Francisco & 13,457 & 2,057 & $\$ 1,264$ & $\$ 2,386$ & $\$ 3,650$ & $\$ 39,048$ & $9 \%$ \\
4A & Baltimore & 32,646 & 3,426 & $\$ 3,065$ & $\$ 3,974$ & $\$ 7,039$ & $\$ 45,219$ & $16 \%$ \\
4B & Albuquerque & 18,661 & 2,286 & $\$ 1,752$ & $\$ 2,652$ & $\$ 4,404$ & $\$ 42,387$ & $10 \%$ \\
4C & Seattle & 13,405 & 2,930 & $\$ 1,259$ & $\$ 3,398$ & $\$ 4,657$ & $\$ 40,674$ & $11 \%$ \\
5A & Chicago & 4,742 & 4,985 & $\$ 445$ & $\$ 5,783$ & $\$ 6,228$ & $\$ 45,451$ & $14 \%$ \\
5B & Denver & 17,144 & 3,216 & $\$ 1,610$ & $\$ 3,731$ & $\$ 5,340$ & $\$ 43,068$ & $12 \%$ \\
6A & Minneapolis & 4,167 & 6,515 & $\$ 391$ & $\$ 7,558$ & $\$ 7,949$ & $\$ 47,434$ & $17 \%$ \\
6B & Helena & $-2,211$ & 5,058 & $(\$ 208)$ & $\$ 5,867$ & $\$ 5,659$ & $\$ 44,411$ & $13 \%$ \\
7 & Duluth & -933 & 7,894 & $(\$ 88)$ & $\$ 9,158$ & $\$ 9,070$ & $\$ 48,048$ & $19 \%$ \\
8 & Fairbanks & $-1,664$ & 12,091 & $(\$ 156)$ & $\$ 14,026$ & $\$ 13,869$ & $\$ 54,051$ & $26 \%$ \\
\hline
\end{tabular}




\subsection{Cost-Effectiveness Analysis}

The investment or first cost of EEMs is as relevant as energy cost savings. One of the goals that DOE set for this project was that the advanced energy measure package has a payback period of 5 years or less. Based on feedback received from DOE and from users and promoters of previous AEDGs, there is a strong interest in understanding the additional costs necessary to meet recommended energy-performance levels. The cost data provided in this report is intended to represent a reasonable estimate of the incremental costs for an energy-efficient QSR building based on the prototype used in the energy simulations.

The advanced EEMs are estimated to have a national weighted-average payback of 2.1 years. The primary increased costs are the result of the substantially enhanced building envelope, as well as improved kitchen and refrigeration equipment efficiency. Lighting costs are slightly higher for the energy measure packages than for the baseline because of additional controls and more expensive equipment, but these higher costs are offset by the reduced number of fixtures required. The HVAC system cost estimates take into account significantly reduced system capacity resulting from reduced space loads. As discussed in Chapter 5, significant portion of the whole building energy uses for QSRs are attributed to the high energy use of commercial kitchen appliances. They also are the barrier to achieving the 50\% energy saving goal. Unlike many types of building in which energy use is dominated by HVAC and lighting demands, first costs of the EEMs did not appear to be the barrier of the energy saving goal.

Section 6.1 describes the information sources used to develop the incremental costs. Section 6.2 presents the cost effectiveness for the advanced EEM package, and Section 6.3 presents the cost effectiveness of individual EEM packages.

\subsection{Basis for Incremental Energy Efficiency Measure Costs}

Incremental costs for the various EEMs were developed based on the difference between the costs for the baseline measure and the costs for the energy savings measure. The incremental costs may be based on a per unit cost, such as costs per square foot of wall area, or a total cost for an EEM component, such as the cost of a single rooftop air conditioning unit that serves a section of the building. This approach requires that, for each measure, both the baseline cost and the EEM cost must be developed or data must be explicitly available on incremental costs.

This analysis uses incremental costs as the basis of comparison to help offset some of the biases in cost data, when the cost data is deemed to be either routinely high or routinely low. For example, cost data from R.S. Means is generally considered to be slightly high in absolute value by consulting engineers who frequently use data from R.S. Means to develop quick estimates for budgeting purposes. Using differences between the baseline and the advanced energy features costs, whether absolutely high or low, may result in costs that are more representative of the actual incremental cost seen in the industry.

Costs are developed for the baseline and the EEMs used in the building, and then the EEM costs are summed to get the overall cost premium for the advanced building. The advanced costs for lighting and HVAC include added design, calibration, and commissioning costs. Table 6.1 summarizes the basis for estimating both the baseline and EEM costs. 
Table 6.1. Cost Calculation Method Summary

\begin{tabular}{|c|c|c|}
\hline Component & Cost Equation & Source \\
\hline Roof Insulation & $\begin{array}{l}\text { Area of roof times incremental cost/area of } \\
\text { higher insulation value }\end{array}$ & $\begin{array}{l}\text { RS Means Building Construction Cost } \\
\text { Data } 2010\end{array}$ \\
\hline Exterior Wall Insulation & $\begin{array}{l}\text { Area of exterior wall times incremental } \\
\text { cost/area of higher insulation value }\end{array}$ & $\begin{array}{l}\text { RS Means Building Construction Cost } \\
\text { Data } 2010\end{array}$ \\
\hline Slab Insulation & $\begin{array}{l}\text { Area of slab insulation times incremental } \\
\text { cost/area of higher insulation value }\end{array}$ & $\begin{array}{l}\text { RS Means Building Construction Cost } \\
\text { Data } 2010\end{array}$ \\
\hline Cool Roof & $\begin{array}{l}\text { Area of roof area times incremental } \\
\text { cost/area of higher insulation value }\end{array}$ & $\begin{array}{l}\text { Cool Roof data base information from } \\
30 \% \text { TSD for highway lodging }\end{array}$ \\
\hline Windows & $\begin{array}{l}\text { Area of windows times incremental } \\
\text { cost/area of window type based on overall } \\
u \text {-value }\end{array}$ & $\begin{array}{l}\text { ASHRAE SSPC } 90.1 \text { Envelope } \\
\text { Committee supporting fenestration data, } \\
\text { Leisen-Fen }\end{array}$ \\
\hline Interior Lighting & $\begin{array}{l}\text { Incremental cost of lighting, controls and } \\
\text { design }\end{array}$ & Seattle Lighting Lab \\
\hline Exterior Lighting & $\begin{array}{l}\text { Incremental cost of exterior lighting, } \\
\text { controls and design }\end{array}$ & Seattle Lighting Lab \\
\hline $\begin{array}{l}\text { Kitchen Appliances and } \\
\text { Ventilation Systems }\end{array}$ & $\begin{array}{l}\text { Incremental cost of more efficient } \\
\text { equipment and added controls }\end{array}$ & FNI and Halton \\
\hline Air-to-air heat recovery & $\begin{array}{l}\text { Incremental cost of a heat recovery } \\
\text { ventilator. }\end{array}$ & FNI and Halton \\
\hline $\begin{array}{l}\text { Packaged Rooftop } \\
\text { HVAC System }\end{array}$ & $\begin{array}{l}\text { Cost of advanced system minus cost of } \\
\text { baseline system. Costs based on cost per } \\
\text { ton/MBH }\end{array}$ & $\begin{array}{l}\text { RS Means Building Mechanical Cost } \\
\text { Data } 2010\end{array}$ \\
\hline Refrigeration & $\begin{array}{l}\text { Incremental cost of more efficient } \\
\text { equipment and energy conservation } \\
\text { measures. }\end{array}$ & FNI and Halton \\
\hline Service Water Heating & $\begin{array}{l}\text { Incremental cost of more efficient } \\
\text { equipment }\end{array}$ & FNI and Halton \\
\hline
\end{tabular}

\subsection{Cost Analysis - Complete EEM Package}

The advanced EEM package for the QSR building consists of major improvements to the following four categories: the envelope, lighting, commercial kitchen appliances, and mechanical systems. These energy efficiency measures are described in greater detail in Chapter 4.0. In Section 6.3, the cost effectiveness of each EEM package is separately evaluated.

\subsubsection{Incremental Costs}

Incremental costs are calculated using the methodology described in Section 6.1. The incremental cost values are shown in Table 6.2. Values shown in red and enclosed in brackets indicate that the costs for the line item in the advanced case are lower than for the baseline. For HVAC system and control, the incremental costs are negative for many of the climate zones because of a reduction in capacity of the rooftop units in the advanced case compared to baseline case. The reductions in cooling load are the result of greatly reduced lighting and kitchen equipment loads, and outdoor air flow. A location cost 
index (R.S.Means 2010) is applied for different cities that gives a closer estimate of costs in that particular location.

\subsubsection{Unit Costs per Area}

Another measure of cost is cost per unit of area. Armed with this information, designers and owners can quickly evaluate the estimated cost premiums for meeting the recommendations of the TSD. Within the design and construction community, the quick evaluation of cost premiums versus the expected cost per area may serves as a surrogate for cost effectiveness in many cases. Table 6.3 provides the per unit area cost premiums compared to the median baseline construction.

For restaurants, the 2010 version of R.S. Means Construction Cost Data (R.S.Means 2010) indicates that the median unit construction cost is $\$ 170 / \mathrm{ft}^{2}\left(\$ 1827 / \mathrm{m}^{2}\right)$. This value is for a restaurant building with a typical size identified as $4400 \mathrm{ft}^{2}\left(409 \mathrm{~m}^{2}\right)$, which must be adjusted for the size of the modeled prototype QSR building. For this analysis, adjusted median unit construction costs are chosen and are then readjusted for R.S. Means city cost indices. Cost premiums are developed using the incremental costs for the energy savings measures in each climate zone. The national weighted-average cost premium is $\$ 16.46 / \mathrm{ft}^{2}\left(\$ 177.12 / \mathrm{m}^{2}\right)$, or $8.9 \%$.

\subsubsection{Cost-Effectiveness}

Cost effectiveness can also be considered by looking at simple payback period for the EEMs. Table 6.4 shows simple payback values varying from 1.5 to 3.5 years, with a national weighted-average of 2.1 years. The variability in payback results from multiple factors such as differing energy cost savings, reductions in cooling capacity, differences in the R.S. Means cost factor for different locations, and step changes in component performance such as insulation value and cost. The simple payback for each climate zone is calculated by dividing the total incremental cost of the measures by the energy savings in dollars. The energy cost savings calculation is documented in Section 5.3.

Section 6.3 presents the cost effectiveness of individual EEM packages. For the QSR building, the largest energy consumption occurs in the kitchen zone through the kitchen cooking appliances and equipment. It is also where the greatest energy savings were achieved through the implementation of EEMs described in Section 4.3. The incremental cost of implementing the recommended kitchen EEMs is small compared to the energy cost savings that can be achieved (Section 5.4). The energy savings from the envelope, lighting, and mechanical-system EEMs are small compared to those from the kitchen EEMs. As a result, the kitchen EEMs and their associated savings are the driving factors in reducing the overall payback period of the advanced EEM package. 
Table 6.2. Incremental Costs

\begin{tabular}{|c|c|c|c|c|c|c|c|c|c|c|c|c|c|c|c|c|}
\hline & $1 \mathrm{~A}$ & $2 \mathrm{~A}$ & $2 \mathrm{~B}$ & $3 \mathrm{~A}$ & 3B-CA & 3B-other & $3 \mathrm{C}$ & $4 \mathrm{~A}$ & $4 \mathrm{~B}$ & $4 \mathrm{C}$ & $5 \mathrm{~A}$ & $5 \mathrm{~B}$ & $6 \mathrm{~A}$ & $6 \mathrm{~B}$ & 7 & 8 \\
\hline Component & Miami & Houston & Phoenix & Atlanta & $\begin{array}{c}\text { Los } \\
\text { Angeles }\end{array}$ & $\begin{array}{c}\text { Las } \\
\text { Vegas }\end{array}$ & $\begin{array}{c}\text { San } \\
\text { Francisco }\end{array}$ & Baltimore & Albuquerque & Seattle & Chicago & Denver & Minneapolis & Helena & Duluth & Fairbanks \\
\hline Roof Insulation & $\$ 5,165$ & $\$ 5,165$ & $\$ 5,165$ & $\$ 5,165$ & $\$ 5,165$ & $\$ 5,165$ & $\$ 5,165$ & $\$ 5,165$ & $\$ 5,165$ & $\$ 5,165$ & $\$ 8,016$ & $\$ 8,016$ & $\$ 5,938$ & $\$ 5,938$ & $\$ 5,938$ & $\$ 5,938$ \\
\hline $\begin{array}{l}\text { Exterior Wall } \\
\text { Insulation }\end{array}$ & $\$ 0$ & $\$ 2,221$ & $\$ 2,221$ & $\$ 2,221$ & $\$ 2,221$ & $\$ 2,221$ & $\$ 2,221$ & $\$ 3,702$ & $\$ 3,702$ & $\$ 3,702$ & $\$ 3,702$ & $\$ 3,702$ & $\$ 6,196$ & $\$ 6,196$ & $\$ 5,572$ & $\$ 2,494$ \\
\hline Slab Insulation & $\$ 0$ & $\$ 0$ & $\$ 0$ & $\$ 0$ & $\$ 0$ & $\$ 0$ & $\$ 0$ & $\$ 0$ & $\$ 0$ & $\$ 0$ & $\$ 0$ & $\$ 0$ & $\$ 0$ & $\$ 773$ & $\$ 773$ & $\$ 168$ \\
\hline Cool Roof & $\$ 1,789$ & $\$ 1,789$ & $\$ 1,789$ & $\$ 1,789$ & $\$ 1,789$ & $\$ 1,789$ & $\$ 1,789$ & & & & & & & & & \\
\hline Windows & $\$ 3,880$ & $\$ 3,880$ & $\$ 3,880$ & $\$ 596$ & $\$ 596$ & $\$ 596$ & $\$ 4,326$ & $\$ 2,377$ & $\$ 2,377$ & $\$ 2,377$ & $\$ 2,377$ & $\$ 2,377$ & $\$ 3,552$ & $\$ 3,552$ & $\$ 5,852$ & $\$ 5,256$ \\
\hline Interior Lighting & \multicolumn{16}{|c|}{$(\$ 2,119)$} \\
\hline Exterior Lighting & \multicolumn{16}{|c|}{$\$ 600$} \\
\hline Kitchen Equipment & \multicolumn{16}{|c|}{$\$ 13,400$} \\
\hline $\begin{array}{l}\text { Refrigeration } \\
\text { Equipment }\end{array}$ & \multicolumn{16}{|c|}{$\$ 7,700$} \\
\hline $\begin{array}{l}\text { HVAC System \& } \\
\text { Controls }\end{array}$ & $(\$ 2,420)$ & $(\$ 3,577)$ & $(\$ 2,518)$ & $(\$ 2,713)$ & $(\$ 270)$ & $(\$ 9,262)$ & $\$ 5,062$ & $(\$ 2,872)$ & $(\$ 5,330)$ & $\$ 1,661$ & $\$ 14,358$ & $(\$ 3,423)$ & $\$ 14,225$ & $\$ 18,489$ & $\$ 12,555$ & $\$ 19,136$ \\
\hline $\begin{array}{l}\text { Service Water } \\
\text { Heater }\end{array}$ & \multicolumn{16}{|c|}{$\$ 6,500$} \\
\hline Sub-total & $\$ 34,495$ & $\$ 35,558$ & $\$ 36,618$ & $\$ 33,138$ & $\$ 35,582$ & $\$ 26,589$ & $\$ 44,643$ & $\$ 34,452$ & $\$ 31,994$ & $\$ 38,986$ & $\$ 54,533$ & $\$ 36,752$ & $\$ 55,991$ & $\$ 61,029$ & $\$ 56,771$ & $\$ 59,073$ \\
\hline $\begin{array}{l}\text { Location Cost Index } \\
\text { (RS Means 2010) }\end{array}$ & $91 \%$ & $87 \%$ & $89 \%$ & $89 \%$ & $108 \%$ & $107 \%$ & $124 \%$ & $92 \%$ & $89 \%$ & $105 \%$ & $116 \%$ & $94 \%$ & $112 \%$ & $88 \%$ & $106 \%$ & $121 \%$ \\
\hline TOTAL & $\$ 31,356$ & $\$ 30,900$ & $\$ 32,480$ & $\$ 29,427$ & $\$ 38,428$ & $\$ 28,371$ & $\$ 55,268$ & $\$ 31,765$ & $\$ 28,411$ & $\$ 40,779$ & $\$ 63,259$ & $\$ 34,658$ & $\$ 62,430$ & $\$ 53,766$ & $\$ 59,950$ & $\$ 71,183$ \\
\hline
\end{tabular}


Table 6.3. Unit Cost Increase

\begin{tabular}{|c|c|c|c|c|c|c|c|c|c|}
\hline $\begin{array}{l}\text { Climate } \\
\text { Zone }\end{array}$ & City & $\begin{array}{c}\text { Incremental } \\
\text { Cost }\end{array}$ & $\begin{array}{l}\text { Unit Cost } \\
\text { Increase, } \\
\$ / \mathrm{ft}^{2}\end{array}$ & $\$ / m^{2}$ & $\begin{array}{l}\text { Location } \\
\text { Adjusted } \\
\text { Baseline } \\
\text { Median Unit } \\
\text { Cost, } \$ / \mathrm{ft}^{2}\end{array}$ & $\$ / m^{2}$ & $\begin{array}{c}\text { Advanced Unit } \\
\text { Construction } \\
\text { Cost } \\
\$ / \mathrm{ft}^{2}\end{array}$ & $\$ / m^{2}$ & $\begin{array}{l}\text { Percentage of } \\
\text { Unit Cost } \\
\text { Increase Over } \\
\text { Unit Median } \\
\text { Baseline }\end{array}$ \\
\hline $1 \mathrm{~A}$ & Miami & $\$ 31,356$ & $\$ 12.80$ & $\$ 137.76$ & $\$ 167$ & $\$ 1,796$ & $\$ 180$ & $\$ 1,934$ & $7.7 \%$ \\
\hline $2 \mathrm{~A}$ & Houston & $\$ 30,900$ & $\$ 12.61$ & $\$ 135.76$ & $\$ 160$ & $\$ 1,717$ & $\$ 172$ & $\$ 1,853$ & $7.9 \%$ \\
\hline $2 \mathrm{~B}$ & Phoenix & $\$ 32,480$ & $\$ 13.26$ & $\$ 142.70$ & $\$ 163$ & $\$ 1,753$ & $\$ 176$ & $\$ 1,896$ & $8.1 \%$ \\
\hline $3 \mathrm{~A}$ & Atlanta & $\$ 29,427$ & $\$ 12.01$ & $\$ 129.28$ & $\$ 163$ & $\$ 1,755$ & $\$ 175$ & $\$ 1,884$ & $7.4 \%$ \\
\hline $3 \mathrm{~B}$ & Los Angeles & $\$ 38,428$ & $\$ 15.68$ & $\$ 168.83$ & $\$ 198$ & $\$ 2,134$ & $\$ 214$ & $\$ 2,303$ & $7.9 \%$ \\
\hline $3 B$ & Las Vegas & $\$ 28,371$ & $\$ 11.58$ & $\$ 124.65$ & $\$ 196$ & $\$ 2,109$ & $\$ 207$ & $\$ 2,233$ & $5.9 \%$ \\
\hline $3 \mathrm{C}$ & San Fran. & $\$ 55,268$ & $\$ 22.56$ & $\$ 242.82$ & $\$ 227$ & $\$ 2,447$ & $\$ 250$ & $\$ 2,689$ & $9.9 \%$ \\
\hline $4 \mathrm{~A}$ & Baltimore & $\$ 31,765$ & $\$ 12.97$ & $\$ 139.56$ & $\$ 169$ & $\$ 1,822$ & $\$ 182$ & $\$ 1,962$ & $7.7 \%$ \\
\hline $4 \mathrm{~B}$ & Albuquerque & $\$ 28,411$ & $\$ 11.60$ & $\$ 124.82$ & $\$ 163$ & $\$ 1,755$ & $\$ 175$ & $\$ 1,880$ & $7.1 \%$ \\
\hline $4 \mathrm{C}$ & Seattle & $\$ 40,779$ & $\$ 16.64$ & $\$ 179.16$ & $\$ 192$ & $\$ 2,067$ & $\$ 209$ & $\$ 2,246$ & $8.7 \%$ \\
\hline $5 \mathrm{~A}$ & Chicago & $\$ 63,259$ & $\$ 25.82$ & $\$ 277.92$ & $\$ 213$ & $\$ 2,292$ & $\$ 239$ & $\$ 2,570$ & $12.1 \%$ \\
\hline $5 B$ & Denver & $\$ 34,658$ & $\$ 14.15$ & $\$ 152.27$ & $\$ 173$ & $\$ 1,864$ & $\$ 187$ & $\$ 2,016$ & $8.2 \%$ \\
\hline $6 \mathrm{~A}$ & Minneapolis & $\$ 62,430$ & $\$ 25.48$ & $\$ 274.28$ & $\$ 205$ & $\$ 2,204$ & $\$ 230$ & $\$ 2,478$ & $12.4 \%$ \\
\hline $6 \mathrm{~B}$ & Helena & $\$ 53,766$ & $\$ 21.95$ & $\$ 236.22$ & $\$ 162$ & $\$ 1,741$ & $\$ 184$ & $\$ 1,977$ & $13.6 \%$ \\
\hline 7 & Duluth & $\$ 59,950$ & $\$ 24.47$ & $\$ 263.39$ & $\$ 194$ & $\$ 2,087$ & $\$ 218$ & $\$ 2,350$ & $12.6 \%$ \\
\hline 8 & Fairbanks & $\$ 71,183$ & $\$ 29.05$ & $\$ 312.74$ & $\$ 221$ & $\$ 2,381$ & $\$ 250$ & $\$ 2,694$ & $13.1 \%$ \\
\hline
\end{tabular}


Table 6.4. Simple Payback Period

\begin{tabular}{|c|c|c|c|c|c|c|}
\hline \multirow{2}{*}{$\begin{array}{c}\text { Climate } \\
\text { Zone }\end{array}$} & \multirow[b]{2}{*}{ City } & \multirow{2}{*}{$\begin{array}{c}\text { Incremental } \\
\text { Cost }\end{array}$} & \multicolumn{3}{|c|}{ Energy Cost Savings } & \multirow{2}{*}{$\begin{array}{l}\text { Simple } \\
\text { Payback } \\
\text { (years) }\end{array}$} \\
\hline & & & Electricity & Natural Gas & Total & \\
\hline $1 \mathrm{~A}$ & Miami & $\$ 31,356$ & $\$ 14,574$ & $\$ 5,943$ & $\$ 20,517$ & 1.5 \\
\hline $2 \mathrm{~A}$ & Houston & $\$ 30,900$ & $\$ 13,248$ & $\$ 6,817$ & $\$ 20,065$ & 1.5 \\
\hline $2 \mathrm{~B}$ & Phoenix & $\$ 32,480$ & $\$ 12,178$ & $\$ 6,480$ & $\$ 18,658$ & 1.7 \\
\hline $3 \mathrm{~A}$ & Atlanta & $\$ 29,427$ & $\$ 11,688$ & $\$ 7,531$ & $\$ 19,219$ & 1.5 \\
\hline 3B & Los Angeles & $\$ 38,428$ & $\$ 9,060$ & $\$ 6,489$ & $\$ 15,549$ & 2.5 \\
\hline $3 \mathrm{~B}$ & Las Vegas & $\$ 28,371$ & $\$ 11,100$ & $\$ 6,833$ & $\$ 17,934$ & 1.6 \\
\hline $3 \mathrm{C}$ & San Fran. & $\$ 55,268$ & $\$ 8,323$ & $\$ 7,457$ & $\$ 15,780$ & 3.5 \\
\hline $4 \mathrm{~A}$ & Baltimore & $\$ 31,765$ & $\$ 10,824$ & $\$ 8,895$ & $\$ 19,719$ & 1.6 \\
\hline 4B & Albuquerque & $\$ 28,411$ & $\$ 9,720$ & $\$ 7,679$ & $\$ 17,399$ & 1.6 \\
\hline $4 \mathrm{C}$ & Seattle & $\$ 40,779$ & $\$ 8,332$ & $\$ 8,377$ & $\$ 16,709$ & 2.4 \\
\hline $5 \mathrm{~A}$ & Chicago & $\$ 63,259$ & $\$ 8,690$ & $\$ 10,747$ & $\$ 19,436$ & 3.3 \\
\hline $5 \mathrm{~B}$ & Denver & $\$ 34,658$ & $\$ 9,275$ & $\$ 8,682$ & $\$ 17,957$ & 1.9 \\
\hline $6 \mathrm{~A}$ & Minneapolis & $\$ 62,430$ & $\$ 8,453$ & $\$ 12,579$ & $\$ 21,031$ & 3.0 \\
\hline $6 \mathrm{~B}$ & Helena & $\$ 53,766$ & $\$ 7,760$ & $\$ 10,878$ & $\$ 18,639$ & 2.9 \\
\hline 7 & Duluth & $\$ 59,950$ & $\$ 7,618$ & $\$ 14,183$ & $\$ 21,801$ & 2.7 \\
\hline 8 & Fairbanks & $\$ 71,183$ & $\$ 7,281$ & $\$ 18,454$ & $\$ 25,734$ & 2.8 \\
\hline
\end{tabular}

\subsection{Cost Analysis - Individual EEM Packages}

Owners of quick-service restaurants may choose to implement a subset of the energy efficiency measures presented in Chapter 4.0. It is valuable to understand the impact of each of these individual EEMs on the energy usage as well as the associated costs and payback. The building envelope, lighting, kitchen appliances, and mechanical systems are the four EEM packages for which separate cost effectiveness analysis is presented in the following sections.

Each EEM package impacts the size of the HVAC system that is calculated dynamically for each climate zone by EnergyPlus. A smaller HVAC system means lower capital outlay compared to the baseline, and this must be accounted for when evaluating the cost effectiveness of a particular EEM. Therefore, HVAC costs for each EEM package are included in the calculation of total incremental costs.

\subsubsection{Envelope EEM Package}

The envelope EEM package includes improved insulation levels for the exterior walls, roof and slab; efficient windows; and a cool roof. Section 4.1 describes these recommended envelope EEMs in greater detail. Table 6.5 shows the incremental cost of implementing this EEM package. The incremental costs also include the HVAC cost savings associated with a reduction in size of the equipment. Table 6.6 shows the energy cost savings and the simple payback resulting from the addition of the EEM package to the baseline building. The national weighted unit cost increase for this EEM package is $\$ 4.85 / \mathrm{ft}^{2}$ $\left(\$ 52.21 / \mathrm{m}^{2}\right)$, or $2.7 \%$. 
Table 6.5. Incremental Costs for the Envelope EEM Package

\begin{tabular}{|c|c|c|c|c|c|c|c|c|c|c|c|c|c|c|c|c|}
\hline & $1 \mathrm{~A}$ & $2 \mathrm{~A}$ & $2 \mathrm{~B}$ & $3 \mathrm{~A}$ & 3B-CA & 3B-other & $3 \mathrm{C}$ & $4 \mathrm{~A}$ & 4B & $4 \mathrm{C}$ & $5 \mathrm{~A}$ & $5 \mathrm{~B}$ & $6 \mathrm{~A}$ & $6 \mathrm{~B}$ & 7 & 8 \\
\hline Component & Miami & Houston & Phoenix & Atlanta & $\begin{array}{c}\text { Los } \\
\text { Angeles }\end{array}$ & $\begin{array}{l}\text { Las } \\
\text { Vegas }\end{array}$ & $\begin{array}{c}\text { San } \\
\text { Francisco }\end{array}$ & Baltimore & Albuquerque & Seattle & Chicago & Denver & Minneapolis & Helena & Duluth & Fairbanks \\
\hline Roof Insulation & $\$ 5,165$ & $\$ 5,165$ & $\$ 5,165$ & $\$ 5,165$ & $\$ 5,165$ & $\$ 5,165$ & $\$ 5,165$ & $\$ 5,165$ & $\$ 5,165$ & $\$ 5,165$ & $\$ 8,016$ & $\$ 8,016$ & $\$ 5,938$ & $\$ 5,938$ & $\$ 5,938$ & $\$ 5,938$ \\
\hline $\begin{array}{l}\text { Exterior Wall } \\
\text { Insulation }\end{array}$ & $\$ 0$ & $\$ 2,221$ & $\$ 2,221$ & $\$ 2,221$ & $\$ 2,221$ & $\$ 2,221$ & $\$ 2,221$ & $\$ 3,702$ & $\$ 3,702$ & $\$ 3,702$ & $\$ 3,702$ & $\$ 3,702$ & $\$ 6,196$ & $\$ 6,196$ & $\$ 5,572$ & $\$ 2,494$ \\
\hline Slab Insulation & $\$ 0$ & $\$ 0$ & $\$ 0$ & $\$ 0$ & $\$ 0$ & $\$ 0$ & $\$ 0$ & $\$ 0$ & $\$ 0$ & $\$ 0$ & $\$ 0$ & $\$ 0$ & $\$ 0$ & $\$ 773$ & $\$ 773$ & $\$ 168$ \\
\hline Cool Roof & $\$ 1,789$ & $\$ 1,789$ & $\$ 1,789$ & $\$ 1,789$ & $\$ 1,789$ & $\$ 1,789$ & $\$ 1,789$ & & & & & & & & & \\
\hline Windows & $\$ 3,880$ & $\$ 3,880$ & $\$ 3,880$ & $\$ 596$ & $\$ 596$ & $\$ 596$ & $\$ 4,326$ & $\$ 2,377$ & $\$ 2,377$ & $\$ 2,377$ & $\$ 2,377$ & $\$ 2,377$ & $\$ 3,552$ & $\$ 3,552$ & $\$ 5,852$ & $\$ 5,256$ \\
\hline $\begin{array}{l}\text { HVAC System \& } \\
\text { Controls }\end{array}$ & $(\$ 12)$ & $(\$ 32)$ & $(\$ 40)$ & $(\$ 29)$ & $(\$ 24)$ & $(\$ 3,636)$ & $(\$ 25)$ & $(\$ 46)$ & $(\$ 2,194)$ & $(\$ 34)$ & $(\$ 47)$ & $(\$ 72)$ & $(\$ 33)$ & $(\$ 43)$ & $(\$ 50)$ & $(\$ 3,158)$ \\
\hline Sub-total & $\$ 10,822$ & $\$ 13,023$ & $\$ 13,015$ & $\$ 9,741$ & $\$ 9,746$ & $\$ 6,134$ & $\$ 13,475$ & $\$ 11,198$ & $\$ 9,050$ & $\$ 11,210$ & $\$ 14,047$ & $\$ 14,023$ & $\$ 15,653$ & $\$ 16,416$ & $\$ 18,086$ & $\$ 10,698$ \\
\hline $\begin{array}{l}\text { Location Cost Index } \\
\text { (RS Means 2010) } \\
\end{array}$ & $91 \%$ & $87 \%$ & $89 \%$ & $89 \%$ & $108 \%$ & $107 \%$ & $124 \%$ & $92 \%$ & $89 \%$ & $105 \%$ & $116 \%$ & $94 \%$ & $112 \%$ & $88 \%$ & $106 \%$ & $121 \%$ \\
\hline TOTAL & $\$ 9,837$ & $\$ 11,317$ & $\$ 11,544$ & $\$ 8,650$ & $\$ 10,526$ & $\$ 6,545$ & $\$ 16,683$ & $\$ 10,325$ & $\$ 8,036$ & $\$ 11,726$ & $\$ 16,295$ & $\$ 13,223$ & $\$ 17,453$ & $\$ 14,462$ & $\$ 19,098$ & $\$ 12,892$ \\
\hline
\end{tabular}


Table 6.6. Simple Payback Period for the Envelope EEM Package

\begin{tabular}{|c|c|c|c|c|c|c|}
\hline \multirow{2}{*}{$\begin{array}{c}\text { Climate } \\
\text { Zone }\end{array}$} & \multirow[b]{2}{*}{ City } & \multirow{2}{*}{$\begin{array}{c}\text { Incremental } \\
\text { Cost }\end{array}$} & \multicolumn{3}{|c|}{ Energy Cost Savings } & \multirow{2}{*}{$\begin{array}{c}\text { Simple } \\
\text { Payback } \\
\text { (Years) }\end{array}$} \\
\hline & & & Electricity & Natural Gas & Total & \\
\hline $1 \mathrm{~A}$ & Miami & $\$ 9,837$ & $\$ 11$ & $\$ 7$ & $\$ 19$ & 525.1 \\
\hline $2 \mathrm{~A}$ & Houston & $\$ 11,317$ & $\$ 9$ & $\$ 105$ & $\$ 114$ & 99.4 \\
\hline $2 \mathrm{~B}$ & Phoenix & $\$ 11,544$ & $\$ 124$ & $\$ 80$ & $\$ 204$ & 56.7 \\
\hline $3 \mathrm{~A}$ & Atlanta & $\$ 8,650$ & $\$ 6$ & $\$ 65$ & $\$ 71$ & 121.1 \\
\hline $3 \mathrm{~B}$ & Los Angeles & $\$ 10,526$ & $\$ 5$ & $\$ 28$ & $\$ 33$ & 315.5 \\
\hline $3 \mathrm{~B}$ & Las Vegas & $\$ 6,545$ & $\$ 101$ & $\$ 30$ & $\$ 131$ & 49.9 \\
\hline $3 \mathrm{C}$ & San Fran. & $\$ 16,683$ & $(\$ 22)$ & $\$ 158$ & $\$ 136$ & 122.8 \\
\hline $4 \mathrm{~A}$ & Baltimore & $\$ 10,325$ & $\$ 38$ & $\$ 172$ & $\$ 210$ & 49.1 \\
\hline $4 \mathrm{~B}$ & Albuquerque & $\$ 8,036$ & $\$ 147$ & $\$ 89$ & $\$ 235$ & 34.1 \\
\hline $4 \mathrm{C}$ & Seattle & $\$ 11,726$ & $(\$ 8)$ & $\$ 163$ & $\$ 156$ & 75.2 \\
\hline $5 \mathrm{~A}$ & Chicago & $\$ 16,295$ & $\$ 54$ & $\$ 257$ & $\$ 311$ & 52.4 \\
\hline $5 B$ & Denver & $\$ 13,223$ & $\$ 132$ & $\$ 163$ & $\$ 295$ & 44.8 \\
\hline $6 \mathrm{~A}$ & Minneapolis & $\$ 17,453$ & $(\$ 20)$ & $\$ 425$ & $\$ 406$ & 43.0 \\
\hline $6 \mathrm{~B}$ & Helena & $\$ 14,462$ & $\$ 22$ & $\$ 369$ & $\$ 391$ & 37.0 \\
\hline 7 & Duluth & $\$ 19,098$ & $\$ 39$ & $\$ 564$ & $\$ 603$ & 31.7 \\
\hline 8 & Fairbanks & $\$ 12,892$ & $\$ 8$ & $\$ 315$ & $\$ 323$ & 39.9 \\
\hline
\end{tabular}

The national weighted average payback period for the envelope EEM package is 91.5 years. From Table 6.6, it can be seen that the simple payback period is very high for the envelope EEM package across all locations, especially in the warm climates. The energy consumption of a QSR is mainly driven by the energy use of its food preparation equipment and the substantial heat gain released by the kitchen appliances. The basis of the envelope EEMs is Addendum bb to Standard 90.1-2007, which was proposed as an EEM for general buildings to reduce the building thermal load through its enclosure. Based on the high payback period among the four EEM categories, the building envelope EEM package may be given a lower priority by QSR design teams when investment decisions are to be made. The authors believe that once the efficiency of cooking appliances is significantly improved in the future, the envelope EEM package would become more economically attractive.

\subsubsection{Lighting EEM Package}

The lighting EEM package includes reduced LPD, occupancy controls, improved interior lighting power management, and daylight harvesting. Section 4.2 describes these recommended energy efficiency measures in greater detail.

The energy saving and energy cost saving results of the package were presented previously in Table 5.8 and Table 5.9. From Table 6.2, it can be seen that the total incremental cost for the interior and exterior lighting EEM is negative. This is because even though controls and higher efficiency lamps are more expensive, the added cost is offset by the reduced number of fixtures. The negative incremental cost indicates that payback is immediate for implementing the recommended lighting energy efficiency measures into the design of QSRs. 


\subsubsection{Commercial Kitchen Appliance EEM Package}

The kitchen appliance EEM package includes energy-efficient hooded and unhooded cooking appliances and energy-efficient refrigeration equipment. Section 4.3 describes these recommended EEMs in greater detail. Cost data for each kitchen appliance EEM were available as a range. Therefore, the cost effectiveness analysis presented below is broken down into minimum and maximum incremental costs and their related impacts on the simple payback period. Table 6.7 and Table 6.8 show the minimum and maximum incremental costs, while Table 6.9 and Table 6.10 show the associated simple payback period for minimum and maximum incremental costs for the kitchen appliance EEM package.

The incremental costs also include the HVAC cost savings associated with a reduction in size of the equipment. Table 6.7 shows a negative incremental cost for Albuquerque, New Mexico. This negative incremental cost is because of the combined effect of a large reduction in size of the DX cooling coils and gas furnace, and the minimum range incremental cost for kitchen appliance EEMs.

An average of the minimum and maximum incremental costs for this EEM package yields a national weighted unit cost increase of $\$ 3.83 / \mathrm{ft}^{2}\left(\$ 41.26 / \mathrm{m}^{2}\right)$, or $2.1 \%$.

The national weighted average payback period is 0.9 year. The kitchen equipment is the major energy consumer for a QSR building so the kitchen equipment EEM package is highly recommended as it is likely to produce the most energy and cost savings.

\subsubsection{Mechanical Systems EEM Package}

The mechanical systems EEM package includes improved DOAS, higher efficiency HVAC equipment, reduced exhaust flow using proximity type of hoods, demand-control ventilation for the exhaust hoods, extended use of an economizer, air-to-air heat recovery, higher efficiency water heater, and heat recovery from the refrigerant to the service hot water. Sections 4.4 and 4.5 describe these recommended energy efficiency measures in greater detail.

The cost of the rooftop units, which depends on the size of the cooling and heating equipment, is derived from the R.S. Means database. The cost data for the remaining EEMs was available as a range, similar to the kitchen ventilation equipment cost data. The cost effectiveness analysis presented below is broken down into minimum and maximum incremental costs associated with the EEMs and their related impacts on the simple payback period. The incremental cost related to the size of the HVAC equipment is the same for both the minimum and maximum incremental costs. Table 6.11 and Table 6.12 show the minimum and maximum incremental costs, while Table 6.13 and Table 6.14 show the associated simple payback period for minimum and maximum incremental costs for the mechanical systems EEM package.

An average of the minimum and maximum incremental costs for the mechanical systems EEM package yields a national weighted unit cost increase of $\$ 8.18 / \mathrm{ft}^{2}\left(\$ 88.00 / \mathrm{m}^{2}\right)$, or $4.3 \%$. 
Table 6.7. Incremental Costs for the Kitchen Appliance EEM Package - Minimum Incremental Cost

\begin{tabular}{|c|c|c|c|c|c|c|c|c|c|c|c|c|c|c|c|c|}
\hline & $1 \mathrm{~A}$ & $2 \mathrm{~A}$ & $2 \mathrm{~B}$ & $3 \mathrm{~A}$ & 3B-CA & 3B-other & $3 \mathrm{C}$ & $4 \mathrm{~A}$ & $4 \mathrm{~B}$ & $4 \mathrm{C}$ & $5 \mathrm{~A}$ & $5 \mathrm{~B}$ & $6 \mathrm{~A}$ & $6 \mathrm{~B}$ & 7 & 8 \\
\hline Component & Miami & Houston & Phoenix & Atlanta & $\begin{array}{c}\text { Los } \\
\text { Angeles }\end{array}$ & Las Vegas & $\begin{array}{c}\text { San } \\
\text { Francisco }\end{array}$ & Baltimore & Albuquerque & Seattle & Chicago & Denver & Minneapolis & Helena & Duluth & Fairbanks \\
\hline Kitchen Equipment & \multicolumn{16}{|c|}{$\$ 9,100$} \\
\hline $\begin{array}{l}\text { Refrigeration } \\
\text { Equipment }\end{array}$ & \multicolumn{16}{|c|}{$\$ 5,900$} \\
\hline $\begin{array}{l}\text { HVAC System \& } \\
\text { Controls }\end{array}$ & $(\$ 12,248)$ & $(\$ 12,241)$ & $(\$ 12,244)$ & $(\$ 9,105)$ & $(\$ 9,292)$ & $(\$ 12,708)$ & $(\$ 5,918)$ & $(\$ 12,250)$ & $(\$ 16,006)$ & $(\$ 9,289)$ & $(\$ 12,251)$ & $(\$ 13,884)$ & $(\$ 12,249)$ & $(\$ 9,311)$ & $(\$ 8,783)$ & $(\$ 9,067)$ \\
\hline Sub-total & $\$ 2,752$ & $\$ 2,759$ & $\$ 2,756$ & $\$ 5,895$ & $\$ 5,708$ & $\$ 2,292$ & $\$ 9,082$ & $\$ 2,750$ & $(\$ 1,006)$ & $\$ 5,711$ & $\$ 2,749$ & $\$ 1,116$ & $\$ 2,751$ & $\$ 5,689$ & $\$ 6,217$ & $\$ 5,933$ \\
\hline $\begin{array}{l}\text { Location Cost Index } \\
\text { (RS Means 2010) }\end{array}$ & $91 \%$ & $87 \%$ & $89 \%$ & $89 \%$ & $108 \%$ & $107 \%$ & $124 \%$ & $92 \%$ & $89 \%$ & $105 \%$ & $116 \%$ & $94 \%$ & $112 \%$ & $88 \%$ & $106 \%$ & $121 \%$ \\
\hline TOTAL & $\$ 2,502$ & $\$ 2,398$ & $\$ 2,445$ & $\$ 5,235$ & $\$ 6,165$ & $\$ 2,446$ & $\$ 11,244$ & $\$ 2,535$ & $(\$ 894)$ & $\$ 5,973$ & $\$ 3,189$ & $\$ 1,052$ & $\$ 3,068$ & $\$ 5,012$ & $\$ 6,565$ & $\$ 7,149$ \\
\hline
\end{tabular}

Table 6.8. Incremental Costs for the Kitchen Appliance EEM Package - Maximum Incremental Cost

\begin{tabular}{|c|c|c|c|c|c|c|c|c|c|c|c|c|c|c|c|c|}
\hline & $1 \mathrm{~A}$ & $2 \mathrm{~A}$ & $2 \mathrm{~B}$ & $3 \mathrm{~A}$ & 3B-CA & 3B-other & $3 \mathrm{C}$ & $4 \mathrm{~A}$ & $4 \mathrm{~B}$ & $4 \mathrm{C}$ & $5 \mathrm{~A}$ & $5 \mathrm{~B}$ & $6 \mathrm{~A}$ & $6 \mathrm{~B}$ & 7 & 8 \\
\hline Component & Miami & Houston & Phoenix & Atlanta & $\begin{array}{l}\text { Los } \\
\text { Angeles }\end{array}$ & Las Vegas & $\begin{array}{c}\text { San } \\
\text { Francisco }\end{array}$ & \multicolumn{2}{|c|}{ Baltimore Albuquerque } & Seattle & Chicago & Denver & Minneapolis & Helena & Duluth & Fairbanks \\
\hline Kitchen Equipment & \multicolumn{16}{|c|}{$\$ 17,700$} \\
\hline $\begin{array}{l}\text { Refrigeration } \\
\text { Equipment }\end{array}$ & \multicolumn{16}{|c|}{$\$ 9,500$} \\
\hline $\begin{array}{l}\text { HVAC System \& } \\
\text { Controls }\end{array}$ & $(\$ 12,248)$ & $(\$ 12,241)$ & $(\$ 12,244)$ & $(\$ 9,105)$ & $(\$ 9,292)$ & $(\$ 12,708)$ & $(\$ 5,918)$ & $(\$ 12,250)$ & $(\$ 16,006)$ & $(\$ 9,289)$ & $(\$ 12,251)$ & $(\$ 13,884)$ & $(\$ 12,249)$ & $(\$ 9,311)$ & $(\$ 8,783)$ & $(\$ 9,067)$ \\
\hline Sub-total & $\$ 14,952$ & $\$ 14,959$ & $\$ 14,956$ & $\$ 18,095$ & $\$ 17,908$ & $\$ 14,492$ & $\$ 21,282$ & $\$ 14,950$ & $\$ 11,194$ & $\$ 17,911$ & $\$ 14,949$ & $\$ 13,316$ & $\$ 14,951$ & $\$ 17,889$ & $\$ 18,417$ & $\$ 18,133$ \\
\hline $\begin{array}{l}\text { Location Cost Index } \\
\text { (RS Means 2010) }\end{array}$ & $91 \%$ & $87 \%$ & $89 \%$ & $89 \%$ & $108 \%$ & $107 \%$ & $124 \%$ & $92 \%$ & $89 \%$ & $105 \%$ & $116 \%$ & $94 \%$ & $112 \%$ & $88 \%$ & $106 \%$ & $121 \%$ \\
\hline TOTAL & $\$ 13,591$ & $\$ 13,000$ & $\$ 13,266$ & $\$ 16,069$ & $\$ 19,341$ & $\$ 15,463$ & $\$ 26,347$ & $\$ 13,784$ & $\$ 9,940$ & $\$ 18,734$ & $\$ 17,341$ & $\$ 12,557$ & $\$ 16,671$ & $\$ 15,760$ & $\$ 19,449$ & $\$ 21,850$ \\
\hline
\end{tabular}


Table 6.9. Simple Payback Period for Kitchen Appliance EEM Package - Minimum Incremental Cost

\begin{tabular}{|c|c|c|c|c|c|c|}
\hline \multirow{2}{*}{$\begin{array}{l}\text { Climate } \\
\text { Zone }\end{array}$} & \multirow[b]{2}{*}{ City } & \multirow{2}{*}{$\begin{array}{c}\text { Incremental } \\
\text { Cost }\end{array}$} & \multicolumn{3}{|c|}{ Energy Cost Savings } & \multirow{2}{*}{$\begin{array}{c}\text { Simple Payback } \\
\text { (Years) }\end{array}$} \\
\hline & & & Electricity & Natural Gas & Total & \\
\hline $1 \mathrm{~A}$ & Miami & $\$ 2,502$ & $\$ 8,730$ & $\$ 5,103$ & $\$ 13,833$ & 0.2 \\
\hline $2 \mathrm{~A}$ & Houston & $\$ 2,398$ & $\$ 7,866$ & $\$ 4,635$ & $\$ 12,500$ & 0.2 \\
\hline $2 \mathrm{~B}$ & Phoenix & $\$ 2,445$ & $\$ 6,803$ & $\$ 4,820$ & $\$ 11,623$ & 0.2 \\
\hline $3 \mathrm{~A}$ & Atlanta & $\$ 5,235$ & $\$ 7,031$ & $\$ 4,226$ & $\$ 11,257$ & 0.5 \\
\hline 3B & Los Angeles & $\$ 6,165$ & $\$ 5,070$ & $\$ 4,900$ & $\$ 9,969$ & 0.6 \\
\hline $3 \mathrm{~B}$ & Las Vegas & $\$ 2,446$ & $\$ 6,029$ & $\$ 4,590$ & $\$ 10,619$ & 0.2 \\
\hline $3 \mathrm{C}$ & San Fran. & $\$ 11,244$ & $\$ 4,474$ & $\$ 4,434$ & $\$ 8,907$ & 1.3 \\
\hline $4 \mathrm{~A}$ & Baltimore & $\$ 2,535$ & $\$ 6,322$ & $\$ 3,590$ & $\$ 9,913$ & 0.3 \\
\hline 4B & Albuquerque & $(\$ 894)$ & $\$ 5,323$ & $\$ 4,044$ & $\$ 9,367$ & N/A \\
\hline $4 \mathrm{C}$ & Seattle & $\$ 5,973$ & $\$ 4,494$ & $\$ 3,529$ & $\$ 8,023$ & 0.7 \\
\hline $5 \mathrm{~A}$ & Chicago & $\$ 3,189$ & $\$ 5,306$ & $\$ 3,231$ & $\$ 8,537$ & 0.4 \\
\hline $5 \mathrm{~B}$ & Denver & $\$ 1,052$ & $\$ 5,056$ & $\$ 3,647$ & $\$ 8,704$ & 0.1 \\
\hline $6 \mathrm{~A}$ & Minneapolis & $\$ 3,068$ & $\$ 5,173$ & $\$ 3,090$ & $\$ 8,263$ & 0.4 \\
\hline $6 \mathrm{~B}$ & Helena & $\$ 5,012$ & $\$ 4,735$ & $\$ 3,134$ & $\$ 7,870$ & 0.6 \\
\hline 7 & Duluth & $\$ 6,565$ & $\$ 4,487$ & $\$ 2,671$ & $\$ 7,158$ & 0.9 \\
\hline 8 & Fairbanks & $\$ 7,149$ & $\$ 4,302$ & $\$ 2,371$ & $\$ 6,673$ & 1.1 \\
\hline
\end{tabular}

Table 6.10. Simple Payback Period for Kitchen Appliance EEM Package - Maximum Incremental Cost

\begin{tabular}{clccccc}
\hline \multirow{2}{*}{$\begin{array}{c}\text { Climate } \\
\text { Zone }\end{array}$} & \multicolumn{1}{c}{ City } & Incremental & \multicolumn{3}{c}{ Energy Cost Savings } & \multicolumn{2}{c}{$\begin{array}{c}\text { Simple } \\
\text { Payback } \\
\text { (Years) }\end{array}$} \\
\cline { 4 - 6 } 1A & Miami & $\$ 13,591$ & $\$ 8,730$ & $\$ 5,103$ & $\$ 13,833$ & 1.0 \\
2A & Houston & $\$ 13,000$ & $\$ 7,866$ & $\$ 4,635$ & $\$ 12,500$ & 1.0 \\
2B & Phoenix & $\$ 13,266$ & $\$ 6,803$ & $\$ 4,820$ & $\$ 11,623$ & 1.1 \\
3A & Atlanta & $\$ 16,069$ & $\$ 7,031$ & $\$ 4,226$ & $\$ 11,257$ & 1.4 \\
3B & Los Angeles & $\$ 19,341$ & $\$ 5,070$ & $\$ 4,900$ & $\$ 9,969$ & 1.9 \\
3B & Las Vegas & $\$ 15,463$ & $\$ 6,029$ & $\$ 4,590$ & $\$ 10,619$ & 1.5 \\
3C & San Fran. & $\$ 26,347$ & $\$ 4,474$ & $\$ 4,434$ & $\$ 8,907$ & 3.0 \\
4A & Baltimore & $\$ 13,784$ & $\$ 6,322$ & $\$ 3,590$ & $\$ 9,913$ & 1.4 \\
4B & Albuquerque & $\$ 9,940$ & $\$ 5,323$ & $\$ 4,044$ & $\$ 9,367$ & 1.1 \\
4C & Seattle & $\$ 18,734$ & $\$ 4,494$ & $\$ 3,529$ & $\$ 8,023$ & 2.3 \\
5A & Chicago & $\$ 17,341$ & $\$ 5,306$ & $\$ 3,231$ & $\$ 8,537$ & 2.0 \\
5B & Denver & $\$ 12,557$ & $\$ 5,056$ & $\$ 3,647$ & $\$ 8,704$ & 1.4 \\
6A & Minneapolis & $\$ 16,671$ & $\$ 5,173$ & $\$ 3,090$ & $\$ 8,263$ & 2.0 \\
6B & Helena & $\$ 15,760$ & $\$ 4,735$ & $\$ 3,134$ & $\$ 7,870$ & 2.0 \\
7 & Duluth & $\$ 19,449$ & $\$ 4,487$ & $\$ 2,671$ & $\$ 7,158$ & 2.7 \\
8 & Fairbanks & $\$ 21,850$ & $\$ 4,302$ & $\$ 2,371$ & $\$ 6,673$ & 3.3 \\
\hline
\end{tabular}


Table 6.11. Incremental Costs for the HVAC EEM Package - Minimum Incremental Cost

\begin{tabular}{|c|c|c|c|c|c|c|c|c|c|c|c|c|c|c|c|c|}
\hline & $1 \mathrm{~A}$ & $2 \mathrm{~A}$ & $2 \mathrm{~B}$ & $3 \mathrm{~A}$ & 3B-CA & 3B-other & $3 \mathrm{C}$ & $4 \mathrm{~A}$ & $4 \mathrm{~B}$ & $4 \mathrm{C}$ & $5 \mathrm{~A}$ & $5 \mathrm{~B}$ & $6 \mathrm{~A}$ & $6 \mathrm{~B}$ & 7 & 8 \\
\hline Component & Miami & Houston & Phoenix & Atlanta & $\begin{array}{c}\text { Los } \\
\text { Angeles }\end{array}$ & $\begin{array}{l}\text { Las } \\
\text { Vegas }\end{array}$ & $\begin{array}{c}\text { San } \\
\text { Francisco }\end{array}$ & Baltimore & Albuquerque & Seattle & Chicago & Denver & Minneapolis & Helena & Duluth & Fairbanks \\
\hline $\begin{array}{l}\text { HVAC System \& } \\
\text { Controls }\end{array}$ & $\$ 10,390$ & $\$ 6,533$ & $\$ 6,605$ & $\$ 6,403$ & $\$ 8,121$ & $\$ 2,943$ & $\$ 10,158$ & $\$ 6,259$ & $\$ 7,883$ & $\$ 10,061$ & $\$ 20,989$ & $\$ 9,774$ & $\$ 20,844$ & $\$ 24,557$ & $\$ 19,925$ & $\$ 24,081$ \\
\hline Service Water Heater & \multicolumn{16}{|c|}{$\$ 4,500$} \\
\hline Sub-total & $\$ 14,890$ & $\$ 11,033$ & $\$ 11,105$ & $\$ 10,903$ & $\$ 12,621$ & $\$ 7,443$ & $\$ 14,658$ & $\$ 10,759$ & $\$ 12,383$ & $\$ 14,561$ & $\$ 25,489$ & $\$ 14,274$ & $\$ 25,344$ & $\$ 29,057$ & $\$ 24,425$ & $\$ 28,581$ \\
\hline $\begin{array}{l}\text { Location Cost Index } \\
\text { (RS Means 2010) }\end{array}$ & $91 \%$ & $87 \%$ & $89 \%$ & $89 \%$ & $108 \%$ & $107 \%$ & $124 \%$ & $92 \%$ & $89 \%$ & $105 \%$ & $116 \%$ & $94 \%$ & $112 \%$ & $88 \%$ & $106 \%$ & $121 \%$ \\
\hline TOTAL & $\$ 13,535$ & $\$ 9,588$ & $\$ 9,850$ & $\$ 9,682$ & $\$ 13,631$ & $\$ 7,942$ & $\$ 18,147$ & $\$ 9,920$ & $\$ 10,996$ & $\$ 15,231$ & $\$ 29,568$ & $\$ 13,461$ & $\$ 28,258$ & $\$ 25,599$ & $\$ 25,793$ & $\$ 34,440$ \\
\hline
\end{tabular}

Table 6.12. Incremental Costs for the HVAC EEM Package - Maximum Incremental Cost

\begin{tabular}{|c|c|c|c|c|c|c|c|c|c|c|c|c|c|c|c|c|}
\hline & $1 \mathrm{~A}$ & $2 \mathrm{~A}$ & $2 B$ & $3 \mathrm{~A}$ & 3B-CA & 3B-other & $3 \mathrm{C}$ & $4 \mathrm{~A}$ & $4 \mathrm{~B}$ & $4 \mathrm{C}$ & $5 \mathrm{~A}$ & $5 \mathrm{~B}$ & $6 \mathrm{~A}$ & $6 \mathrm{~B}$ & 7 & 8 \\
\hline Component & Miami & Houston & Phoenix & Atlanta & $\begin{array}{c}\text { Los } \\
\text { Angeles }\end{array}$ & $\begin{array}{c}\text { Las } \\
\text { Vegas }\end{array}$ & $\begin{array}{c}\text { San } \\
\text { Francisco }\end{array}$ & Baltimore & Albuquerque & Seattle & Chicago & Denver & Minneapolis & Helena & Duluth & Fairbanks \\
\hline $\begin{array}{l}\text { HVAC System \& } \\
\text { Controls }\end{array}$ & $\$ 13,860$ & $\$ 10,003$ & $\$ 10,075$ & $\$ 9,873$ & $\$ 11,591$ & $\$ 6,413$ & $\$ 13,628$ & $\$ 9,729$ & $\$ 11,353$ & $\$ 13,531$ & $\$ 29,459$ & $\$ 13,244$ & $\$ 29,314$ & $\$ 33,027$ & $\$ 28,395$ & $\$ 32,551$ \\
\hline Service Water Heater & \multicolumn{16}{|c|}{$\$ 8,500$} \\
\hline Sub-total & $\$ 22,360$ & $\$ 18,503$ & $\$ 18,575$ & $\$ 18,373$ & $\$ 20,091$ & $\$ 14,913$ & $\$ 22,128$ & $\$ 18,229$ & $\$ 19,853$ & $\$ 22,031$ & $\$ 37,959$ & $\$ 21,744$ & $\$ 37,814$ & $\$ 41,527$ & $\$ 36,895$ & $\$ 41,051$ \\
\hline $\begin{array}{l}\text { Location Cost Index } \\
\text { (RS Means 2010) }\end{array}$ & $91 \%$ & $87 \%$ & $89 \%$ & $89 \%$ & $108 \%$ & $107 \%$ & $124 \%$ & $92 \%$ & $89 \%$ & $105 \%$ & $116 \%$ & $94 \%$ & $112 \%$ & $88 \%$ & $106 \%$ & $121 \%$ \\
\hline TOTAL & $\$ 20,325$ & $\$ 16,079$ & $\$ 16,476$ & $\$ 16,315$ & $\$ 21,699$ & $\$ 15,912$ & $\$ 27,395$ & $\$ 16,807$ & $\$ 17,629$ & $\$ 23,045$ & $\$ 44,033$ & $\$ 20,505$ & $\$ 42,163$ & $\$ 36,585$ & $\$ 38,961$ & $\$ 49,466$ \\
\hline
\end{tabular}


Table 6.13. Simple Payback Period for HVAC EEM Package - Minimum Incremental Cost

\begin{tabular}{|c|c|c|c|c|c|c|}
\hline \multirow[b]{2}{*}{$\begin{array}{c}\text { Climate } \\
\text { Zone }\end{array}$} & \multirow[b]{2}{*}{ City } & \multirow[b]{2}{*}{ Incremental Cost } & \multicolumn{3}{|c|}{ Energy Cost Savings } & \multirow{2}{*}{$\begin{array}{l}\text { Simple } \\
\text { Payback } \\
\text { (Years) }\end{array}$} \\
\hline & & & Electricity & Natural Gas & Total & \\
\hline $1 \mathrm{~A}$ & Miami & $\$ 13,535$ & $\$ 4,463$ & $\$ 814$ & $\$ 5,277$ & 2.6 \\
\hline $2 \mathrm{~A}$ & Houston & $\$ 9,588$ & $\$ 4,510$ & $\$ 1,696$ & $\$ 6,206$ & 1.5 \\
\hline $2 \mathrm{~B}$ & Phoenix & $\$ 9,850$ & $\$ 3,638$ & $\$ 1,358$ & $\$ 4,995$ & 2.0 \\
\hline $3 \mathrm{~A}$ & Atlanta & $\$ 9,682$ & $\$ 3,659$ & $\$ 2,526$ & $\$ 6,185$ & 1.6 \\
\hline $3 \mathrm{~B}$ & Los Angeles & $\$ 13,631$ & $\$ 1,482$ & $\$ 1,411$ & $\$ 2,892$ & 4.7 \\
\hline $3 \mathrm{~B}$ & Las Vegas & $\$ 7,942$ & $\$ 2,948$ & $\$ 1,776$ & $\$ 4,724$ & 1.7 \\
\hline $3 \mathrm{C}$ & San Fran. & $\$ 18,147$ & $\$ 1,263$ & $\$ 2,386$ & $\$ 3,649$ & 5.0 \\
\hline $4 \mathrm{~A}$ & Baltimore & $\$ 9,920$ & $\$ 3,065$ & $\$ 3,973$ & $\$ 7,038$ & 1.4 \\
\hline $4 \mathrm{~B}$ & Albuquerque & $\$ 10,996$ & $\$ 1,752$ & $\$ 2,652$ & $\$ 4,404$ & 2.5 \\
\hline $4 \mathrm{C}$ & Seattle & $\$ 15,231$ & $\$ 1,258$ & $\$ 3,398$ & $\$ 4,656$ & 3.3 \\
\hline $5 \mathrm{~A}$ & Chicago & $\$ 29,568$ & $\$ 405$ & $\$ 5,782$ & $\$ 6,186$ & 4.8 \\
\hline $5 \mathrm{~B}$ & Denver & $\$ 13,461$ & $\$ 1,609$ & $\$ 3,730$ & $\$ 5,339$ & 2.5 \\
\hline $6 \mathrm{~A}$ & Minneapolis & $\$ 28,258$ & $\$ 351$ & $\$ 7,557$ & $\$ 7,908$ & 3.6 \\
\hline $6 \mathrm{~B}$ & Helena & $\$ 25,599$ & $(\$ 250)$ & $\$ 5,866$ & $\$ 5,616$ & 4.6 \\
\hline 7 & Duluth & $\$ 25,793$ & $(\$ 131)$ & $\$ 9,156$ & $\$ 9,025$ & 2.9 \\
\hline 8 & Fairbanks & $\$ 34,440$ & $(\$ 201)$ & $\$ 14,024$ & $\$ 13,823$ & 2.5 \\
\hline
\end{tabular}

Table 6.14. Simple Payback Period for HVAC EEM Package - Maximum Incremental Cost

\begin{tabular}{clccccc}
\hline \multirow{2}{*}{$\begin{array}{c}\text { Climate } \\
\text { Zone }\end{array}$} & \multicolumn{1}{c}{ City } & Incremental & \multicolumn{3}{c}{ Energy Cost Savings } & \multicolumn{2}{c}{$\begin{array}{c}\text { Simple } \\
\text { Payback } \\
\text { Cost }\end{array}$} & Years) & Electricity & Natural Gas & Total & (Yeary \\
\cline { 3 - 6 } 1A & Miami & $\$ 20,325$ & $\$ 4,463$ & $\$ 814$ & $\$ 5,277$ & 3.9 \\
2A & Houston & $\$ 16,079$ & $\$ 4,510$ & $\$ 1,696$ & $\$ 6,206$ & 2.6 \\
2B & Phoenix & $\$ 16,476$ & $\$ 3,638$ & $\$ 1,358$ & $\$ 4,995$ & 3.3 \\
3A & Atlanta & $\$ 16,315$ & $\$ 3,659$ & $\$ 2,526$ & $\$ 6,185$ & 2.6 \\
3B & Los Angeles & $\$ 21,699$ & $\$ 1,482$ & $\$ 1,411$ & $\$ 2,892$ & 7.5 \\
3B & Las Vegas & $\$ 15,912$ & $\$ 2,948$ & $\$ 1,776$ & $\$ 4,724$ & 3.4 \\
3C & San Fran. & $\$ 27,395$ & $\$ 1,263$ & $\$ 2,386$ & $\$ 3,649$ & 7.5 \\
4A & Baltimore & $\$ 16,807$ & $\$ 3,065$ & $\$ 3,973$ & $\$ 7,038$ & 2.4 \\
4B & Albuquerque & $\$ 17,629$ & $\$ 1,752$ & $\$ 2,652$ & $\$ 4,404$ & 4.0 \\
4C & Seattle & $\$ 23,045$ & $\$ 1,258$ & $\$ 3,398$ & $\$ 4,656$ & 4.9 \\
5A & Chicago & $\$ 44,033$ & $\$ 405$ & $\$ 5,782$ & $\$ 6,186$ & 7.1 \\
5B & Denver & $\$ 20,505$ & $\$ 1,609$ & $\$ 3,730$ & $\$ 5,339$ & 3.8 \\
6A & Minneapolis & $\$ 42,163$ & $\$ 351$ & $\$ 7,557$ & $\$ 7,908$ & 5.3 \\
6B & Helena & $\$ 36,585$ & $(\$ 250)$ & $\$ 5,866$ & $\$ 5,616$ & 6.5 \\
7 & Duluth & $\$ 38,961$ & $(\$ 131)$ & $\$ 9,156$ & $\$ 9,025$ & 4.3 \\
8 & Fairbanks & $\$ 49,466$ & $(\$ 201)$ & $\$ 14,024$ & $\$ 13,823$ & 3.6 \\
\hline
\end{tabular}

The national weighted average payback period for the mechanical systems EEM package is 3.4 years, which makes its payback period slightly longer when compared to the kitchen EEM package. It is recommended that when opting for the kitchen appliance EEM package, the mechanical systems EEM package should also be implemented as the combination is likely to provide greater energy savings while yielding a relatively short payback. 


\subsection{A Perspective on Costs for Advanced Buildings}

As interest in high-performance buildings grows, so does the desire to understand the real costs of associated EEMs. Any effort such as the one documented in this TSD is inevitably faced with the challenge of finding credible sources of cost data, particularly when some of the more advanced EEMs are being considered. The sources for cost information include widely published data (e.g., R.S. Means, engineering consulting firm and contractor budget estimates, code development sources such as the SSPC 90.1 Cost database, or data found on websites and in testimonials). Clearly it would be desirable to have more robust costs for all measures. Unfortunately, cost information is not consistently available with the same degree of accuracy. When confronted with conflicting or ambiguous costs, the general approach is to take the conservative view of not underestimating the costs so that an inflated assessment of the costeffectiveness of the EEMs is avoided. Conversely, every effort is made to not unduly burden the analysis with costs that are systematically too high, thus biasing the results against undertaking advanced energy design projects.

This study scope does not include more detailed financial analysis. Simple payback is a limited measure of cost effectiveness and does not account for other operating costs, such as maintenance, or for other factors, such as energy price escalation. The result of the cost analysis done in this study is a reasonable estimate of simple payback values for the four advanced EEM packages in the 16 locations, showing that the packages do not create an unreasonably high economic burden in achieving the $44.9 \%$ energy saving. 


\subsection{Reference}

Akbari, H., L. Rainer, et al. (1993). Measured Commercial Load Shapes and Energy-use Intensities and Validation of the LBL End-use Disaggregation Algorithm. Final Report. United States.

ANSI/ASHRAE (2004). Standard 62.1-2004 Ventilation for Acceptable Indoor Air Quality. Atlanta, GA, American Society of Heating, Refrigerating and Air-Conditioning Engineers.

ANSI/ASHRAE/IESNA (1999). Standard 90.1-1999 Energy Standard for Buildings Except Low-rise Residential Buildings. ASHRAE Standard. Atlanta, United States, Amer. Soc. Heating, Ref. AirConditoning Eng. Inc.

ANSI/ASHRAE/IESNA (2004). Standard 90.1-2004 Energy Standard for Buildings Except Low-rise Residential Buildings. ASHRAE Standard. Atlanta, United States, Amer. Soc. Heating, Ref. AirConditoning Eng. Inc.

ASHRAE (2009). ASHRAE handbook fundamentals. Atlanta, GA., ASHRAE.

Bonnema, E., I. Doebber, et al. (2010). Technical Support Document: The Development of the Advanced Energy Design Guide for Small Hospitals and Healthcare Facilities - 30\% Energy Savings.

Golden, CO, National Renewable Energy Laboratory.

Briggs, R. S., R. G. Lucas, et al. (2003). Climate Classification for Building Energy Codes and Standards: Part 1 - Development Process. ASHRAE 2003 Winter Meeting CD, Technical and Symposium Papers, January 1, 2003 - January 1, 2003, Chicago, IL, United states, Amer. Soc. Heating, Ref. Air-Conditoning Eng. Inc.

CBECS (2003). 2003 Commercial Buildings Energy Consumption Survey. CBECS Public Use Microdata Files, Energy Information Administration.

CEC (2006). California Commercial End-Use Survey. Prepared For California Energy Commission by Itron. Sacramento, CA, California Energy Commission (CEC).

CEC. (2010). "Appliances Database - Central Air Conditioners." Retrieved March, 2010, from http://www.appliances.energy.ca.gov/.

Claar, C. N., R. P. Mazzucchi, et al. (1985). The Project on Restaurant Energy Performance - End-Use Monitoring and Analysis. Richland, WA, Pacific Northwest National Laboratory.

Delagah, A. and D. R. Fisher (2010). Energy Efficiency Potential of Gas-Fired Commercial Water Heating Equipment in Foodservice Facilities. PIER Energy-Technologies Program. Sacramento, California, California Energy Commission.

Deru, M. and P. Torcellini (2007). Source Energy and Emission Factors for Energy Use in Buildings. Golden, Colorado, National Renewable Energy Laboratory.

DiLouie, C. (2009). "CLTC Study Demonstrates Major Energy Savings for Bilevel Occupancy Sensors." Retrieved September, 2010, from http://www.aboutlightingcontrols.org/education/papers/2009/2009_bilevel_study.shtml. 
DOE. (2009). "Buildings Energy Data Book." Retrieved August, 2010, from http://buildingsdatabook.eren.doe.gov/.

DOE. (2010a). "Commercial Reference Buildings." Retrieved September, 2010, from http://www1.eere.energy.gov/buildings/commercial_initiative/reference_buildings.html.

DOE. (2010b). "EnergyPlus Energy Simulation Software." Retrieved August, 2010, from http://apps1.eere.energy.gov/buildings/energyplus/.

ECW (2010). Evaluation of the Market Impact of the ASHRAE Advanced Energy Design Guides. Prepared by Energy Center of Wisconsin under contract to ASHRAE. Madison, WI, Energy Center of Wisconsin.

EIA. (2007). "Annual Energy Review. Energy Rate Values in Use by SSPC 90.1." Retrieved March 26, 2007, from http://www.eia.doe.gov/emeu/aer.

Emmerich, S. J., T. McDowell, et al. (2005). Investigation of the Impact of Commercial Building Envelope Airtightness on HVAC Energy Use. Gaithersburg, Maryland, National Institute of Standards and Technology.

EnergyStar. (2010). "Commercial Kitchen Package for Businesses and Operators." Retrieved September 2010, from http://www.energystar.gov/index.cfm?fuseaction=find_a_product.showProductGroup\&pgw_code $=\mathrm{CKP}$.

EPRI (1995). Foodservice Equipment Applications Handbook Palo Alto, California, Electric Power Research Institute.

Fisher, D., R. Swierczyna, et al. (2008). Revised Heat Gain and Capture and Containment Exhaust Rates from Typical Commercial Cooking Appliances.

FSTC (2003). US Range RGTSA Gas Griddle Performance Test. San Ramon, CA, Food Service Technology Center.

FSTC (2007). Energy Efficiency Potential of Gas-Fired Water Heating Systems in a Quick Service Restaurant: An Emerging Technology Field Monitoring Study. San Ramon, CA, Food Service Technology Center.

FSTC. (2010a). "Appliance Technology Assessment." Retrieved September 2010, from http://www.fishnick.com/equipment/techassessment/.

FSTC. (2010b). "Foodservice Equipment Rebates." Retrieved September 2010, from http://www.fishnick.com/saveenergy/rebates/.

ICC (2009). International Mechanical Code 2009. Country Club Hills, International Code Council.

Jarnagin, R., B. Liu, et al. (2006). Technical Support Document: Development of the Advanced Energy Design Guide for Small Office Buildings. Richland, WA, Pacific Northwest National Laboratory. 
Jarnagin, R. E. and G. K. Bandyopadhyay (2010). Weighting Factors for the Commercial Building Prototypes Used in the Development of ANSI/ASHRAE/IESNA Standard 90.1-2010. Richland, WA, Pacific Northwest National Laboratory.

Jiang, W., K. Gowri, et al. (2009). Technical Support Document: 50\% Energy Savings Design Technology Packages for Highway Lodging Buildings. Richland, WA, Pacific Northwest National Laboratory.

Jiang, W., RE Jarnagin, et al. (2008). Technical Support Document: The Development of the Advanced Energy Design Guide for Highway Lodging Buildings. Richland, WA, Pacific Northwest National Laboratory.

Konopacki, S. J. and H. Akbari (2001). Measured Energy Savings and Demand Reduction from A Reflective Roof Membrane on A Large Retail Store in Austin.

LBNL. (2010a). "Cool Roofing Materials Database." Lawrence Berkley National Laboratory Retrieved August, 2010, from http://eetd.lbl.gov/coolroofs/.

LBNL. (2010b). "Radiance Ray-tracing Software." Retrieved March, 2010, from http://radsite.lbl.gov/radiance/HOME.html.

Liu, B., R. Jarnagin, et al. (2007). Technical Support Document: The Development of the Advanced Energy Design Guide for Small Warehouse and Self-Storage Buildings Richland, WA, Pacific Northwest National Laboratory.

Liu, B., R. Jarnagin, et al. (2006). Technical Support Document: The Development of the Advanced Energy Design Guide for Small Retail Buildings. Richland, WA, Pacific Northwest National Laboratory.

LRC (2004). Reducing Barriers to Use of High Efficiency lighting. Final Report Year 3. Troy, New York, Lighting Research Center, Rensselaer Polytechnic Institute.

Pless, S., P. Torcellini, et al. (2007). Technical Support Document: The Development of the Advanced Energy Design Guide for K-12 Schools - 30\% Energy Savings. Golden, CO, National Renewable Energy Laboratory.

PNNL (2004). Technical Support Document: Energy Efficiency Program for Commercial and Industrial Equipment: Advanced Notice of Proposed Rulemaking for Commercial Unitary Air Conditioners and Heat Pumps. Washington D.C, U.S. Department of Energy: pp. 6-1 to 6-60.

R.S.Means (2010). Building Cost Data. Kingston, MA, RSMeans.

Reinhart, C. F. (2010). "Daysim 3.0." Retrieved March, 2010, from http://www.daysim.com/download.html.

Richman, E. E., E. Rauch, et al. (2008). National Commercial Construction Characteristics and Compliance with Building Energy Codes: 1999-2007. 2008 ACEEE Summer Study on Energy Efficiency in Buildings, ACEEE Publications. Washington D.C.

Scarpa (2010). Equipment Upgrades Spark Menu, Daypart Growth. National Restaurant News. 44. 
Smith, V. A., D. R. Fisher, et al. (2001). Estimating food service loads and profiles, Cincinnati, OH, United states, Amer. Soc. Heating, Ref. Air-Conditoning Eng. Inc.

Swami, H. V. and S. Chandra (1987). Procedures for Calculating Natural Ventilation Airflow Rates in Buildings. Cape Canaveral, Florida, Florida Solar Energy Center.

Thornton, B., W. Wang, et al. (2010). Technical Support Document: 50\% Energy Savings for Small Office Buildings. Richland, WA, Pacific Northwest National Laboratory.

Thornton, B., W. Wang, et al. (2009). Technical Support Document: 50\% Energy Savings Design Technology Packages for Medium Office Buildings. Richland, WA, Pacific Northwest National Laboratory.

VonNeida, B., D. Maniccia, et al. (2001). An Analysis of the Energy and Cost Savings Potential of Occupancy Sensors for Commercial Lighting Systems. Journal of the Illuminating Engineering Society 30(Compendex): 111-122.

Wassmer, M. R. and M. J. Brandemuehl (2006). Effect of Data Availability on Modeling of Residential Air Conditioners and Heat Pumps for Energy Calculations. 2006 Winter Meeting of the American Society of Heating, Refrigerating and Air-Conditioning Engineers, ASHRAE, January 21, 2006 - January 25, 2006, Chicago, IL, United states, Amer. Soc. Heating, Ref. AirConditoning Eng. Inc.

Winiarski, D., M. Halverson, et al. (2007). Analysis of Building Envelope Construction in 2003 CBECS Post-1980 Buildings. Richland, WA, Pacific Northwest National Laboratory. 
Appendix A

\section{Energy Performance of QSRs with Alternative Baseline HVAC Configurations (Option B)}




\section{Appendix A}

\section{Energy Performance of QSRs with Alternative Baseline HVAC Configurations (Option B)}

The description of the alternative baseline HVAC configuration (Option B) is presented in Section 3.4 and the schematic of the system is shown in Figure 3.10. As addressed in Section 3.4, because of its limited applicability and popularity, Option B was not used as the baseline to evaluate the energy saving potential of the EEMs in this report. Another reason is that, in real applications, various discharge air temperature set points ranging from $55^{\circ} \mathrm{F}$ to $70^{\circ} \mathrm{F}\left(13^{\circ} \mathrm{C}\right.$ to $\left.21^{\circ} \mathrm{C}\right)$ have been used for the kitchen makeup air unit in winter. Although the selection is supposed to be climate dependent, there does not seem to be a consensus on the selection in the design community. The authors feel that it may be informative to show the energy simulation result of baseline Option B with three discharge air temperature set-point settings. Compared to the baseline Option A model results, only HVAC related energy end uses (i.e., the supply fan, cooling, and heating) are different in Option B. Therefore, the other energy end-use results are not presented again. Comparisons of the energy use for six representative cities (Houston, Atlanta, Los Angles, Baltimore, Chicago, and Denver) are shown in Figures A.1 to A.6.

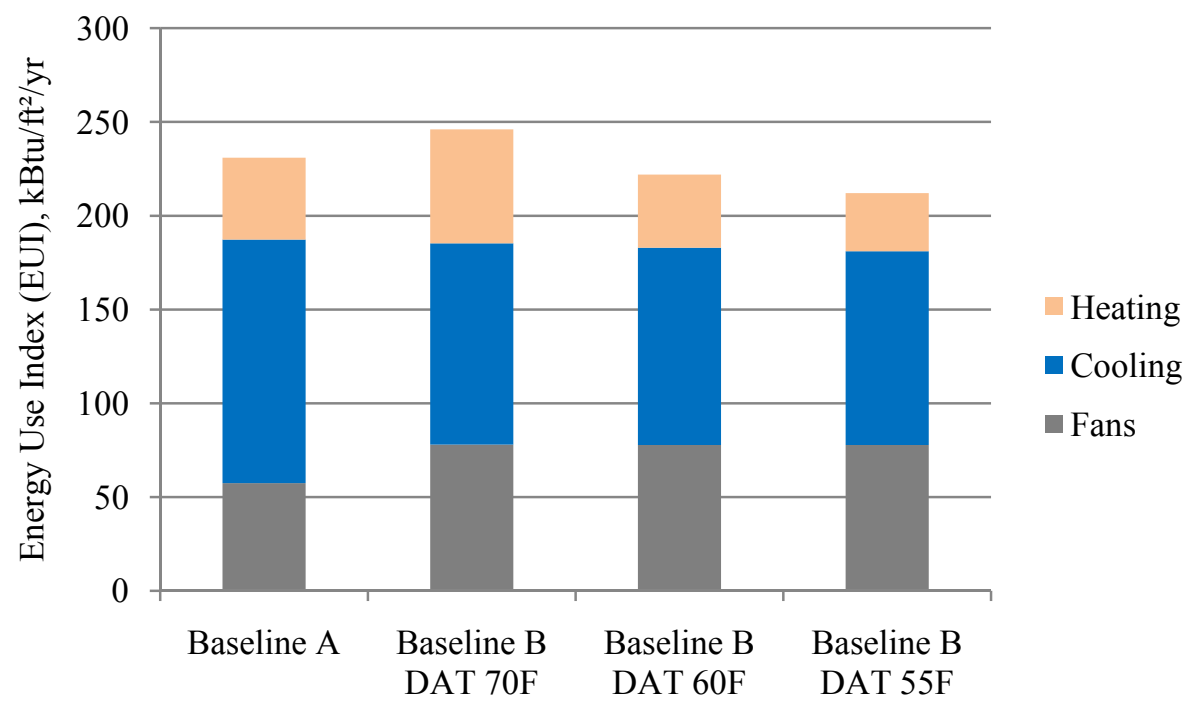

Figure A.1. Comparison of Selected HVAC-Related EUIs, Houston 


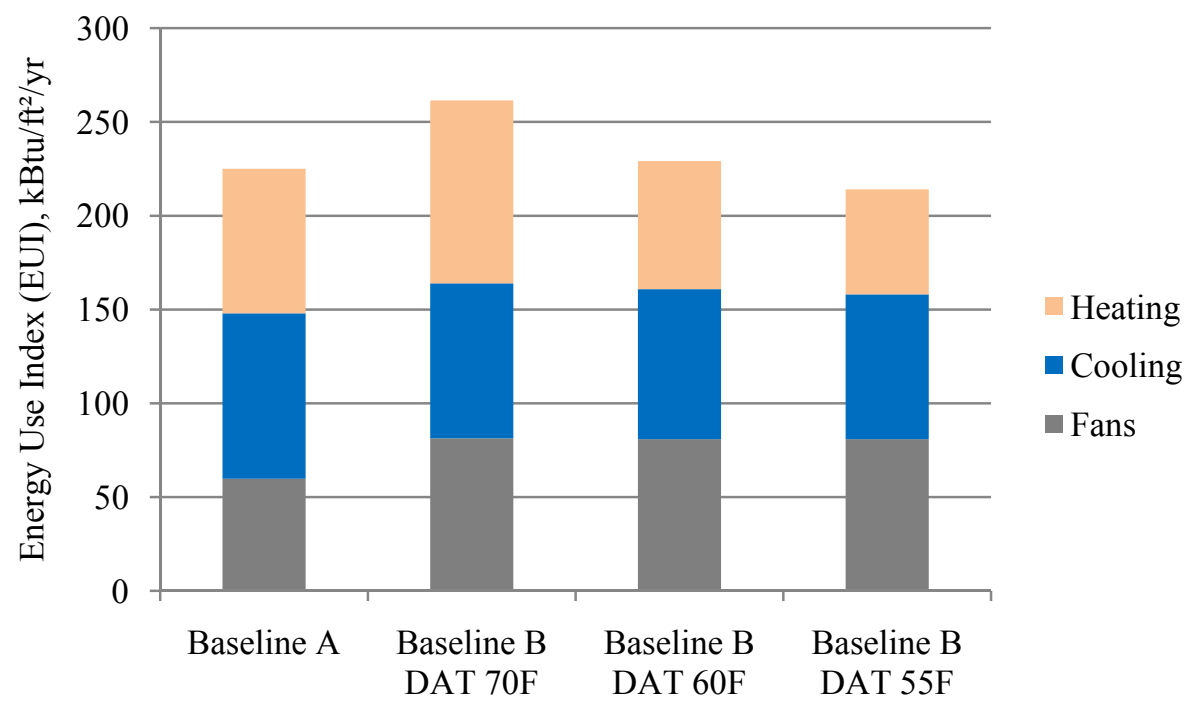

Figure A.2. Comparison of Selected HVAC-Related EUIs, Atlanta

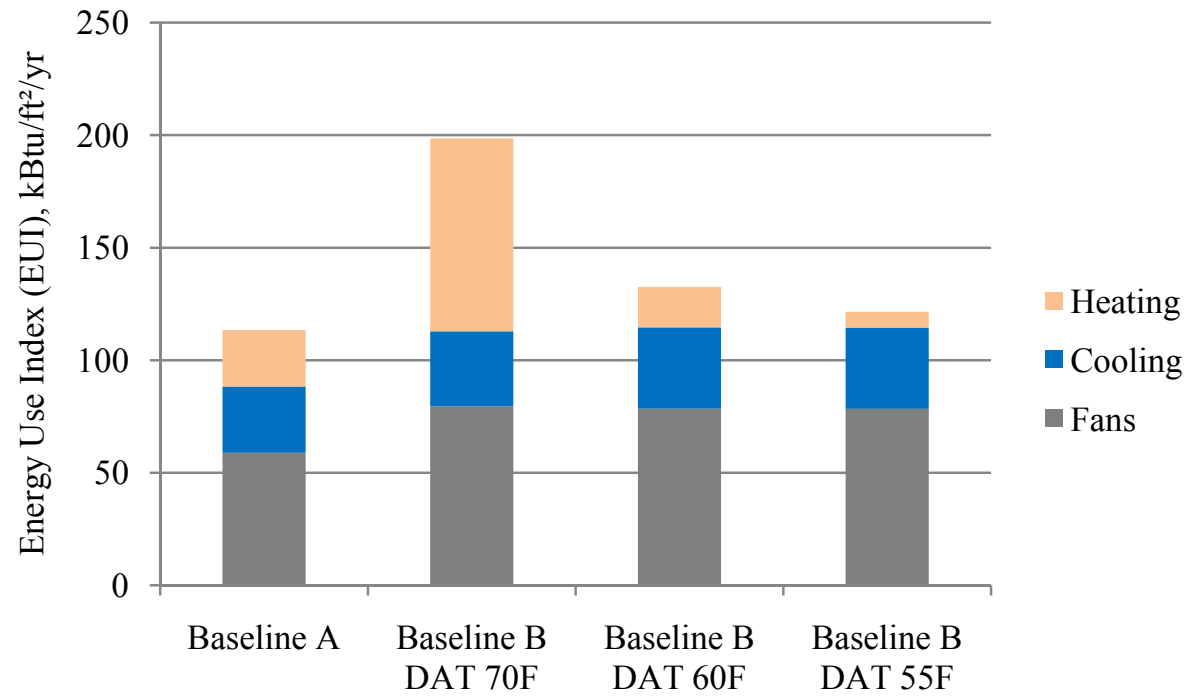

Figure A.3. Comparison of Selected HVAC-Related EUIs, Los Angles 


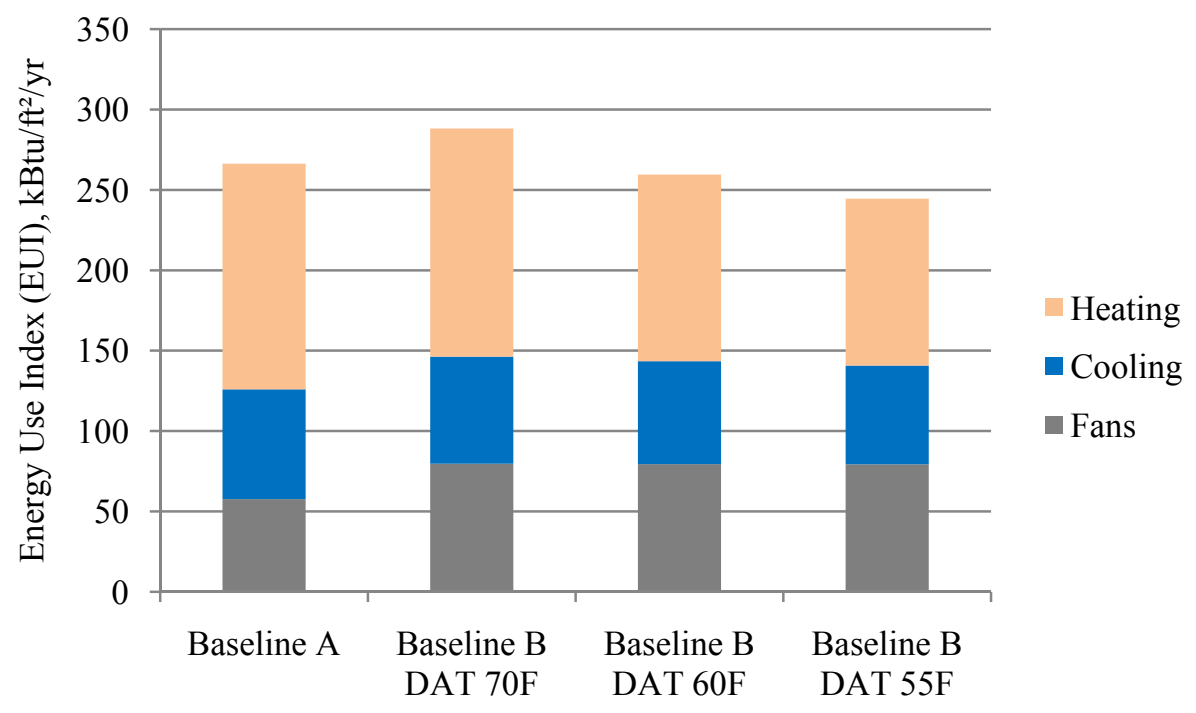

Figure A.4. Comparison of Selected HVAC-Related EUIs, Baltimore

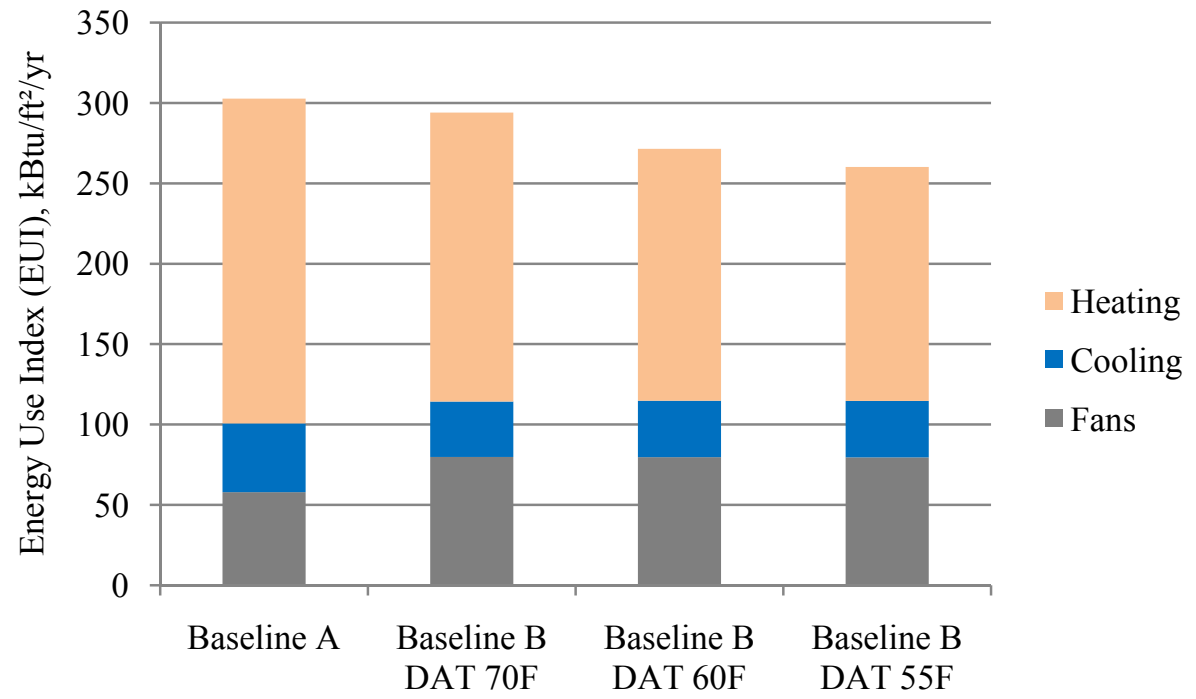

Figure A.5. Comparison of Selected HVAC-Related EUIs, Chicago 


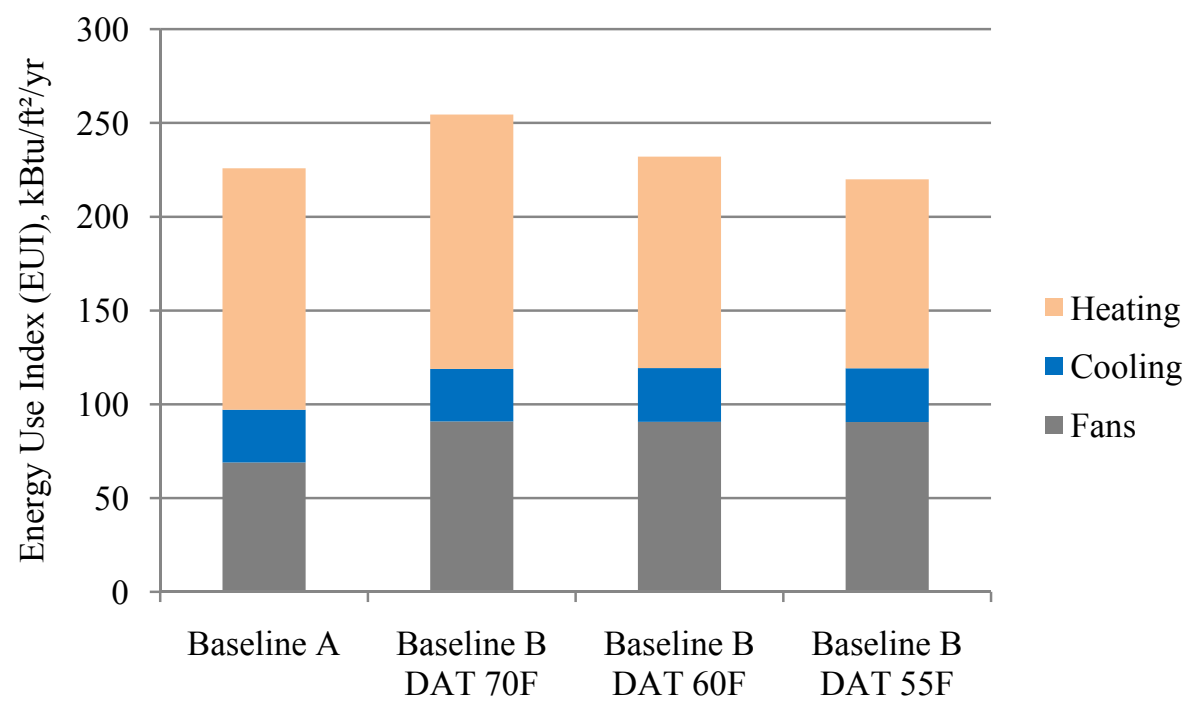

Figure A.6. Comparison of Selected HVAC-Related EUIs, Denver 


\section{Appendix B}

\section{Energy Modeling Inputs}




\section{Appendix B}

\section{Energy Modeling Inputs}

Table B.1. Baseline and Advanced Model Inputs for QSR IP Units

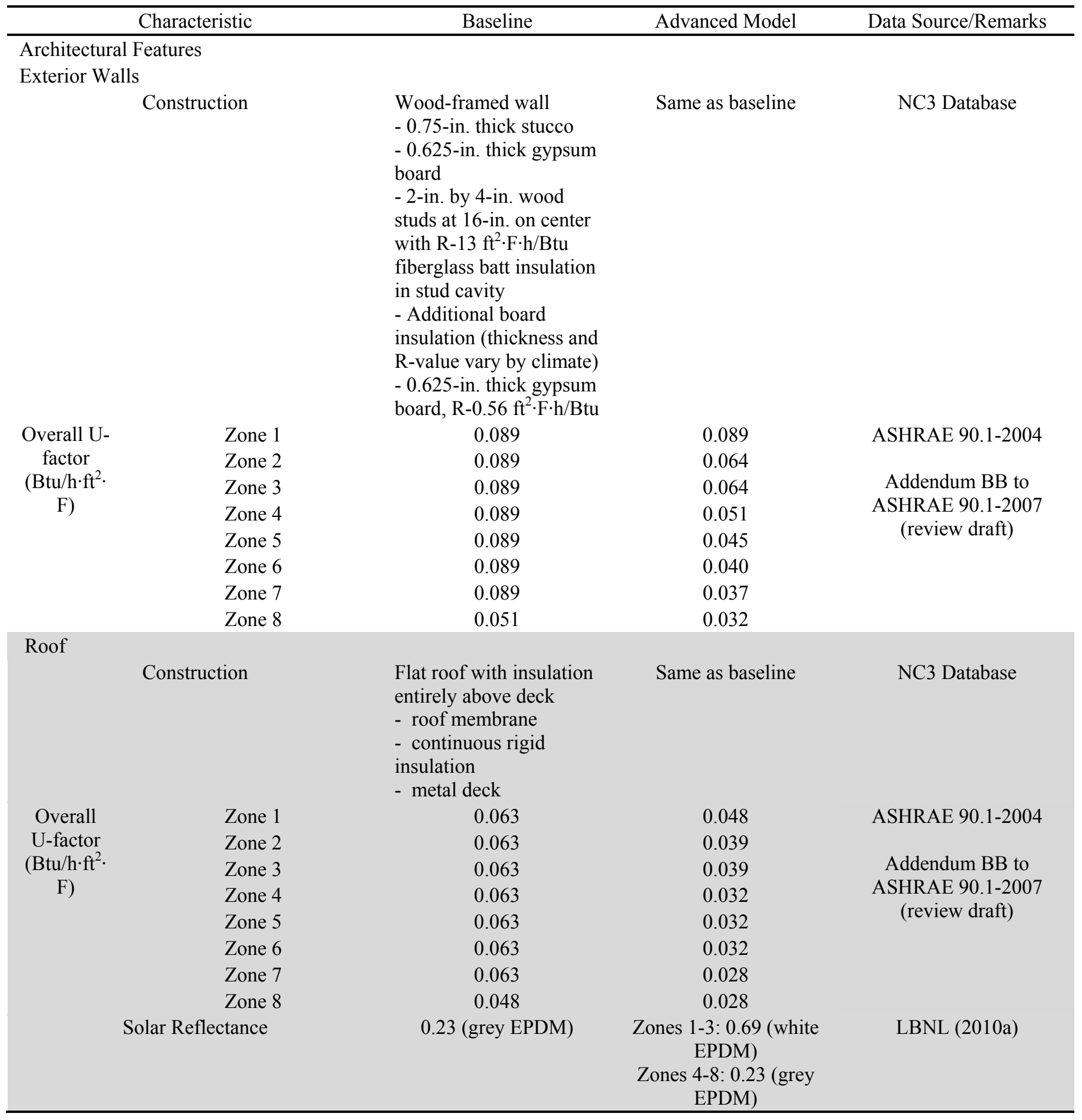


Table B.1. (contd)

\begin{tabular}{|c|c|c|c|c|}
\hline & Characteristic & Baseline & Advanced Model & Data Source/Remarks \\
\hline Slab-on-Gro & ade Floor & & & \\
\hline & Construction & $\begin{array}{l}\text { Concrete slab on earth } \\
\text { - carpet pad } \\
\text { - 6-in. concrete }\end{array}$ & Same as baseline & $\begin{array}{l}\text { CBECS } 2003 \\
\text { NC3 Database }\end{array}$ \\
\hline & $\begin{array}{c}\text { Floor F-factor } \\
(\mathrm{Btu} / \mathrm{h} \cdot \mathrm{ft} \cdot \mathrm{F})\end{array}$ & $\begin{array}{l}\text { Zones 1-7: } 0.730 \\
\text { Zone } 8: 0.540\end{array}$ & $\begin{array}{l}\text { Zones 1-3: } 0.730 \\
\text { Zones 4-5: } 0.520 \\
\text { Zones 6-7: } 0.510 \\
\text { Zone 8: } 0.434\end{array}$ & $\begin{array}{l}\text { ASHRAE 90.1-2004 } \\
\text { Addendum BB to } \\
\text { ASHRAE 90.1-2007 } \\
\text { (review draft) }\end{array}$ \\
\hline Fenestration & & & & \\
\hline & Window-to-wall ratio & $\begin{array}{l}\text { East: } 0.13 \\
\text { North: } 0 \\
\text { West: } 0.13 \\
\text { South: } 0.34 \\
\text { All: } 0.14\end{array}$ & Same as baseline & $\begin{array}{l}\text { CBECS } 2003 \\
\text { NC3 Database }\end{array}$ \\
\hline Actual & Zone 1 & 1.21 & 0.80 & ASHRAE 90.1-2004 \\
\hline selected & Zone 2 & 1.21 & 0.57 & Addendum BB to \\
\hline window U- & Zone 3A, 3B & 0.57 & 0.55 & 90.1-2007 (review \\
\hline factor & Zone $3 \mathrm{C}$ & 1.21 & 0.55 & draft) \\
\hline$(\mathrm{Btu} / \mathrm{h} \bullet \mathrm{ft} 2 \bullet$ & Zone 4 & 0.58 & 0.45 & Window type chosen \\
\hline & Zone 5 & 0.58 & 0.45 & $\begin{array}{l}\text { from hypothetical glass } \\
\text { library in EneravPlus }\end{array}$ \\
\hline & Zone 6 & 0.58 & 0.47 & \\
\hline & Zone 7 & 0.57 & 0.47 & \\
\hline & Zone 8 & 0.45 & 0.44 & \\
\hline Actual & Zone 1 & 0.25 & 0.25 & ASHRAE 90.1-2004 \\
\hline selected & Zone 2 & 0.25 & 0.25 & Addendum BB to \\
\hline window & Zone 3A, 3B & 0.25 & 0.25 & 90.1-2007 (review \\
\hline SHGC & Zone $3 \mathrm{C}$ & 0.39 & 0.25 & draft) \\
\hline & Zone 4 & 0.39 & 0.28 & Window type chosen \\
\hline & Zone 5 & 0.39 & 0.29 & $\begin{array}{l}\text { from hypothetical glass } \\
\text { library in EnerayPlus }\end{array}$ \\
\hline & Zone 6 & 0.39 & 0.35 & \\
\hline & Zone 7 & 0.49 & 0.40 & \\
\hline & Zone 8 & 0.45 & 0.40 & \\
\hline Actual & Zone 1 & 1.0 & 1.3 & ASHRAE 90.1-2004 \\
\hline selected & Zone 2 & 1.0 & 1.0 & Addendum BB to \\
\hline window & Zone $3 \mathrm{~A}, 3 \mathrm{~B}$ & 1.0 & 1.3 & 90.1-2007 (review \\
\hline VT/SHGC & Zone $3 \mathrm{C}$ & 1.0 & 1.3 & draft) \\
\hline & Zone 4 & 1.0 & 1.1 & Window type chosen \\
\hline & Zone 5 & 1.0 & 1.1 & $\begin{array}{l}\text { from hypothetical glass } \\
\text { library in EneravPlus }\end{array}$ \\
\hline & Zone 6 & 1.0 & 1.1 & \\
\hline & Zone 7 & 1.0 & 1.1 & \\
\hline & Zone 8 & 1.0 & 1.1 & \\
\hline
\end{tabular}


Table B.1. (contd)

\begin{tabular}{|c|c|c|c|c|}
\hline \multicolumn{2}{|r|}{ Characteristic } & Baseline & Advanced Model & Data Source/Remarks \\
\hline \multicolumn{5}{|c|}{ Internal Loads } \\
\hline \multicolumn{5}{|l|}{ Occupancy } \\
\hline & People & $\begin{array}{l}88 \text { in dining zone } \\
6 \text { in kitchen zone }\end{array}$ & Same as baseline & \multirow[t]{2}{*}{$\begin{array}{l}\text { ASHRAE Standard } \\
62.1-2004\end{array}$} \\
\hline & Schedule & See Table B. 3 & Same as baseline & \\
\hline \multicolumn{5}{|l|}{ Lighting } \\
\hline \multicolumn{2}{|c|}{ Peak LPD $\left(\mathrm{W} / \mathrm{ft}^{2}\right)$} & 1.44 & 0.83 & $\begin{array}{l}\text { ASHRAE 90.1-2004 } \\
\text { Lighting design and } \\
\text { calculation (see TSD } \\
\text { Section 4.2.1.1 and } \\
3.2 .2 \text { ) }\end{array}$ \\
\hline \multicolumn{2}{|c|}{ Occupancy sensors } & No & \multicolumn{2}{|l|}{ Yes } \\
\hline \multicolumn{2}{|c|}{ Daylight harvesting } & No & \multicolumn{2}{|l|}{$\begin{array}{l}\text { - Continuous dimming } \\
\text { - Illuminance set point: } \\
30 \text { foot candles } \\
\text { - Minimum input power } \\
\text { fraction: } 0.6 \\
- \text { Minimum light output } \\
\text { fraction: } 0.15\end{array}$} \\
\hline Schedule & & See Table B. 3 & See Table B.4 & \\
\hline \multicolumn{5}{|c|}{ Cooking appliances } \\
\hline \multirow{21}{*}{$\begin{array}{l}\text { Capacity } \\
\text { (W) }\end{array}$} & Griddle & 52,706 & 69,950 & \multirow{21}{*}{$\begin{array}{c}\text { See Table B. } 3 \text { for } \\
\text { schedules }\end{array}$} \\
\hline & Fryers & 142,891 & 105,412 & \\
\hline & Airpot Coffee Brewer & 351 & 158 & \\
\hline & Juice Dispenser & 240 & 240 & \\
\hline & Milk Shake Dispenser & 585 & 585 & \\
\hline & Ice Cream Dispenser & 585 & 585 & \\
\hline & Heat Lamp & 2,900 & 2,900 & \\
\hline & Holding Cabinets & 2,625 & 225 & \\
\hline & Microwave & 340 & 340 & \\
\hline & Conveyor Toaster & 3,572 & 3,572 & \\
\hline & Coffee Warmer & 90 & N/A & \\
\hline & $1 / 2$ size Convection Oven & 2,200 & 1,200 & \\
\hline & Reach-In Refrigator & 275 & 150 & \\
\hline & Reach-in Freezer & 492 & 250 & \\
\hline & Undercounter Refrigerator & 250 & 140 & \\
\hline & Undercounter Freezer & 328 & 260 & \\
\hline & Refrigerated Prep Table & 810 & 250 & \\
\hline & Ice Machine & 3,000 & 600 & \\
\hline & Remote Condenser & N/A & 2,400 & \\
\hline & Walk-in cooler & 650 & 440 & \\
\hline & walk-in freezer & 1,500 & 1,020 & \\
\hline
\end{tabular}


Table B.1. (contd)

\begin{tabular}{|c|c|c|c|}
\hline Characteristic & Baseline & Advanced Model & Data Source/Remarks \\
\hline \multicolumn{4}{|l|}{ HVAC System } \\
\hline \multicolumn{4}{|l|}{ System type } \\
\hline Heating/ Cooling & $\begin{array}{l}\text { Packaged single zone } \\
\text { CAV system } \\
\text { - DX packaged air } \\
\text { conditioning unit for } \\
\text { cooling } \\
\text { - gas furnace for heating }\end{array}$ & $\begin{array}{l}\text { Packaged single zone } \\
\text { CAV system } \\
\text { - X packaged air } \\
\text { conditioning unit for } \\
\text { cooling } \\
\text { - gas furnace for heating } \\
\text { - Dedicated outdoor air } \\
\text { system provide } \\
\text { ventilation and } \\
\text { secondary heating and } \\
\text { cooling }\end{array}$ & CBECS 2003 \\
\hline \multicolumn{4}{|l|}{ HVAC efficiency } \\
\hline Cooling efficiency & $\begin{array}{l}\text { DX cooling coil } \\
\text { - COP=3.23-3.91, } \\
\text { depending on the sized } \\
\text { capacity } \\
\text { - performance curves } \\
\text { see Table B.5 }\end{array}$ & $\begin{array}{l}\text { DX cooling coil } \\
\text { - COP }=3.90-4.31 \text {, } \\
\text { depending on the sized } \\
\text { capacity } \\
\text { - performance curves } \\
\text { same as baseline }\end{array}$ & $\begin{array}{l}\text { ASHRAE 90.1-2004 } \\
\text { ASHRAE 90.1-2007 } \\
\text { Appliances database of } \\
\text { California Energy } \\
\text { Commission. } \\
\text { Manufacturers' } \\
\text { Catalog }\end{array}$ \\
\hline Heating efficiency & $\begin{array}{l}\text { Gas furnace } \\
\text { - burner efficiency } \\
=0.78 \text { (capacity } \leq 225 \\
\mathrm{kBtu} / \mathrm{h}) ;=0.80 \text { (capacity } \\
>225 \mathrm{kBtu} / \mathrm{h})\end{array}$ & Same as baseline & $\begin{array}{l}\text { ASHRAE 90.1-2004 } \\
\text { ASHRAE 90.1-2007 }\end{array}$ \\
\hline \multicolumn{4}{|l|}{ HVAC control } \\
\hline $\begin{array}{l}\text { Thermostat setpoint }\left({ }^{\circ} \mathrm{F}\right) \\
\text { Air system }\end{array}$ & $\begin{array}{l}\text { See Table B. } 2 \\
\text { - Supply air } \\
\text { temperature: } 55^{\circ} \mathrm{F} \\
\text { minimum }\end{array}$ & $\begin{array}{l}\text { Same as baseline } \\
\text { Same as baseline }\end{array}$ & $\begin{array}{l}\text { Design practice } \\
\text { Design practice }\end{array}$ \\
\hline \multicolumn{4}{|l|}{ Ventilation } \\
\hline Heat recovery & No & $\begin{array}{l}\text { - Runaround loop heat } \\
\text { exchanger is used for } \\
\text { heat recovery in a few } \\
\text { climate zones } \\
\text { - Heat recovery } \\
\text { effectiveness } 0.45\end{array}$ & $\begin{array}{l}\text { Selection of cities is } \\
\text { based on test runs. } \\
\text { Efficiency is based on } \\
\text { design experience }\end{array}$ \\
\hline Economizer & $\begin{array}{l}\text { Differential dry bulb } \\
\text { based economizer in } \\
\text { some locations }\end{array}$ & $\begin{array}{l}\text { Extended use of } \\
\text { differential dry bulb } \\
\text { based economizer in } \\
\text { some locations }\end{array}$ & $\begin{array}{l}\text { ASHRAE 90.1-2004 } \\
\text { Addendum CY to } \\
\text { ASHRAE 90.1-2007 }\end{array}$ \\
\hline
\end{tabular}


Table B.1. (contd)

\begin{tabular}{|c|c|c|c|}
\hline Characteristic & Baseline & Advanced Model & Data Source/Remarks \\
\hline \multicolumn{4}{|l|}{ Fan System } \\
\hline Supply fan & $\begin{array}{l}\text { - Constant speed fan } \\
\text { - Fan mechanical } \\
\text { efficiency: } 55 \% \\
\text { - Fan motor efficiency } \\
\text { based on motor power } \\
\text { from Standard 90.1- } \\
2004 \text {. }\end{array}$ & $\begin{array}{l}\text { - Constant speed fan } \\
\text { - Fan mechanical } \\
\text { efficiency: } 65 \% \\
\text { - Fan motor efficiency } \\
\text { based on motor power } \\
\text { from Standard 90.1- } \\
2004 \text {. }\end{array}$ & \\
\hline Exhaust/return fan & $\begin{array}{l}\text { Modeled as plug load, } \\
78 \mathrm{~W} \text { for restroom } \\
\text { exhaust fan, } 562 \mathrm{~W} \text { for } \\
\text { each of the two kitchen } \\
\text { exhaust fans }\end{array}$ & $\begin{array}{l}\text { modeled as plug load, } \\
78 \mathrm{~W} \text { for restroom } \\
\text { exhaust fan, } 106 \mathrm{~W} \text { and } \\
73 \mathrm{~W} \text { for two kitchen } \\
\text { exhaust fans } \\
\text { The schedule due to } \\
\text { demand-controlled } \\
\text { ventilation is in Table } \\
\text { B.3 }\end{array}$ & \\
\hline Fan system static pressure & 2.5 in. w.c & $\begin{array}{l}\text { - } 2.5 \text { in. w.c } \\
\text { - Additional } 1 \text { in. w.c } \\
\text { pressure drop for heat } \\
\text { recovery }\end{array}$ & $\begin{array}{l}\text { See TSD Section 3.4.6 } \\
\text { and } 4.4 .3\end{array}$ \\
\hline \multicolumn{4}{|l|}{ SHW System } \\
\hline Gas-fired water heater & $\begin{array}{l}\text { - Conventional type with } \\
\text { thermal efficiency }=80 \% \\
\text { - Tank volume }=100 \\
\text { gallon } \\
\text { - Standby heat loss } \\
\text { coefficient }=13.7 \mathrm{Btu} / \mathrm{h} \text { - } \\
{ }^{\circ} \mathrm{F}\end{array}$ & $\begin{array}{l}\text { - Condensing water } \\
\text { heater with thermal } \\
\text { efficiency }=95 \% \text {. } \\
\text { - Tank volume }=100 \\
\text { gallon } \\
\text { - Standby heat loss } \\
\text { coefficient }=13.7 \mathrm{Btu} / \mathrm{h}- \\
{ }^{\circ} \mathrm{F}\end{array}$ & $\begin{array}{l}\text { ASHRAE 90.1-2004 } \\
\text { Manufacturers' } \\
\text { Catalog }\end{array}$ \\
\hline
\end{tabular}


Table B.2. Baseline and Advanced Model Inputs for QSR SI Units

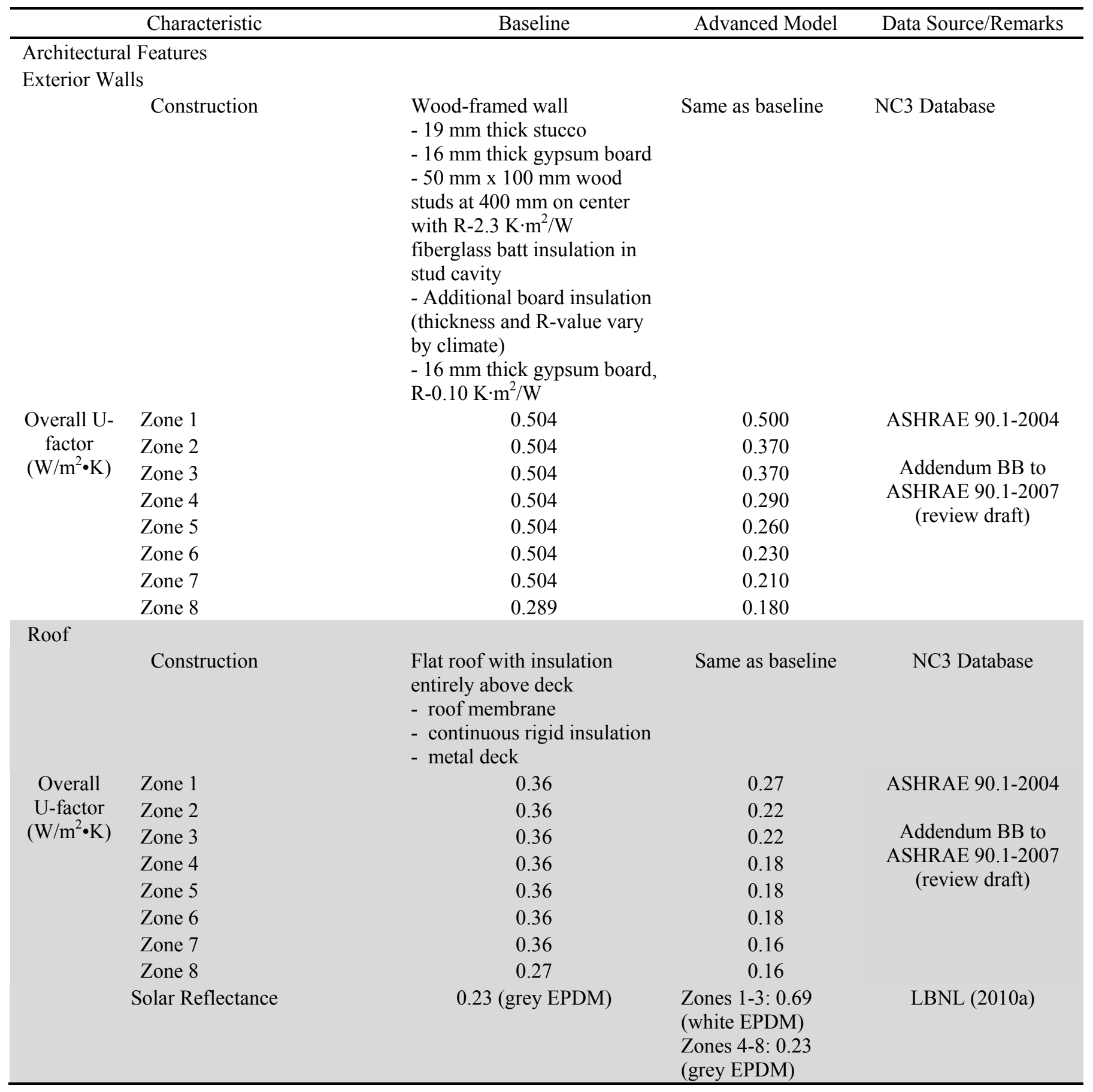


Table B.2. (contd)

\begin{tabular}{|c|c|c|c|c|}
\hline & Characteristic & Baseline & Advanced Model & Data Source/Remarks \\
\hline \multicolumn{5}{|c|}{ Slab-on-Grade Floor } \\
\hline \multicolumn{2}{|c|}{ Construction } & $\begin{array}{l}\text { Concrete slab on earth } \\
\text { - carpet pad } \\
\text { - } 150 \text {-mm. concrete }\end{array}$ & Same as baseline & $\begin{array}{l}\text { CBECS } 2003 \\
\text { NC3 Database }\end{array}$ \\
\hline & $\begin{array}{l}\text { Floor F-factor } \\
\quad(\mathrm{W} / \mathrm{m} \bullet \mathrm{K})\end{array}$ & $\begin{array}{l}\text { Zones 1-7: } 1.264 \\
\text { Zone } 8: 0.935\end{array}$ & $\begin{array}{l}\text { Zones 1-3: } 1.26 \\
\text { Zones 4-5: } 0.90 \\
\text { Zones 6-7: } 0.88 \\
\text { Zone 8: } 0.75\end{array}$ & $\begin{array}{l}\text { ASHRAE 90.1-2004 } \\
\text { Addendum BB to } \\
\text { ASHRAE 90.1-2007 } \\
\text { (review draft) }\end{array}$ \\
\hline \multicolumn{5}{|c|}{ Fenestration } \\
\hline \multicolumn{2}{|c|}{ Window-to-wall ratio } & $\begin{array}{l}\text { East: } 0.13 \\
\text { North: } 0 \\
\text { West: } 0.13 \\
\text { South: } 0.34 \\
\text { All: } 0.14\end{array}$ & Same as baseline & $\begin{array}{l}\text { CBECS } 2003 \\
\text { NC3 Database }\end{array}$ \\
\hline \multirow{9}{*}{$\begin{array}{c}\text { Actual } \\
\text { selected } \\
\text { window U- } \\
\text { factor } \\
\left(\mathrm{W} / \mathrm{m}^{2}{ }^{\circ} \mathrm{C}\right)\end{array}$} & Zone 1 & 6.87 & 4.54 & \multirow{9}{*}{$\begin{array}{l}\text { ASHRAE 90.1-2004 } \\
\text { Addendum BB to } \\
\text { 90.1-2007 (review } \\
\text { draft) } \\
\text { Window type chosen } \\
\text { from hypothetical glass } \\
\text { library in EnergyPlus }\end{array}$} \\
\hline & Zone 2 & 6.87 & 3.24 & \\
\hline & Zone $3 \mathrm{~A}, 3 \mathrm{~B}$ & 3.24 & 3.12 & \\
\hline & Zone $3 \mathrm{C}$ & 6.87 & 3.12 & \\
\hline & Zone 4 & 3.29 & 2.56 & \\
\hline & Zone 5 & 3.29 & 2.56 & \\
\hline & Zone 6 & 3.29 & 2.67 & \\
\hline & Zone 7 & 3.24 & 2.67 & \\
\hline & Zone 8 & 2.56 & 2.5 & \\
\hline \multirow{9}{*}{$\begin{array}{l}\text { Actual } \\
\text { selected } \\
\text { window } \\
\text { SHGC }\end{array}$} & Zone 1 & 0.25 & 0.25 & \multirow{9}{*}{$\begin{array}{l}\text { ASHRAE 90.1-2004 } \\
\text { Addendum BB to } \\
\text { 90.1-2007 (review } \\
\text { draft) } \\
\text { Window type chosen } \\
\text { from hypothetical glass } \\
\text { library in EnergyPlus }\end{array}$} \\
\hline & Zone 2 & 0.25 & 0.25 & \\
\hline & Zone $3 \mathrm{~A}, 3 \mathrm{~B}$ & 0.25 & 0.25 & \\
\hline & Zone $3 \mathrm{C}$ & 0.39 & 0.25 & \\
\hline & Zone 4 & 0.39 & 0.28 & \\
\hline & Zone 5 & 0.39 & 0.29 & \\
\hline & Zone 6 & 0.39 & 0.35 & \\
\hline & Zone 7 & 0.49 & 0.40 & \\
\hline & Zone 8 & 0.45 & 0.40 & \\
\hline \multirow{9}{*}{$\begin{array}{c}\text { Actual } \\
\text { selected } \\
\text { window } \\
\text { VT/SHGC }\end{array}$} & Zone 1 & 1.0 & 1.3 & \multirow{9}{*}{$\begin{array}{l}\text { ASHRAE 90.1-2004 } \\
\text { Addendum BB to 90.1- } \\
2007 \text { (review draft) } \\
\text { Window type chosen } \\
\text { from hypothetical glass } \\
\text { library in EnergyPlus }\end{array}$} \\
\hline & Zone 2 & 1.0 & 1.0 & \\
\hline & Zone $3 \mathrm{~A}, 3 \mathrm{~B}$ & 1.0 & 1.3 & \\
\hline & Zone 3C & 1.0 & 1.3 & \\
\hline & Zone 4 & 1.0 & 1.1 & \\
\hline & Zone 5 & 1.0 & 1.1 & \\
\hline & Zone 6 & 1.0 & 1.1 & \\
\hline & Zone 7 & 1.0 & 1.1 & \\
\hline & Zone 8 & 1.0 & 1.1 & \\
\hline
\end{tabular}


Table B.2. (contd)

\begin{tabular}{|c|c|c|c|c|}
\hline & Characteristic & Baseline & Advanced Model & Data Source/Remarks \\
\hline Internal Lc & & & & \\
\hline Occupancy & & & & \\
\hline & People & $\begin{array}{l}88 \text { in dining zone } \\
6 \text { in kitchen zone }\end{array}$ & Same as baseline & $\begin{array}{l}\text { ASHRAE Standard } \\
62.1-2004\end{array}$ \\
\hline & Schedule & See Table B.2 & Same as baseline & \\
\hline Lighting & & & & \\
\hline Peak LPD & $\left.\mathrm{V} / \mathrm{m}^{2}\right)$ & 15.49 & 8.96 & $\begin{array}{l}\text { ASHRAE 90.1-2004 } \\
\text { Lighting design and } \\
\text { calculation (see TSD } \\
\text { Section 4.2.1.1 and } \\
3.2 .2 \text { ) }\end{array}$ \\
\hline Occupancy & ensors & No & Yes & \\
\hline Daylight $h$ & jesting & No & $\begin{array}{l}\text { - Continuous } \\
\text { dimming } \\
\text { - Illuminance } \\
\text { setpoint: } 375 \text { lux } \\
\text { - Minimum input } \\
\text { power fraction: } 0.6 \\
\text { - Minimum light } \\
\text { output fraction: } \\
0.15\end{array}$ & \\
\hline Schedule & & See Table B. 3 & See Table B.4 & \\
\hline Capacity & Griddle & 180,000 & 238,891 & See Table B. 3 for \\
\hline$(\mathrm{W})$ & Fryers & 488,000 & 360,000 & schedules \\
\hline & Airpot Coffee Brewer & 1,199 & 538 & \\
\hline & Juice Dispenser & 820 & 820 & \\
\hline & Milk Shake Dispenser & 1,998 & 1,998 & \\
\hline & Ice Cream Dispenser & 1,998 & 1,998 & \\
\hline & Heat Lamp & 9,904 & 9,904 & \\
\hline & Holding Cabinets & 8,965 & 768 & \\
\hline & Microwave & 1,161 & 1,161 & \\
\hline & Conveyor Toaster & 12,199 & 12,199 & \\
\hline & Coffee Warmer & 307 & N/A & \\
\hline & 1/2 size Convection Oven & 7,513 & 4,098 & \\
\hline & Reach-In Refrigator & 939 & 512 & \\
\hline & Reach-in Freezer & 1,680 & 854 & \\
\hline & Undercounter Refrigerator & 854 & 478 & \\
\hline & Undercounter Freezer & 1,120 & 888 & \\
\hline & Refrigerated Prep Table & 2,766 & 854 & \\
\hline & Ice Machine & 10,246 & 2,049 & \\
\hline & Remote Condenser & N/A & 8,196 & \\
\hline & Walk-in cooler & 2,220 & 1,503 & \\
\hline & walk-in freezer & 5,123 & 3,483 & \\
\hline
\end{tabular}


Table B.2. (contd)

\begin{tabular}{|c|c|c|c|}
\hline Characteristic & Baseline & Advanced Model & Data Source/Remarks \\
\hline \multicolumn{4}{|l|}{ HVAC System } \\
\hline \multicolumn{4}{|l|}{ System type } \\
\hline Heating/Cooling & $\begin{array}{l}\text { Packaged single zone CAV } \\
\text { system } \\
\text { - DX packaged air } \\
\text { conditioning unit for cooling } \\
\text { - gas furnace for heating }\end{array}$ & $\begin{array}{l}\text { Packaged single } \\
\text { zone CAV system } \\
\text { - DX packaged air } \\
\text { conditioning unit } \\
\text { for cooling } \\
\text { - gas furnace for } \\
\text { heating } \\
\text { - Dedicated } \\
\text { outdoor air system } \\
\text { provide ventilation } \\
\text { and secondary } \\
\text { heating and cooling }\end{array}$ & CBECS 2003 \\
\hline \multicolumn{4}{|l|}{ HVAC efficiency } \\
\hline Cooling efficiency & $\begin{array}{l}\text { DX cooling coil } \\
\text { - COP=3.23-3.91, depending } \\
\text { on the sized capacity } \\
\text { - performance curves see } \\
\text { Table B.5 }\end{array}$ & $\begin{array}{l}\text { DX cooling coil } \\
\text { - COP=3.90-4.31, } \\
\text { depending on the } \\
\text { sized capacity } \\
\text { - performance } \\
\text { curves same as } \\
\text { baseline }\end{array}$ & $\begin{array}{l}\text { ASHRAE 90.1-2004 } \\
\text { ASHRAE 90.1-2007 } \\
\text { Appliances database of } \\
\text { California Energy } \\
\text { Commission. } \\
\text { Manufacturers' } \\
\text { Catalog }\end{array}$ \\
\hline Heating efficiency & $\begin{array}{l}\text { Gas furnace } \\
-\quad \text { burner efficiency }=0.78 \\
(\text { capacity } \leq 66 \mathrm{~kW}) ;=0.80 \\
(\text { capacity }>66 \mathrm{~kW})\end{array}$ & Same as baseline & $\begin{array}{l}\text { ASHRAE 90.1-2004 } \\
\text { ASHRAE 90.1-2007 }\end{array}$ \\
\hline \multicolumn{4}{|l|}{ HVAC control } \\
\hline Thermostat setpoint $\left({ }^{\circ} \mathrm{C}\right)$ & See Table B.3 & Same as baseline & Design practice \\
\hline Air system & $\begin{array}{l}\text { - Supply air temperature: } \\
12.8^{\circ} \mathrm{C} \text { minimum }\end{array}$ & Same as baseline & Design practice \\
\hline \multicolumn{4}{|l|}{ Ventilation } \\
\hline Heat recovery & No & $\begin{array}{l}\text { - Runaround loop } \\
\text { heat exchanger is } \\
\text { used for heat } \\
\text { recovery in a few } \\
\text { climate zones } \\
\text { - Heat recovery } \\
\text { effectiveness } 0.45\end{array}$ & $\begin{array}{l}\text { Selection of cities is } \\
\text { based on test runs. } \\
\text { Efficiency is based on } \\
\text { design experience }\end{array}$ \\
\hline Economizer & $\begin{array}{l}\text { Differential dry bulb based } \\
\text { economizer in some } \\
\text { locations }\end{array}$ & $\begin{array}{l}\text { Extended use of } \\
\text { differential dry bulb } \\
\text { based economizer } \\
\text { in some locations }\end{array}$ & $\begin{array}{l}\text { ASHRAE 90.1-2004 } \\
\text { Addendum CY to } \\
\text { ASHRAE 90.1-2007 }\end{array}$ \\
\hline
\end{tabular}


Table B.2. (contd)

\begin{tabular}{|c|c|c|c|}
\hline Characteristic & Baseline & Advanced Model & Data Source/Remarks \\
\hline \multicolumn{4}{|l|}{ Fan System } \\
\hline Supply fan & $\begin{array}{l}\text { - Constant speed fan } \\
\text { - Fan mechanical efficiency: } \\
55 \% \\
\text { - Fan motor efficiency based } \\
\text { on motor power from } \\
\text { Standard 90.1-2004. }\end{array}$ & $\begin{array}{l}\text { - Constant speed } \\
\text { fan } \\
\text { - Fan mechanical } \\
\text { efficiency: } 65 \% \\
\text { - Fan motor } \\
\text { efficiency based on } \\
\text { motor power from } \\
\text { Standard } 90.1-2004 \text {. }\end{array}$ & \\
\hline Exhaust/return fan & $\begin{array}{l}\text { Modeled as plug load, } 78 \mathrm{~W} \\
\text { for restroom exhaust fan, } 562 \\
\mathrm{~W} \text { for each of the two } \\
\text { kitchen exhaust fans }\end{array}$ & $\begin{array}{l}\text { Modeled as plug } \\
\text { load, } 78 \mathrm{~W} \text { for } \\
\text { restroom exhaust } \\
\text { fan, } 106 \mathrm{~W} \text { and } 73 \\
\mathrm{~W} \text { for two kitchen } \\
\text { exhaust fans. The } \\
\text { schedule due to } \\
\text { demand-controlled } \\
\text { ventilation is in } \\
\text { Table B.3 }\end{array}$ & \\
\hline Fan system static pressure & $622.5 \mathrm{~Pa}$ & $\begin{array}{l}\text { - } 622.5 \mathrm{~Pa} \\
\text { - Additional } 245 \mathrm{~Pa} \\
\text { pressure drop for } \\
\text { heat recovery }\end{array}$ & $\begin{array}{l}\text { See TSD Section 3.4.6 } \\
\text { and 4.4.3 }\end{array}$ \\
\hline \multicolumn{4}{|l|}{ SHW System } \\
\hline Gas-fired water heater & $\begin{array}{l}\text { - Conventional type with } \\
\text { thermal efficiency }=80 \% \\
\text { - } \text { Tank volume }=379 \mathrm{~L} \\
\text { - Standby heat loss } \\
\text { coefficient }=7.23 \mathrm{~W} / \mathrm{K}\end{array}$ & $\begin{array}{l}\text { - Condensing } \\
\text { water heater with } \\
\text { thermal efficiency }= \\
95 \% \text {. } \\
-\quad \text { Tank volume }= \\
379 \mathrm{~L} \\
-\quad \text { Standby heat loss } \\
\text { coefficient }=7.23 \\
\text { W/K }\end{array}$ & $\begin{array}{l}\text { ASHRAE 90.1-2004 } \\
\text { Manufacturers' } \\
\text { Catalog }\end{array}$ \\
\hline
\end{tabular}


Table B.3. Major Schedules for the Baseline Model

\begin{tabular}{|c|c|c|c|c|c|c|c|c|c|c|c|c|c|c|c|c|c|c|c|c|c|c|c|c|c|}
\hline Schedule & Day Type & 1 & 2 & 3 & 4 & 5 & 6 & 7 & 8 & 9 & 10 & 11 & 12 & 13 & 14 & 15 & 16 & 17 & 18 & 19 & 20 & 21 & 22 & 23 & 24 \\
\hline \multicolumn{26}{|l|}{ Internal Loads Schedules } \\
\hline \multirow{2}{*}{ Lighting (Fraction) } & WD & 0.45 & 0.15 & 0.15 & 0.15 & 0.15 & 0.45 & 0.9 & 0.9 & 0.9 & 0.9 & 0.9 & 0.9 & 0.9 & 0.9 & 0.9 & 0.9 & 0.9 & 0.9 & 0.9 & 0.9 & 0.9 & 0.9 & 0.9 & 0.9 \\
\hline & WKD HOL & 0.45 & 0.15 & 0.15 & 0.15 & 0.15 & 0.15 & 0.45 & 0.9 & 0.9 & 0.9 & 0.9 & 0.9 & 0.9 & 0.9 & 0.9 & 0.9 & 0.9 & 0.9 & 0.9 & 0.9 & 0.9 & 0.9 & 0.9 & 0.9 \\
\hline \multirow{2}{*}{ Griddle (Fraction) } & WD & 0 & 0 & 0 & 0 & 0 & 0.24 & 0.24 & 0.33 & 0.33 & 0.29 & 0.24 & 0.33 & 0.39 & 0.39 & 0.33 & 0.24 & 0.24 & 0.33 & 0.33 & 0.33 & 0.33 & 0.33 & 0.29 & 0.24 \\
\hline & WKD HOL & 0 & 0 & 0 & 0 & 0 & 0.00 & 0.24 & 0.29 & 0.29 & 0.29 & 0.24 & 0.33 & 0.39 & 0.33 & 0.29 & 0.29 & 0.29 & 0.29 & 0.33 & 0.33 & 0.33 & 0.33 & 0.29 & 0.24 \\
\hline \multirow{2}{*}{ Fryer (Fraction) } & WD & 0 & 0 & 0 & 0 & 0 & 0.11 & 0.11 & 0.25 & 0.25 & 0.18 & 0.11 & 0.25 & 0.35 & 0.35 & 0.25 & 0.11 & 0.11 & 0.25 & 0.25 & 0.25 & 0.25 & 0.25 & 0.18 & 0.11 \\
\hline & WKD HOL & 0 & 0 & 0 & 0 & 0 & 0 & 0.11 & 0.18 & 0.18 & 0.18 & 0.11 & 0.25 & 0.35 & 0.25 & 0.18 & 0.18 & 0.18 & 0.18 & 0.25 & 0.25 & 0.25 & 0.25 & 0.18 & 0.11 \\
\hline \multirow{2}{*}{ unhooded appliance A (Fraction) } & WD & 0 & 0 & 0 & 0 & 0 & 1 & 1 & 1 & 1 & 1 & 1 & 1 & 1 & 1 & 1 & 1 & 1 & 1 & 1 & 1 & 1 & 1 & 1 & 1 \\
\hline & WKD HOL & 0 & 0 & 0 & 0 & 0 & 0 & 1 & 1 & 1 & 1 & 1 & 1 & 1 & 1 & 1 & 1 & 1 & 1 & 1 & 1 & 1 & 1 & 1 & 1 \\
\hline \multirow{2}{*}{ unhooded appliance B (Fraction) } & WD & 0 & 0 & 0 & 0 & 0 & 1 & 1 & 1 & 1 & 0.5 & 0 & 0 & 0 & 0 & 0 & 0 & 0 & 0 & 0 & 0 & 0 & 0 & 0 & 0 \\
\hline & WKD HOL & 0 & 0 & 0 & 0 & 0 & 0 & 1 & 1 & 1 & 0.5 & 0 & 0 & 0 & 0 & 0 & 0 & 0 & 0 & 0 & 0 & 0 & 0 & 0 & 0 \\
\hline \multirow{2}{*}{ Occupancy (Fraction) } & WD & 0.05 & 0 & 0 & 0 & 0 & 0.05 & 0.1 & 0.4 & 0.4 & 0.3 & 0.2 & 0.5 & 0.8 & 0.7 & 0.4 & 0.2 & 0.25 & 0.5 & 0.55 & 0.55 & 0.55 & 0.5 & 0.35 & 0.2 \\
\hline & WKD HOL & 0.05 & 0 & 0 & 0 & 0 & 0 & 0.05 & 0.3 & 0.3 & 0.3 & 0.2 & 0.45 & 0.6 & 0.5 & 0.35 & 0.3 & 0.3 & 0.3 & 0.55 & 0.55 & 0.55 & 0.5 & 0.35 & 0.2 \\
\hline \multirow{2}{*}{ Exterior Lighting (Fraction) } & WD & 1 & 1 & 1 & 1 & 1 & 1 & 1 & 1 & 1 & 1 & 1 & 1 & 1 & 1 & 1 & 1 & 1 & 1 & 1 & 1 & 1 & 1 & 1 & 1 \\
\hline & WKD HOL & 1 & 1 & 1 & 1 & 1 & 1 & 1 & 1 & 1 & 1 & 1 & 1 & 1 & 1 & 1 & 1 & 1 & 1 & 1 & 1 & 1 & 1 & 1 & 1 \\
\hline \multicolumn{26}{|l|}{ SHW } \\
\hline \multirow{2}{*}{ Hot water (Fraction) } & WD & 0 & 0 & 0 & 0 & 0 & 0.15 & 0.15 & 0.33 & 0.13 & 0.1 & 0.72 & 0.31 & 0.98 & 0.92 & 0.22 & 0.31 & 0.23 & 0.16 & 0.1 & 0.4 & 0.42 & 0.43 & 0.15 & 0 \\
\hline & WKD HOL & 0 & 0 & 0 & 0 & 0 & 0 & 0.15 & 0.15 & 0.15 & 0.1 & 0.72 & 0.6 & 0.98 & 0.92 & 0.25 & 0.25 & 0.23 & 0.16 & 0.1 & 0.4 & 0.42 & 0.43 & 0.15 & 0 \\
\hline \multicolumn{26}{|l|}{ HVAC Schedules } \\
\hline \multirow{2}{*}{ HVAC system (on/off) } & WD & 1 & 0 & 0 & 0 & 0 & 1 & 1 & 1 & 1 & 1 & 1 & 1 & 1 & 1 & 1 & 1 & 1 & 1 & 1 & 1 & 1 & 1 & 1 & 1 \\
\hline & WKD HOL & 1 & 0 & 0 & 0 & 0 & 0 & 1 & 1 & 1 & 1 & 1 & 1 & 1 & 1 & 1 & 1 & 1 & 1 & 1 & 1 & 1 & 1 & 1 & 1 \\
\hline \multirow{2}{*}{ Heating setpoint $\left({ }^{\circ} \mathrm{F}\right)$} & WD & 70 & 60 & 60 & 60 & 65 & 70 & 70 & 70 & 70 & 70 & 70 & 70 & 70 & 70 & 70 & 70 & 70 & 70 & 70 & 70 & 70 & 70 & 70 & 70 \\
\hline & WKD HOL & 70 & 60 & 60 & 60 & 60 & 65 & 70 & 70 & 70 & 70 & 70 & 70 & 70 & 70 & 70 & 70 & 70 & 70 & 70 & 70 & 70 & 70 & 70 & 70 \\
\hline \multirow{2}{*}{ Cooling setpoint $\left({ }^{\circ} \mathrm{F}\right)$} & WD & 75 & 86 & 86 & 86 & 80 & 75 & 75 & 75 & 75 & 75 & 75 & 75 & 75 & 75 & 75 & 75 & 75 & 75 & 75 & 75 & 75 & 75 & 75 & 75 \\
\hline & WKD HOL & 75 & 86 & 86 & 86 & 86 & 80 & 75 & 75 & 75 & 75 & 75 & 75 & 75 & 75 & 75 & 75 & 75 & 75 & 75 & 75 & 75 & 75 & 75 & 75 \\
\hline
\end{tabular}


Table B.4. Major Schedules for the Advanced Model

\begin{tabular}{|c|c|c|c|c|c|c|c|c|c|c|c|c|c|c|c|c|c|c|c|c|c|c|c|c|c|}
\hline Schedule & Day Type & 1 & 2 & 3 & 4 & 5 & 6 & 7 & 8 & 9 & 10 & 11 & 12 & 13 & 14 & 15 & 16 & 17 & 18 & 19 & 20 & 21 & 22 & 23 & 24 \\
\hline \multicolumn{26}{|l|}{ Internal Loads Schedules } \\
\hline \multirow{2}{*}{ Lighting (Fraction) } & WD & 0.45 & 0.13 & 0.13 & 0.13 & 0.13 & 0.45 & 0.84 & 0.84 & 0.84 & 0.84 & 0.84 & 0.84 & 0.84 & 0.84 & 0.84 & 0.84 & 0.84 & 0.84 & 0.84 & 0.84 & 0.84 & 0.84 & 0.84 & 0.84 \\
\hline & WKD HOL & 0.45 & 0.13 & 0.13 & 0.13 & 0.13 & 0.13 & 0.45 & 0.84 & 0.84 & 0.84 & 0.84 & 0.84 & 0.84 & 0.84 & 0.84 & 0.84 & 0.84 & 0.84 & 0.84 & 0.84 & 0.84 & 0.84 & 0.84 & 0.84 \\
\hline \multirow{2}{*}{ Griddle (Fraction) } & WD & 0 & 0 & 0 & 0 & 0 & 0.12 & 0.12 & 0.17 & 0.17 & 0.16 & 0.12 & 0.17 & 0.25 & 0.25 & 0.17 & 0.12 & 0.12 & 0.17 & 0.17 & 0.17 & 0.17 & 0.17 & 0.16 & 0.12 \\
\hline & WKD HOL & 0 & 0 & 0 & 0 & 0 & 0.00 & 0.12 & 0.16 & 0.16 & 0.16 & 0.12 & 0.17 & 0.25 & 0.17 & 0.16 & 0.16 & 0.16 & 0.16 & 0.17 & 0.17 & 0.17 & 0.17 & 0.16 & 0.12 \\
\hline \multirow{2}{*}{ Fryer (Fraction) } & WD & 0 & 0 & 0 & 0 & 0 & 0.12 & 0.12 & 0.17 & 0.17 & 0.16 & 0.12 & 0.17 & 0.25 & 0.25 & 0.17 & 0.12 & 0.12 & 0.17 & 0.17 & 0.17 & 0.17 & 0.17 & 0.16 & 0.12 \\
\hline & WKD HOL & 0 & 0 & 0 & 0 & 0 & 0.00 & 0.04 & 0.08 & 0.08 & 0.08 & 0.04 & 0.14 & 0.20 & 0.14 & 0.08 & 0.08 & 0.08 & 0.08 & 0.14 & 0.14 & 0.14 & 0.14 & 0.08 & 0.04 \\
\hline \multirow{2}{*}{ unhooded appliance A (Fraction) } & WD & 0 & 0 & 0 & 0 & 0 & 1 & 1 & 1 & 1 & 1 & 1 & 1 & 1 & 1 & 1 & 1 & 1 & 1 & 1 & 1 & 1 & 1 & 1 & 1 \\
\hline & WKD HOL & 0 & 0 & 0 & 0 & 0 & 0 & 1 & 1 & 1 & 1 & 1 & 1 & 1 & 1 & 1 & 1 & 1 & 1 & 1 & 1 & 1 & 1 & 1 & 1 \\
\hline \multirow{2}{*}{ unhooded appliance B (Fraction) } & WD & 0 & 0 & 0 & 0 & 0 & 1 & 1 & 1 & 1 & 0.5 & 0 & 0 & 0 & 0 & 0 & 0 & 0 & 0 & 0 & 0 & 0 & 0 & 0 & 0 \\
\hline & WKD HOL & 0 & 0 & 0 & 0 & 0 & 0 & 1 & 1 & 1 & 0.5 & 0 & 0 & 0 & 0 & 0 & 0 & 0 & 0 & 0 & 0 & 0 & 0 & 0 & 0 \\
\hline \multirow{2}{*}{ Occupancy (Fraction) } & WD & 0.05 & 0 & 0 & 0 & 0 & 0.05 & 0.1 & 0.4 & 0.4 & 0.3 & 0.2 & 0.5 & 0.8 & 0.7 & 0.4 & 0.2 & 0.25 & 0.5 & 0.55 & 0.55 & 0.55 & 0.5 & 0.35 & 0.2 \\
\hline & WKD HOL & 0.05 & 0 & 0 & 0 & 0 & 0 & 0.05 & 0.3 & 0.3 & 0.3 & 0.2 & 0.45 & 0.6 & 0.5 & 0.35 & 0.3 & 0.3 & 0.3 & 0.55 & 0.55 & 0.55 & 0.5 & 0.35 & 0.2 \\
\hline \multirow{2}{*}{ Exterior Lighting (Fraction) } & WD & 1 & 0.48 & 0.48 & 0.48 & 0.48 & 1 & 1 & 1 & 1 & 1 & 1 & 1 & 1 & 1 & 1 & 1 & 1 & 1 & 1 & 1 & 1 & 1 & 1 & 1 \\
\hline & WKD HOL & 1 & 0.48 & 0.48 & 0.48 & 0.48 & 0.48 & 1 & 1 & 1 & 1 & 1 & 1 & 1 & 1 & 1 & 1 & 1 & 1 & 1 & 1 & 1 & 1 & 1 & 1 \\
\hline \multicolumn{26}{|l|}{$\overline{\text { SHW }}$} \\
\hline \multirow{2}{*}{ Hot water (Fraction) } & WD & 0 & 0 & 0 & 0 & 0 & 0.15 & 0.15 & 0.33 & 0.13 & 0.1 & 0.72 & 0.31 & 0.98 & 0.92 & 0.22 & 0.31 & 0.23 & 0.16 & 0.1 & 0.4 & 0.42 & 0.43 & 0.15 & 0 \\
\hline & WKD HOL & 0 & 0 & 0 & 0 & 0 & 0 & 0.15 & 0.15 & 0.15 & 0.1 & 0.72 & 0.6 & 0.98 & 0.92 & 0.25 & 0.25 & 0.23 & 0.16 & 0.1 & 0.4 & 0.42 & 0.43 & 0.15 & 0 \\
\hline \multicolumn{26}{|l|}{ HVAC Schedules } \\
\hline \multirow{2}{*}{ HVAC system (on/off) } & WD & 1 & 0 & 0 & 0 & 0 & 1 & 1 & 1 & 1 & 1 & 1 & 1 & 1 & 1 & 1 & 1 & 1 & 1 & 1 & 1 & 1 & 1 & 1 & 1 \\
\hline & WKD HOL & 1 & 0 & 0 & 0 & 0 & 0 & 1 & 1 & 1 & 1 & 1 & 1 & 1 & 1 & 1 & 1 & 1 & 1 & 1 & 1 & 1 & 1 & 1 & 1 \\
\hline \multirow{2}{*}{ Heating setpoint $\left({ }^{\circ} \mathrm{F}\right)$} & WD & 70 & 60 & 60 & 60 & 65 & 70 & 70 & 70 & 70 & 70 & 70 & 70 & 70 & 70 & 70 & 70 & 70 & 70 & 70 & 70 & 70 & 70 & 70 & 70 \\
\hline & WKD HOL & 70 & 60 & 60 & 60 & 60 & 65 & 70 & 70 & 70 & 70 & 70 & 70 & 70 & 70 & 70 & 70 & 70 & 70 & 70 & 70 & 70 & 70 & 70 & 70 \\
\hline \multirow{2}{*}{ Cooling setpoint $\left({ }^{\circ} \mathrm{F}\right)$} & WD & 75 & 86 & 86 & 86 & 80 & 75 & 75 & 75 & 75 & 75 & 75 & 75 & 75 & 75 & 75 & 75 & 75 & 75 & 75 & 75 & 75 & 75 & 75 & 75 \\
\hline & WKD HOL & 75 & 86 & 86 & 86 & 86 & 80 & 75 & 75 & 75 & 75 & 75 & 75 & 75 & 75 & 75 & 75 & 75 & 75 & 75 & 75 & 75 & 75 & 75 & 75 \\
\hline \multirow{2}{*}{ Kitchen exhaust flow (Fraction) } & WD & 0 & 0 & 0 & 0 & 0 & 0.74 & 0.74 & 0.83 & 0.83 & 0.82 & 0.74 & 0.83 & 0.99 & 0.99 & 0.83 & 0.74 & 0.74 & 0.83 & 0.83 & 0.83 & 0.83 & 0.83 & 0.82 & 0.74 \\
\hline & WKD HOL & 0 & 0 & 0 & 0 & 0 & 0 & 0.64 & 0.72 & 0.72 & 0.72 & 0.64 & 0.79 & 0.94 & 0.79 & 0.72 & 0.72 & 0.72 & 0.72 & 0.79 & 0.79 & 0.79 & 0.79 & 0.72 & 0.64 \\
\hline
\end{tabular}


Table B.5. Performance Curves for the DX Coils Used in the Packaged CAV System

\begin{tabular}{|c|c|c|c|c|c|c|}
\hline \multirow[b]{2}{*}{ curve name } & \multicolumn{6}{|c|}{ coefficients } \\
\hline & $\mathrm{a}$ & $\mathrm{b}$ & $\mathrm{c}$ & $\mathrm{d}$ & $\mathrm{e}$ & $\mathrm{f}$ \\
\hline Total cooling capacity modifier function of temperature & & & & & & \\
\hline $\operatorname{Cap}\left(T_{w b, i}, T_{c, i}\right)=a+b\left(T_{w b, i}\right)+c\left(T_{w b, i}\right)^{2}+d\left(T_{c, i}\right)+e\left(T_{c, i}\right)^{2}+f\left(T_{w b, i}\right)\left(T_{c, i}\right)$ & 0.42415 & 0.04426 & -0.00042 & 0.00333 & -0.00008 & -0.00021 \\
\hline $\begin{array}{l}\text { Total cooling capacity modifier function of flow fraction } \\
C a p(f f)=a+b(f f)+c(f f)^{2}\end{array}$ & 0.77136 & 0.34053 & -0.11088 & - & - & - \\
\hline $\begin{array}{l}\text { EIR modifier function of temperature } \\
\qquad E I R\left(T_{w b, i}, T_{c, i}\right)=a+b\left(T_{w b, i}\right)+c\left(T_{w b, i}\right)^{2}+d\left(T_{c, i}\right)+e\left(T_{c, i}\right)^{2}+f\left(T_{w b, i}\right)\left(T_{c, i}\right)\end{array}$ & 1.23649 & -0.02431 & 0.00057 & -0.01434 & 0.00063 & -0.00038 \\
\hline $\begin{array}{l}\text { EIR modifier function of flow fraction } \\
E I R(f f)=a+b(f f)+c(f f)^{2}\end{array}$ & 1.20550 & -0.32953 & 0.12308 & - & - & - \\
\hline $\begin{array}{l}\text { Part load correction function } \\
P L F(P L R)=a+b(P L R)+c(P L R)^{2}\end{array}$ & 0.771 & 0.229 & 0 & - & - & - \\
\hline $\begin{array}{l}T_{w b, i}-\text { wet-bulb temperature of the air entering the cooling coil }\left({ }^{\circ} \mathrm{C}\right) \\
T_{c, i}-\text { dry-bulb temperature of the air entering the air-cooled condenser }( \\
f f-\text { the ratio of the actual airflow rate across the cooling coil to the rate } \\
P L F-\text { part load ratio (the ratio between actual sensible cooling load and }\end{array}$ & $\begin{array}{l}\text { C) } \\
\text { air flow } \\
\text { he rated } \mathrm{s}\end{array}$ & ite & & & & \\
\hline
\end{tabular}




\section{Appendix C}

Review Comments and Responses on the Draft TSD Report 


\section{Appendix C}

\section{Review Comments and Responses on the Draft TSD Report}

\begin{tabular}{|c|c|c|c|c|c|}
\hline No. & Category & Section & Comment & PNNL Response & PNNL Action \\
\hline 1 & $\begin{array}{l}\text { Baseline } \\
\text { Cooking } \\
\text { Energy } \\
\text { Use }\end{array}$ & $\begin{array}{l}\text { Section 4.1.2 Estimating Cooking Energy Use } \\
\text { "The food preparation energy end use intensity data } \\
\text { is estimated from a post data analysis process" }\end{array}$ & $\begin{array}{l}\text { This should be described } \\
\text { in some detail (or is it } \\
\text { elsewhere in the report? } \\
\text { If so, then there should be } \\
\text { a reference made to that } \\
\text { section.) }\end{array}$ & $\begin{array}{l}\text { This information is compiled by the Energy } \\
\text { Information Administration as part of the CBECS } \\
\text { analysis and more information is available on their } \\
\text { website } \\
\text { (http://www.eia.doe.gov/emeu/cbecs/tech_end_use } \\
\text { html) } \\
\text { CEUS uses a simulation framework (DrCEUS Site } \\
\text { Processor) to post-process the survey data and } \\
\text { generate cooking energy end use. (For more } \\
\text { information, please refer to CEUS report Appendix } \\
\text { H.) }\end{array}$ & $\begin{array}{l}\text { Reference was } \\
\text { added to the } \\
\text { main text }\end{array}$ \\
\hline 2 & $\begin{array}{l}\text { Baseline } \\
\text { Cooking } \\
\text { Energy } \\
\text { Use }\end{array}$ & $\begin{array}{l}\text { Section 3.3.1 Estimating Cooking Energy Use } \\
\text { Table 3.9 EUI Data for QSRs With A Building } \\
\text { Area of } 2000 \text { to } 2500 \mathrm{ft}^{2}\end{array}$ & $\begin{array}{l}\text { I'm noticing the difference } \\
\text { in HVAC. Where were } \\
\text { these located? }\end{array}$ & $\begin{array}{l}\text { These are both located in Canada. QSR } 2 \text { was } \\
\text { Calgary, Alberta, and QSR } 3 \text { was Vancouver, } \\
\text { British Colombia. Very similar to comparing } \\
\text { Seattle, Washington, with Billings, Montana. The } \\
\text { breakdowns were calculated, but the EUIs were } \\
\text { based on actual energy use. }\end{array}$ & $\begin{array}{l}\text { Report was } \\
\text { edited. }\end{array}$ \\
\hline 3 & $\begin{array}{l}\text { Baseline } \\
\text { Cooking } \\
\text { Energy } \\
\text { Use }\end{array}$ & $\begin{array}{l}\text { Section 3.3.1 Estimating Cooking Energy Use } \\
\text { "Proprietary data collected on over } 650 \text { QSRs was } \\
\text { evaluated with regard to square footage and the } \\
\text { results are presented in Table } 3.10 \text { as well as } \\
\text { graphically in Figure 3.4. It can be observed that the } \\
\text { total building EUI varies greatly with the floor area } \\
\text { of the building and it is expected that the cooking } \\
\text { EUIs follow the same pattern because most QSRs } \\
\text { have a standardized cooking platform which does } \\
\text { not significantly vary from store to store." }\end{array}$ & $\begin{array}{l}\text { Same pattern as what? Do } \\
\text { they vary a lot with the } \\
\text { floor area, or do they not } \\
\text { vary much from store to } \\
\text { store? I can't tell from the } \\
\text { wording of the sentence. }\end{array}$ & $\begin{array}{l}\text { The cooking EUI's vary significantly from store to } \\
\text { store, which can be a function of either the } \\
\text { difference in floor area or a difference in the } \\
\text { cooking platform. }\end{array}$ & $\begin{array}{l}\text { Report was } \\
\text { edited }\end{array}$ \\
\hline 4 & $\begin{array}{l}\text { Cooking } \\
\text { Appliance }\end{array}$ & $\begin{array}{l}\text { Section 3.3.2 Cooking Appliance } \\
\text { "The operational state (idle, light-load, medium- } \\
\text { load, etc.) was defined for each appliance as a } \\
\text { function of the building occupancy with the general } \\
\text { trend being that more appliances were used to cook } \\
\text { the food when more occupants were in the building." }\end{array}$ & $\begin{array}{l}\text { This may not necessarily } \\
\text { track energy use if a large } \\
\text { portion of the sales are } \\
\text { from the drive through. }\end{array}$ & $\begin{array}{l}\text { This is an excellent observation. The report had } \\
\text { stated that the occupancy was "building" occupants } \\
\text { when it is actually the total number of customers } \\
\text { either inside the restaurant or being served through } \\
\text { the drive-through. }\end{array}$ & $\begin{array}{l}\text { Report was } \\
\text { edited. }\end{array}$ \\
\hline
\end{tabular}




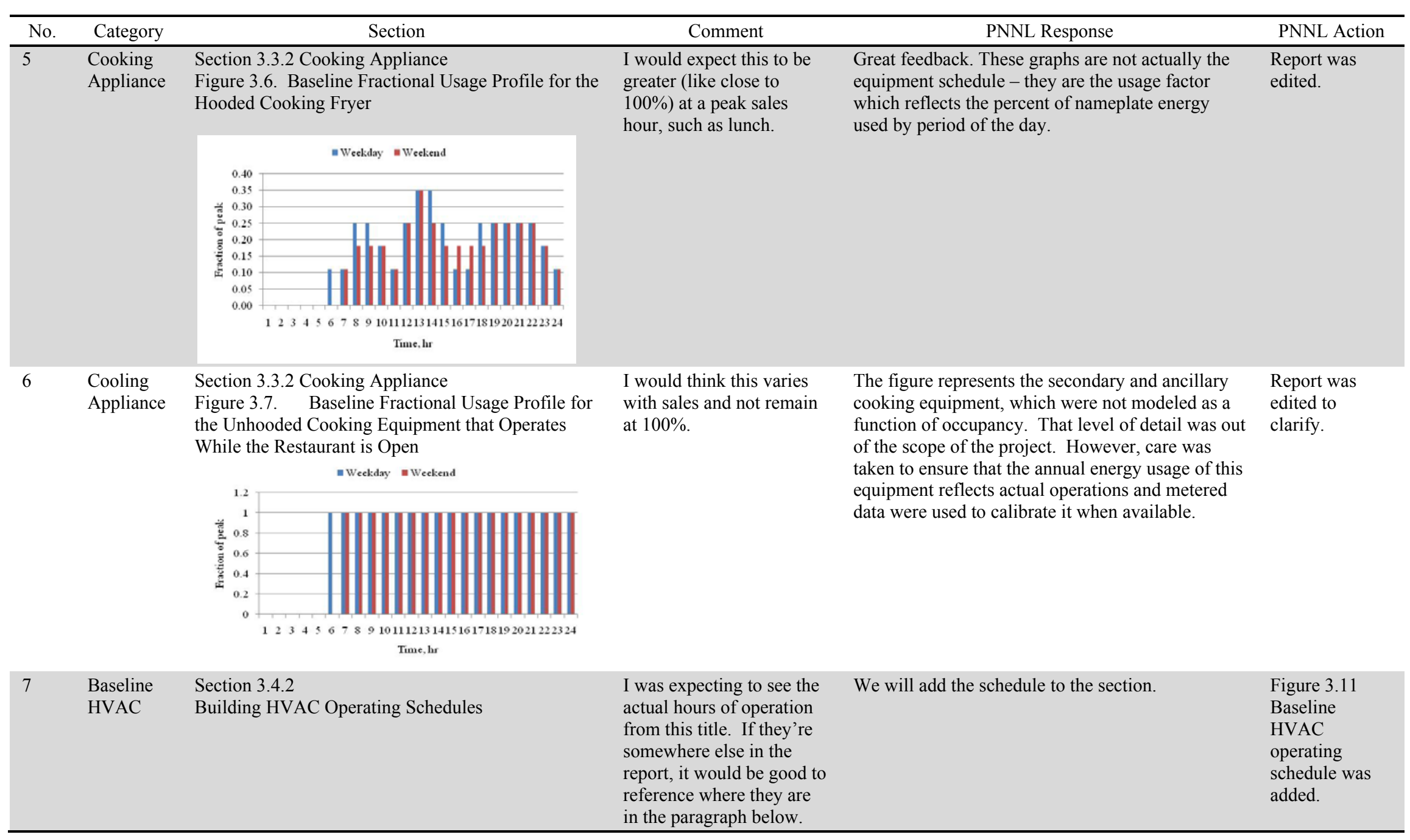




\begin{tabular}{|c|c|c|c|c|c|}
\hline No. & Category & Section & Comment & PNNL Response & PNNL Action \\
\hline 8 & $\begin{array}{l}\text { Baseline } \\
\text { HVAC }\end{array}$ & Section 3.4.7 Economizer Use & $\begin{array}{l}\text { I'll be interested to see } \\
\text { how this turns out. It } \\
\text { seems to me like QSRs } \\
\text { don't have any extra } \\
\text { reason to complain about } \\
\text { maintenance of an } \\
\text { economizer than any other } \\
\text { building type. }\end{array}$ & We will add an economizer to the baseline model. & $\begin{array}{l}\text { Economizers } \\
\text { were added to } \\
\text { the baseline } \\
\text { buildings per } \\
\text { the Standard } \\
90.1-2004 \\
\text { requirement. }\end{array}$ \\
\hline 9 & EEMs & $\begin{array}{l}\text { Chapter } 4.0 \text { Advanced Low-Energy Use Building } \\
\text { Models }\end{array}$ & $\begin{array}{l}\text { I would recommend a } \\
\text { process to allow quick } \\
\text { amending of these } \\
\text { standards so if we } \\
\text { encounter a measure that } \\
\text { doesn't work or causes } \\
\text { other issues, that measure } \\
\text { can be quickly amended. }\end{array}$ & $\begin{array}{l}\text { We will provide sections to present the energy } \\
\text { saving results for different group of EEMs (i.e., } \\
\text { envelope, lighting, cooking appliances, and } \\
\text { mechanical systems). The associated cost } \\
\text { effectiveness analysis results would be helpful for } \\
\text { designers or restaurant owners to select the most } \\
\text { cost effective measure groups. }\end{array}$ & $\begin{array}{l}\text { Sections } 5.4 \\
\text { and } 6.3 \text { were } \\
\text { added. }\end{array}$ \\
\hline 10 & EEMs & $\begin{array}{l}\text { Chapter } 4.0 \text { Advanced Low-Energy Use Building } \\
\text { Models } \\
\text { HVAC Measures }\end{array}$ & $\begin{array}{l}\text { Suggest to include } \\
\text { economizer }\end{array}$ & $\begin{array}{l}\text { Thank you for the feedback. We will include the } \\
\text { air-side economizer in both baseline models and } \\
\text { the advanced low-energy design models. For the } \\
\text { baseline model, an economizer will be in place to } \\
\text { meet the minimum requirement by Standard 90.1- } \\
\text { 2004. Further, we will expand the application of } \\
\text { economizer in the advanced cases to meet much } \\
\text { more stringent requirement from other AEDG } \\
\text { guides and newly developed Standard90.1-2010. }\end{array}$ & $\begin{array}{l}\text { Modified the } \\
\text { analysis and } \\
\text { report by } \\
\text { adding } \\
\text { economizer in } \\
\text { the models per } \\
\text { requirements in } \\
\text { Addendum CY } \\
\text { to Standard } \\
90.12007 \text {. }\end{array}$ \\
\hline 11 & EEMs & $\begin{array}{l}\text { Chapter } 4.0 \text { Advanced Low-Energy Use Building } \\
\text { Models }\end{array}$ & $\begin{array}{l}\text { Will there be any } \\
\text { "Weighting" of these } \\
\text { measures? For example, } \\
\text { an increase in HVAC } \\
\text { efficiency adds a greater } \\
\text { value than an increase in } \\
\text { envelope efficiency. }\end{array}$ & $\begin{array}{l}\text { We will provide sections to present the energy } \\
\text { saving results for different group of EEMs (i.e., } \\
\text { envelope, lighting, cooking appliances, and } \\
\text { mechanical systems). The associated cost } \\
\text { effectiveness analysis results would be helpful for } \\
\text { designers or restaurant owners to select the most } \\
\text { cost effective measure groups. }\end{array}$ & $\begin{array}{l}\text { Sections } 5.4 \\
\text { and } 6.3 \text { were } \\
\text { added. }\end{array}$ \\
\hline
\end{tabular}




\begin{tabular}{|c|c|c|c|c|c|}
\hline No. & Category & Section & Comment & PNNL Response & PNNL Action \\
\hline 12 & EEMs & Section 4.1.2 High-Performance Windows & $\begin{array}{l}\text { Consider that retail spaces } \\
\text { need customer visibility; } \\
\text { so while heavily tinted } \\
\text { glass can save energy, it } \\
\text { also prevents customers } \\
\text { from looking into the } \\
\text { restaurant and seeing if it } \\
\text { is open or full of people. }\end{array}$ & $\begin{array}{l}\text { Great feedback. We recognize that this is } \\
\text { imposing a marketing bias; however, some QSRs } \\
\text { have implemented this as a viable strategy within } \\
\text { their LEED designs. The daylighting windows in } \\
\text { the advanced buildings are the same as the view } \\
\text { windows. The U-factor, SHGC, and VT values } \\
\text { based on the requirements of Addendum BB to } \\
\text { Standard 90.1-2007. }\end{array}$ & No action \\
\hline 13 & EEMs & $\begin{array}{l}\text { Section } 4.1 .4 \text { Vestibule } \\
\text { "...requires the quick service restaurant buildings } \\
\text { in } 3 \text { through } 8 \text { to have vestibule to achieve energy } \\
\text { saving by reducing the door infiltration." }\end{array}$ & Why not all zones? & $\begin{array}{l}\text { The vestibule EEM was removed from the } \\
\text { advanced model. Although there is a change of } \\
\text { vestibule requirements from Standard } 90.1-2004 \text { to } \\
\text { Addendum I to Standard } 90.1-2007 \text {, it is believed } \\
\text { that a QSR vestibule in a cold climate is already a } \\
\text { common design practice. No saving credit is taken } \\
\text { from it. }\end{array}$ & $\begin{array}{l}\text { The vestibule } \\
\text { EEM was } \\
\text { removed } \\
\text { because a } \\
\text { vestibule in a } \\
\text { cold climate is } \\
\text { considered to } \\
\text { be a common } \\
\text { design practice }\end{array}$ \\
\hline 14 & EEMs & $\begin{array}{l}\text { Section 4.2.1.4 Daylight Harvesting- Side Lighting } \\
\text { "... the daylighting dimming control" }\end{array}$ & $\begin{array}{l}\text { As a retail space, we also } \\
\text { rely on accent lighting, } \\
\text { which when dimmed will } \\
\text { affect (possibly } \\
\text { negatively) the ambience } \\
\text { of our dining area. }\end{array}$ & $\begin{array}{l}\text { The daylight dimming control only affects general } \\
\text { area lighting. Accent lighting is not considered to } \\
\text { be dimmable. As a result, only } 33 \% \text { of the lights } \\
\text { in the dining area will be dimmed when sufficient } \\
\text { natural light is available. }\end{array}$ & No action \\
\hline 15 & EEMs & Section 4.3 Commercial Kitchen & $\begin{array}{l}\text { A measure should be } \\
\text { included that provides a } \\
\text { credit for using appliances } \\
\text { that can automatically } \\
\text { modulate their power use } \\
\text { based on throughput. } \\
\text { While this may not be } \\
\text { currently available, it will } \\
\text { in the near future. }\end{array}$ & $\begin{array}{l}\text { The modeling effectively achieves this goal by } \\
\text { modeling the appliances beneath the hoods as } \\
\text { either being in idle, light, medium, or heavy-duty } \\
\text { operation, thereby modulating the appliance energy } \\
\text { consumption as a function of the building and } \\
\text { drive-through customers. }\end{array}$ & No action \\
\hline 16 & EEMs & $\begin{array}{l}\text { Section } 4.4 .2 \text { Commercial Ventilation System } \\
\text { "Not only the exhaust fan flow rate can be reduced } \\
\text { in the advance model, a demand controlled exhaust } \\
\text { fan flow rate as a function of hooded appliance } \\
\text { usage can also improve the energy efficiency of the } \\
\text { advanced QSR building. Based on the operation } \\
\text { schedule of the hooded cooking appliances, a } \\
\text { fractional schedule of the kitchen exhaust flow rate } \\
\text { is developed as shown in Figure 4.7." }\end{array}$ & $\begin{array}{l}\text { Is the demand-control } \\
\text { exhaust applicable to low- } \\
\text { proximity hoods also? } \\
\text { Canopy hoods I can } \\
\text { understand, but low- } \\
\text { proximity hoods may be a } \\
\text { challenge. }\end{array}$ & $\begin{array}{l}\text { The economics of demand control for proximity } \\
\text { hoods is much less attractive because they operate } \\
\text { at relatively low exhaust airflows already, but it is } \\
\text { being tried out in a couple of LEED QSRs. The } \\
\text { jury is out, but for projects pushing the envelope, } \\
\text { there is an energy saving benefit. If an intelligent } \\
\text { appliance could directly communicate with the } \\
\text { exhaust fan, then the DVC cost could drop } \\
\text { dramatically (not optics or temp sensor required). }\end{array}$ & No action \\
\hline
\end{tabular}





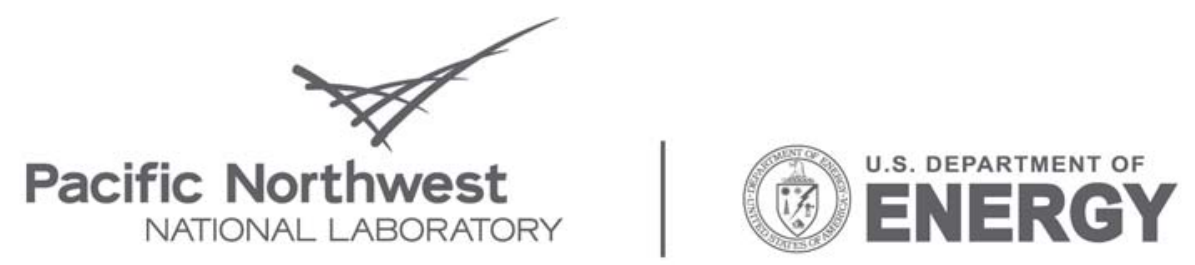

Proudly Operated by Battelle Since 1965

902 Battelle Boulevard

P.O. Box 999

Richland, WA 99352

1-888-375-PNNL (7665)

www.pnl.gov 